\title{
A Hydrostratigraphic System for Modeling Groundwater Flow and Radionuclide Migration at the Corrective Action Unit Scale, Nevada Test Site and Surrounding Areas, Clark, Lincoln, and Nye Counties, Nevada
}

January 2009

Prepared for:

U.S. Department of Energy

National Nuclear Security Administration

Nevada Site Office

\section{Prepared by:}

Lance B. Prothro, Sigmund L. Drellack, Jr., and Jennifer M. Mercadante

Underground Test Area and Boreholes Programs and Operations

Environmental Restoration

National Security Technologies, LLC

Las Vegas, Nevada 


\section{DISCLAIMER STATEMENT}

Reference herein to any specific commercial product, process, or service by trade name, trademark, manufacturer, or otherwise, does not necessarily constitute or imply its endorsement, recommendation, or favoring by the U.S. Government or any agency thereof or its contractors or subcontractors.

\section{AVAILABILITY STATEMENT}

Available to the public, in paper from-

U.S. Department of Commerce

National Technical Information Service

5285 Port Royal Road

Springfield, VA 22161-0002

Telephone: 800.553.6847

Fax: 703.605.6900

E-mail: orders@ntis.gov

Online ordering: http://www.ntis.gov/ordering.htm

Available electronically at http://www.osti.gov/bridge

Available for a processing fee to U.S. Department of Energy and its contractors, in paper, from-

U.S. Department of Energy

Office of Scientific and Technical Information

P.O. Box 62

Oak Ridge, TN, 37831-0062

Telephone: 865.576.8401

Fax: 865.576.5728

E-mail: reports@adonis.osti.gov 


\title{
A Hydrostratigraphic System for Modeling Groundwater Flow and Radionuclide Migration at the Corrective Action Unit Scale, Nevada Test Site and Surrounding Areas, Clark, Lincoln, and Nye Counties, Nevada
}

\author{
Prepared for: \\ U.S. Department of Energy \\ National Nuclear Security Administration \\ Nevada Site Office \\ Las Vegas, Nevada
}

Prepared by:

Lance B. Prothro, Sigmund L. Drellack, Jr., and Jennifer M. Mercadante

Underground Test Area and Boreholes Programs and Operations National Security Technologies, LLC

Las Vegas, Nevada

January 2009 
This page intentionally left blank. 


\section{ABSTRACT}

Underground Test Area (UGTA) corrective action unit (CAU) groundwater flow and contaminant transport models of the Nevada Test Site (NTS) and vicinity are built upon hydrostratigraphic framework models (HFMs) that utilize the hydrostratigraphic unit (HSU) as the fundamental modeling component. The delineation and three-dimensional (3-D) modeling of HSUs within the highly complex geologic terrain that is the NTS requires a hydrostratigraphic system that is internally consistent, yet flexible enough to account for overlapping model areas, varied geologic terrain, and the development of multiple alternative HFMs. The UGTA CAUscale hydrostratigraphic system builds on more than 50 years of geologic and hydrologic work in the NTS region. It includes 76 HSUs developed from nearly 300 stratigraphic units that span more than 570 million years of geologic time, and includes rock units as diverse as marine carbonate and siliciclastic rocks, granitic intrusives, rhyolitic lavas and ash-flow tuffs, and alluvial valley-fill deposits.

The UGTA CAU-scale hydrostratigraphic system uses a geology-based approach and two-level classification scheme. The first, or lowest, level of the hydrostratigraphic system is the hydrogeologic unit (HGU). Rocks in a model area are first classified as one of ten HGUs based on the rock's ability to transmit groundwater (i.e., nature of their porosity and permeability), which at the NTS is mainly a function of the rock's primary lithology, type and degree of postdepositional alteration, and propensity to fracture.

The second, or highest, level within the UGTA CAU-scale hydrostratigraphic system is the HSU, which is the fundamental mapping/modeling unit within UGTA CAU-scale HFMs. HSUs are 3-D bodies that are represented in the finite element mesh for the UGTA groundwater modeling process. HSUs are defined systematically by stratigraphically organizing HGUs of similar character into larger HSUs designations. The careful integration of stratigraphic information in the development of HSUs is important to assure individual HSUs are internally consistent, correlatable, and mappable throughout all the model areas. 
This page intentionally left blank. 


\section{Table of Contents}

\begin{tabular}{|c|c|}
\hline \multicolumn{2}{|l|}{\begin{tabular}{|l|} 
Abstract \\
\end{tabular}} \\
\hline List of Figures & vii \\
\hline List of Tables & \\
\hline List of Plates & \\
\hline
\end{tabular}

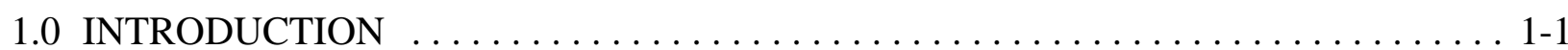

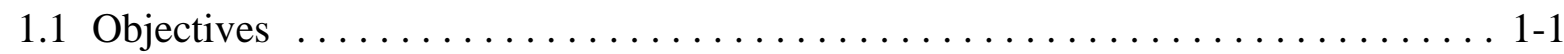

1.2 Geologic Setting . . . . . . . . . . . . . . . . . . . . . . . . . . . .

1.3 Hydrologic Setting . . . . . . . . . . . . . . . . . . . . . . . . . . . . 1-8

1.4 UGTA Hydrostratigraphic Framework Models $\ldots \ldots \ldots \ldots \ldots \ldots \ldots \ldots \ldots$ 1-10

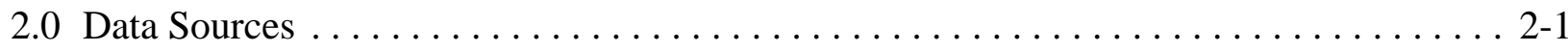

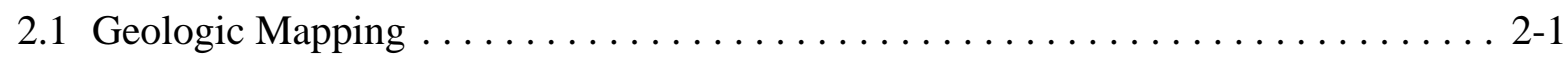

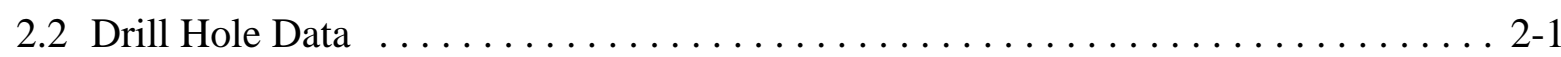

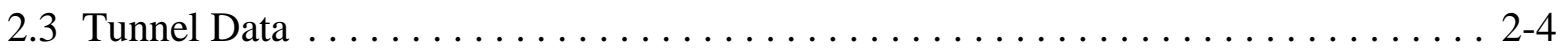

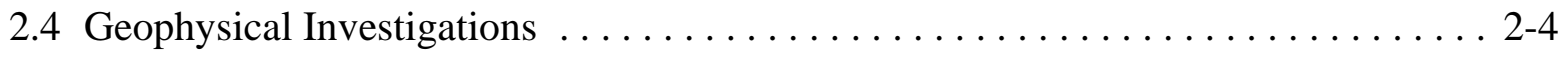

3.0 The UGTA CAU-Scale Hydrostratigraphic System $\ldots \ldots \ldots \ldots \ldots \ldots \ldots \ldots$ 3-1

3.1 Hydrogeologic Units $\ldots \ldots \ldots \ldots \ldots \ldots \ldots \ldots \ldots \ldots \ldots \ldots \ldots \ldots \ldots \ldots \ldots \ldots .2$

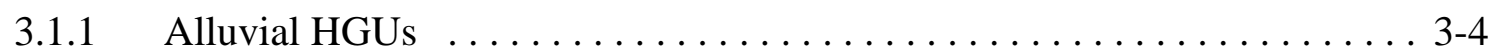

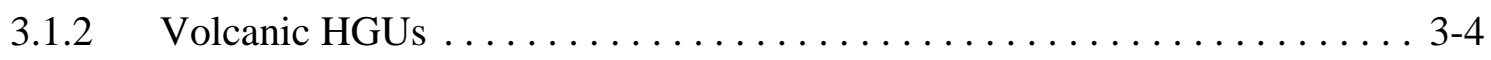

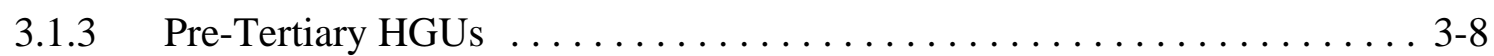

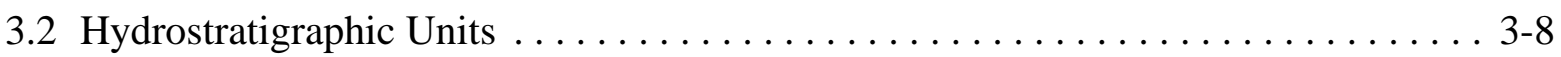

3.2.1 Methodology for Delineating Hydrostratigraphic Units . . . . . . . . . 3-20

3.2.2 Hydrostratigraphic Complexities . . . . . . . . . . . . . . . . . . . . 3-25

3.2 .2 .1 Changes in Lithofacies $\ldots \ldots \ldots \ldots \ldots \ldots \ldots \ldots \ldots \ldots \ldots \ldots \ldots \ldots \ldots \ldots, 25$

3.2.2.2 $\quad$ Lateral Stratigraphic Terminations ...................... 3-27

$3.2 .2 .3 \quad$ Post-Depositional Alteration . . . . . . . . . . . . . . . . . . . . . 3-31

$3.2 .2 .4 \quad$ Thrust Plates . . . . . . . . . . . . . . . . . . . . . . . . . . . 3-34

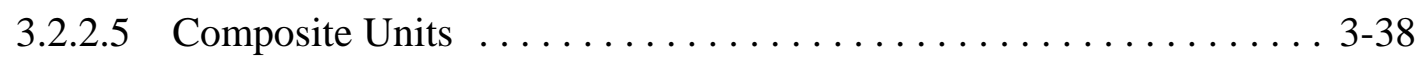




\section{Table of Contents, continued}

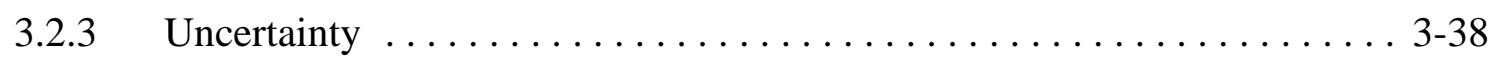

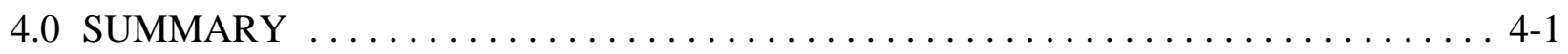

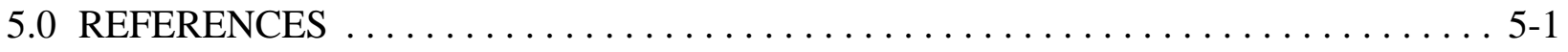

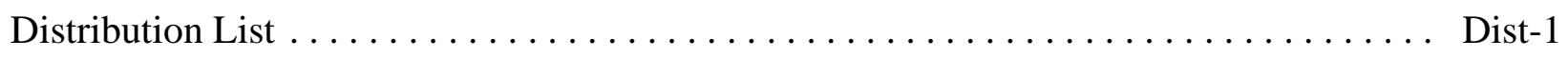

Appendix A Hydrostratigraphic Units of UGTA CAU-Scale Hydrostratigraphic Framework Models

Appendix B Examples of HSU Delineation in UGTA Wells 


\section{List of Figures}

Number

Title

Page

1-1 Map Showing Locations of All UGTA HFM Areas . . . . . . . . . . . . . 1-2

1-2 Color Relief Map Showing Locations of the Basin and Range Physiographic and Great Basin Hydrographic Provinces . . . . . . . . . . . . . . . . 1-4

1-3 Generalized Geologic Map of the Nevada Test Site Area . . . . . . . . . . . . . 1-6

1-4 Detailed Geologic Compilation Map of the Nevada Test Site Area . . . . . . . . . . 1-7

1-5 Groundwater Sub-Basins of the Nevada Test Site and Vicinity . . . . . . . . . . 1-9

1-6 Cut-Away View of the Yucca Flat-Climax Mine HFM . . . . . . . . . . . . . . 1-12

1-7 West-East Profile through the Pahute Mesa-Oasis Valley HFM . . . . . . . . . 1-13

2-1 Locations of Geologic Quadrangle Maps Covering the Nevada Test Site Area . . . . 2-2

2-2 Distribution of Boreholes on the Nevada Test Site and Surrounding Areas That Have Been Drilled or Utilized by DOE Activities . . . . . . . . . . . . . . 2-3

2-3 Generalized Geologic Map of the Rainier Mesa Area Showing Locations of Area 12 Tunnel Complexes in which Nuclear Tests were Conducted . . . . . . . . 2-5

2-4 Generalized Geologic Map of the Shoshone Mountain Area Showing Location

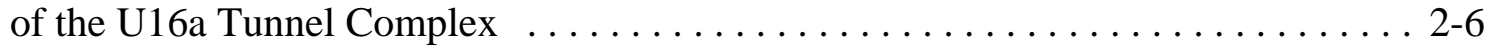

3-1 Photographs of Alluvium from the U1a Complex . . . . . . . . . . . . . 3-5

3-2 Photographs of Yucca Lake Playa . . . . . . . . . . . . . . . . . . 3-6

3-3 Exposure of Tuff Confining Unit Rocks in Area 12 . . . . . . . . . . . . . . . . 3-7

3-4 Exposure of Welded-Tuff Aquifer in Area $16 \ldots \ldots \ldots \ldots \ldots \ldots$. . . . . . . . . . .

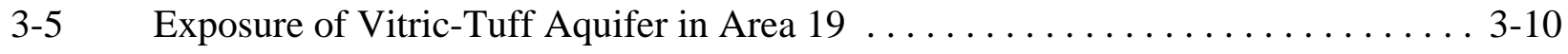

3-6 Close-up View of Lava-Flow Aquifer in Area 20 . . . . . . . . . . . . . . 3-11

3-7 Exposure of Clastic Confining Unit in Area $16 \ldots \ldots \ldots \ldots$. . . . . . . . . . 3-12

3-8 Photograph of Drill Core of Granite Confining Unit . . . . . . . . . . . . . . . . 3-13

3-9 Exposure of Carbonate Aquifer in the Halfpint Range, Area 3 . . . . . . . . . . 3-14

3-10 Illustration of the Delineation and Mapping of HSUs Based on Surface

Exposures and Geologic Quadrangle Maps . . . . . . . . . . . . . . . . . 3-22

3-11 Illustration of the Delineation of HSUs Based on Drill Hole Data . . . . . . . . . . 3-23

3-12 Schematic Cross Sections that Illustrate the Importance of Integrating Stratigraphic Information in the Correlation and Delineation of HSUs . . . . . . . 3-24

3-13 Simplified Schematic Cross Section through an Ash-Flow Tuff Showing Zones of Welding . . . . . . . . . . . . . . . . . . . . . . 3-26

3-14 Exposure of Ash-Flow Tuff Lithofacies in the Basal Portion of the Rainier Mesa Tuff, Pahute Mesa, Area $19 \ldots \ldots \ldots \ldots \ldots \ldots \ldots . \ldots \ldots$. . . . . . . . . . . . . . . . . . . .

3-15 Schematic West-East Cross Section across Yucca Flat Illustrating the Delineation of HSUs with Respect to Lithofacies within the Rainier Mesa Tuff . . 3-29 


\section{List of Figures, continued}

Number

Title

Page

3-16 Exposure of Welded Grouse Canyon Tuff Showing Lateral Pinch-Out of the Unit (Area 17) .................................. 30

3-17 Schematic Hydrostratigraphic Cross Section through Southern Yucca Flat Showing Relationships Among the TCUs and the Topopah Spring Aquifer ..... . 3-32

3-18 Schematic Hydrostratigraphic Cross Section through Northern Half of the Rainier Mesa-Shoshone Mountain Model Area Showing the Relationships Among the TCU and WTA Hydrostratigraphic Units $\ldots . \ldots \ldots \ldots . . . \ldots . . .33$

3-19 Stratigraphic Columns for Three Drill Holes in Yucca Flat Showing the Stratigraphic Variability in the Top of Zeolitization . . . . . . . . . . . . . . . 3-35

3-20 Photograph of Devonian Carbonate Emplaced of Mississippian Shale Along the Tongue Wash Fault, East Flank of Rainier Mesa . . . . . . . . . . . . . . 3-36

3-21 Schematic Northwest-Southeast Cross Section through the Eleana Range and Syncline Ridge Showing Thrust Fault Relationships . ............... 3-37

B-1 Graphical Presentation Showing Stratigraphy, Lithology, Alteration, Hydrogeologic Units, and Hydrostratigraphic Units for UGTA Well ER-2-1 . . . . B B-1

B-2 Graphical Presentation Showing Stratigraphy, Lithology, Alteration, Hydrogeologic Units, and Hydrostratigraphic Units for UGTA Well ER-3-1 . . . . . B-2

B-3 Graphical Presentation Showing Stratigraphy, Lithology, Alteration, Hydrogeologic Units, and Hydrostratigraphic Units for UGTA Well ER-3-2 . . . . B B-3

B-4 Graphical Presentation Showing Stratigraphy, Lithology, Alteration, Hydrogeologic Units, and Hydrostratigraphic Units for UGTA Well ER-5-3 . . . . . B-4

B-5 Graphical Presentation Showing Stratigraphy, Lithology, Alteration, Hydrogeologic Units, and Hydrostratigraphic Units for UGTA Well ER-5-4 . . . . . B-5

B-6 Graphical Presentation Showing Stratigraphy, Lithology, Alteration, Hydrogeologic Units, and Hydrostratigraphic Units for UGTA Well ER-6-1 . . . . . B-6

B-7 Graphical Presentation Showing Stratigraphy, Lithology, Alteration, Hydrogeologic Units, and Hydrostratigraphic Units for UGTA Well ER-6-2 . . . . B B-7

B-8 Graphical Presentation Showing Stratigraphy, Lithology, Alteration, Hydrogeologic Units, and Hydrostratigraphic Units for UGTA Well ER-7-1 . . . . B B-8

B-9 Graphical Presentation Showing Stratigraphy, Lithology, Alteration, Hydrogeologic Units, and Hydrostratigraphic Units for UGTA Well ER-8-1 . . . . . B-9

B-10 Graphical Presentation Showing Stratigraphy, Lithology, Alteration, Hydrogeologic Units, and Hydrostratigraphic Units for UGTA Well ER-12-1 . . . B-10

B-11 Graphical Presentation Showing Stratigraphy, Lithology, Alteration, Hydrogeologic Units, and Hydrostratigraphic Units for UGTA Well ER-12-2 . . . B-11

B-12 Graphical Presentation Showing Stratigraphy, Lithology, Alteration, Hydrogeologic Units, and Hydrostratigraphic Units for UGTA Well ER-12-3 . . . B-12 


\section{List of Figures, continued}

Number

Title

Page

B-13 Graphical Presentation Showing Stratigraphy, Lithology, Alteration, Hydrogeologic Units, and Hydrostratigraphic Units for UGTA Well ER-12-4 . . . B-13

B-14 Graphical Presentation Showing Stratigraphy, Lithology, Alteration, Hydrogeologic Units, and Hydrostratigraphic Units for UGTA Well ER-16-1 . . . B-14

B-15 Graphical Presentation Showing Stratigraphy, Lithology, Alteration, Hydrogeologic Units, and Hydrostratigraphic Units for UGTA Well ER-18-2 . . . B-15

B-16 Graphical Presentation Showing Stratigraphy, Lithology, Alteration, Hydrogeologic Units, and Hydrostratigraphic Units for UGTA Well ER-19-1 . . . B-16

B-17 Graphical Presentation Showing Stratigraphy, Lithology, Alteration, Hydrogeologic Units, and Hydrostratigraphic Units for UGTA Well ER-20-1 . . . B-17

B-18 Graphical Presentation Showing Stratigraphy, Lithology, Alteration, Hydrogeologic Units, and Hydrostratigraphic Units for UGTA

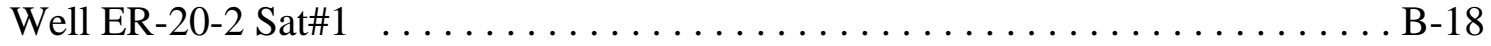

B-19 Graphical Presentation Showing Stratigraphy, Lithology, Alteration, Hydrogeologic Units, and Hydrostratigraphic Units for UGTA Well ER-20-5 . . . B-19

B-20 Graphical Presentation Showing Stratigraphy, Lithology, Alteration, Hydrogeologic Units, and Hydrostratigraphic Units for UGTA Well ER-20-6 . . . B-20

B-21 Graphical Presentation Showing Stratigraphy, Lithology, Alteration, Hydrogeologic Units, and Hydrostratigraphic Units for UGTA Well ER-30-1 . . . B-21

B-22 Graphical Presentation Showing Stratigraphy, Lithology, Alteration, Hydrogeologic Units, and Hydrostratigraphic Units for UGTA Well ER-EC-1 . . B-22

B-23 Graphical Presentation Showing Stratigraphy, Lithology, Alteration, Hydrogeologic Units, and Hydrostratigraphic Units for UGTA Well ER-EC-2A .. B-23

B-24 Graphical Presentation Showing Stratigraphy, Lithology, Alteration, Hydrogeologic Units, and Hydrostratigraphic Units for UGTA Well ER-EC-4 . . B-24

B-25 Graphical Presentation Showing Stratigraphy, Lithology, Alteration, Hydrogeologic Units, and Hydrostratigraphic Units for UGTA Well ER-EC-5 .. B-25

B-26 Graphical Presentation Showing Stratigraphy, Lithology, Alteration, Hydrogeologic Units, and Hydrostratigraphic Units for UGTA Well ER-EC-6 . . B-26

B-27 Graphical Presentation Showing Stratigraphy, Lithology, Alteration, Hydrogeologic Units, and Hydrostratigraphic Units for UGTA Well ER-EC-7 . . B-27

B-28 Graphical Presentation Showing Stratigraphy, Lithology, Alteration, Hydrogeologic Units, and Hydrostratigraphic Units for UGTA Well ER-EC-8 . . B-28

P-1 Generalized Geologic Map Showing the Regions Represented by the Hydrostratigraphic Columns in Plate $2 \ldots \ldots \ldots$ Follows Plate 2 
This page intentionally left blank. 


\section{List of Tables}

Number

3-1 Hydrogeologic Units of the Nevada Test Site $\ldots \ldots \ldots \ldots \ldots \ldots \ldots \ldots \ldots$. . . . . .

3-2 Correlation of Hydrostratigraphic Units Among the Four UGTA HFMs at the Nevada Test Site . . . . . . . . . . . . . . . . . . . . . 3-16

A-1 Hydrostratigraphic Units of UGTA CAU-Scale Hydrostratigraphic

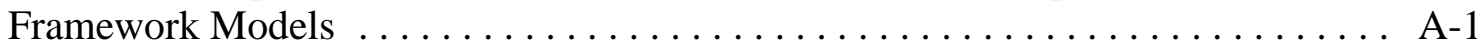


This page intentionally left blank. 


\section{List of Plates}

Plate 1 Stratigraphic Units of the Nevada Test Site Region

Plate 2 Correlation of Stratigraphic and Hydrostratigraphic Units for the Four UGTA Hydrostratigraphic Framework Model Areas 
This page intentionally left blank. 


\section{List of Acronyms and Abbreviations}

3-D three-dimensional

AA alluvial aquifer

BN Bechtel Nevada

CA carbonate aquifer

CAU corrective action unit

CHZCM Calico Hills zeolitic composite unit

CCU clastic confining unit

CM composite unit

DOE/NV U.S. Department of Energy, Nevada Operations Office

$\mathrm{ft} \quad$ foot (feet)

GCU granite confining unit

HFM hydrostratigraphic framework model

HGU hydrogeologic unit

HSU hydrostratigraphic unit

IICU intra-caldera intrusive confining unit

IT IT Corporation

LCA lower carbonate aquifer

LCA3 lower carbonate aquifer-thrust plate

LCA3-1 lower carbonate aquifer-thrust plate-1

LCCU lower clastic confining unit

LCCU1 lower clastic confining unit 1-thrust plate

LCCU2 lower clastic confining unit 2-thrust plate

LFA lava-flow aquifer

LTCU lower tuff confining unit

m meter(s)

MT magnetotelluric

NNSA/NSO U.S. Department of Energy, National Nuclear Security Administration, Nevada Site Office

NSTec National Security Technologies, LLC

NTS Nevada Test Site

OSBCU Oak Spring Butte confining unit

PCU playa confining unit

PM-OV Pahute Mesa-Oasis Valley

RM-SM Rainier Mesa-Shoshone Mountain

TCU tuff confining unit 


\section{List of Acronyms and Abbreviations, continued}

TMCM Timber Mountain composite unit

TM-LVTA Timber Mountain lower vitric-tuff aquifer

TM-WTA Timber Mountain welded-tuff aquifer

TSA Topopah Spring aquifer

UCCU upper clastic confining unit

UCCU1 upper clastic confining unit-thrust plate

UGTA Underground Test Area

USGS U.S. Geological Survey

VTA vitric-tuff aquifer

WTA welded-tuff aquifer

WTP Weapons Testing Program

YF-CM Yucca Flat-Climax Mine 


\subsection{INTRODUCTION}

The Environmental Restoration Project of the U.S. Department of Energy, National Nuclear Security Administration Nevada Site Office (NNSA/NSO) initiated the Underground Test Area (UGTA) Sub-Project to investigate the extent of groundwater contamination at the Nevada Test Site (NTS) and surrounding areas due to past underground nuclear testing. The UGTA investigation focuses on modeling the geology and hydrology of the NTS to estimate the direction and rate at which contaminants are transported by groundwater flow. A crucial step in this investigation was the construction of three-dimensional (3-D) hydrostratigraphic framework models (HFMs), one for each of the former underground nuclear testing areas, which are geographically organized into four corrective action units (CAUs) (Figure 1-1). These models are used to develop groundwater flow and contaminant transport models for each of the CAUs. The construction of HFMs required the development of a hydrostratigraphic system that organized rock units within the model area into hydrostratigraphic units (HSUs) according to their water-bearing qualities and in such a way that they could be accurately depicted in three dimensions within the HFMs.

HFMs for all four UGTA CAUs have been constructed, and the HSUs delineated for each model area now form a single CAU-scale hydrostratigraphic system for the entire NTS and vicinity. This system provides a consistent yet flexible framework for defining and modeling HSUs at the NTS and in surrounding areas. The system builds on more than 50 years of geologic and hydrologic work in the NTS region. It includes 76 HSUs developed from nearly 300 stratigraphic units (Warren et al., 2003) that span more than 500 million years of geologic time, and includes rock units as diverse as marine carbonate and siliciclastic rocks, granitic intrusives, rhyolitic lavas and ash-flow tuffs, and alluvial valley-fill deposits.

\subsection{Objectives}

The purpose of the UGTA CAU-scale hydrostratigraphic system is to provide a systematic and consistent method for organizing stratigraphic rock units in the NTS area into HSUs based on similar groundwater flow properties. Because HSUs are the building blocks for the HFMs on which flow and transport models are built, understanding the hydrostratigraphic system on which HSUs are based is critical for proper grid and mesh development, flow and transport parameterization, evaluation of model results, and model review. Thus, the objective of this report is to provide UGTA participants, including project scientists and modelers, peer reviewers, and stakeholders, a comprehensive overview of the CAU-scale hydrostratigraphic 


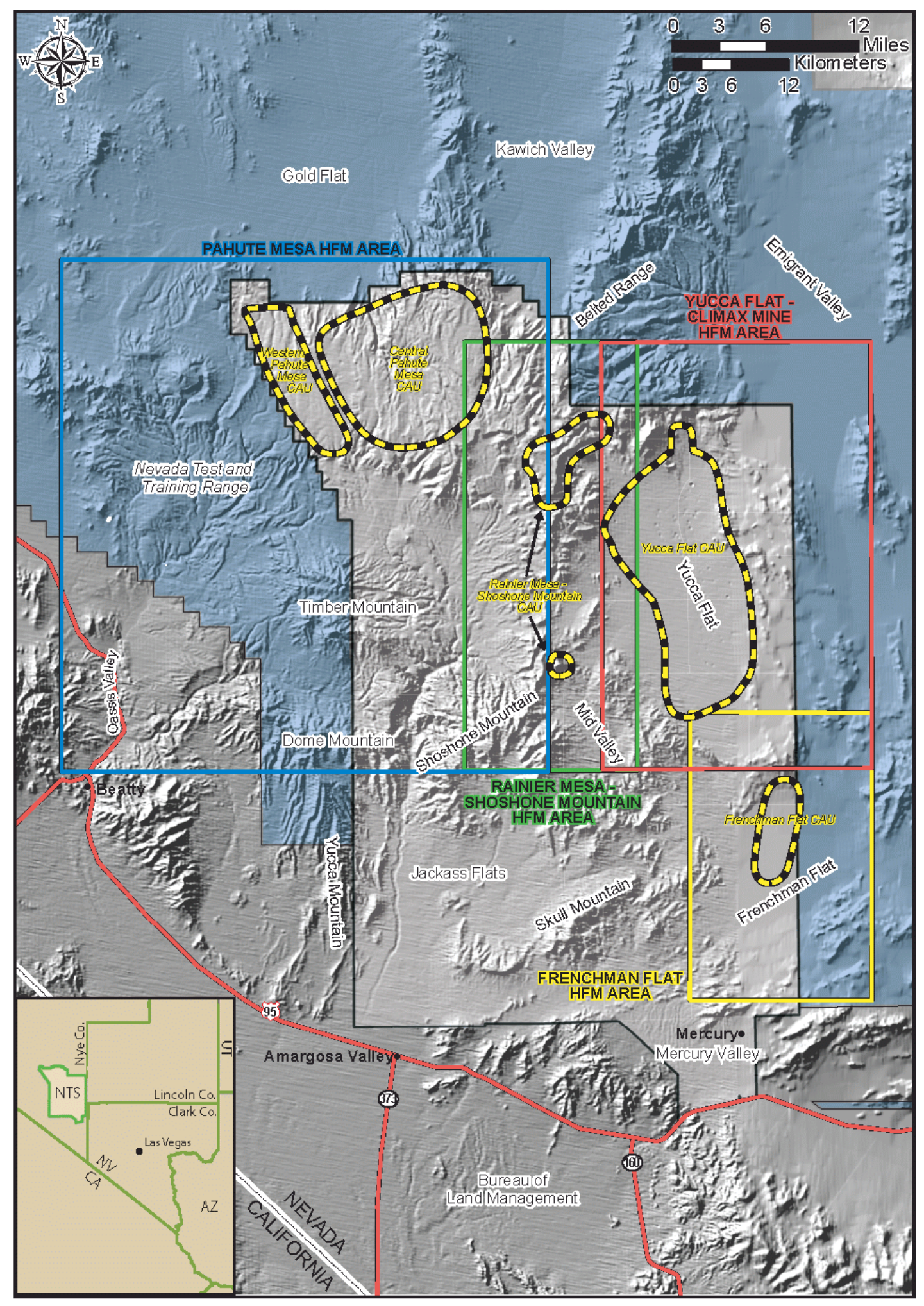

Figure 1-1

Map Showing Locations of All UGTA HFM Areas 
system that has previously been described only in the context of each individual HFM. The report is also intended to be a general reference resource for the hydrostratigraphic system and

units utilized in the HFMs. More detailed information on the HSUs can be found in the HFM documentation reports for each CAU (Bechtel Nevada [BN], 2002; 2005; 2006; National Security Technologies, LLC [NSTec], 2007).

It should be noted that the UGTA Sub-Project is ongoing, and that new HSUs may be developed in the future in response to new data and modeling requirements. Thus, the HSUs described in this report are those developed at the time of publication, which generally coincides with the completion of Phase I activities. It is likely that new HSUs will be developed as UGTA Phase II activities progress, and if so, they will be defined using the process of HSU development described here.

\subsection{Geologic Setting}

Geologically, the NTS area is very complex. The region includes diverse rock types that have been distributed by a variety of depositional processes, including extensive volcanic activity, followed by widespread alluvial deposition. It has undergone compressional and extensional structural events, causing extensive faulting and folding. This geologic complexity makes the delineation and 3-D correlation of HSUs very challenging. This section gives a brief overview of the geologic setting of the NTS region, and is intended to provide the reader with an appreciation of the diverse and complex geology of the NTS. More detailed discussions of the structure and stratigraphy of the UGTA CAU-scale model areas, including references, are found in their respective HFM documentation reports (BN, 2002; 2005; 2006; NSTec, 2007).

The NTS lies within the northern portion of the Basin and Range physiographic province, which is characterized by narrow, generally north-trending mountain ranges separated by valleys filled with alluvium (Figure 1-2). The oldest rocks in the NTS area are more than 200 million years old, and consist of Proterozoic and Paleozoic sedimentary and metasedimentary rocks of mostly marine origin. These rocks include limestone, dolomite, sandstone, siltstone, shale, quartzite, and argillite that are as much as 10,000 meters (m) (32,800 feet [ft]) thick in the NTS region (Cole and Cashman, 1999; Slate et al., 1999). This thick sedimentary section can be subdivided as follows: Upper Proterozoic to Middle Cambrian siliciclastic rocks, a thick sequence of Middle Cambrian to Upper Devonian carbonate rocks, Upper Devonian to Pennsylvanian siliciclastic rocks, and Pennsylvanian to Middle Permian carbonate rocks. More than 100 million years ago, these rocks were compressed by tectonic forces, resulting in the formation of folds and thrust faults (e.g., Belted Range and CP thrust faults) (Cole and Cashman, 1999). 


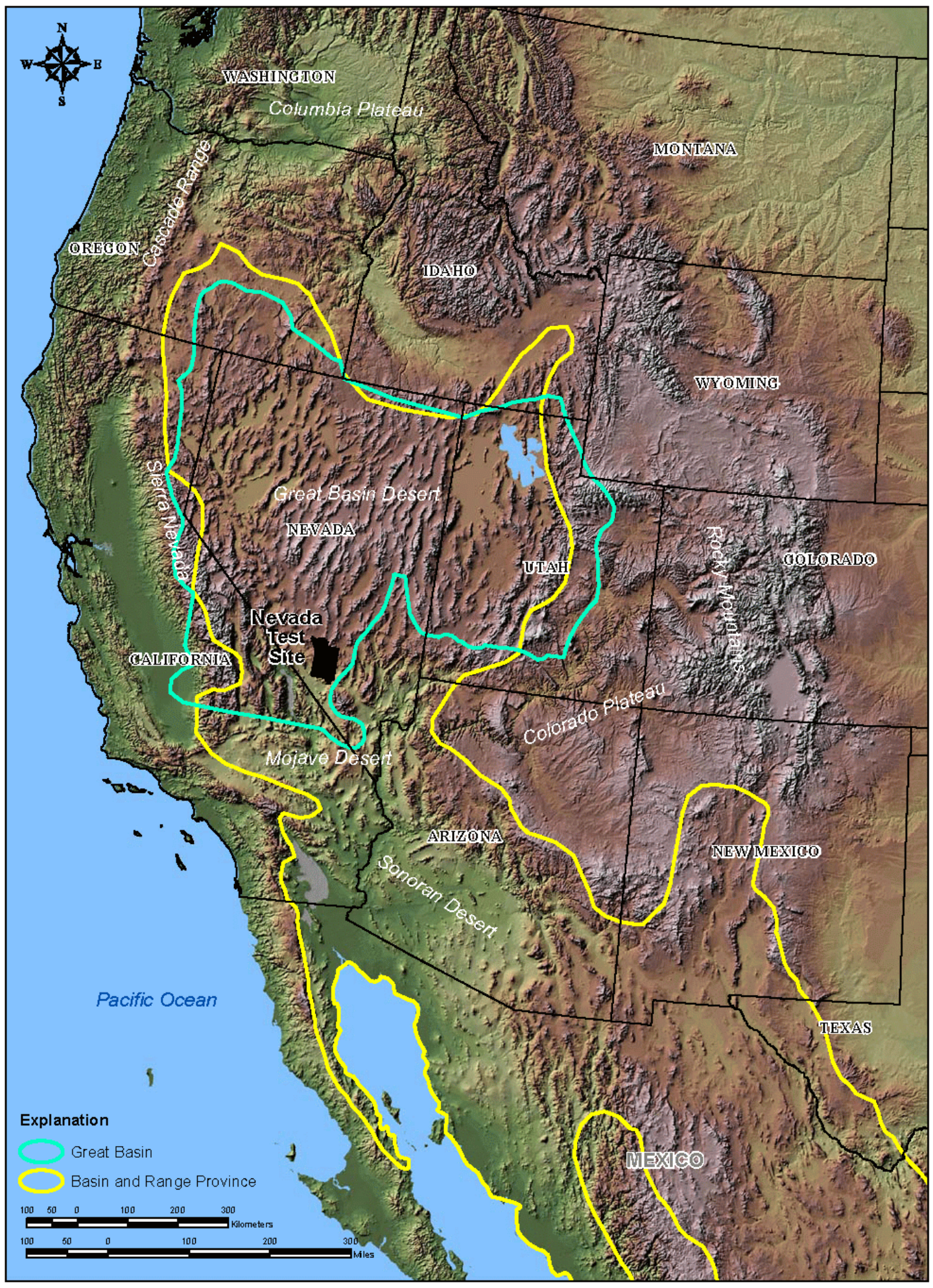

Figure 1-2

Color Relief Map Showing Locations of the Basin and Range Physiographic and Great Basin Hydrographic Provinces (Province boundaries from Fiero, 1986) 
During the Cretaceous period (about 100 million years ago), granitic bodies intruded these deformed rocks (Naeser and Maldonado, 1981). Two granitic bodies are exposed at the surface at the NTS: the Gold Meadows stock located just north of Rainier Mesa, and the Climax stock at the north end of Yucca Flat (Gibbons et al., 1963; Barnes et al., 1963). Except for Cretaceous granitic rocks, no rocks of Mesozoic- or lower Cenozoic-age are present at the NTS (Frizzell and Shulters, 1990).

The next youngest rocks at the NTS are relatively minor deposits of sedimentary and volcanic rocks of middle to upper Oligocene age (Frizzell and Shulters, 1990). During the middle Miocene, between approximately 15 and 9 million years ago, extensive eruptions of volcanic material resulted in the accumulation of a thick blanket of volcanic deposits across much of the NTS, and the formation of large calderas in the western and northwestern portions of the NTS and adjacent areas (Sawyer et al., 1994). Volcanic rocks include thick sequences of bedded ashand pumice-fall deposits and reworked tuff, laterally extensive sheets of welded ash-flow tuff, and intercalated occurrences of rhyolitic and basaltic lava. The thickness and extent of the volcanic rocks vary, partly because of the irregularity of the surface on which they were deposited, and partly because of the presence of topographic barriers and windows between the depositional areas and the source calderas to the west and northwest.

Extensional forces began to stretch and down-fault the rocks of the NTS region during the Miocene, resulting in the formation of an extensive system of normal faults (Sawyer et al., 1994). In the eastern and southern portions of the NTS, basins formed along large normal and strike-slip faults generally after the main phase of volcanic activity. These basins, which include Yucca Flat and Frenchman Flat, were filled with alluvial debris eroded from the adjacent highlands during basin development. The thickness of alluvial deposits in these basins exceeds 1,067 m (3,500 ft) (Drellack and Thompson, 1990; NNSA/NSO, 2005b).

Geologic structures (faults and folds) are also an important factor in the distribution of HSUs in the NTS region. Structures define the geometric configuration of the area, including the distribution, thickness, and orientation of units. Synvolcanic structures, including caldera faults and some normal faults, had a strong influence on depositional patterns of many of the units, which display abrupt and dramatic lithologic and thickness changes across caldera margins (Byers et al., 1976; Ferguson et al., 1994).

A generalized geologic map of the NTS area is given in Figure 1-3. Figure 1-4 is a more detailed geologic map that illustrates the geologic complexity of the NTS area. A comprehensive list of the stratigraphic units in the NTS area is provided in Plate 1. 


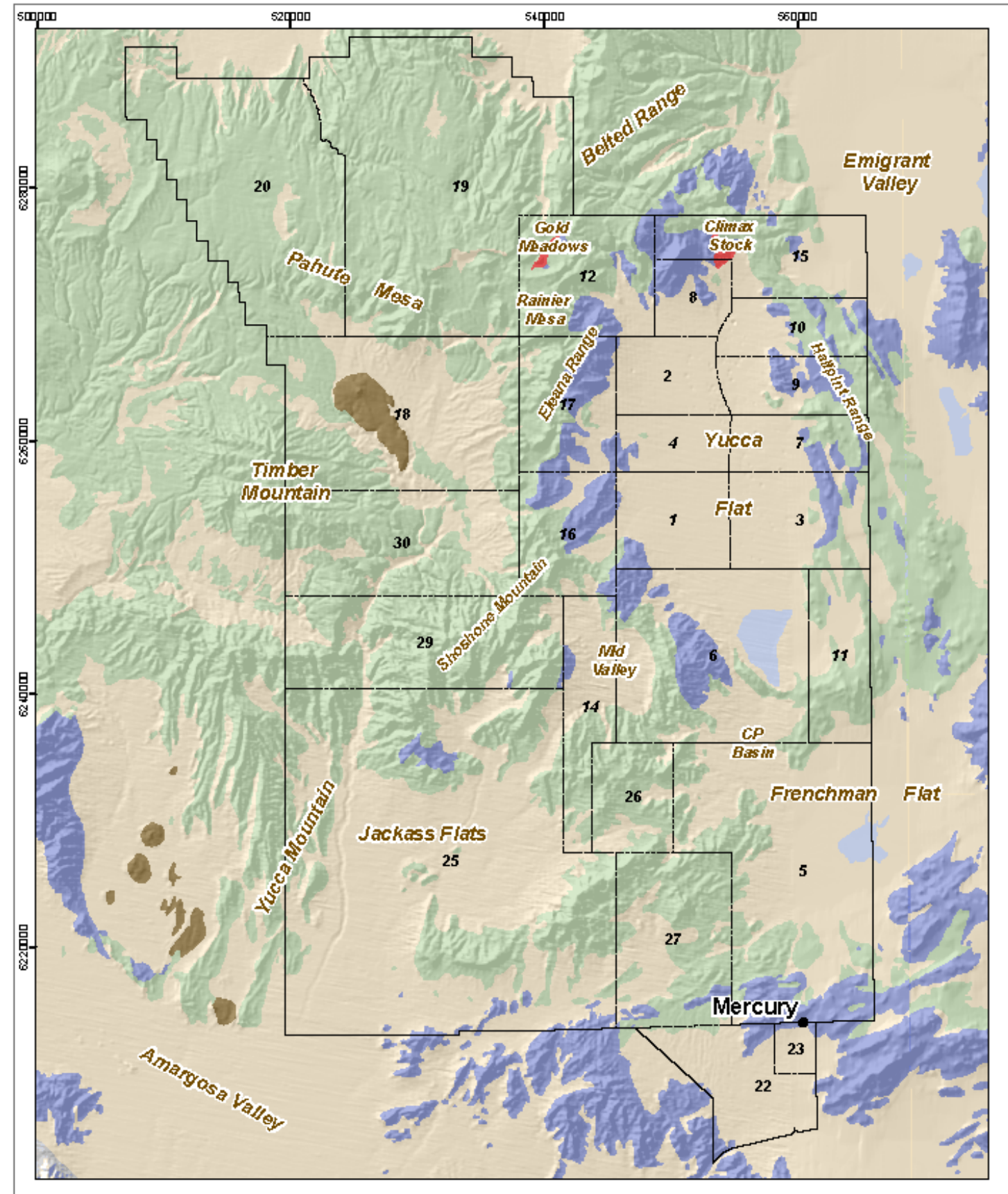

Quaternary playa deposits Quaternary/Tertiary

NTS boundary
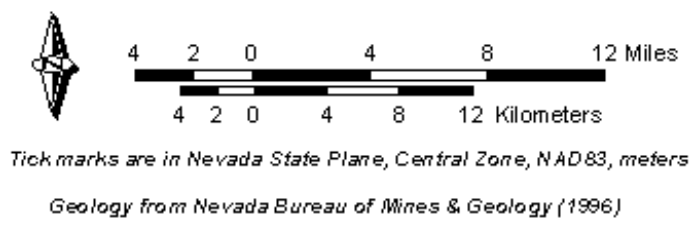

Pliocene basaltic rocks

Tertiary volcanic rodks

Mesozoic granitic rooks

P aleozoic \& Precambrian

sedimentary rocks

Figure 1-3

Generalized Geologic Map of the Nevada Test Site Area 


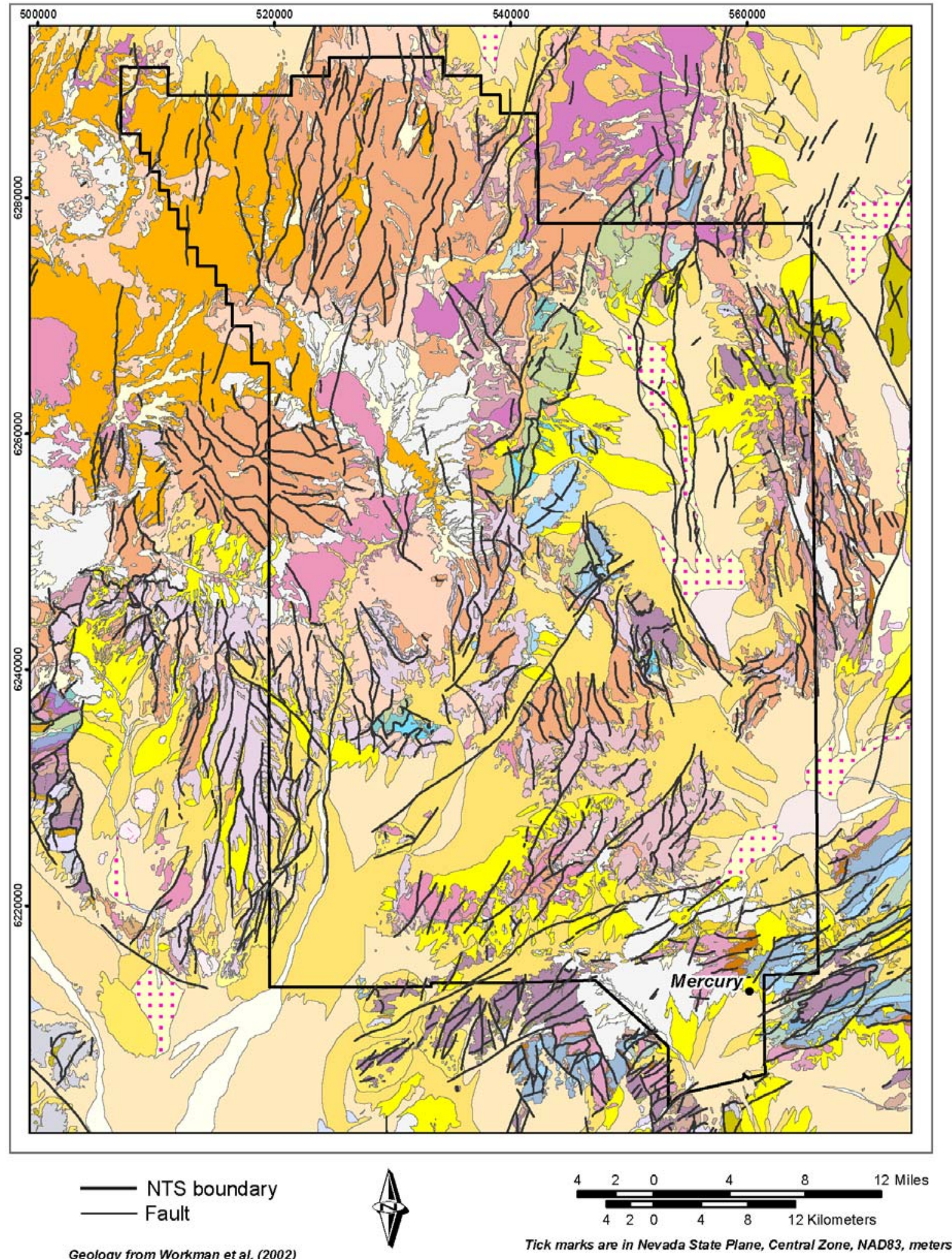

Figure 1-4

Detailed Geologic Compilation Map of the Nevada Test Site Area 


\subsection{Hydrologic Setting}

The hydrologic character of the NTS and vicinity reflects the region's arid climatic conditions and complex geology (D’Agnese et al., 1997). The hydrology of the NTS has been extensively studied for over 50 years (U.S. Department of Energy, Nevada Operations Office [DOE/NV], 1996) and numerous scientific reports and large databases are available to project scientists.

The NTS is located within the southern portion of the Great Basin (Figure 1-2), a hydrographic province characterized by internal drainage of surface water within numerous hydrologically closed topographic basins that are generally related to the basin-and-range style topography of the region (Laczniak et al., 1996). Examples of hydrologically closed basins at the NTS are Yucca Flat and Frenchman Flat. Streams in the region are ephemeral, flowing as runoff in response to precipitation events or snowmelt.

The NTS also lies within the Death Valley regional groundwater flow system, one of the major hydrologic subdivisions of the southern Great Basin (Waddell et al., 1984; Laczniak et al., 1996). The Death Valley regional groundwater flow system is subdivided into groundwater subbasins, three of which occur within the boundaries of the NTS (Figure 1-5). Recharge areas for the Death Valley groundwater system are the higher mountain ranges of central and southern Nevada, where there can be significant precipitation and snow-melt. Groundwater flow is generally from these upland areas to natural discharge areas in the south and southwest.

Groundwater at the NTS is also derived from underflow from basins up-gradient of the area (Harrill et al., 1988). The direction of groundwater flow is influenced locally by structure, rock type, or other geologic conditions. Existing water-level data (Reiner et al., 1995; IT Corporation [IT], 1996b) and results of modeling groundwater flow (IT, 1996a; D’Agnese et al., 1997) indicate that the general groundwater flow direction within major water-bearing units beneath the NTS is to the south and southwest (Figure 1-5).

The groundwater-bearing rocks at the NTS have been classified into several aquifers and confining units, of which the most important is the lower carbonate aquifer (LCA), a thick sequence of Paleozoic carbonate rock. This unit is present throughout the subsurface of central and southeastern Nevada, and is considered to be a regional aquifer (Winograd and Thordarson, 1975; Laczniak et al., 1996; IT, 1996a).

Groundwater discharge at the NTS is minor, consisting of small springs that drain perched water lenses, and artificial discharge at a limited number of water supply wells. Springs that emanate from local perched groundwater systems are the only natural sources of perennial surface water 


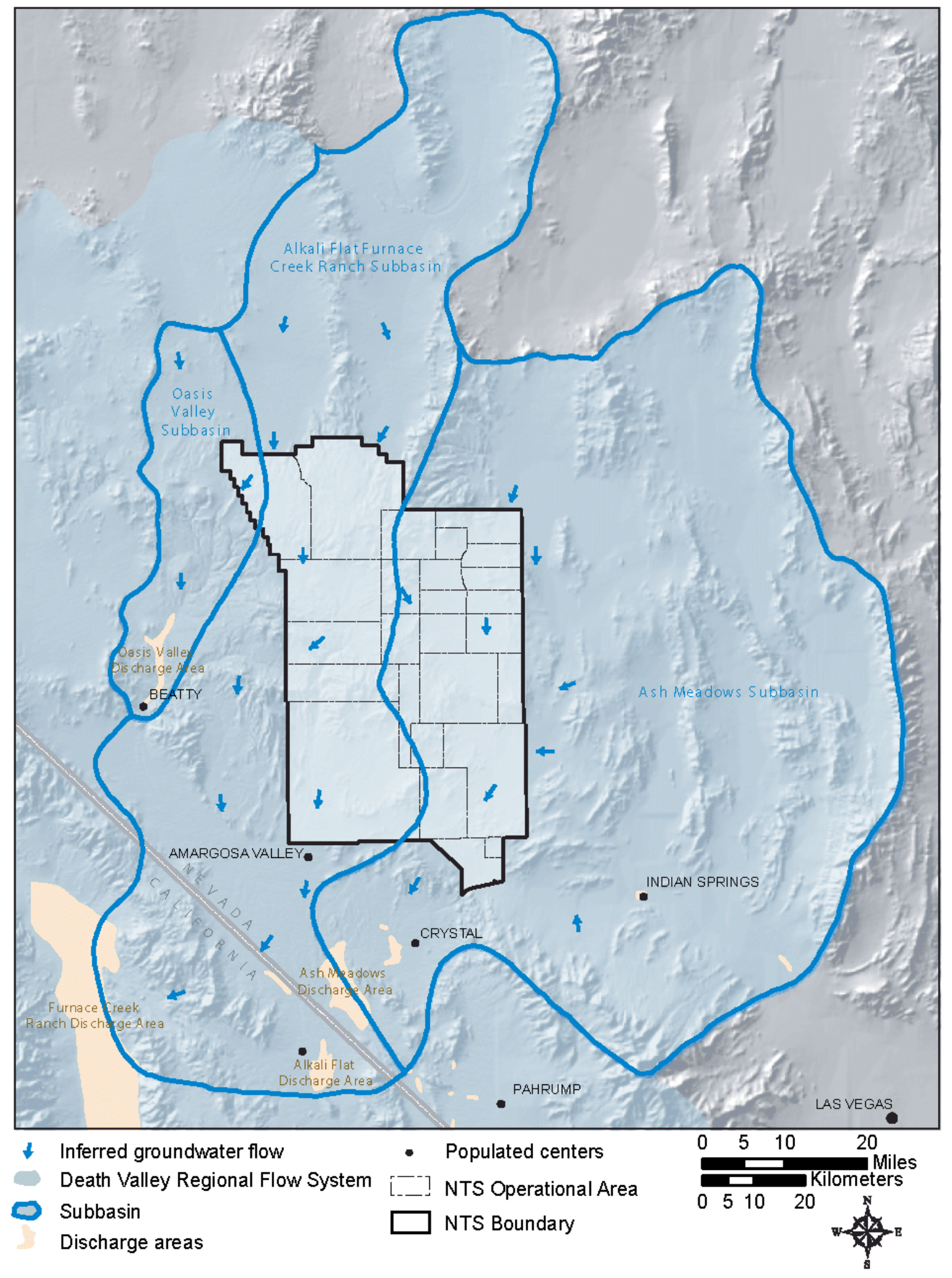

Figure 1-5

Groundwater Sub-Basins of the Nevada Test Site and Vicinity

(Modified from Waddell et al. [1984] and Laczniak et al. [1996]) 
in the region. Spring discharge rates are low, ranging from 0.014 to 2.2 liters/second ( 0.22 to 35 gallons/minute) (Hansen et al., 1997). Most water discharged from springs travels only a short distance from the source before evaporating or infiltrating into the ground.

In general, the static water level across the NTS is deep, but measured depths vary depending on the land elevation from which each well was drilled. The depth to groundwater in wells at the NTS varies from about $210 \mathrm{~m}$ ( $690 \mathrm{ft}$ ) below the land surface under the Frenchman Flat playa in

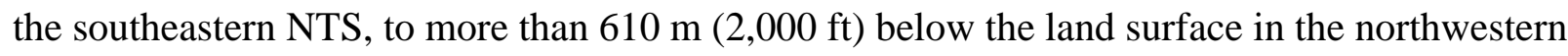
NTS, beneath Pahute Mesa (IT, 1996b; Reiner et al., 1995). Water-level elevations range from $730 \mathrm{~m}$ (2,400 ft) at Frenchman Flat to 1,450 m (4,760 ft) on Pahute Mesa. Perched groundwater (isolated lenses of water lying above the regional groundwater level) occurs locally throughout the NTS, mainly within volcanic rocks.

\subsection{UGTA Hydrostratigraphic Framework Models}

The hydrostratigraphic system forms the foundation of all UGTA CAU-scale HFMs on which flow and transport models are developed. HFMs are computer models that establish and depict the three-dimensional relationships of HSUs and structural features within a CAU model area. The HFMs are constructed using EarthVision ${ }^{\circledR}$ software. Model input data include a digital elevation model of the land surface, elevations of the tops of HSUs based on drill hole intercepts and surface exposures, HSU isopach (i.e., thickness) and unit extent maps, and locations and orientations of faults (BN, 2002; 2005; 2006; NSTec, 2007). Fault data are used to construct a fault-tree model, which effectively subdivides the model area into numerous fault blocks. HSUs are assigned a stratigraphic order, and EarthVision ${ }^{\circledR}$ then "stacks" the HSUs from lowest to highest, according to their ordering within each fault block, using geology-based geometric "rules" that honor the input data within each block, but also consider data from adjacent fault blocks. The resulting 3-D computer model can be rotated in any direction, sliced vertically and horizontally, and individual layers (i.e., HSUs) can be added or removed. This allows for a thorough review and evaluation of the model.

The base HFM is the HFM for a particular CAU that is thought to best represent the subsurface geology. There is one base model per CAU. However, because of the complexity of the geology at the NTS, more than one interpretation of the subsurface geology is possible in some areas. To address non-unique aspects of hydrologically significant interpretations within the base HFMs, alternative HFMs were developed that incorporated different interpretations than those in the base HFMs. This allows for the exploration of how groundwater flow might differ if the alternative HFM is closer to the true configuration of the subsurface geology than the base 
model. Only those portions of the base model affected by the alternative interpretations were modified to produce an alternative HFM.

The boundaries of all the UGTA CAU-scale model areas, which correspond to the boundaries of the HFMs, are shown in Figure 1-1. Examples of UGTA CAU-scale HFMs are provided in Figures 1-6 and 1-7. Figure 1-6 is a 3-D cut-away view of the Yucca Flat-Climax Mine (YF-CM) HFM (BN, 2006). Figure 1-7 shows a two-dimensional profile through the Pahute Mesa-Oasis Valley (PM-OV) HFM (BN, 2002). 


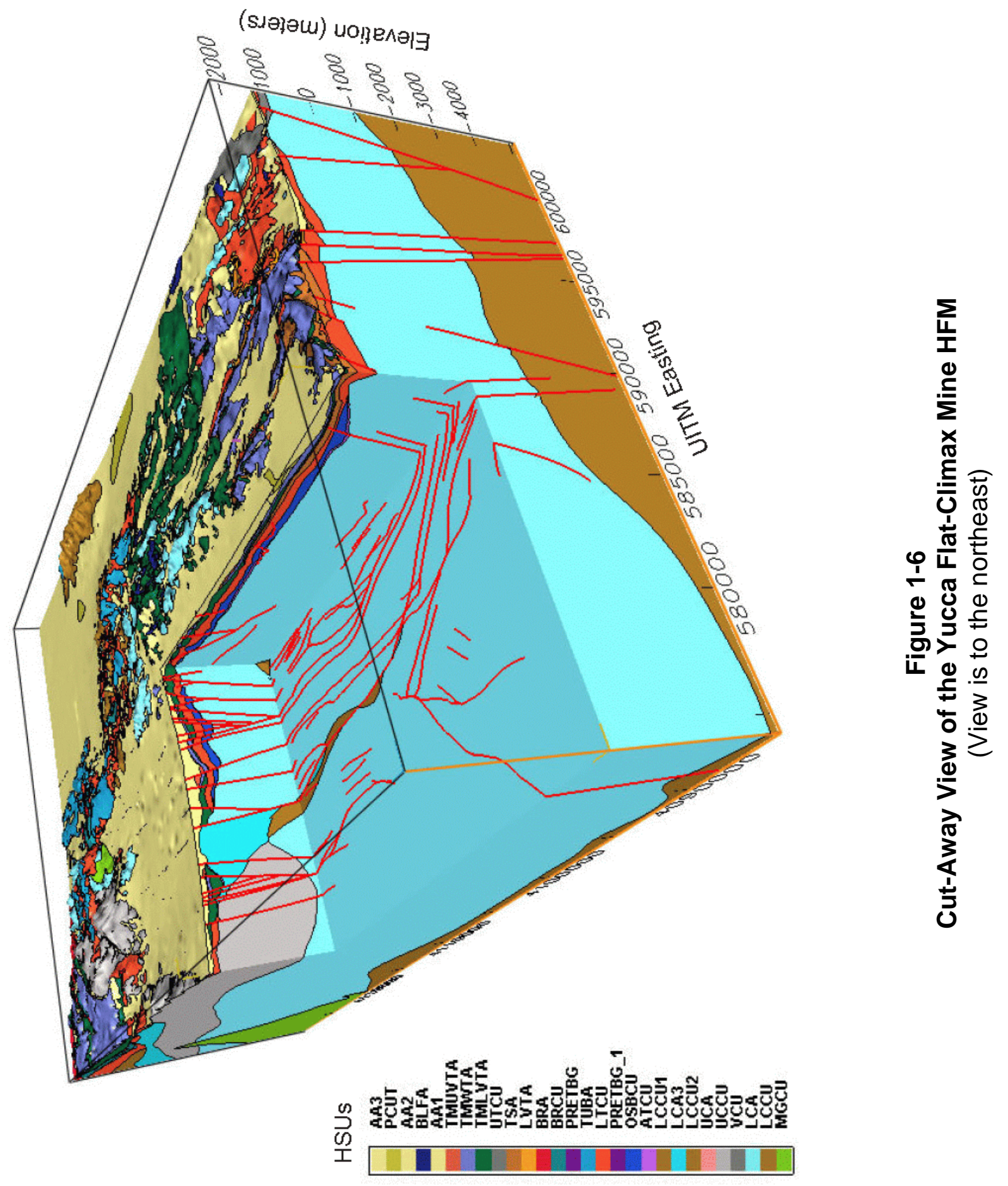




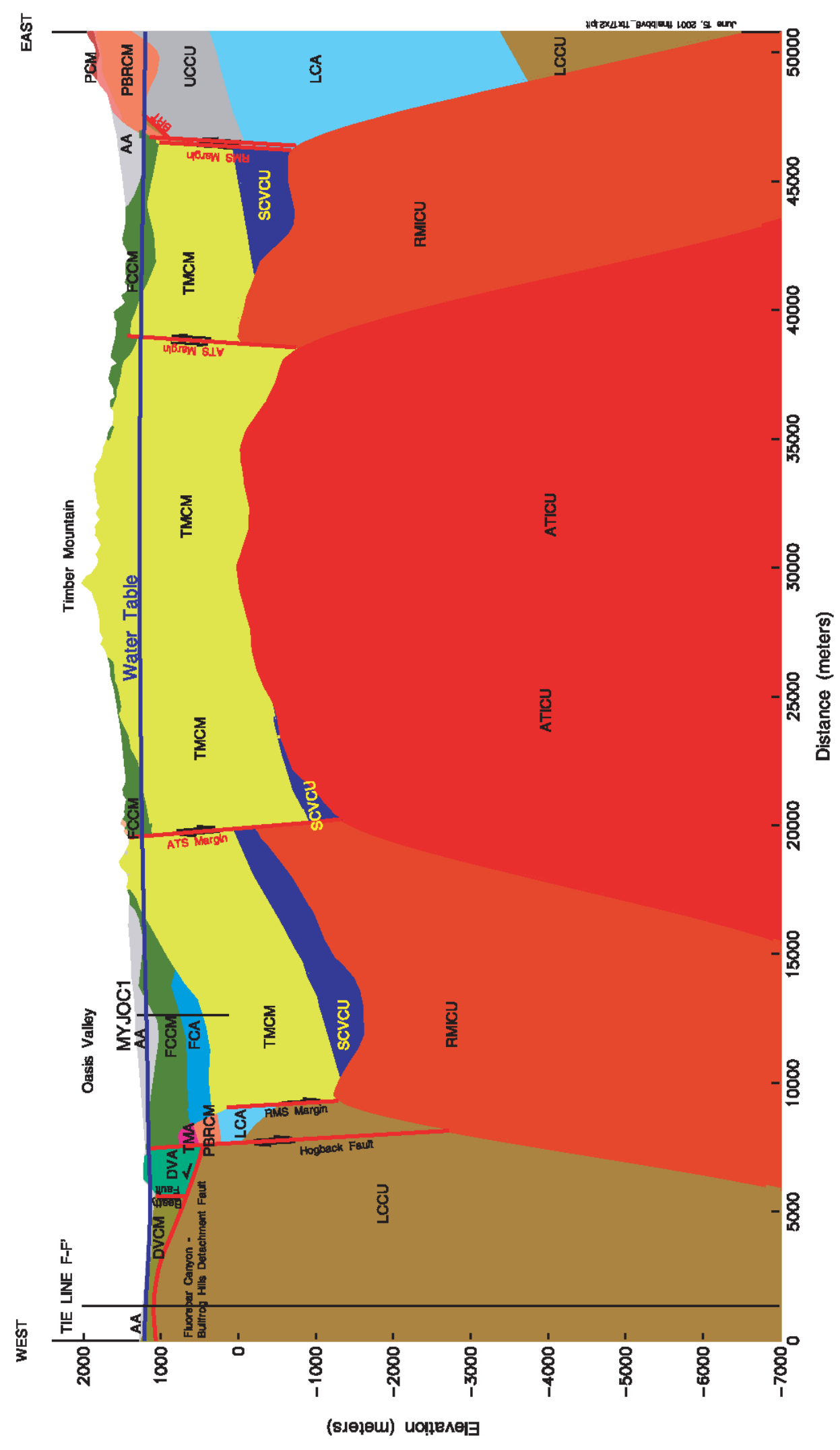

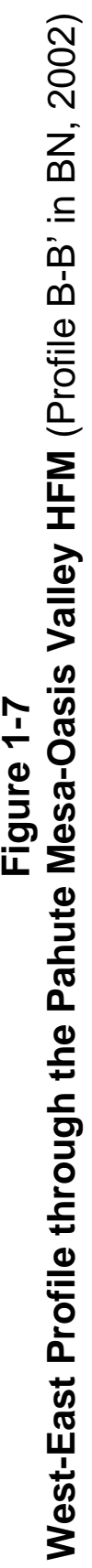


This page intentionally left blank. 


\subsection{Data Sources}

Geoscientists have been working in the NTS area for more than 50 years, and many sources of geologic and hydrologic information and data are available. Specific data sources for the Frenchman Flat area are discussed in BN (2005), for the PM-OV area in BN (2002), for the YF-CM area in BN (2006), and for the Rainier Mesa-Shoshone Mountain (RM-SM) area in NSTec (2007). Typical data sources available for characterization work at the NTS are described in the following subsections. The development of a CAU-scale hydrostratigraphic system in such a complex geologic setting as the NTS region would be impossible without the large body of geologic, geophysical, and hydrologic data now available from both Weapons Testing Program (WTP) and UGTA Sub-Project investigations.

\subsection{Geologic Mapping}

Geologists working for the U.S. Geological Survey (USGS) have been mapping in the NTS area since the 1950s, and have produced numerous high quality geologic quadrangle maps at a scale of 1:24,000 (Figure 2-1). This early detailed geologic mapping established the basic stratigraphic and structural frameworks that have survived decades of scientific evaluation and are still used today. The geologic quadrangle maps are an extremely valuable resource, and the UGTA Sub-Project is fortunate to have access to such basic, high quality geologic data. Larger scale geologic compilation maps include Frizzell and Shulters (1990), Slate et al. (1999), and Workman et al. (2002).

\subsection{Drill Hole Data}

More than 4,000 boreholes have been drilled on and around the NTS for various purposes

(Figure 2-2), including water production and monitoring wells, emplacement holes and post-shot holes for underground nuclear tests, exploratory holes, and holes for underground instrumentation (Raytheon Services Nevada, 1990). In addition to typical stratigraphic and lithologic information, data from geophysical logs, geologic samples, and hydrologic testing in the boreholes have added information about the character of the geologic units penetrated. Most of these data have been compiled, analyzed, and organized into databases (Warren et al., 2003; BN, 2002; Drellack and Thompson, 1990; Wagoner and Richardson, 1986; and various unpublished BN, Lawrence Livermore National Laboratory, and Los Alamos National Laboratory databases; see references in Section 5.0). During development of the UGTA Phase I regional model, some of these data were compiled, analyzed, and organized into databases for import into modeling software applications (circa 1996). For the CAU-scale modeling 

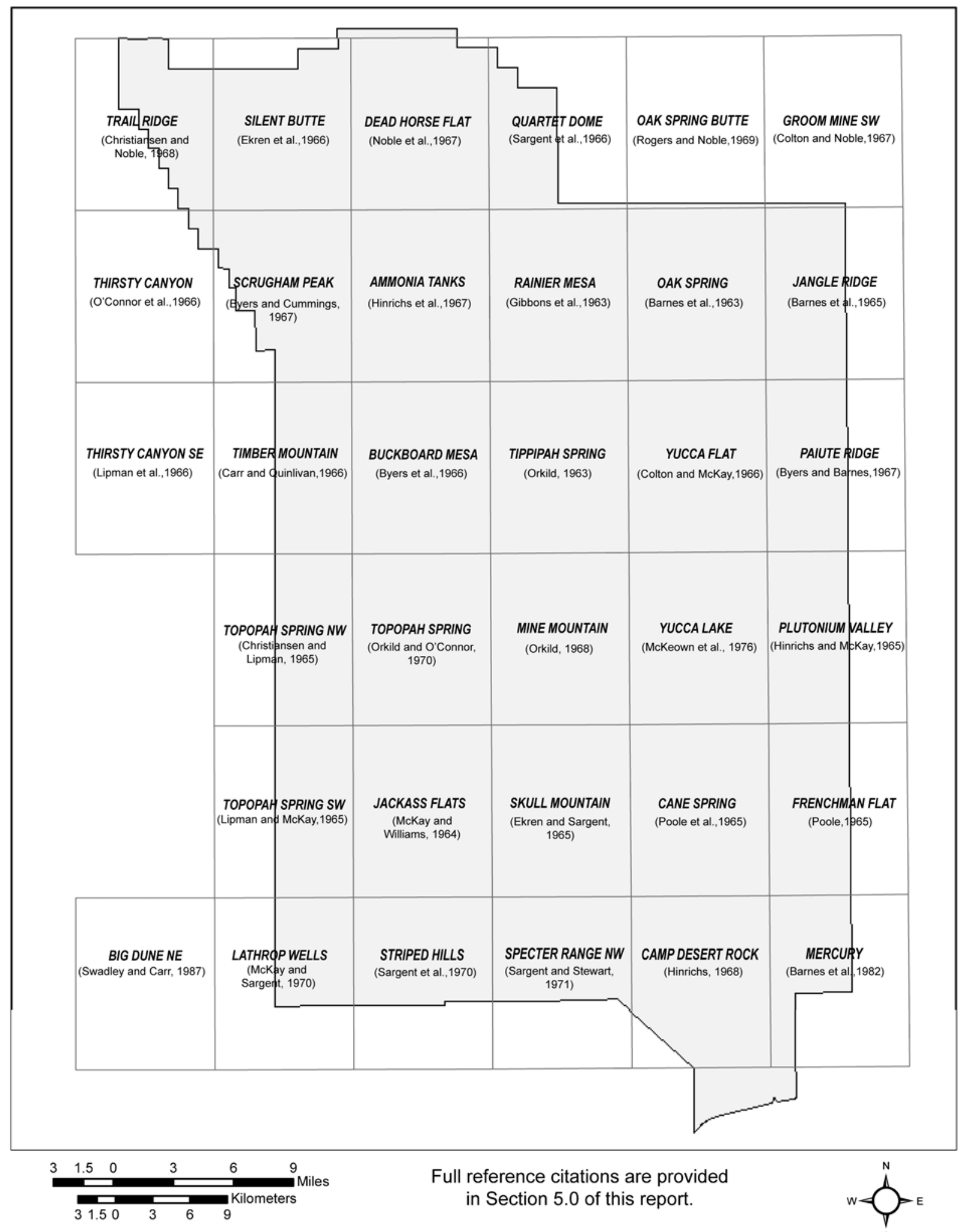

Full reference citations are provided in Section 5.0 of this report.

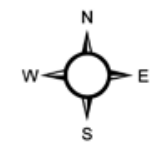

Figure 2-1

Locations of Geologic Quadrangle Maps Covering the Nevada Test Site Area 


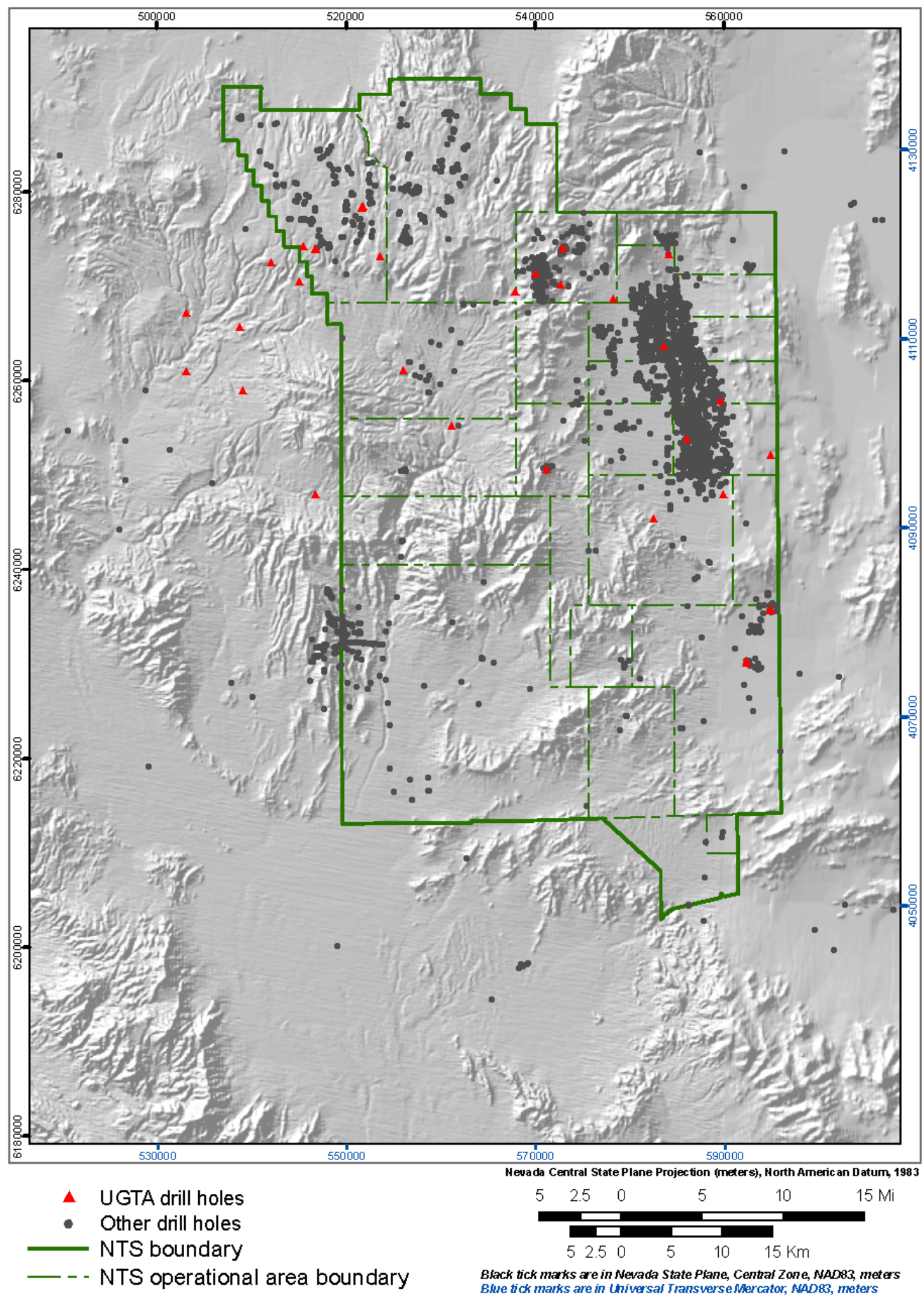

Figure 2-2

Distribution of Boreholes on the Nevada Test Site and Surrounding Areas That Have Been Drilled or Utilized by DOE Activities 
initiatives, a much more intensive data compilation and evaluation effort was implemented (BN, 2002; 2005; 2006; NSTec, 2007). Boreholes providing input for the CAU-scale models are listed in Appendix A of the respective HFM documentation reports. The boreholes provide information on the geologic and hydrologic character and distribution of subsurface units.

Although much of the drill-hole information is typically referred to as data, it should be noted that such information, particularly stratigraphic and lithologic information, is produced through a rigorous interpretive process based on an integrated analysis of drill cuttings, rock core, geophysical logs, and nearby surface exposures. Results from laboratory analyses such as petrography, x-ray diffraction, and x-ray fluorescence are also commonly integrated into the stratigraphic interpretation.

\subsection{Tunnel Data}

Six large and several smaller tunnel complexes were constructed at Rainier Mesa for underground nuclear testing, starting in the 1950s and continuing through the early 1990s, when the current nuclear testing moratorium began (Figure 2-3). In addition, the U16a Tunnel complex at Tippipah Point in NTS Area 16 was also used to conduct similar tests in the 1960s and early 1970s (Figure 2-4). Tunnel complexes were also constructed for nuclear tests in granite in Area 15.

Most of these tunnel complexes have in common a history of intense geologic study. For most tunnel tests, extensive geologic, geomechanical, and geophysical studies were made of the test bed to support engineering design, containment design, and containment evaluation. Expanded summaries for each of the main tunnel complexes in Areas 12 and 16 are provided in NSTec (2007).

\subsection{Geophysical Investigations}

Numerous geophysical investigations have been conducted at the NTS since the 1950s and include gravity, magnetic, resistivity, and seismic. Most of the geophysical surveys were conducted in active testing areas such as Yucca Flat and Rainier Mesa in support of the WTP. Many of the geophysical surveys were designed to address very specific and local geological issues related to a specific underground test and thus are of limited use in constructing CAUscale HFMs. These data include mainly tunnel and borehole velocity, gravity, and resistivity measurements (Carroll, 1986; 1990; 1994; Carroll and Kibler, 1983; Kososki et al., 1978; Hearst and Burkhard, 1989). More recent geophysical data were collected specifically for the UGTA 


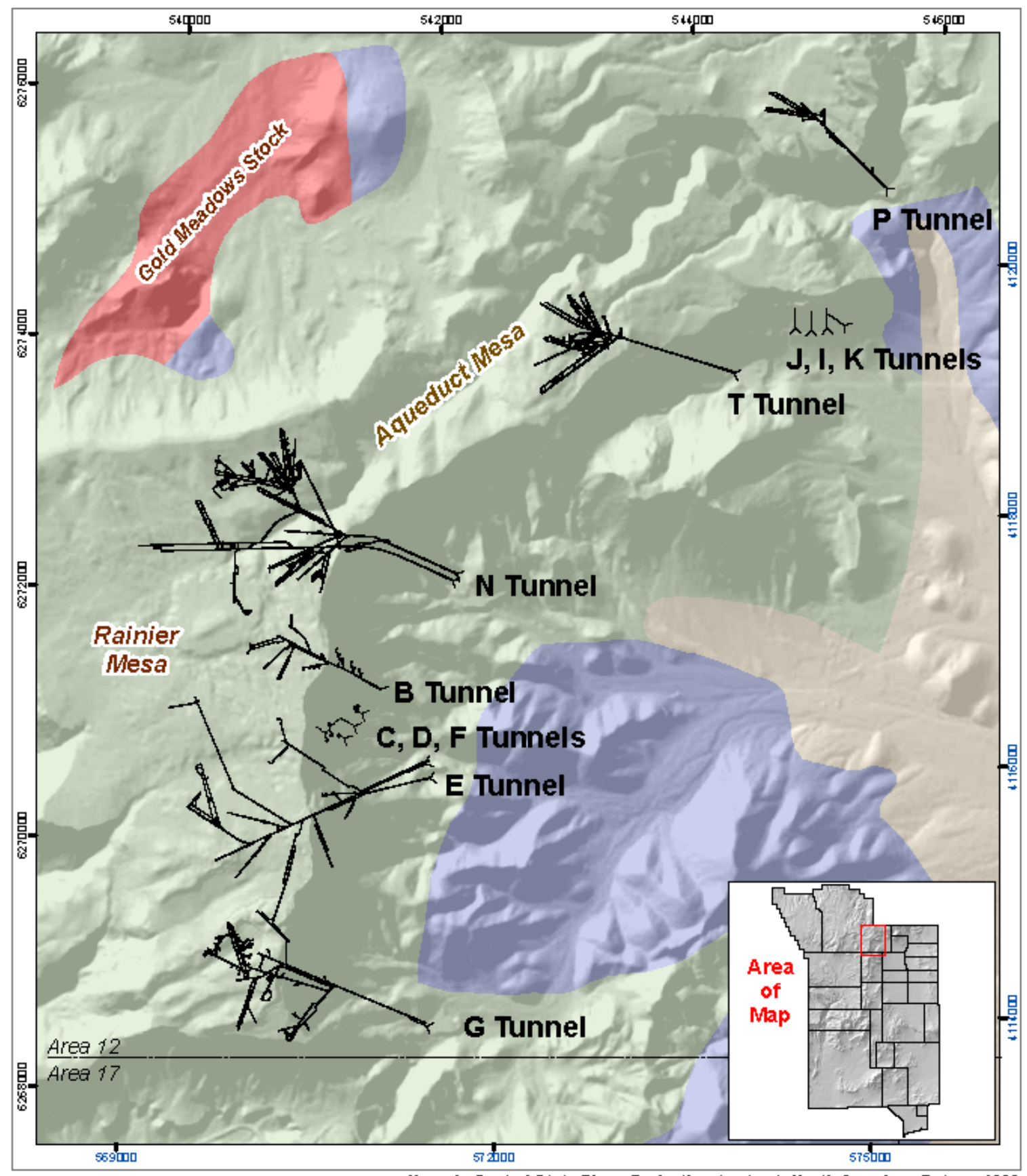

\section{Quaternary/Tertiary
alluvial sediments}

Tertiary volcanic rocks

Mesozoic granitic rocks

Paleozoic \& Precambrian sedimentary rocks

Hevada Central State Plane Projection (meters), Horth American Datum, 1983

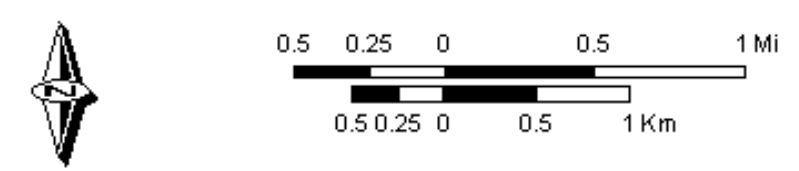

Bhck tick marks are in Nevada State Pkme, Central Zone, NAD83, meters bive tick marks are in Universal Transverse Mrcator, NAD83, meters

Geokgy from Mevada Bureau of Mmes \& Geokgy (1996)

Figure 2-3

Generalized Geologic Map of the Rainier Mesa Area Showing Locations of Area 12 Tunnel Complexes in which Nuclear Tests were Conducted 


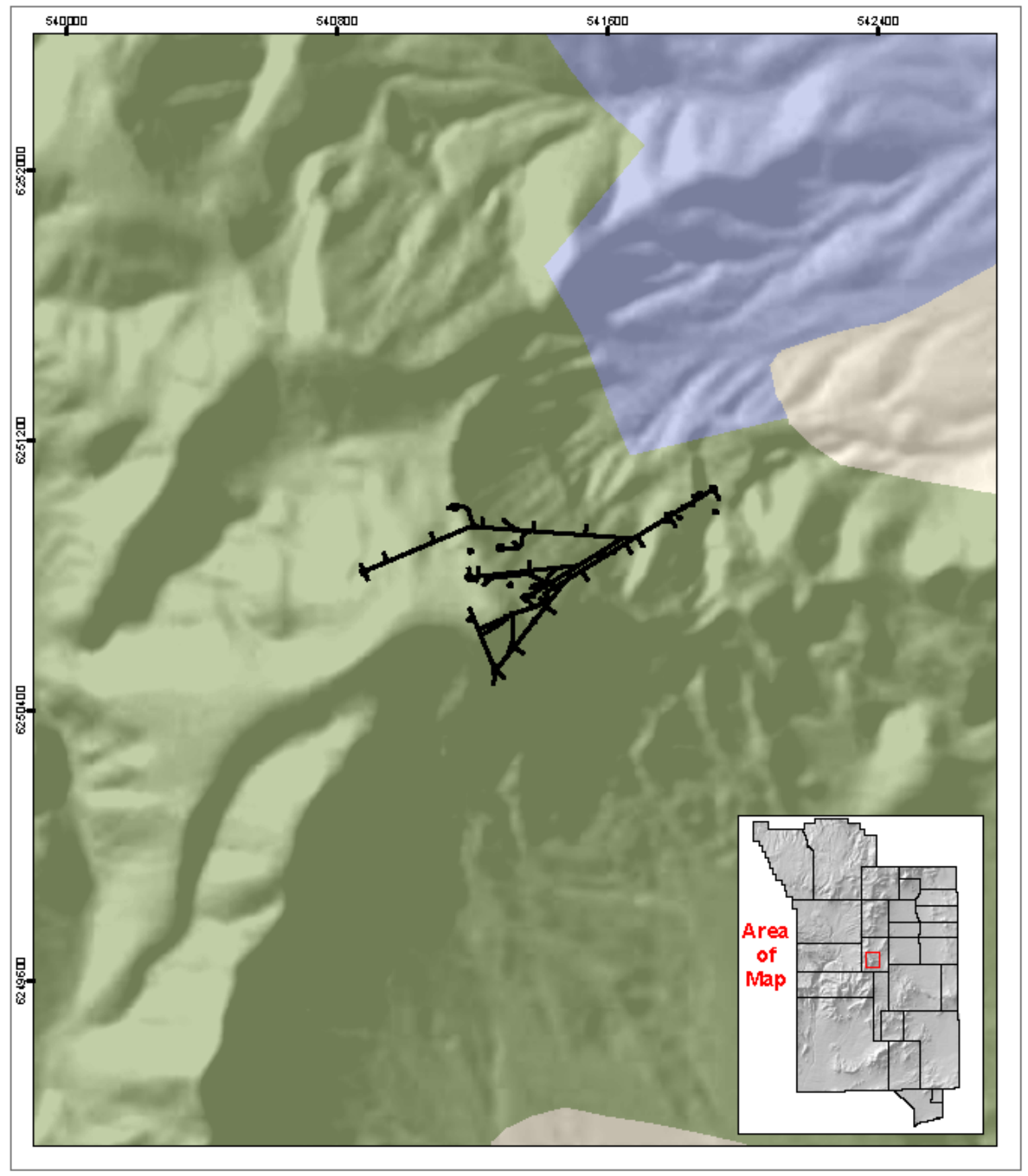

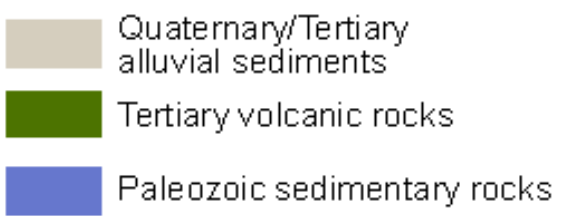

Geology from Mevada Burean of Mhes \& Geology (1996)

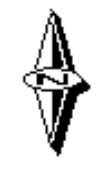

Tick marks are in Mevada State Plame, Central Zone, NAD83, mete is

Figure 2-4

Generalized Geologic Map of the Shoshone Mountain Area Showing Location of the U16a Tunnel Complex 
modeling efforts. Information from geophysical investigations was integrated with surface geology and drill hole data to help in the interpretation of the distribution of HSUs and develop structural models. Some of the geophysical methods and studies considered during the construction of UGTA HFMs are itemized below.

A. The collection and analysis of gravity data have been an integral part of geologic investigations at the NTS since the early 1960s (McCafferty and Grauch, 1997; Grauch et al., 1997; Healey et al., 1987; Jachens and Moring, 1990; Ponce et al., 1988; Ponce et al., 1999). Gravity data have been used to help define basin architecture, locate buried faults, and estimate depth to pre-Tertiary rocks buried by volcanic rocks and alluvium. Gravity data played a critical role in the recognition and characterization of buried calderas such as the Silent Canyon caldera complex (Healey, 1968) and, more recently, the Redrock Valley caldera (NSTec, 2007).

B. Ground magnetic surveys were conducted during special geologic and geophysical studies within the former testing areas of Yucca Flat, Pahute Mesa, and Rainier Mesa, mainly in support of the WTP (Bath et al., 1983; Orkild et al., 1983). The surveys were typically used to identify buried faults by determining the configuration of the nearsurface volcanic rocks. Other ground magnetic surveys were conducted in support of individual underground tests, for example, to help locate faults in areas with thin alluvial cover.

C. Numerous aeromagnetic surveys and related investigations have been conducted at the NTS in the past several decades mainly in support of the WTP (Kirchoff-Stein et al., 1989; McCafferty and Grauch, 1997; Ponce, 1999). Aeromagnetic data were used to help define the subsurface shape of the Climax and Gold Meadows granitic stocks (Bath et al., 1983; Phelps et al., 2004). Aeromagnetic data have also been used at the NTS to delineate buried structures by identifying linear magnetic anomalies within buried volcanic rocks. However, subsurface structural interpretations of aeromagnetic data at the NTS are generally poorly constrained due mostly to the great thickness of alluvium within the basins, and the presence of both normally and reversely magnetized volcanic units (e.g., the Ammonia Tanks and Rainier Mesa tuffs).

D. Since 2003, the USGS has been conducting natural-source magnetotelluric (MT) surveys for the UGTA Sub-Project to better constrain pre-Tertiary stratigraphy and structures buried beneath thick sequences of alluvium and volcanic rocks. MT data from Yucca Flat proved particularly useful in constraining the extent and thickness of the upper clastic confining unit (UCCU) HSU beneath the basin (BN, 2006; Asch et al., 2006). This improved stratigraphic understanding led to a revised and better constrained structural model of the pre-Tertiary rocks beneath Yucca Flat. 
E. Half-refraction surveys were conducted in Yucca Flat for the WTP in an attempt to map the pre-Tertiary surface near selected test locations (App, 1983). Seismic refraction surveys were conducted in many drifts and boreholes in the Rainier Mesa and Shoshone Mountain tunnel complexes, primarily for determination of the velocity of the medium as input to ground shock calculations for underground explosions (Carroll, 1986; 1994; Carroll and Kibler, 1983). Data from some of these surveys were also used to characterize regions of damage following underground tests (Carroll, 1983).

F. Two-dimensional seismic reflection surveys have been conducted in two portions of the RM-SM model area. In Yucca Flat, approximately 225 kilometers (140 miles) of two-dimensional seismic surveys have been conducted. Most of these data were acquired between 1970 and 1985 in support of the WTP at the NTS (App, 1983; Burkhard, 1983). A seismic survey consisting of three lines was conducted in Mid Valley (McArthur and Burkhard, 1986) to evaluate the area for underground nuclear testing. Seismic reflection surveys in Yucca Flat and Mid Valley were successful in imaging the general geology above the pre-Tertiary surface, including the contact between the alluvium and underlying volcanic rocks, the distribution of welded volcanic rocks, and the major faults that offset these units. Due to a variety of geologic and geophysical factors, the seismic reflection method has been mostly unsuccessful in imaging pre-Tertiary stratigraphy and structure beneath basins at the NTS (Burkhard, 1983).

G. A high resolution 3-D seismic reflection survey was conducted in Frenchman Flat in 2001. The purpose of the survey was to better constrain structural interpretations and distributions of HSUs beneath the underground nuclear testing areas in Frenchman Flat. This endeavor was quite successful and contributed substantially to the constructions of the Phase II Frenchman Flat HFM (BN, 2005). 


\subsection{The UGTA CAU-Scale Hydrostratigraphic System}

Maxey (1964) was the first to propose that a category of HSUs be formally recognized so that "geohydrologic" units, such as aquifers and confining units, could be clearly set apart from other rock groupings such as lithologic and rock-stratigraphic units, as well as to clarify usage in hydrogeologic applications. Maxey (1964) proposed that HSUs be defined as "bodies of rock with considerable lateral extent that compose a geologic framework for a reasonably distinct hydrologic system.” Although recognizing that some of the same criteria (e.g., lithology) used to define rock-stratigraphic units are still "basic factors" in defining HSUs, a set of different parameters was necessary for HSU designation. These included geology-related parameters such as the distribution and characteristics of primary and secondary porosity and permeability, as well as parameters related to the dynamics of the hydrological regime such as movement, storage, and release of water, and water-well construction methods and locations.

Seaber (1988) argued that parameters related to the dynamics of the hydrologic regime are not material properties, and that inclusion of such parameters in the definition of HSUs severely reduces the regional applicability of such a categorical system. Consequently, Seaber (1988) proposed a redefinition of an HSU based on the characteristics of a rock's interstices, and defined an HSU as "a body of rock distinguished and characterized by its porosity and permeability.” The stated purpose of Seaber (1988) was to "promote uniform and unambiguous methods to be used in partitioning any type of body of rock into hydrostratigraphic units, based on their inherent, mappable porosity and permeability.” Like rock-stratigraphic units, HSUs should be recognizable, mappable, traceable, and reproducible.

The UGTA CAU-scale hydrostratigraphic classification system includes hydrostratigraphic concepts consistent with portions of both Maxey (1964) and Seaber (1988), and is built using the abundant geologic and hydrologic data available for the NTS region. Consistent with the proposal of Seaber (1988), the UGTA CAU-scale hydrostratigraphic system organizes volumes of rock into HSUs based mainly on the nature of their porosity and permeability. However, 3-D model development requires that rock- and time-stratigraphic information and concepts be carefully integrated into the system, as recognized by Maxey (1964), to assure that HSUs correctly correlate throughout the various HFMs.

As mentioned previously, the construction of UGTA CAU-scale HFMs required a hydrostratigraphic classification system that consistently defines the lateral and vertical distributions of HSUs within a very complex geologic setting. To achieve this requirement, the 
UGTA CAU-scale hydrostratigraphic system uses a two-level classification scheme, in which hydrogeologic units (HGUs) are organized into HSUs that form the unit volumes, or layers, within the HFMs.

\subsection{Hydrogeologic Units}

The hydrogeologic framework established by Winograd and Thordarson (1975) delineated the various aquifers and aquitards within the NTS region. Like most post-1975 hydrologic studies in the NTS vicinity (e.g., Laczniak et al., 1996), the UGTA CAU-scale hydrostratigraphic system uses most of the aquifer and aquitard designations of Winograd and Thordarson (1975). The UGTA CAU hydrostratigraphic system, however, follows Maxey (1964), USGS (1991), and, Laczniak et al. (1996), and uses the term “confining unit” for all non-aquifer rocks, including aquitards.

Within the UGTA CAU-scale hydrostratigraphic system, HGUs categorize aquifers and confining units according to the nature of their porosity and permeability; thus, the UGTA HFMs follow Seaber's (1988) proposed definition of an HSU. Rocks in the model area are classified as one of ten HGUs based on the rock's ability to transmit groundwater (Table 3-1), which is mainly a function of the rock's primary lithology, type and degree of post-depositional alteration, and propensity to fracture (Winograd and Thordarson, 1975; BN, 2002; 2005; 2006; NSTec, 2007).

The most important factor affecting how groundwater flows through a body of rock is the rock's original primary lithology, which exerts a strong influence on the other two important processes, post-depositional alteration and fracturing. Hard, dense, rigid rocks such as welded ash-flow tuff, the interior portion of lava, and carbonate generally have low matrix porosity and permeability, but tend to fracture readily in response to tectonic forces and, as in the case of welded tuffs and lavas, also as a result of contraction during cooling. In addition, the low primary porosity and matrix permeability of these rocks tend to inhibit significant secondary alteration, such as zeolitization and argillization, which typically changes the hydrologic character of the rocks. These rocks are considered aquifers and have been shown to be prolific water producers at the NTS.

Less dense rocks, such as alluvium and bedded and nonwelded tuff, typically do not support extensive fracture systems and thus usually have low fracture-related permeability. However, some low density rocks, such as nonwelded tuff and alluvium, can have relatively high matrix 
Table 3-1

Hydrogeologic Units of the Nevada Test Site

(Adapted from Winograd and Thordarson [1975]; IT [1996a]; and Laczniak et al. [1996])

\begin{tabular}{|c|c|c|}
\hline $\begin{array}{c}\text { Hydrogeologic } \\
\text { Unit }\end{array}$ & Typical Lithologies & Hydrologic Significance \\
\hline $\begin{array}{l}\text { Alluvial aquifer } \\
\quad(A A) \\
\text { (AA is also an HSU) }\end{array}$ & $\begin{array}{l}\text { Unconsolidated to partially } \\
\text { consolidated gravelly sand, } \\
\text { eolian sand, and colluvium }\end{array}$ & $\begin{array}{l}\text { Has characteristics of a highly conductive } \\
\text { aquifer, but less so where lenses of clay-rich } \\
\text { paleocolluvium or zeolitic alteration are present. }\end{array}$ \\
\hline $\begin{array}{l}\text { Welded-tuff aquifer } \\
\text { (WTA) }\end{array}$ & $\begin{array}{l}\text { Welded ash-flow tuff; vitric to } \\
\text { devitrified }\end{array}$ & $\begin{array}{l}\text { Degree of welding greatly affects interstitial } \\
\text { porosity (i.e., less porosity as degree of welding } \\
\text { increases) and permeability (i.e., greater fracture } \\
\text { permeability as degree of welding increases). }\end{array}$ \\
\hline $\begin{array}{l}\text { Vitric-tuff aquifer } \\
\quad \text { (VTA) }\end{array}$ & $\begin{array}{l}\text { Bedded tuff; ash-fall and } \\
\text { reworked tuff; vitric }\end{array}$ & $\begin{array}{l}\text { Constitutes a volumetrically minor HGU. } \\
\text { Generally does not extend far below the static } \\
\text { water level due to tendency of tuff to become } \\
\text { zeolitic under saturated conditions, which } \\
\text { drastically reduces permeability. Significant } \\
\text { interstitial porosity (i.e., } 20 \text { to } 40 \text { percent). } \\
\text { Generally insignificant fracture permeability. }\end{array}$ \\
\hline $\begin{array}{l}\text { Lava-flow aquifer } \\
\text { (LFA) }\end{array}$ & $\begin{array}{l}\text { Rhyolite, basalt and dacite } \\
\text { lava flows; includes flow } \\
\text { breccia (commonly at base) }\end{array}$ & $\begin{array}{l}\text { Generally occurs as small, moderately thick } \\
\text { (rhyolite) to thin (basalt) local flows. } \\
\text { Hydrologically complex, showing a wide range of } \\
\text { transmissivity values. Fracture density and } \\
\text { interstitial porosity differ with lithologic variations. }\end{array}$ \\
\hline $\begin{array}{l}\text { Playa confining unit } \\
\text { (PCU) }\end{array}$ & Silt and clay & $\begin{array}{l}\text { Near-surface confining unit at Yucca and } \\
\text { Frenchman Lakes and within lower portion of } \\
\text { alluvial section in the deepest portions of } \\
\text { Frenchman Flat. }\end{array}$ \\
\hline $\begin{array}{l}\text { Tuff confining unit } \\
\text { (TCU) }\end{array}$ & \begin{tabular}{|l|} 
Zeolitic bedded tuff with \\
interbedded, but less \\
significant, zeolitic, nonwelded \\
to partially welded ash-flow tuff
\end{tabular} & $\begin{array}{l}\text { May be saturated but measured transmissivity } \\
\text { values are very low. May cause semi-perched } \\
\text { conditions. }\end{array}$ \\
\hline $\begin{array}{l}\text { Intra-caldera } \\
\text { intrusive confining } \\
\text { unit (IICU) }\end{array}$ & $\begin{array}{l}\text { Highly altered, highly } \\
\text { injected/intruded country rock } \\
\text { and granitic material }\end{array}$ & $\begin{array}{l}\text { Assumed to be impermeable. Conceptually } \\
\text { underlies each of the calderas in the southwest } \\
\text { Nevada volcanic field. Developed for the } \\
\text { PM-OV model to designate basement beneath } \\
\text { calderas as different from basement outside } \\
\text { calderas. }\end{array}$ \\
\hline $\begin{array}{c}\text { Granite confining } \\
\text { unit } \\
\text { (GCU) }\end{array}$ & Quartz monzonite & $\begin{array}{l}\text { Saturated at depth but because of low } \\
\text { intergranular porosity and permeability, plus the } \\
\text { lack of inter-connecting fractures, is considered } \\
\text { a confining unit. }\end{array}$ \\
\hline $\begin{array}{l}\text { Clastic confining } \\
\text { unit } \\
(\mathrm{CCU})\end{array}$ & Argillite, siltstone, quartzite & $\begin{array}{l}\text { Siliciclastic rocks are relatively impermeable; } \\
\text { coarser-grained siliciclastic rocks are fractured, } \\
\text { but with fracture porosity generally sealed due to } \\
\text { secondary mineralization. }\end{array}$ \\
\hline $\begin{array}{l}\text { Carbonate aquifer } \\
\text { (CA) }\end{array}$ & Dolomite, limestone & $\begin{array}{l}\text { Transmissivity values differ greatly and are } \\
\text { directly dependent on fracture frequency. }\end{array}$ \\
\hline
\end{tabular}


porosity and permeability, and these units are also considered aquifers where they are unaltered. The high matrix porosity and permeability of these rocks, particularly glassy nonwelded tuffs, make them susceptible to post-depositional alteration processes such as zeolitization, which can significantly reduce the permeability of altered rocks. Nonwelded tuff units that have undergone zeolitic or argillic alteration are considered confining units because of their very low permeability and generally poorly fractured character.

The UGTA CAU-scale hydrostratigraphic system differs in nomenclature from most of the previous, more regional studies and framework models (e.g., Winograd and Thordarson, 1975; Laczniak et al., 1996; and Belcher, 2004), which designated their main mapping/modeling units as HGUs. In the UGTA CAU-scale HFMs, the main modeling units are called HSUs, and HGUs are components of HSUs. Because lithologic composition typically exerts such a strong influence on a rock's porosity and permeability attributes, the UGTA CAU-scale hydrostratigraphic system, like those of Winograd and Thordarson (1975) and Laczniak et al. (1996), uses lithologic modifiers to designate HGUs.

\subsubsection{Alluvial HGUs}

Within the NTS area, alluvial deposits include two HGUs. The alluvial aquifer (AA; also an HSU) consists mainly of gravelly sand and sandy gravel eroded from the surrounding mountains during basin development, and deposited on alluvial fans by debris flow and sheet-flood processes (Figure 3-1). Similar deposits that filled the low moat area of the Timber Mountain caldera complex are also included in this HGU. Based on water production records from several water wells completed within the alluvial sediments at the NTS (e.g., Water Wells WW5c, WW5b,WWUE5c [Gillespie et al., 1996]), the AA is typically a fairly good aquifer.

Another HGU that is commonly associated with alluvial deposits is the playa confining unit (PCU). The PCU consists of silt and clay deposited in playa lakes that occupy the modern topographic low points of Yucca and Frenchman Flat (Figure 3-2). Older PCU deposits occur within the lower portions of the alluvial section beneath Frenchman Flat (BN, 2005).

\subsubsection{Volcanic HGUs}

The volcanic rocks within the NTS and vicinity are categorized into four HGUs based on primary lithologic properties, degree of fracturing, and secondary mineral alteration. In general, the altered volcanic rocks, which are typically zeolitized and support few fractures (Prothro, 2008), act as tuff confining units (TCUs) (Figure 3-3), and the unaltered rocks form aquifers. The aquifer units are further divided into welded-tuff aquifers (WTAs) and vitric-tuff aquifers 


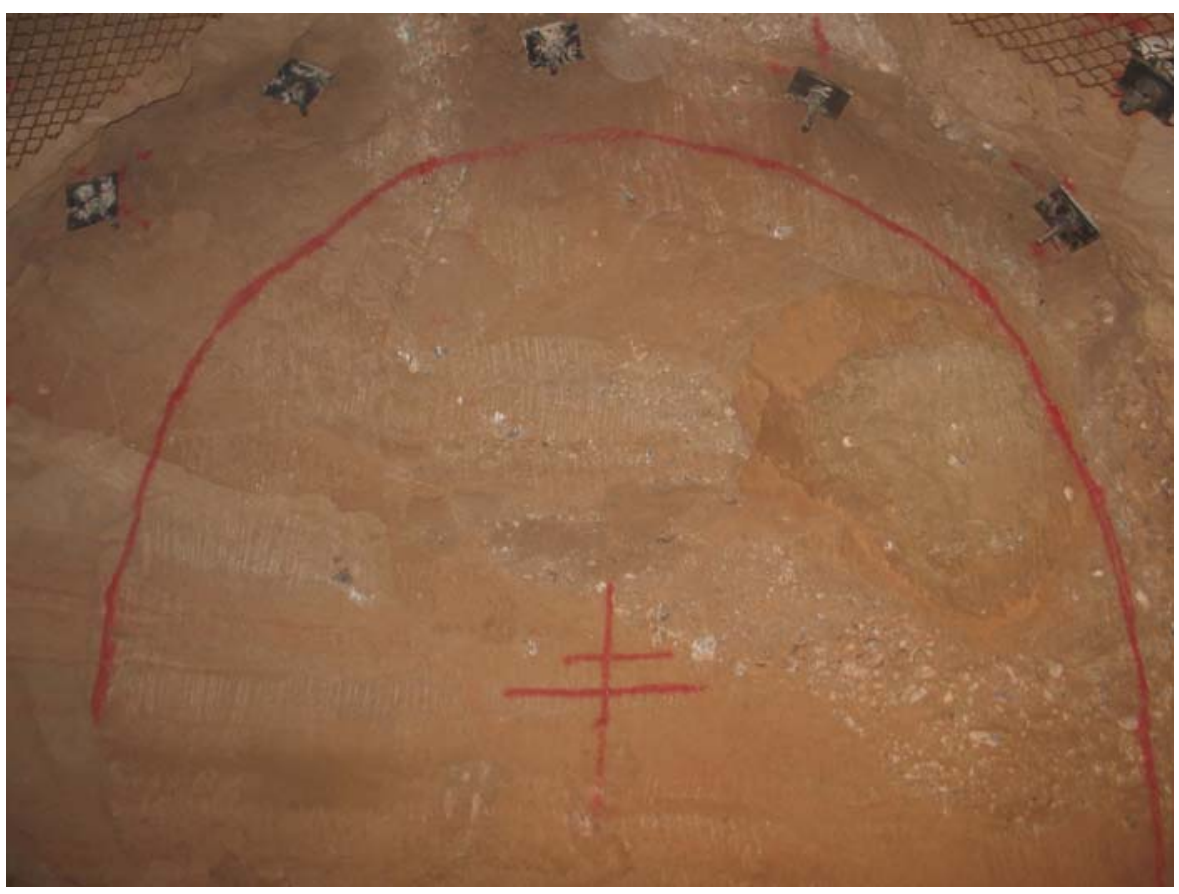

A. View of a mined face. (Red arc is approximately $3.3 \mathrm{~m}$ [10 ft] across at widest point.)

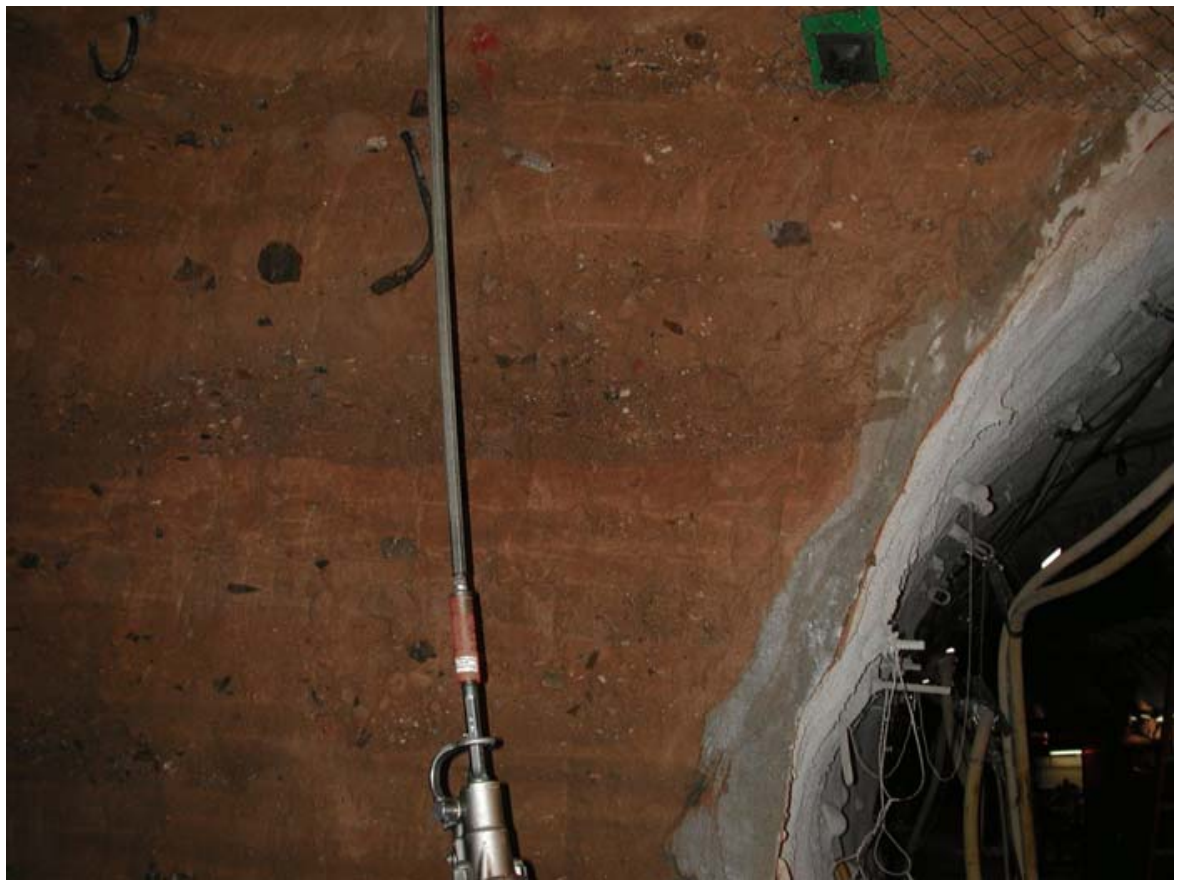

B. Closer view of alluvium (Jackleg drill is approximately $2.1 \mathrm{~m} \mathrm{[7} \mathrm{ft]} \mathrm{long.)}$

Figure 3-1

Photographs of Alluvium from the U1a Complex 


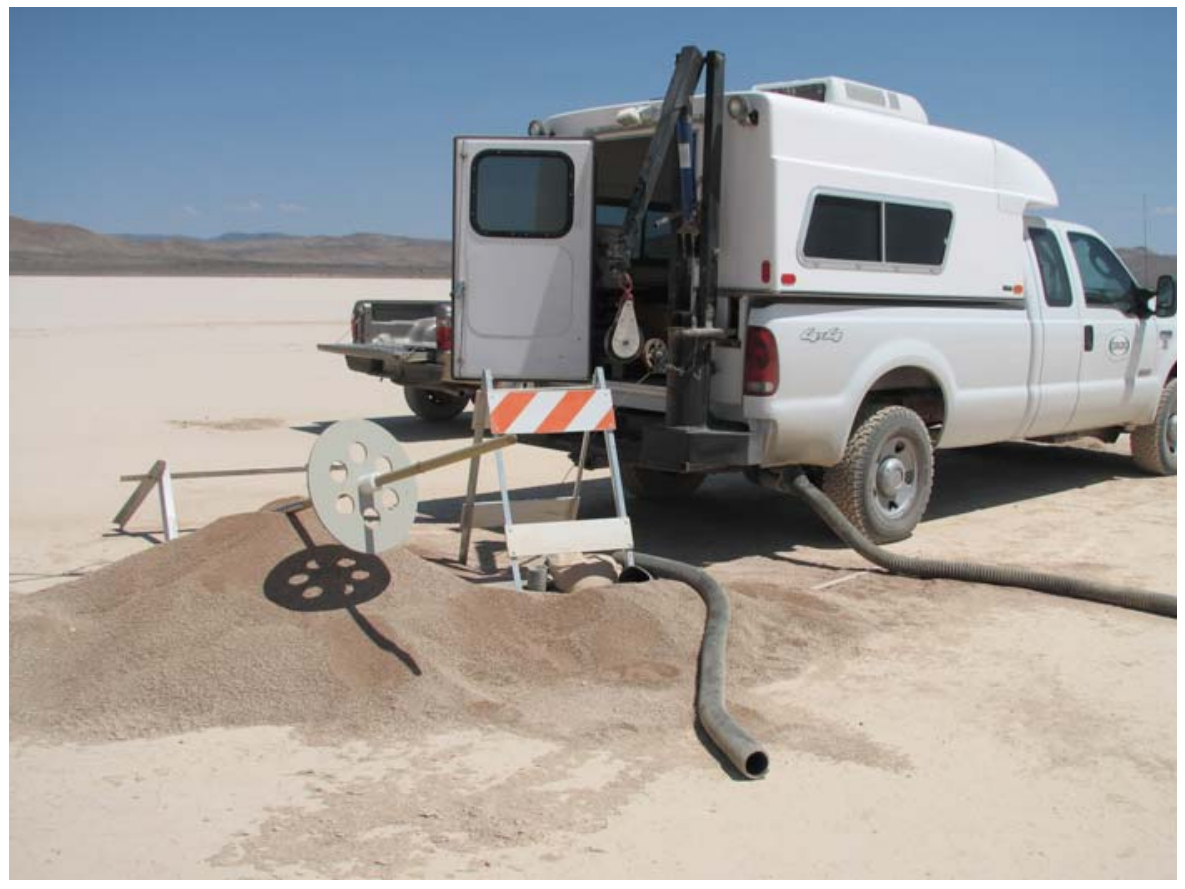

A. Geophysical Logging Truck on Yucca Lake Playa

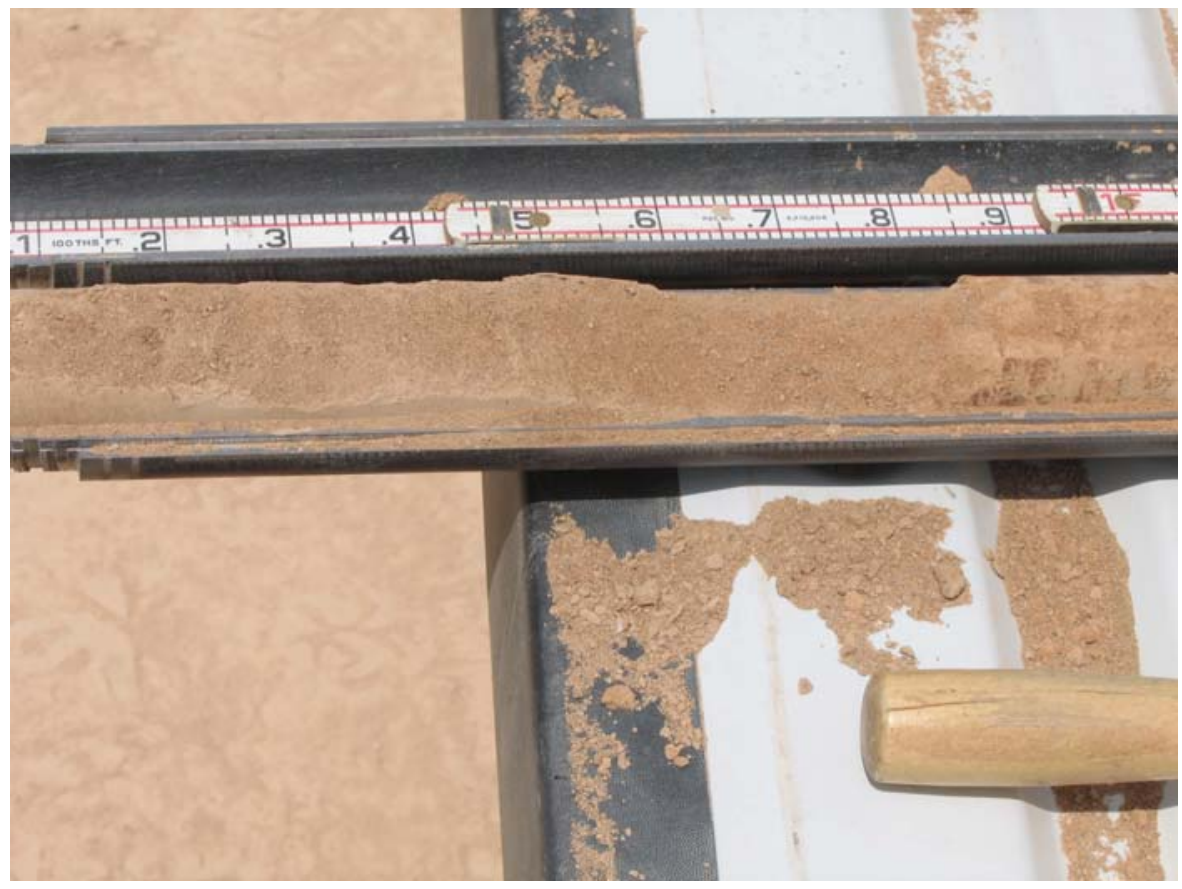

B. Playa Material Obtained During Drilling on the Yucca Lake Playa

Figure 3-2

Photographs of Yucca Lake Playa 


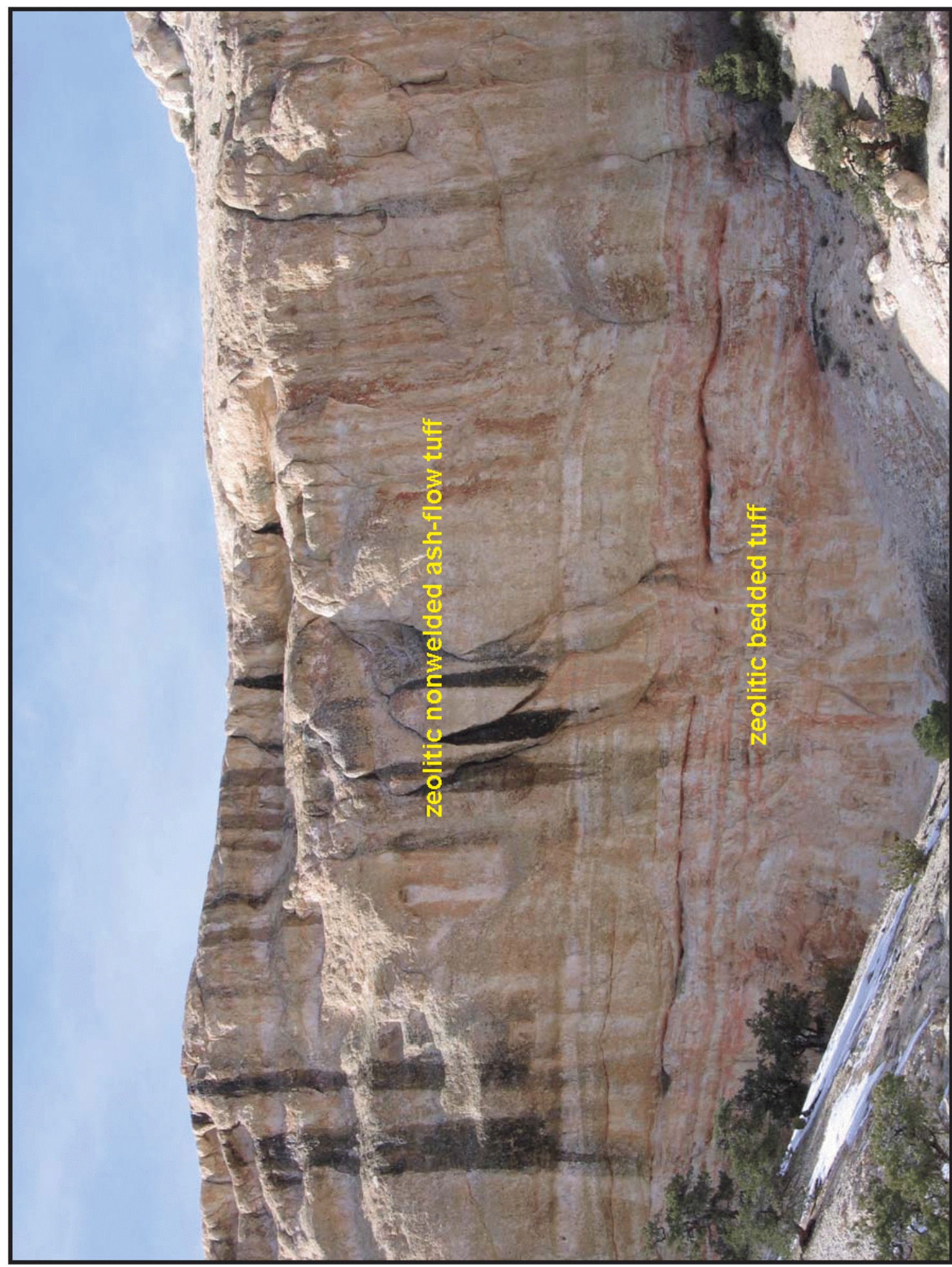

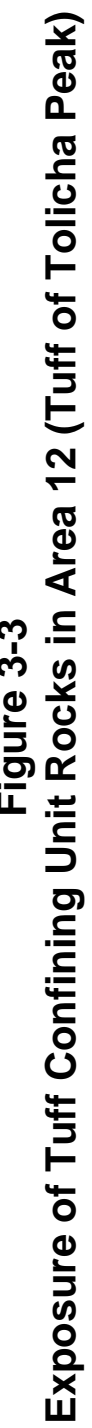


(VTAs) (depending on degree of welding) and lava-flow aquifers (LFAs) (Figures 3-4, 3-5, and 3-6). Denser rocks, such as welded ash-flow tuff and lava flows, tend to fracture more readily and, therefore, have relatively high permeability (Blankennagel and Weir, 1973; Winograd and Thordarson, 1975; Laczniak et al., 1996; IT, 1996a; Prothro and Drellack, 1997).

An additional igneous HGU, designated as the intra-caldera intrusive confining unit (IICU) was initially defined for the PM-OV model (BN, 2002). Conceptually, an IICU underlies each of the calderas in the southwest Nevada volcanic field. Although modeled as single intrusive masses, the exact nature of the rocks beneath the calderas is unknown, as no drill holes penetrate these rocks. It is assumed that these rocks range from highly altered, highly injected or intruded country rock to granite. The IICUs are considered to behave as confining units due to low primary porosity and low permeability where measured at other localities (such as in the granitic rocks of Climax stock [Walker, 1962]). Most fractures are probably filled with secondary minerals. The Climax stock in extreme northern Yucca Flat (Houser et al., 1961; Walker, 1962; Maldonado, 1977) and the Gold Meadows stock just north of Rainier Mesa (Snyder, 1977) may serve as analogs to the IICUs, though the effects of the greater depth of the IICUs cannot be addressed by these analogs.

\subsubsection{Pre-Tertiary HGUs}

The hydrogeology of the pre-Tertiary sedimentary rocks at the NTS follows the framework developed by Winograd and Thordarson (1975), which was used in the Phase I regional modeling effort (IT, 1996a; 1996b; 1996c) and subsequent CAU-scale models (BN, 2002; 2005; 2006; NSTec, 2007). Within the UGTA model areas, pre-Tertiary rocks are categorized as aquifer or confining unit HGUs based on lithology. The siliciclastic rocks, such as quartzite, siltstone, and shale, are classified as clastic confining units (Figure 3-7). The granitic intrusive rocks are classified as confining units (Figure 3-8). Carbonate rocks, such as limestone and dolomite, are classified as carbonate aquifers (Figure 3-9).

\subsection{Hydrostratigraphic Units}

The highest level within the UGTA CAU-scale hydrostratigraphic system is the HSU. HSUs are the main modeling unit within UGTA CAU-scale HFMs, and serve as 3-D bodies that are represented in the finite element mesh for the UGTA groundwater modeling process (IT, 1996d). HSUs are defined systematically by stratigraphically organizing HGUs of similar character into the larger HSU designations. HSUs typically consist of a single HGU (e.g., 100 percent TCU). However, some HSUs may consist of several HGUs, but are defined so that a single general type of HGU dominates (e.g., mostly WTA with minor VTA). In some places, thick stratigraphic intervals representing substantial volumes of rock contain a poorly understood distribution of

differing HGUs (e.g., LFA and TCU). These large intervals with uncertain distributions of 


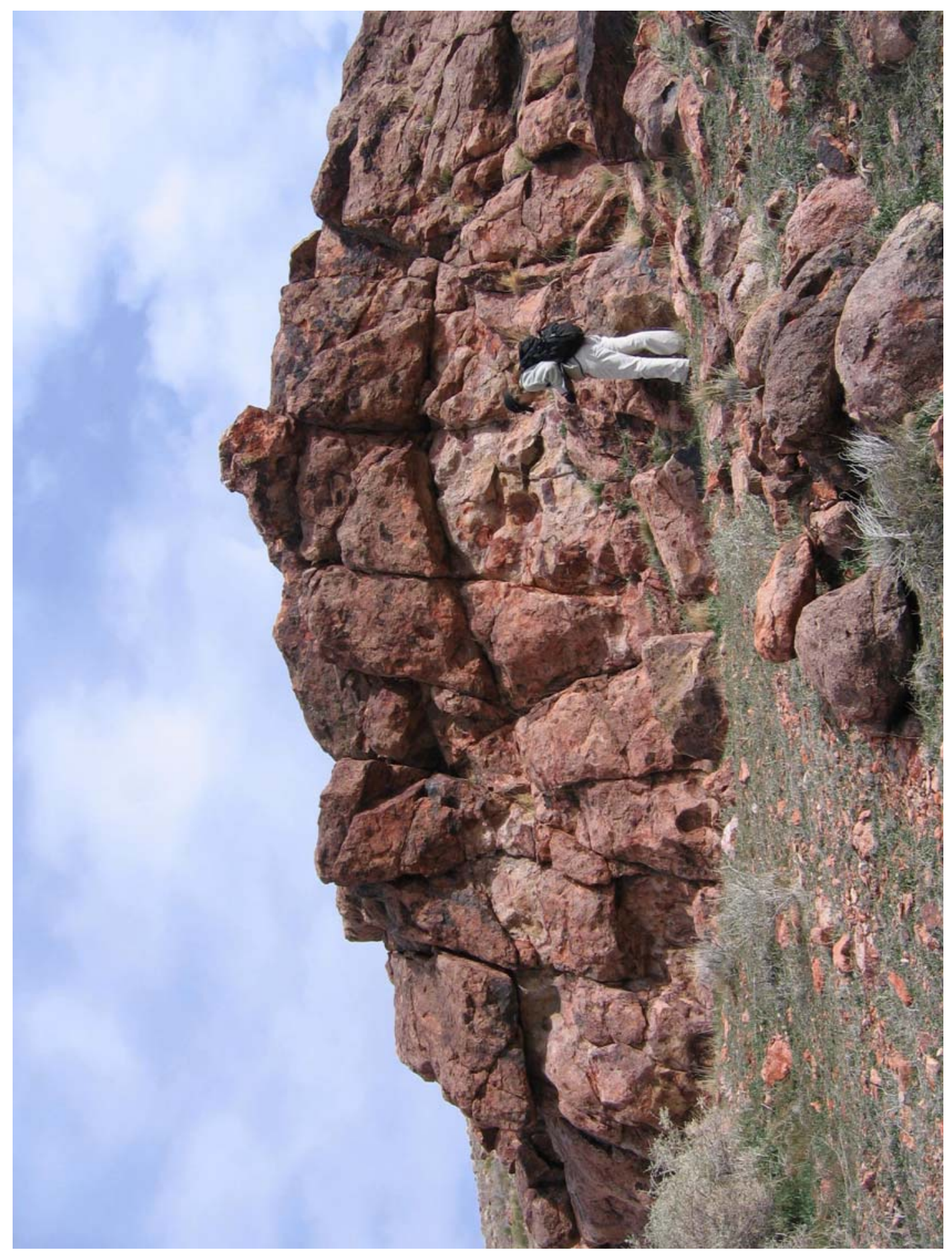

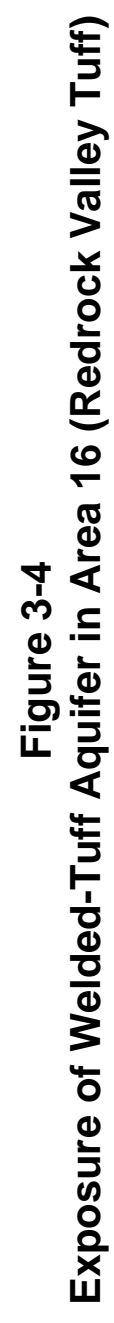




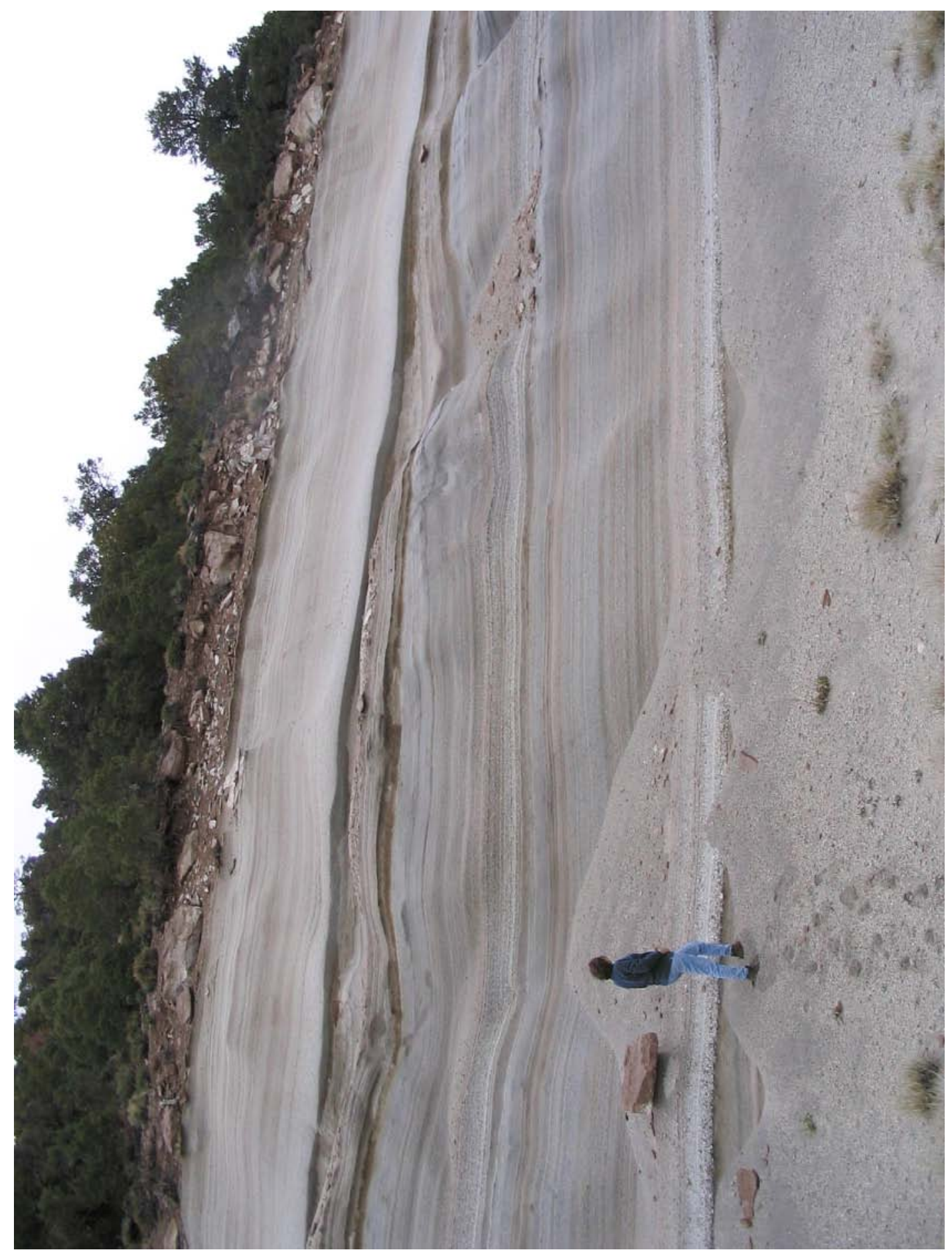

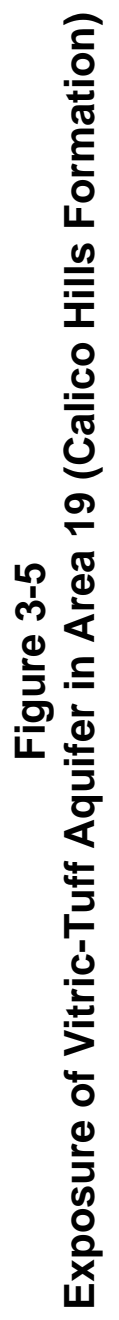




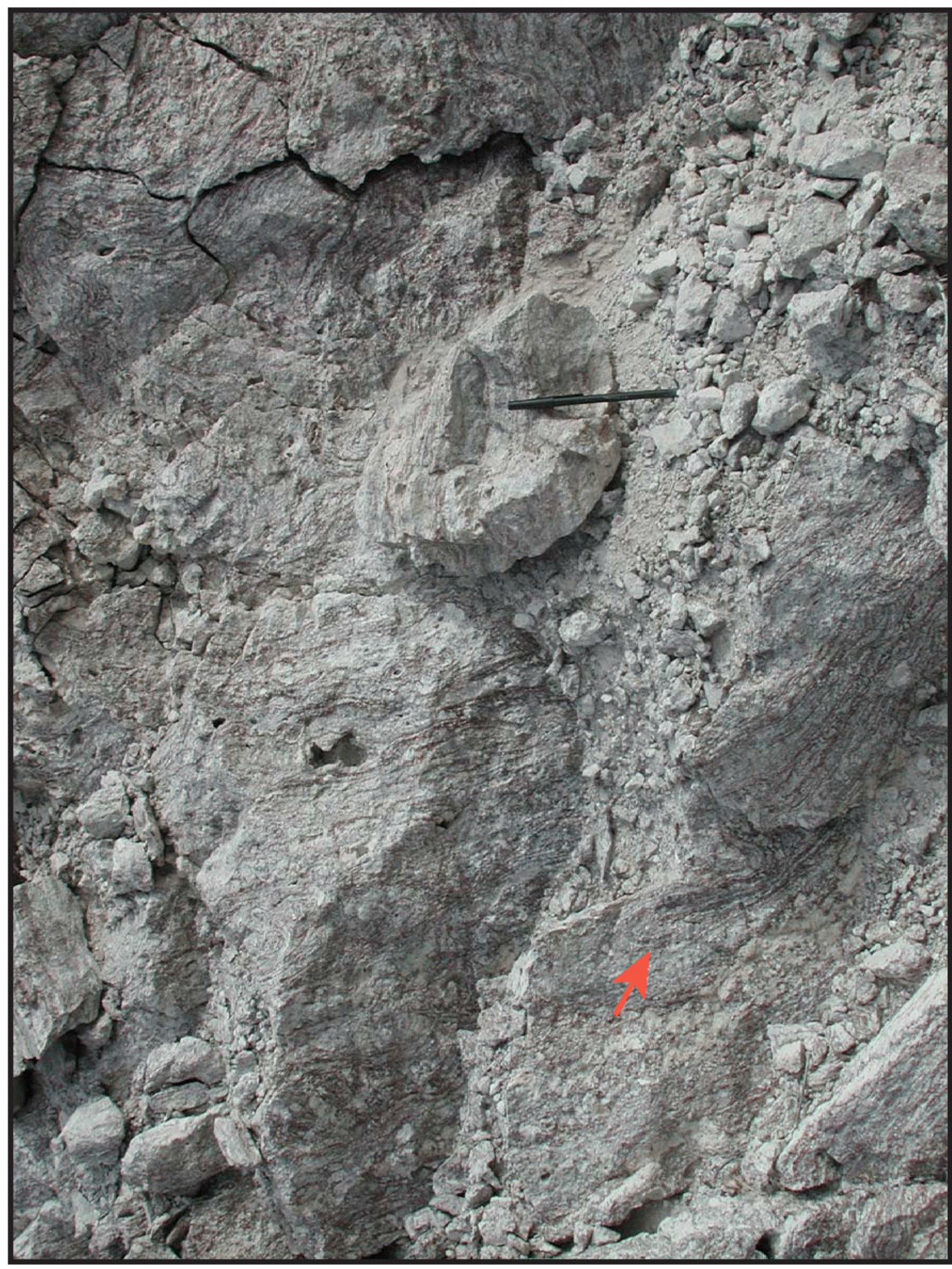

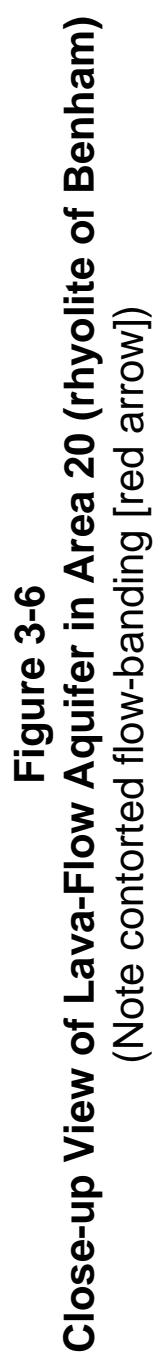




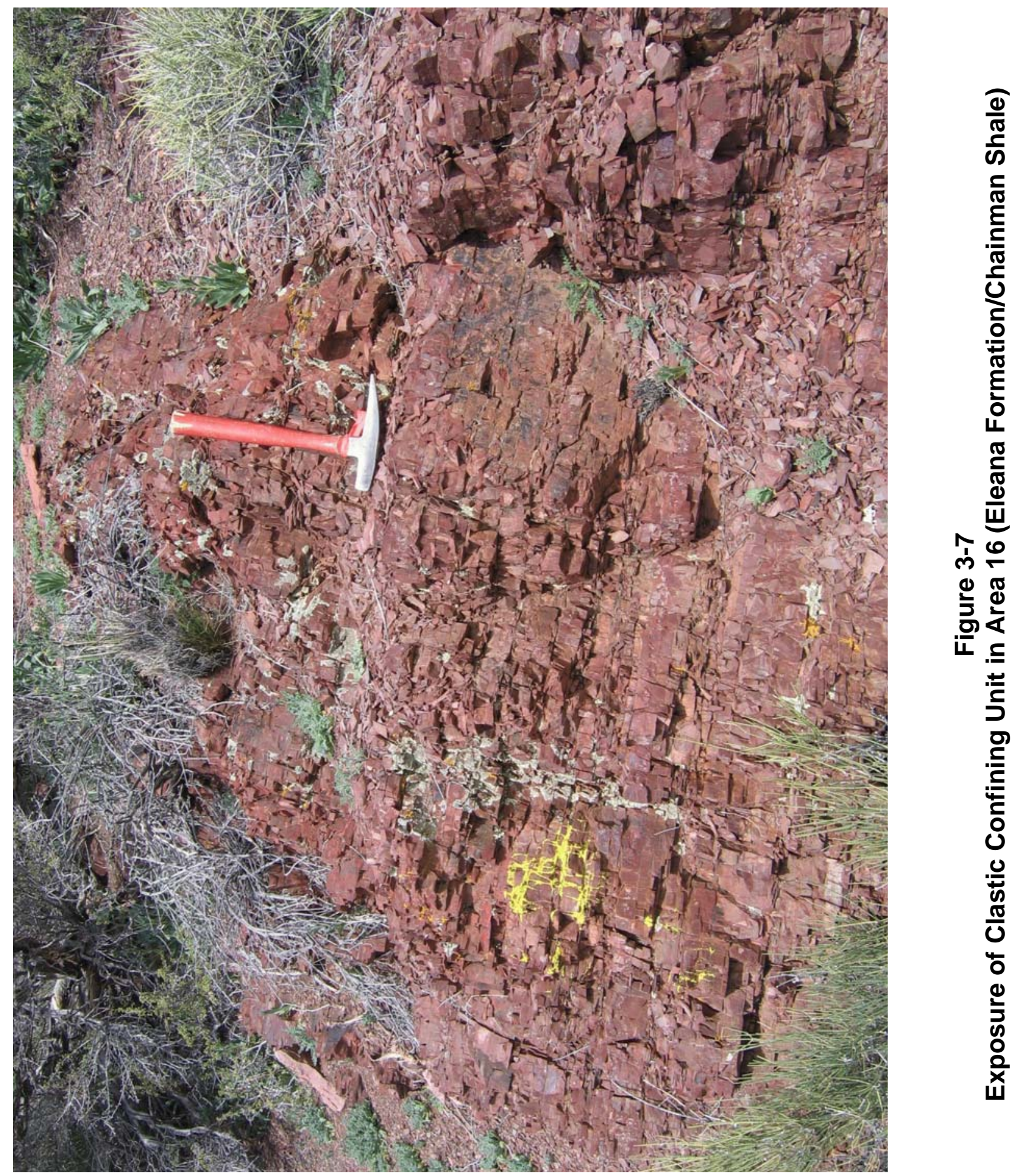




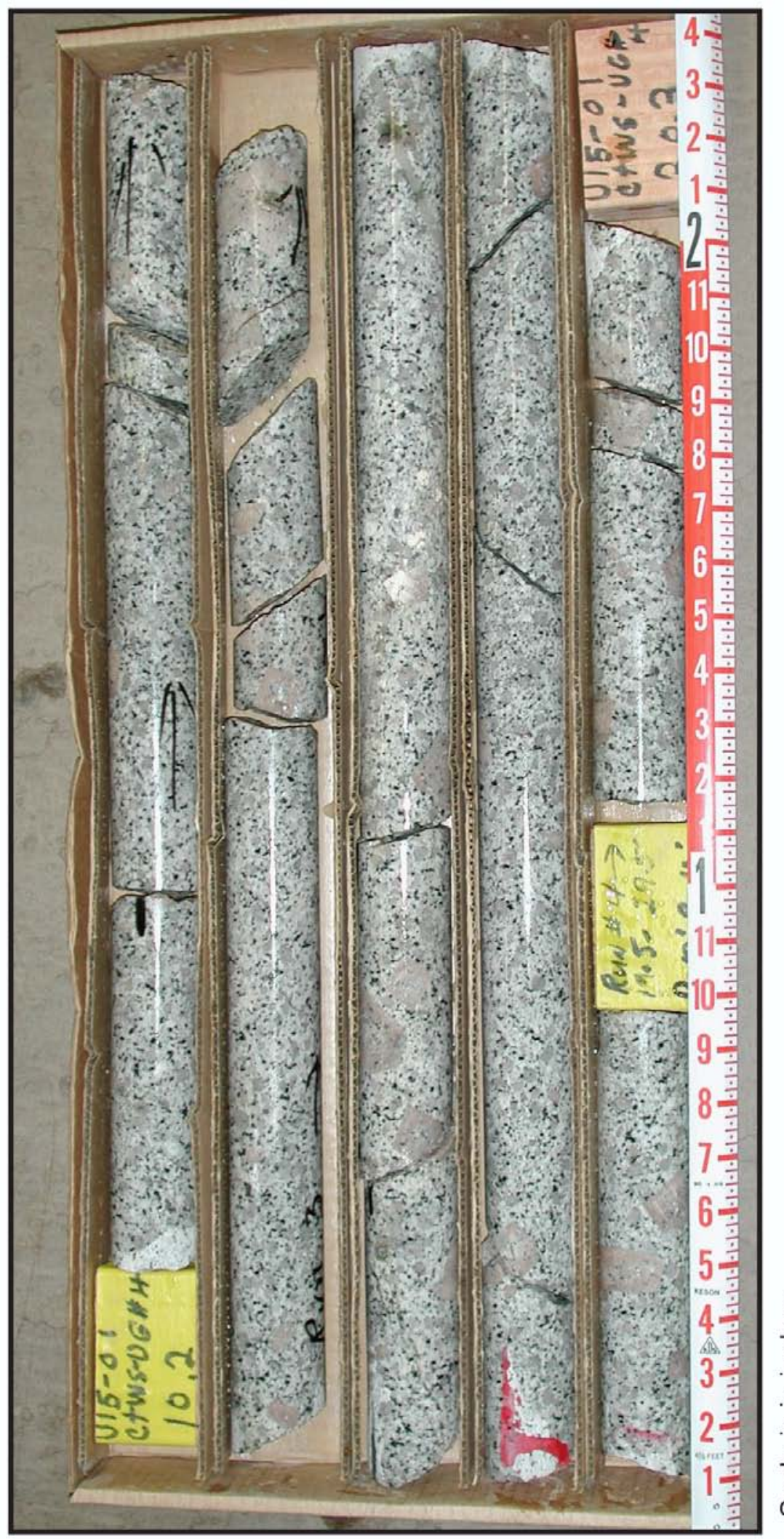

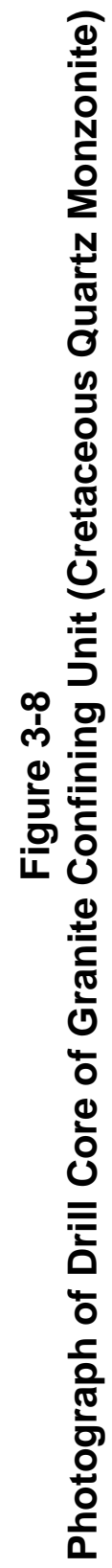




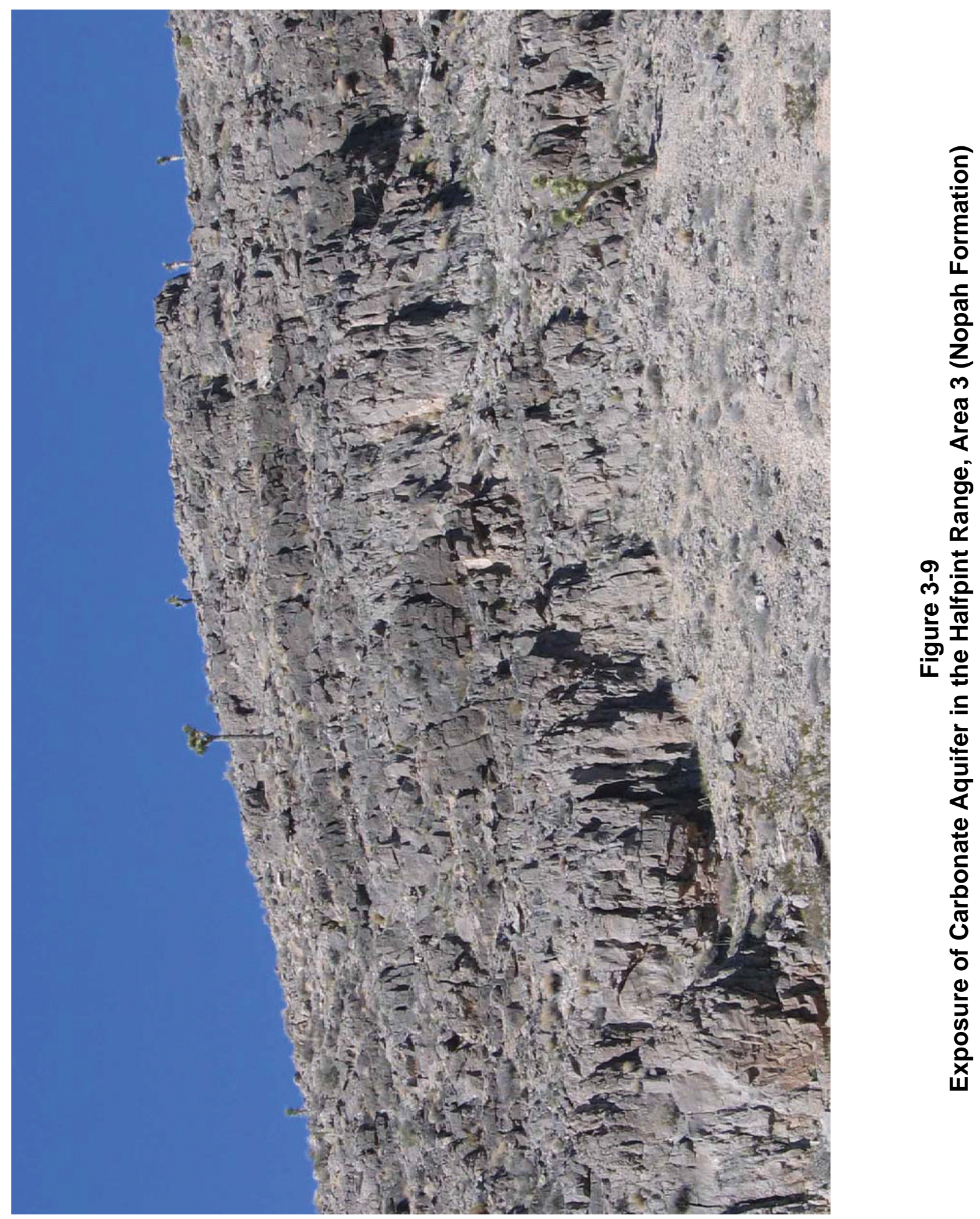


HGUs are called composite unit (CM) HSUs, and were originally developed as part of the PM-OV HFM (BN, 2002). This CM designation is similar to that of Maxey (1964) who recognized rock volumes that are a combination of aquifers and confining units. A more detailed discussion of CMs is provided in Section 3.2.2.5.

Currently, the UGTA CAU-scale hydrostratigraphic system consists of 76 HSUs, which are listed and described in Appendix A. Several additional HSUs were delineated for alternative models only. Because of the complex geologic setting of the NTS region, particularly the presence of dramatically different geologic domains (e.g., calderas and extensional basins), the cumulative number of HSUs has necessarily increased as each new CAU HFM was developed. However, the process used to develop and define HSUs for each HFM area has remained the same, resulting in a hydrostratigraphic system that maintains its integrity and is internally consistent without regard to model area. Table 3-2 shows the correlation of HSUs for the four CAU-scale HFMs. The information in Table 3-2 is also provided in graphical form in Plate 2.

Because the UGTA CAU-scale hydrostratigraphic system organizes rock units into HSUs according to the nature of a rock's porosity and permeability, the system and component HSUs are readily adaptable to groundwater flow models. However, radioactive contaminant transport modeling is also an important part of UGTA modeling efforts. Fortunately, HSUs are also adaptable to contaminant transport models.

An important aspect of UGTA transport models is the affinity of certain radionuclides to sorb onto specific minerals in the rocks (Tompson et al., 1999; Pawloski et al., 2000; Zavarin et al., 2004). These "reactive" minerals include clays, zeolites, hematite, carbonate, and certain mafic minerals such as biotite. Because mineralogic composition is a basic component of lithologic and stratigraphic designations and assignments, the hydrostratigraphic system can form the basis for developing reactive mineral models for transport modeling.

The volcanic rocks at the NTS are particularly conducive to development of reactive mineral models from HSUs. The presence of alteration minerals such as clays and zeolites is the main geologic characteristic used to distinguish TCUs from volcanic aquifers, which are composed mostly of non-reactive felsic minerals (i.e., WTA and LFA) and unaltered volcanic glass (i.e, VTA). Stratigraphic assignments of volcanic units are based on phenocryst mineralogy, including the amount of biotite present, and most volcanic units at the NTS can be characterized as either mafic-rich or mafic-poor according to their biotite content, which is typically an important attribute of a unit's stratigraphic identity. Carbonate is rarely present in volcanic rocks at the NTS, and occurs mainly within pre-Tertiary limestone and dolomite units where it 
Table 3-2

Correlation of Hydrostratigraphic Units Among the Four UGTA HFMs at the Nevada Test Site

\begin{tabular}{|c|c|c|c|c|c|c|}
\hline Hydrostratigraphic Unit & $\begin{array}{c}\text { RM-SM } \\
\text { Model }^{1,2} \\
\end{array}$ & $\begin{array}{c}\text { YF-CM } \\
\text { Model }^{1,3} \\
\end{array}$ & $\begin{array}{c}\text { Phase II FF } \\
\text { Model }^{1,4} \\
\end{array}$ & PM-OV Model ${ }^{1,5}$ & DVRFM $^{1,6}$ & \begin{tabular}{|c} 
UGTA Phase \\
11,7 \\
\end{tabular} \\
\hline Alluvial aquifer & AA & $\mathrm{AA} 2, \mathrm{AA} 1^{8}$ & $\begin{array}{c}\text { AA3, AA2, } \\
\text { AA1 }{ }^{7}\end{array}$ & AA & YAA & $A A^{9}$ \\
\hline Playa confining unit & \multirow{8}{*}{ NP ${ }^{10}$} & $\mathrm{PCU}$ & PCU2T & $\mathrm{NP}$ & YACU & \multirow{4}{*}{$N D, A A$} \\
\hline Basalt lava-flow aquifer & & BLFA & BLFA & YVCM & LFU & \\
\hline Older altered alluvial aquifer & & \multirow[b]{2}{*}{ NP } & OAA, OAA1 ${ }^{8}$ & & & \\
\hline Older playa confining unit & & & $\begin{array}{l}\text { PCU1U, } \\
\text { PCU1L }\end{array}$ & NP & $\mathrm{ND}^{12}$ & \\
\hline Younger volcanic composite unit & & NP (BLFA) ${ }^{14}$ & NP (BLFA) & YVCM & YVU & VU \\
\hline Thirsty Canyon volcanic aquifer & & \multirow{7}{*}{ NP } & \multirow{7}{*}{ NP } & TCVA & TMVA & TMA, VU \\
\hline Detached volcanic aquifer & & & & DVA & \multirow{2}{*}{ ND } & \multirow{2}{*}{ VU } \\
\hline Detached volcanic composite unit & & & & DVCM & & \\
\hline Fortymile Canyon composite unit & FCCM & & & FCCM & \multirow{6}{*}{ TMVA } & $\begin{array}{c}\text { TMA }^{9}, \mathrm{VA}^{9}, \\
\text { TC }\end{array}$ \\
\hline Fortymile Canyon aquifer & \multirow{3}{*}{ NP } & & & FCA & & VU \\
\hline Tannenbaum Hill lava-flow aquifer & & & & THLFA & & TMA \\
\hline Tannenbaum Hill composite unit & & & & THCM & & IIVIA \\
\hline Timber Mountain upper vitric-tuff aquifer & TM-UVTA $^{11}$ & TM-UVTA & ND & \multirow{2}{*}{ TMA $^{8}$} & & \multirow{7}{*}{ TMA, VA, TC } \\
\hline Timber Mountain welded-tuff aquifer & TM-WTA & TM-WTA & TM-WTA & & & \\
\hline Timber Mountain lower vitric-tuff aquifer & TM-LVTA & TM-LVTA & TM-LVTA & PVTA & TMVA, PVA & \\
\hline Fluorspar Canyon confining unit & \multirow{2}{*}{ NP } & \multirow{6}{*}{ NP } & \multirow{9}{*}{ NP } & FCCU & \multirow{2}{*}{ ND (TMVA) } & \\
\hline Windy Wash aquifer & & & & WWA & & \\
\hline Timber Mountain composite unit & TMCM & & & TMCM & \multirow{2}{*}{ TMVA } & \\
\hline Rainier Mesa breccia confining unit & RMBCU & & & ND (TMCM) & & \\
\hline Sub-caldera volcanic confining unit & SCVCU & & & SCVCU & OVU & $\mathrm{BCU}$ \\
\hline Benham aquifer & \multirow{2}{*}{ NP } & & & $\mathrm{BA}$ & ND (PVA) & \multirow{2}{*}{ TC } \\
\hline Upper Paintbrush confining unit & & NP (LTCU) & & UPCU & ND & \\
\hline Tiva Canyon aquifer & TCA & $\mathrm{NP}^{15}(\mathrm{TSA})$ & & TCA, $\mathrm{PCM}^{16}$ & \multirow{2}{*}{ PVA } & \multirow{2}{*}{ TMA, VA, TC } \\
\hline Paintbrush composite unit & NP & NP & & $\mathrm{PCM}$ & & \\
\hline
\end{tabular}


Table 3-2

Correlation of Hydrostratigraphic Units Among the Four UGTA HFMs at the Nevada Test Site (continued)

\begin{tabular}{|c|c|c|c|c|c|c|}
\hline Hydrostratigraphic Unit & $\begin{array}{c}\text { RM-SM } \\
\text { Model }^{1,2} \\
\end{array}$ & $\begin{array}{c}\text { YF-CM } \\
\text { Model }^{1,3} \\
\end{array}$ & $\begin{array}{c}\text { Phase II FF } \\
\text { Model }^{1,4} \\
\end{array}$ & PM-OV Model ${ }^{1,5}$ & DVRFM $^{1,6}$ & \begin{tabular}{|c|} 
UGTA Phase \\
1,7 \\
\end{tabular} \\
\hline Paintbrush vitric-tuff aquifer & PVTA & $\begin{array}{c}\text { NP } \\
(\text { TM-LVTA })\end{array}$ & TM-LVTA & PVTA & \multirow{5}{*}{ PVA } & \multirow{6}{*}{ TMA, VA, TC } \\
\hline Upper tuff confining unit & UTCU & UTCU & UTCU & UPCU, LPCU & & \\
\hline Paintbrush lava-flow aquifer & $\mathrm{NP}$ & NP & NP & PLFA & & \\
\hline Lower Paintbrush confining unit & NP (LTCU) & NP (LTCU) & NP (LTCU) & LPCU & & \\
\hline Topopah Spring aquifer & TSA & TSA & TSA & TSA, PCM ${ }^{15}$ & & \\
\hline Lower vitric-tuff aquifer & LVTA & LVTA & LVTA & PVTA & \multirow{6}{*}{$\begin{array}{l}\text { CHVA, } \\
\text { CHVU }\end{array}$} & \\
\hline Calico Hills vitric-tuff aquifer & CHVTA & $\begin{array}{l}\text { ND (TM-LVTA, } \\
\text { LVTA) }\end{array}$ & $\begin{array}{c}\text { ND } \\
\text { (TM-LVTA, } \\
\text { LVTA) }\end{array}$ & CHVTA & & \multirow{4}{*}{$\mathrm{TC}$} \\
\hline Calico Hills vitric composite unit & \multirow{2}{*}{ NP } & \multirow{2}{*}{ NP } & \multirow{2}{*}{ NP } & CHVCM & & \\
\hline Calico Hills zeolitic composite unit & & & & $\mathrm{CHZCM}$ & & \\
\hline Calico Hills confining unit & $\mathrm{NP}(\mathrm{LTCU})$ & NP (LTCU) & NP (LTCU) & $\mathrm{CHCU}$ & & \\
\hline Inlet aquifer & \multirow{3}{*}{ NP } & \multirow{3}{*}{ NP } & $\mathrm{NP}$ & $\mathrm{IA}$ & & TC, VA \\
\hline Wahmonie confining unit & & & WCU & NP & WVU & $\mathrm{BCU}^{9}$ \\
\hline Crater Flat composite unit & & & $\mathrm{NP}$ & CFCM & CHVA, & \multirow{2}{*}{$\mathrm{TC}, \mathrm{VU}$} \\
\hline Crater Flat confining unit & NP (LTCU) & NP (LTCU) & NP (LTCU) & CFCU & CHVU & \\
\hline $\begin{array}{l}\text { Yucca Mountain Calico Hills lava-flow } \\
\text { aquifer }\end{array}$ & YMCHLFA & \multirow{3}{*}{ NP } & \multirow{3}{*}{ NP } & ND (YMCFCM) & CHVU & \multirow{6}{*}{ VA, TC, VU } \\
\hline Yucca Mountain Crater Flat composite unit & NP & & & YMCFCM & ND & \\
\hline Kearsarge aquifer & $\mathrm{KA}$ & & & $\mathrm{KA}$ & CFPPA & \\
\hline Upper tuff confining unit 2 & UTCU2 & \multirow{3}{*}{$\begin{array}{l}\text { ND (LTCU or } \\
\text { TM-LVTA) }\end{array}$} & NP (LTCU) & $\mathrm{CHCU}$ & \multirow{5}{*}{ CFBCU } & \\
\hline Stockade Wash aquifer & SWA & & D & $\mathrm{ND}(\mathrm{CFCU}, \mathrm{BFCU})$ & & \\
\hline Lower vitric-tuff aquifer 2 & LVTA2 & & $N P$ & ND & & \\
\hline Bullfrog confining unit & BFCU & \multirow{2}{*}{ ND (LTCU) } & \multirow{2}{*}{ UTCU/LTCU } & BFCU & & \multirow{2}{*}{ TCB } \\
\hline Upper tuff confining unit 1 & UTCU1 & & & CFCU, BFCU & & \\
\hline
\end{tabular}


Table 3-2

Correlation of Hydrostratigraphic Units Among the Four UGTA HFMs at the Nevada Test Site (continued)

\begin{tabular}{|c|c|c|c|c|c|c|}
\hline Hydrostratigraphic Unit & $\begin{array}{c}\text { RM-SM } \\
\text { Model }^{1,2} \\
\end{array}$ & $\begin{array}{c}\text { YF-CM } \\
\text { Model }^{1,3} \\
\end{array}$ & $\begin{array}{l}\text { Phase II FF } \\
\text { Model }^{1,4} \\
\end{array}$ & PM-OV Model ${ }^{1,5}$ & DVRFM $^{1,6}$ & \begin{tabular}{|c|} 
UGTA Phase \\
11,7 \\
\end{tabular} \\
\hline Belted Range aquifer & BRA & BRA & NP & BRA & \multirow{5}{*}{ BRU } & \multirow[b]{2}{*}{ TBA, VA, TC } \\
\hline Lower vitric-tuff aquifer 1 & LVTA1 & ND (TM-LVTA) & $\begin{array}{c}\text { ND } \\
(\text { TM-LVTA) }\end{array}$ & NP & & \\
\hline Pre-Belted Range composite unit & OSBCU & OSBCU & LTCU/LTCU1 & PBRCM & & BAQ, BCU \\
\hline Belted Range confining unit & BRCU & BRCU & NP (LTCU) & \multirow{2}{*}{$\mathrm{NP}\left(\mathrm{PBRCM}{ }^{8}\right)$} & & \multirow{4}{*}{ TBA, VA, TC } \\
\hline Pre-Grouse Canyon Tuff lava flow aquifer & ND (BRA) & PRETBG & \multirow{3}{*}{ NP } & & & \\
\hline Tub Spring aquifer & TUBA & TUBA & & ND (BRA) & \multirow{8}{*}{ OVu $^{9}$} & \\
\hline Pre-Grouse Canyon Tuff lava flow aquifer 1 & NP & PRETBG $^{7}$ & & $\mathrm{NP}\left(\mathrm{PBRCM}^{8}\right)$ & & \\
\hline Lower tuff confining unit & LTCU & LTCU & \multirow{3}{*}{$\begin{array}{l}\text { LTCU, } \\
\text { LTCU1 }^{7}\end{array}$} & $\begin{array}{l}\text { CFCU, BFCU, } \\
\text { PBRCM }\end{array}$ & & \multirow{5}{*}{ VCU, BCU } \\
\hline Oak Spring Butte confining unit & OSBCU & OSBCU $^{12}$ & & \multirow{4}{*}{$\mathrm{ND}\left(\mathrm{PBRCM}^{8}\right)$} & & \\
\hline Redrock Valley aquifer & RVA & ND $\left(\mathrm{OSBCU}{ }^{12}\right)$ & & & & \\
\hline Redrock Valley breccia confining unit & RVBCU & NP & NP & & & \\
\hline Lower tuff confining unit 1 & LTCU1 & $\begin{array}{l}\text { ND (LTCU/ } \\
\text { OSBCU) }\end{array}$ & $\begin{array}{l}\text { LTCU, }_{7} \\
\text { LTCU1 }^{7}\end{array}$ & & & \\
\hline $\begin{array}{l}\text { Twin Peaks aquifer } \\
\text { (RM-SM alternative model only) }\end{array}$ & TPA & NP (OSBCU) & NP & PBRCM & & VCU, BCU \\
\hline Argillic tuff confining unit & ATCU & ATCU & ND (LTCU) & ND (PBRCM) & VSU, OVU & \multirow{2}{*}{$\mathrm{BCU}$} \\
\hline Volcaniclastic confining unit & \multirow{2}{*}{ NP } & VCU & VCU & NP & VSU & \\
\hline Black Mountain intrusive confining unit & & \multirow{6}{*}{ NP } & \multirow{6}{*}{ NP } & BMICU & \multirow{6}{*}{$\mathrm{ICU}$} & VU \\
\hline Ammonia Tanks intrusive confining unit & ATICU & & & ATICU & & \multirow{2}{*}{ BCU, TMA } \\
\hline Rainier Mesa intrusive confining unit & RMICU & & & RMICU & & \\
\hline Claim Canyon intrusive confining unit & NP & & & $\mathrm{CCICU}$ & & VA \\
\hline Calico Hills intrusive confining unit & $\mathrm{CHICU}$ & & & $\mathrm{CHICU}$ & & $\mathrm{BCU}, \mathrm{I}$ \\
\hline Silent Canyon intrusive confining unit & SCICU & & & SCICU & & BCU, LCCU \\
\hline
\end{tabular}


Table 3-2

Correlation of Hydrostratigraphic Units Among the Four UGTA HFMs at the Nevada Test Site (continued)

\begin{tabular}{|c|c|c|c|c|c|c|}
\hline Hydrostratigraphic Unit & $\begin{array}{c}\text { RM-SM } \\
\text { Model }^{1,2} \\
\end{array}$ & $\begin{array}{c}\text { YF-CM } \\
\text { Model }^{1,3} \\
\end{array}$ & $\begin{array}{l}\text { Phase II FF } \\
\text { Model }^{1,4}\end{array}$ & PM-OV Model ${ }^{1,5}$ & DVRFM $^{1,6}$ & $\begin{array}{c}\text { UGTA Phase } \\
1_{1,7} \\
\end{array}$ \\
\hline Redrock Valley intrusive confining unit & RVICU & NP & \multirow{3}{*}{ NP } & NP & \multirow{2}{*}{$\mathrm{ICU}$} & $\mathrm{BCU}$ \\
\hline Mesozoic granite confining unit & MGCU & MGCU & & MGCU & & I \\
\hline Lower clastic confining unit 1-thrust plate & LCCU1 & LCCU1 & & LCCU1 & LCCU_T1 & NP (LCCU1) \\
\hline Lower carbonate aquifer-thrust plate & LCA3 & LCA3 & LCA3 & LCA3 & LCA_T1 & LCA3 \\
\hline Upper clastic confining unit-thrust plate & UCCU1 & NP & \multirow{4}{*}{ NP } & \multirow{4}{*}{ NP } & & \multirow{3}{*}{ NP } \\
\hline $\begin{array}{l}\text { Lower carbonate aquifer-thrust plate } 1 \\
\text { (RM-SM alternative model only) }\end{array}$ & LCA3-1 & NP & & & NP & \\
\hline Lower clastic confining unit 2-thrust plate & LCCU2 & LCCU2 & & & LCCU_T1 & \\
\hline Upper carbonate aquifer & UCA & UCA & & & UCA & LCA3 \\
\hline Upper clastic confining unit & UCCU & UCCU & UCCU & UCCU & UCCU & UCCU \\
\hline Lower carbonate aquifer & LCA & LCA & LCA & LCA & LCA & LCA \\
\hline Lower clastic confining unit & LCCU & LCCU & LCCU & LCCU & LCCU & LCCU \\
\hline
\end{tabular}

1 If correlative to more than one HSU, all HSUs are listed.

2 See NSTec (2007) for explanation of RM-SM HSU nomenclature.

3 See BN (2006) for explanation of YF-CM model nomenclature.

4 See BN (2005) for explanation of Frenchman Flat HSU nomenclature.

5 See BN (2002) for explanation of PM-OV HSU nomenclature.

6 See Belcher (2004) for explanation of the Death Valley Regional Flow Model.

7 See IT (1996a) for explanation of the UGTA Phase I HSU nomenclature.

8 Subdivisions, though hydrogeologically equivalent, are necessary to satisfy operational requirements of the EarthVision ${ }^{\circledR}$ modeling software.
9 Not subdivided.

10 Not present.

11 Subdivided only in Yucca Flat and Mid Valley.

12 Not differentiated.

13 Subdivided only in areas with sufficient drill hole control.

14 Parentheses implies a less than 1:1 correlation.

15 The welded Tpc (TCA) was lumped with the TSA in Mid Valley in the YF-CM model.

16 Paintbrush units differentiated in the SCCC area, but lumped in the vicinity of Yucca Mountain. 
composes the majority of the mineralogy. Thus, it has been relatively easy to create reactive mineral models used in contaminant transport modeling from the previously defined UGTA HSUs (Stoller-Navarro Joint Venture, 2005; 2007; 2008).

\subsubsection{Methodology for Delineating Hydrostratigraphic Units}

The delineation of HSUs in the NTS region, particularly at the CAU scale, is complicated by the large number of stratigraphic units, great variety of rock types, and complex depositional and structural histories. Fortunately for the UGTA CAU-scale modeling project, the delineation of the various aquifers and confining units (i.e., HGUs) at the NTS was generally established prior to the UGTA Sub-Project by Winograd and Thordarson (1975). Thus, the development of the CAU-scale hydrostratigraphic system began with most of the HGUs already established on which to begin defining and mapping HSUs for HFM construction.

The process for delineating HSUs begins with the collection and review of geologic and geophysical information of a particular area to determine the various rock types present. Using mainly the geologic quadrangle maps and drill hole information, all the rock types are categorized as one of the ten HGUs of the UGTA CAU-scale hydrostratigraphic system (Table 3-1). These are based mainly on each rock type's primary lithology, type and degree of post-depositional alteration, and propensity to fracture, which typically relate directly to the nature of a rock's interstices (i.e., porosity and permeability). For example, all occurrences of welded ash-flow tuff in an area are categorized as WTAs because these brittle rocks typically have relatively low matrix porosity and permeability, but tend to be fractured as a result of cooling and tectonic forces. In contrast, all zeolitic tuffs in the area are categorized as TCU HGUs because the nature of their interstices is rather unique and considerably different from WTAs, consisting of relatively high total porosity but low permeability. TCUs also tend to be poorly fractured.

Once the rocks of an area have been categorized into HGUs, stratigraphic information is used to organize the various HGUs into internally consistent, correlatable, and mappable unit volumes, or HSUs. HSUs are typically designated by a stratigraphic name followed by an HGU category. For example, the Paintbrush vitric-tuff aquifer HSU is composed of vitric (i.e., glassy and unaltered) nonwelded tuffs of the Paintbrush Group stratigraphic unit. Where an HSU includes HGUs of more than one stratigraphic unit, a relative position name is sometimes used in place of a stratigraphic name. The lower tuff confining unit (LTCU), for example, consists of a rather monotonous sequence of zeolitic nonwelded tuffs in the lower portion of the volcanic section 
that includes numerous stratigraphic units, but which all consist of TCU HGUs. Figure 3-10 illustrates the delineation of HSUs using geologic quadrangle maps. The delineation of HSUs in a drill hole is illustrated in Figure 3-11. Additional examples of the delineation of HSUs in UGTA wells are provided in Appendix B.

The importance of integrating stratigraphic information in the delineation of HSUs cannot be overstated. The complex geologic setting of the NTS region coupled with the higher resolution of CAU-scale HFMs necessitates the careful integration of stratigraphic information to assure that HSUs properly correlate throughout each of the four HFMs. Also, because several HFM areas overlap, it is important that the integration of stratigraphic information was consistently applied during development of each HFM. Plate 2 illustrates the correlation between stratigraphy and hydrostratigraphy for various domains across all four UGTA HFMs. For comparison and correlation to important regional models and studies, Plate 2 also includes correlation columns for the Death Valley Regional Flow Model (Belcher, 2004) and the foundation hydrogeologic work of Winograd and Thordarson (1975). These regional studies applied more general stratigraphic information in delineating their main mapping/modeling units, which they referred to as HGUs. Although appropriate for such regional hydrologic studies, it is insufficient for the smaller-scale CAU models, particularly in such a complex geologic setting.

The importance of accurately integrating detailed rock- and time-stratigraphic information into the development of the UGTA CAU-scale hydrostratigraphic system is illustrated in simplified form in Figure 3-12. In the southwestern portion of Pahute Mesa, two WTAs separated by a TCU are present between approximately 1,000 and 1,300 m (3,280 and 4,260 ft) elevation (BN, 2002). The two welded ash-flow tuff units (Tiva Canyon Tuff and Topopah Spring Tuff) that form these two WTAs are very similar in appearance and basic mineralogy. Because ash-flow tuffs typically form extensive sheet-like deposits, these WTAs should form continuous tabularshaped bodies beneath this portion of Pahute Mesa, unless disrupted by faulting. Thus, it is critical that these two HGUs are correlated to the correct stratigraphic position between the various drill holes in the area so that they can be correctly assigned as separate, mappable HSUs.

Figure 3-12A illustrates the problem of using hydrogeologic information only. As shown here, important questions arise as to the proper relationships between the WTAs encountered in drill holes PM-3 and UE-20c. This is important because the nature of ash-flow tuff geometry suggests that one of the WTAs in UE-20c probably correlates with the WTA in PM-3, thus forming a continuous flow path between the two holes. By integrating stratigraphic information, 

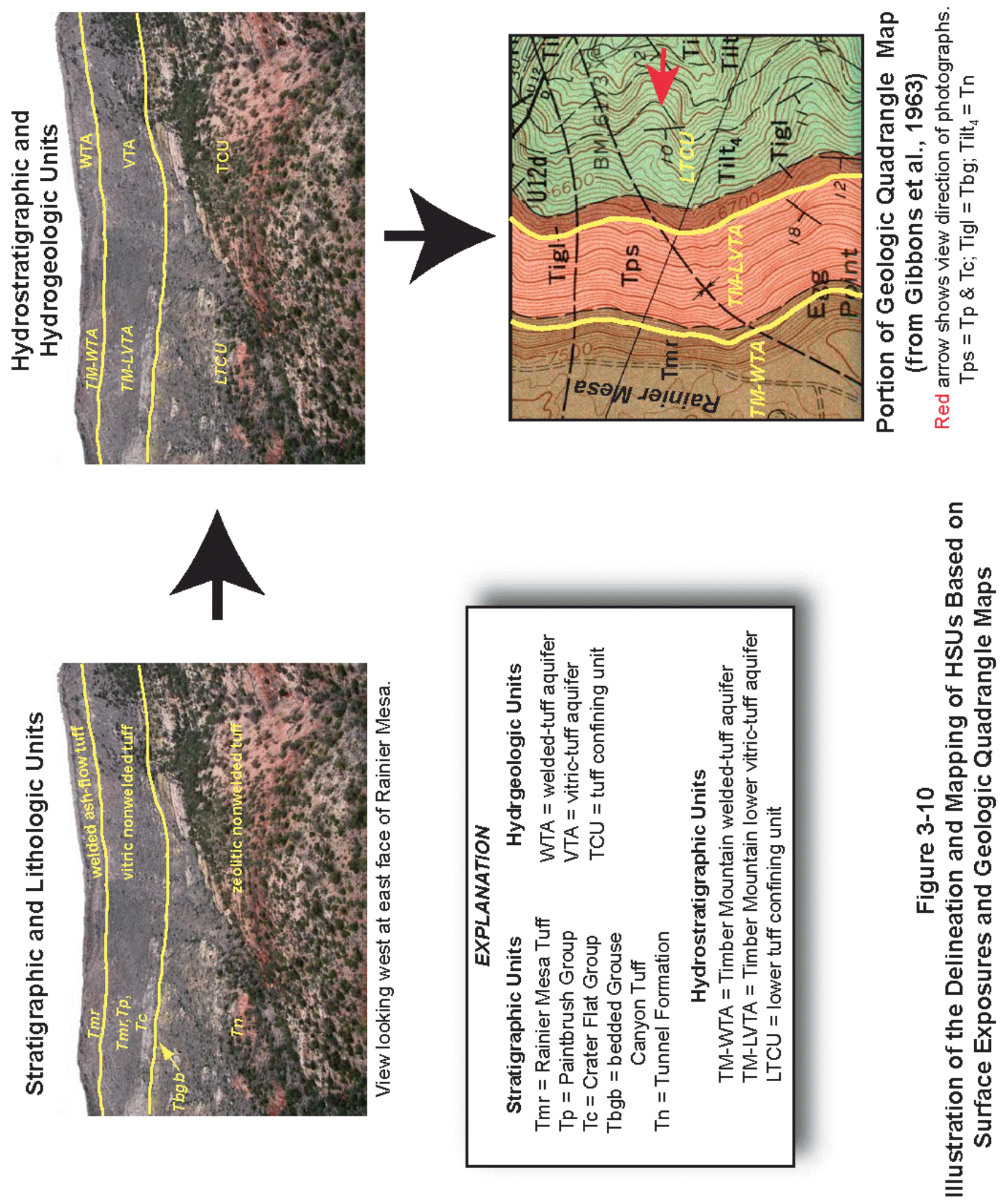


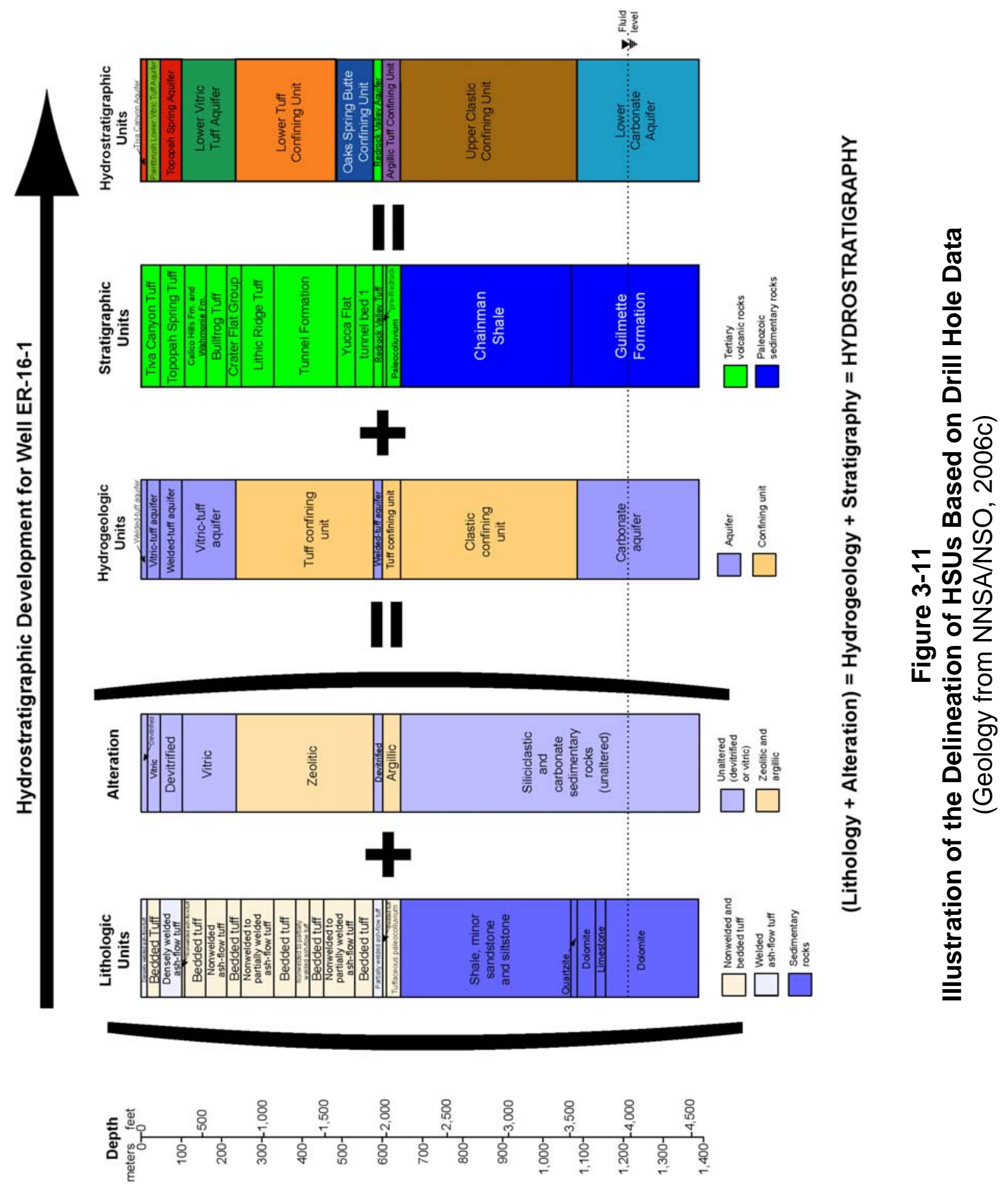




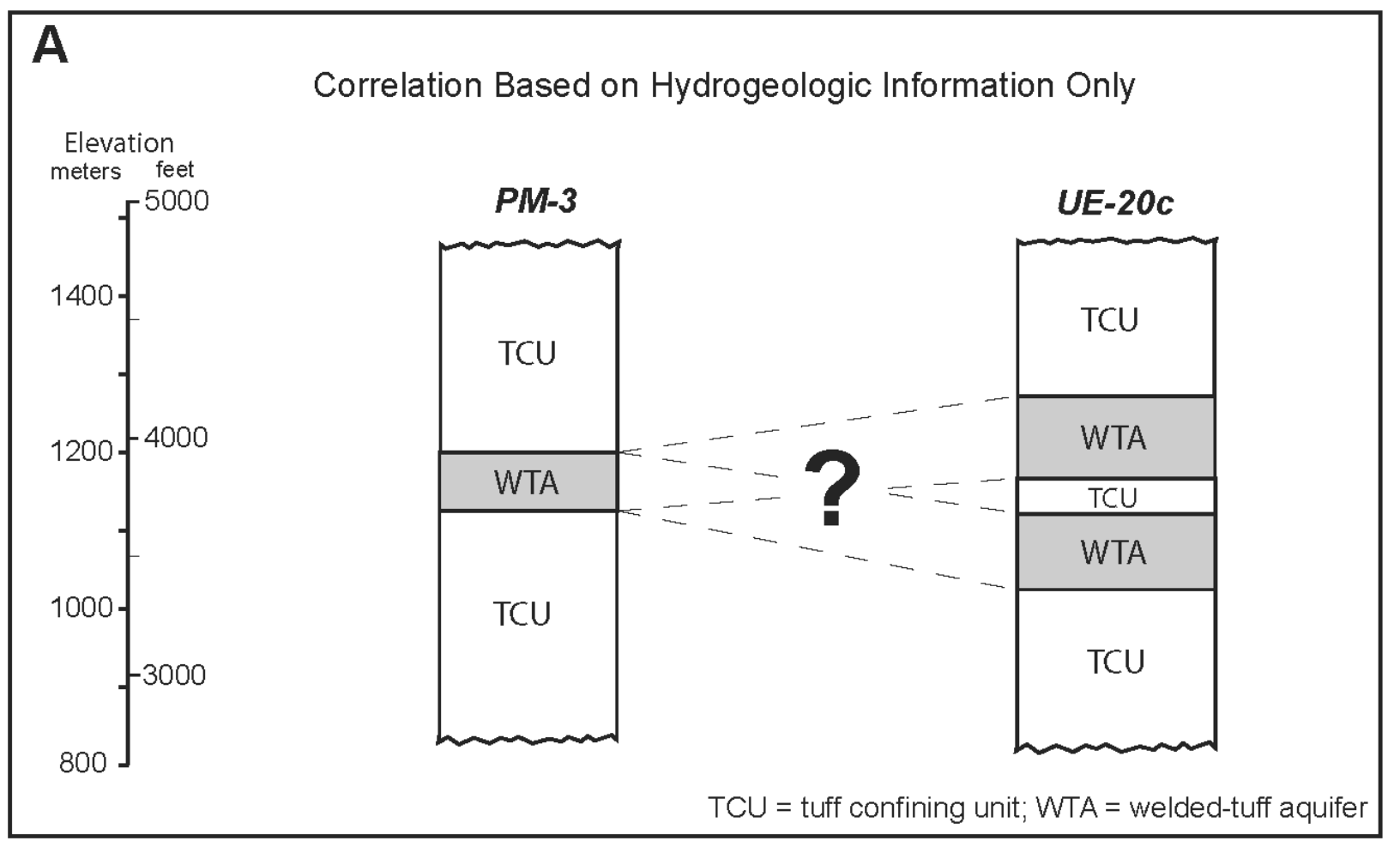

\section{B}

\section{Correlation and Hydrostratigraphic Unit Delineation}

Based on Both Hydrogeologic and Stratigraphic Information
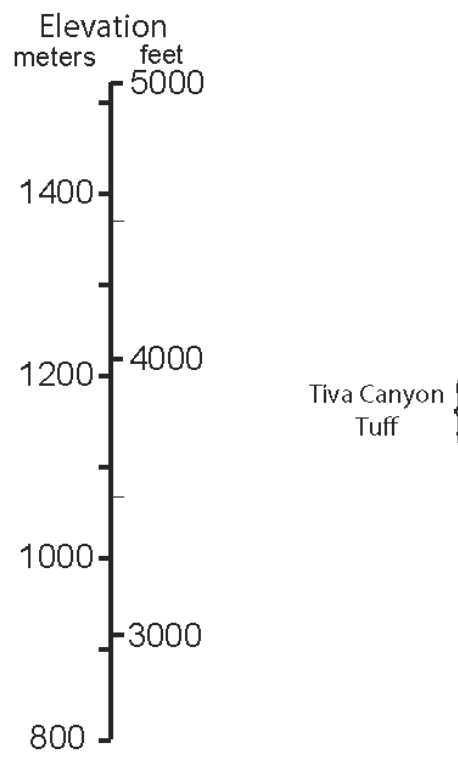

PM-3

UE-20c

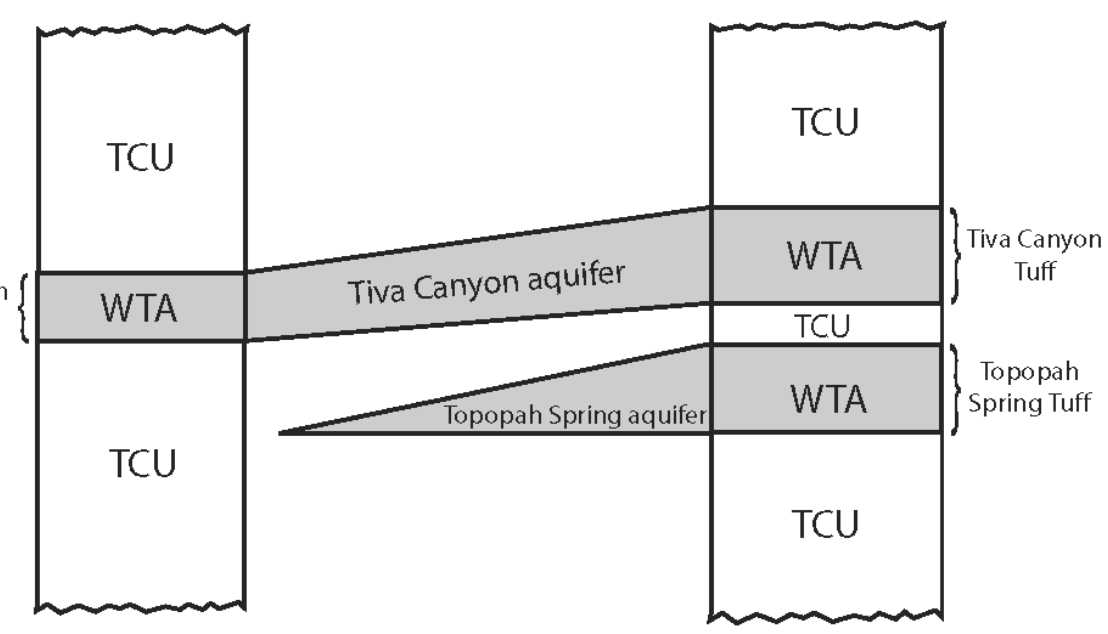

Stratigraphic units from Warren et al. (2003)

Figure 3-12

Schematic Cross Sections that Illustrate the Importance of Integrating Stratigraphic Information in the Correlation and Delineation of HSUs 
however, it is revealed that the two WTAs in UE-20c are, from higher to lower, the Tiva Canyon Tuff and the Topopah Spring Tuff, both stratigraphic formations of the Paintbrush Group (Warren et al., 2003). The WTA in PM-3 is the Tiva Canyon Tuff, and thus the upper WTA in UE-20c correlates to the WTA in PM-3 and forms the Tiva Canyon aquifer HSU (Figure 3-12B). Consequently, the lower WTA in UE-20c, designated the Topopah Spring aquifer HSU, must end (i.e., pinch-out) somewhere between the two holes. These important relationships could not be confidently deciphered without the integration of the detailed stratigraphic information.

Relying too heavily on stratigraphic information, and not incorporating lithologic and alteration information when defining HSUs, however, can also lead to poor or questionable correlations and HSU assignments. For example, the Grouse Canyon Tuff stratigraphic unit forms conspicuous exposures of densely welded ash-flow tuff (i.e., WTA) in the vicinity of Rainier Mesa, near its source area (Gibbons et al., 1963; Barnes et al., 1963). Yet at its distal edges, beneath most of Yucca Flat, the Grouse Canyon Tuff consists only of vitric and zeolitic nonwelded ash-flow tuff and bedded tuff, forming either a VTA or a TCU (BN, 2002). Problems are obvious in accurately modeling groundwater flow within, for example, a "Grouse Canyon” HSU, if only stratigraphic information were utilized for establishing the HSU. A similar situation occurs with the Tub Spring Tuff, which also consists of densely welded ashflow tuff (i.e., WTA) in the extreme northern portions of Yucca Flat (Barnes et al., 1963; 1965), but is mostly zeolitic bedded tuff (i.e., TCU) in other portions of the basin (BN, 2006).

\subsubsection{Hydrostratigraphic Complexities}

The complex geologic setting of the NTS region naturally results in complex hydrostratigraphic relationships that can be difficult to represent realistically in CAU-scale HFMs, particularly in areas of sparse data control and with certain constraints imposed by software requirements. The following sections discuss several of these complexities.

\subsubsection{Changes in Lithofacies}

Changes in lithologic features within certain volcanic deposits in the NTS region can result in distinct lithofacies with significantly different hydrologic properties, as illustrated in the examples of the Grouse Canyon and Tub Spring tuffs above. If of significant thickness and extent, these lithofacies are typically categorized as separate HGUs and are included in different HSUs. For example, ash-flow tuff deposits typically have several associated lithofacies related to the degree of welding that occurred after emplacement of the ash-flow tuff (Smith, 1960). Figure 3-13 schematically shows a typical welding profile of an ash-flow tuff deposit. As shown here, the degree of welding tends to decrease outward both vertically and laterally from the 

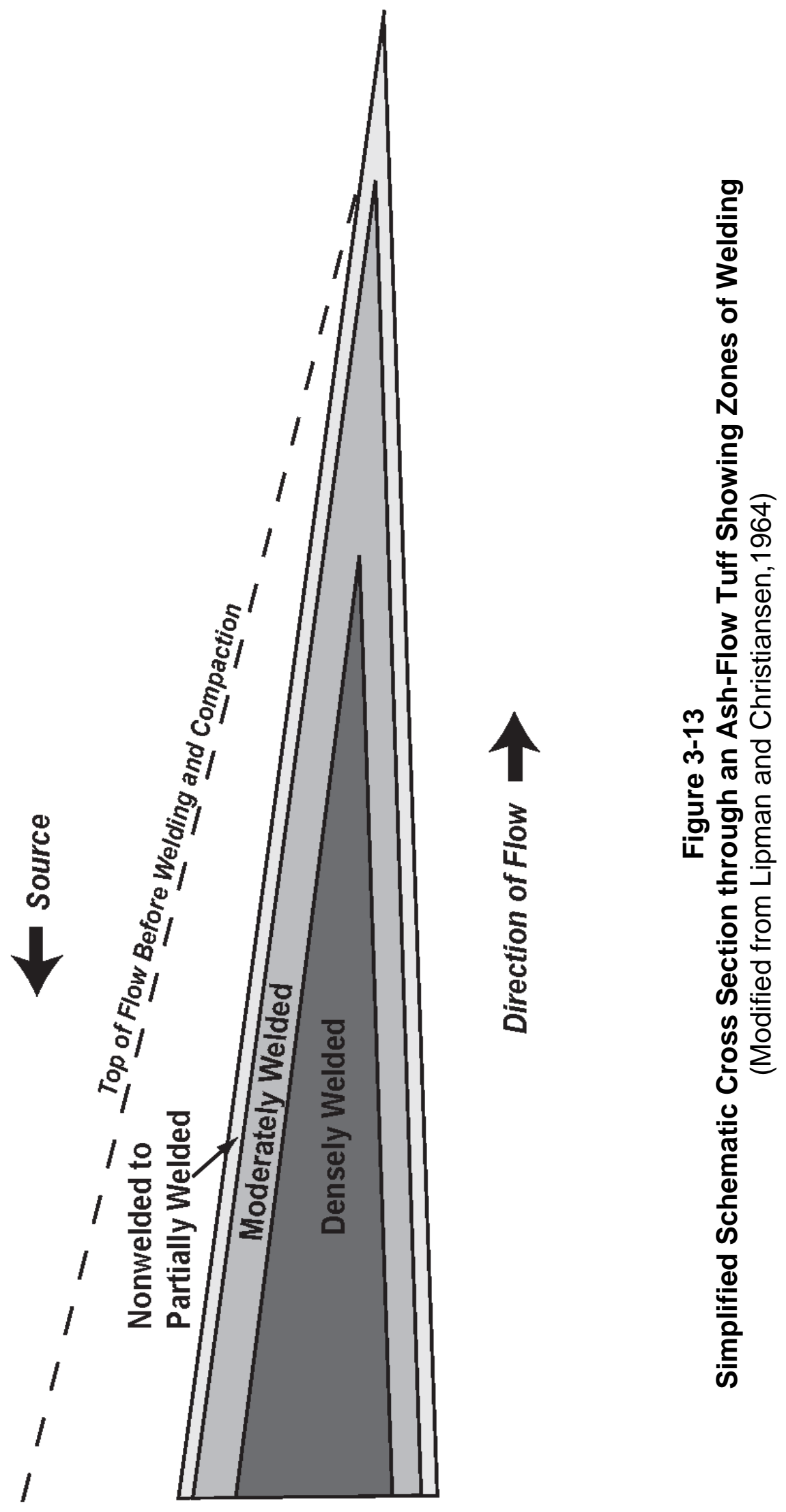
center of the flow. Thus, an ash-flow tuff deposit can include a welded lithofacies that forms a WTA in the interior portions of the flow unit that is surrounded by a nonwelded to poorly welded lithofacies that forms either a VTA or, if zeolitized, a TCU.

A specific example of how an ash-flow tuff and associated lithofacies are modeled in UGTA CAU-scale HFMs is provided by the Rainier Mesa Tuff, which occurs as a typical ash-flow tuff deposit in many areas of the NTS (Byers et al., 1976) (Figure 3-14). Surface exposures and drill

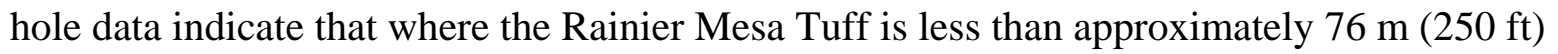
thick, typically near the distal edges of the deposit, the ash-flow deposit is poorly welded and commonly vitric. In these areas, all of the Rainier Mesa Tuff is categorized as a VTA and included as part of the Timber Mountain lower vitric-tuff aquifer (TM-LVTA) HSU (Figure 3-15). In locations where the Rainier Mesa Tuff is more than $76 \mathrm{~m}$ (250 ft) thick, typically closer to its source, all but the bottom $30 \mathrm{~m}(100 \mathrm{ft})$ is classified as the Timber Mountain welded-tuff aquifer (TM-WTA), and the bottom $30 \mathrm{~m}$ (100 ft) of nonwelded ash-flow tuff is generally included in the TM-LVTA. Note that in some places the TM-WTA may contain up to 20 percent VTA to accommodate the nonwelded top of the Rainier Mesa Tuff, which typically is thin and not easily mapped for a CAU-scale model.

Because of the relatively consistent nature of the welding process, the distribution of lithofacies related to the degree of welding in ash-flow tuffs is relatively easy to predict. The distribution of lithofacies in other lithologic units, however, can be more complex and difficult to predict, even in areas of good data control. An example is rhyolitic lava flows that can have complex distributions of lithofacies (Prothro and Drellack, 1997). Similar to ash-flow tuff deposits, individual rhyolite lava flows typically have a dense interior that forms a fractured aquifer, in this case an LFA. The outer portions of individual flows can be quite complex, however, consisting of various mixtures of vitric, devitrified, and zeolitic flow breccia and pumiceous and perlitic lava. Depending on their lithology and degree of alteration, these outer lithofacies may form VTAs, TCUs, or LFAs. Where confidently identified, mostly in Pahute Mesa drill holes, rhyolite lava lithofacies are categorized hydrogeologically and included in the appropriate HSUs.

\subsubsection{Lateral Stratigraphic Terminations}

Many rock units terminate laterally within the HFMs. These lateral terminations can be gradual or abrupt. An example of gradual thinning and the eventual pinching out of a unit is probably best observed in ash-flow tuffs where the welded portions of ash-flow tuffs (i.e., WTA) typically thin and pinch out toward the distal ends of the deposit (Figure 3-16). 


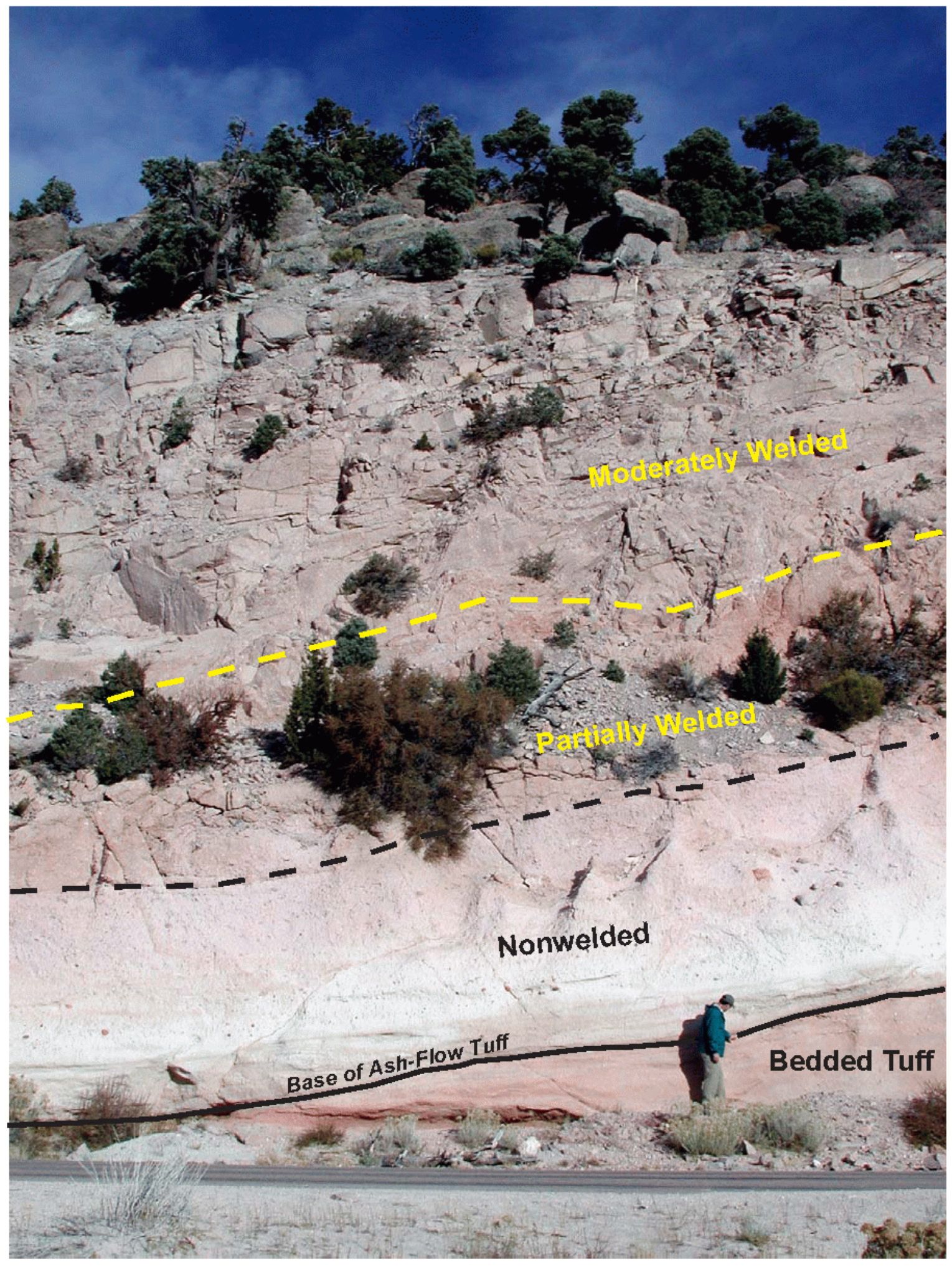

Figure 3-14

Exposure of Ash-Flow Tuff Lithofacies in the Basal Portion of the Rainier Mesa Tuff, Pahute Mesa, Area 19 


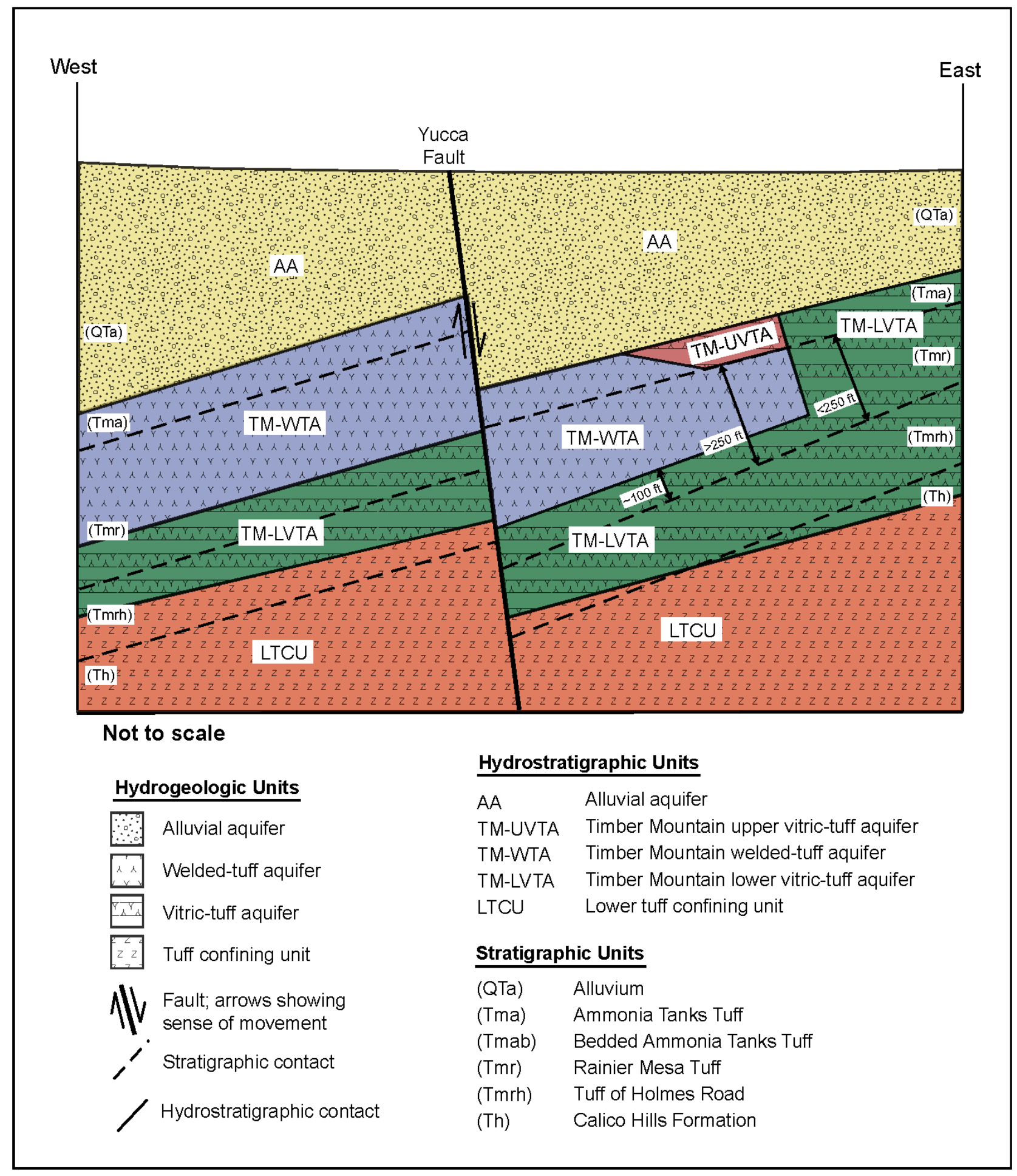

Figure 3-15

Schematic West-East Cross Section across Yucca Flat Illustrating the Delineation of HSUs with Respect to Lithofacies within the Rainier Mesa Tuff

(From BN, 2006) 


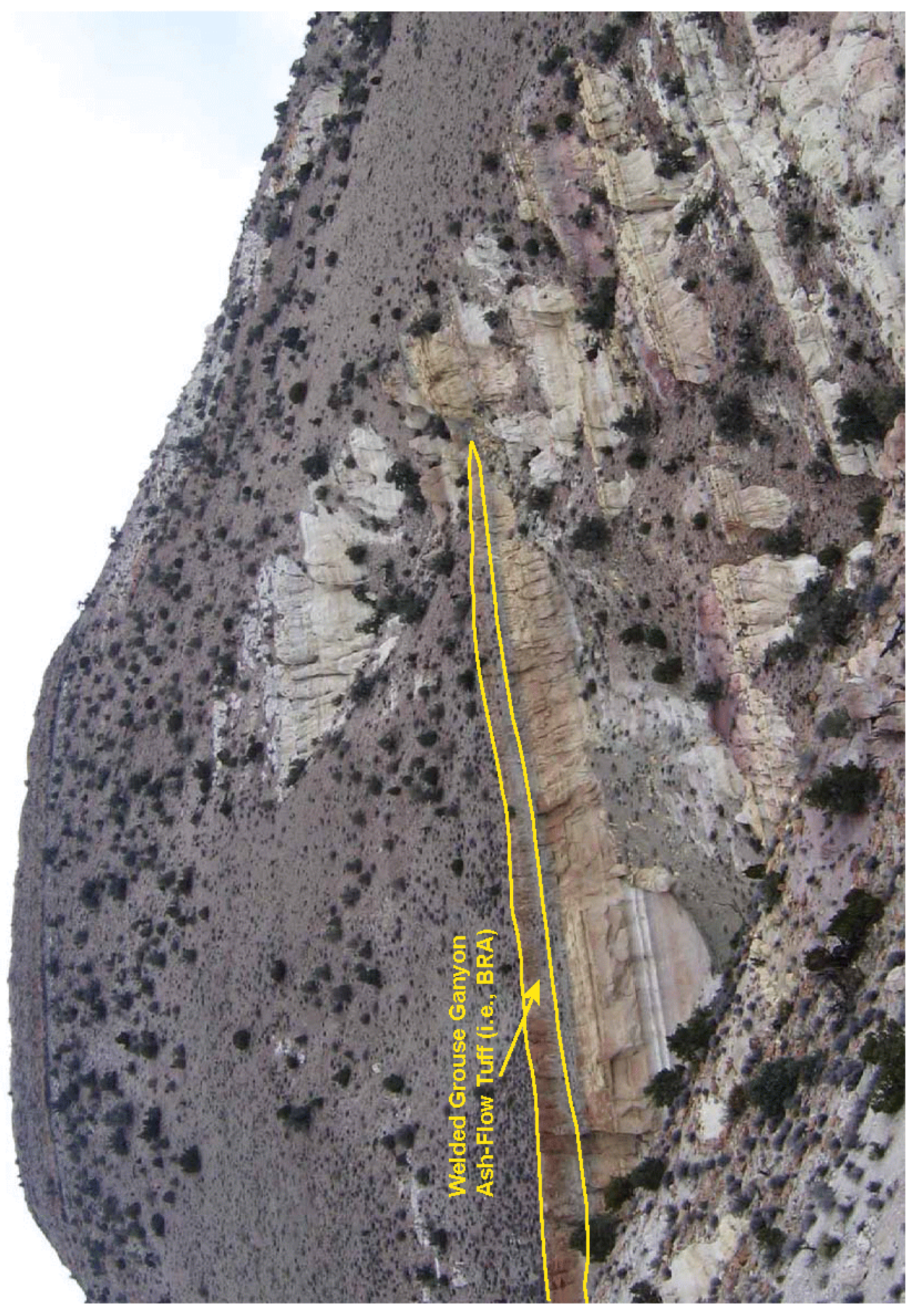

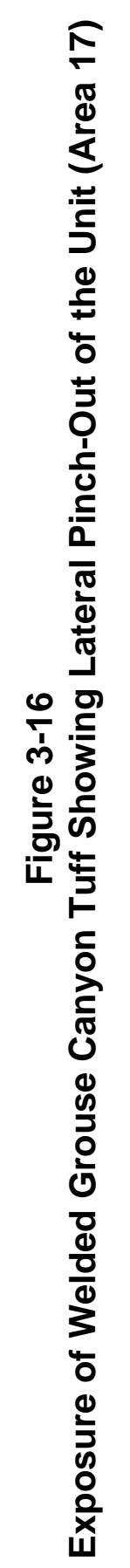


Abrupt lateral stratigraphic terminations are best illustrated by rhyolitic lava flows (i.e., LFAs). These extrusive igneous rocks flow out of vents and onto the ground surface; they typically form bulbous deposits with rather abrupt lateral terminations due to their high viscosity (Cas and Wright, 1987). Subsequent volcanic or alluvial activity may bury the lava-flow deposits, creating an embedded unit that terminates laterally in an abrupt fashion.

In addition to the obvious challenge of determining the locations of buried lateral terminations in areas of sparse data control, requirements of EarthVision ${ }^{\circledR}$, the software used to construct the HFMs, presents additional challenges to modeling hydrostratigraphic relationships related to lateral terminations. Many HSUs, particularly those composed of WTA, terminate and are effectively embedded within intervals of rock having consistent HGU character, most often TCU. Outside the lateral limits of an embedded HSU, the enclosing rocks are typically grouped within the same HSU because they are hydrologically similar and consist of the same HGU. However, where the embedded HSU is present, EarthVision ${ }^{\circledR}$ requires that the overlying unit be designated a separate HSU from the rocks beneath the embedded HSU even though they may consist of the same HGU, and are included within the same HSU beyond the lateral limits of the embedded HSU. As a consequence, the lateral limits of the overlying HSU are the same as that of the embedded HSU.

Figure 3-17 schematically illustrates a simple case involving the lateral termination of the Topopah Spring aquifer (TSA) in southern Yucca Flat. East of the limits of the TSA, all the units between the TM-LVTA and the Oak Spring Butte confining unit (OSBCU) consist of zeolitic tuff (i.e., TCU) and are grouped within the LTCU HSU. Where the TSA is present, however, the zeolitic rocks above the TSA are designated the UTCU, and the zeolitic rocks below the TSA retain the name LTCU. Where multiple laterally terminating HSUs occur, such as the northern portion of the RM-SM HFM area, the hydrostratigraphic relationships can become quite complex (Figure 3-18).

\subsubsection{Post-Depositional Alteration}

Post-depositional alteration, especially zeolitization, exerts a major influence on the hydrologic properties of rocks in the NTS region, and its presence or absence is one of the defining characteristics of HGUs (Winograd and Thordarson, 1975; Laczniak et al., 1996). Within much of the NTS region, an upper level of pervasive zeolitization can be identified at depth within volcanic rocks (Drellack and Thompson, 1990). The vitric (i.e., glassy) constituents of all nonwelded tuff and similar low density volcanic rocks below this depth are typically altered. Alteration products include mainly zeolite in the upper levels, with quartzo-feldspathic mineral 

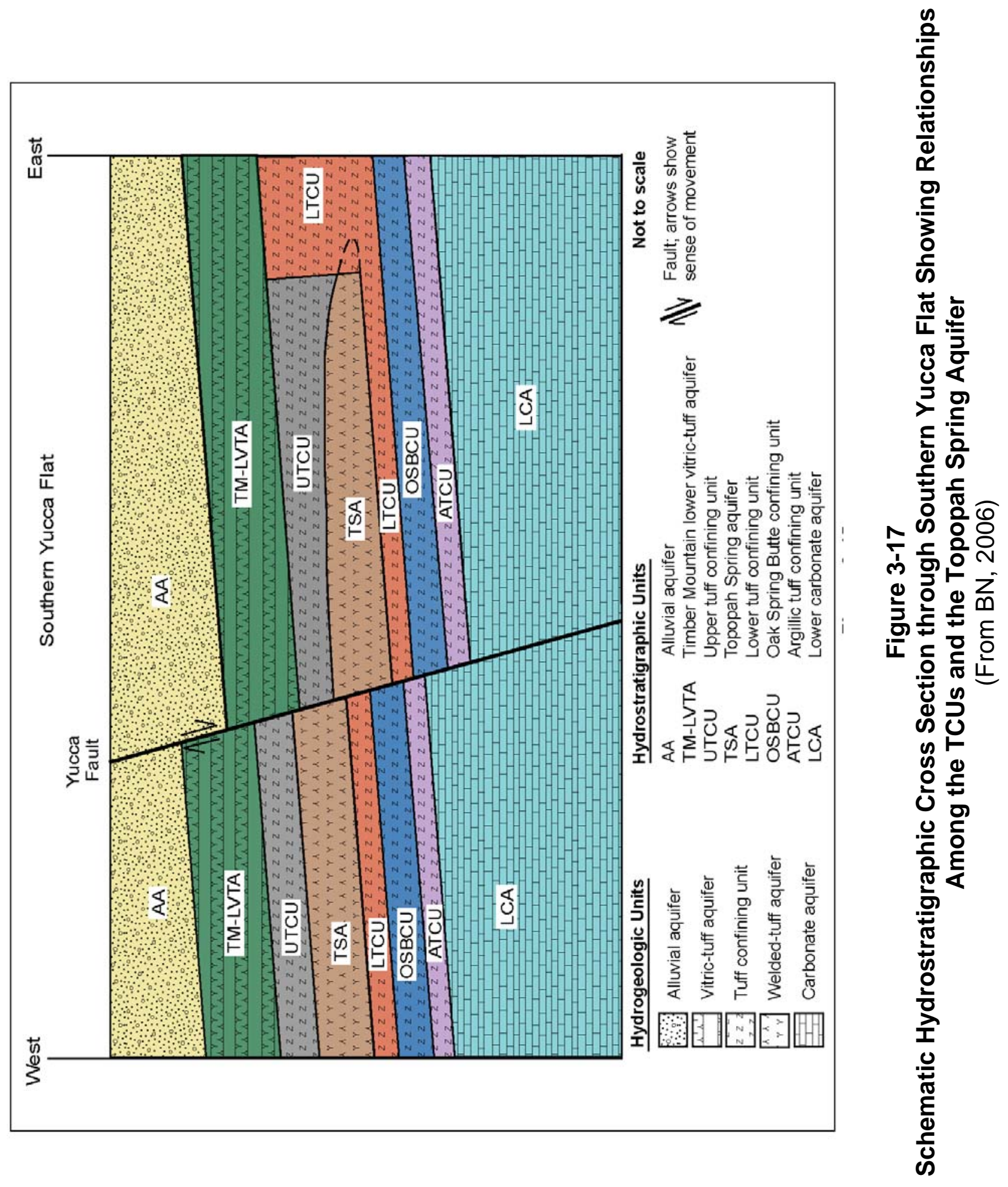

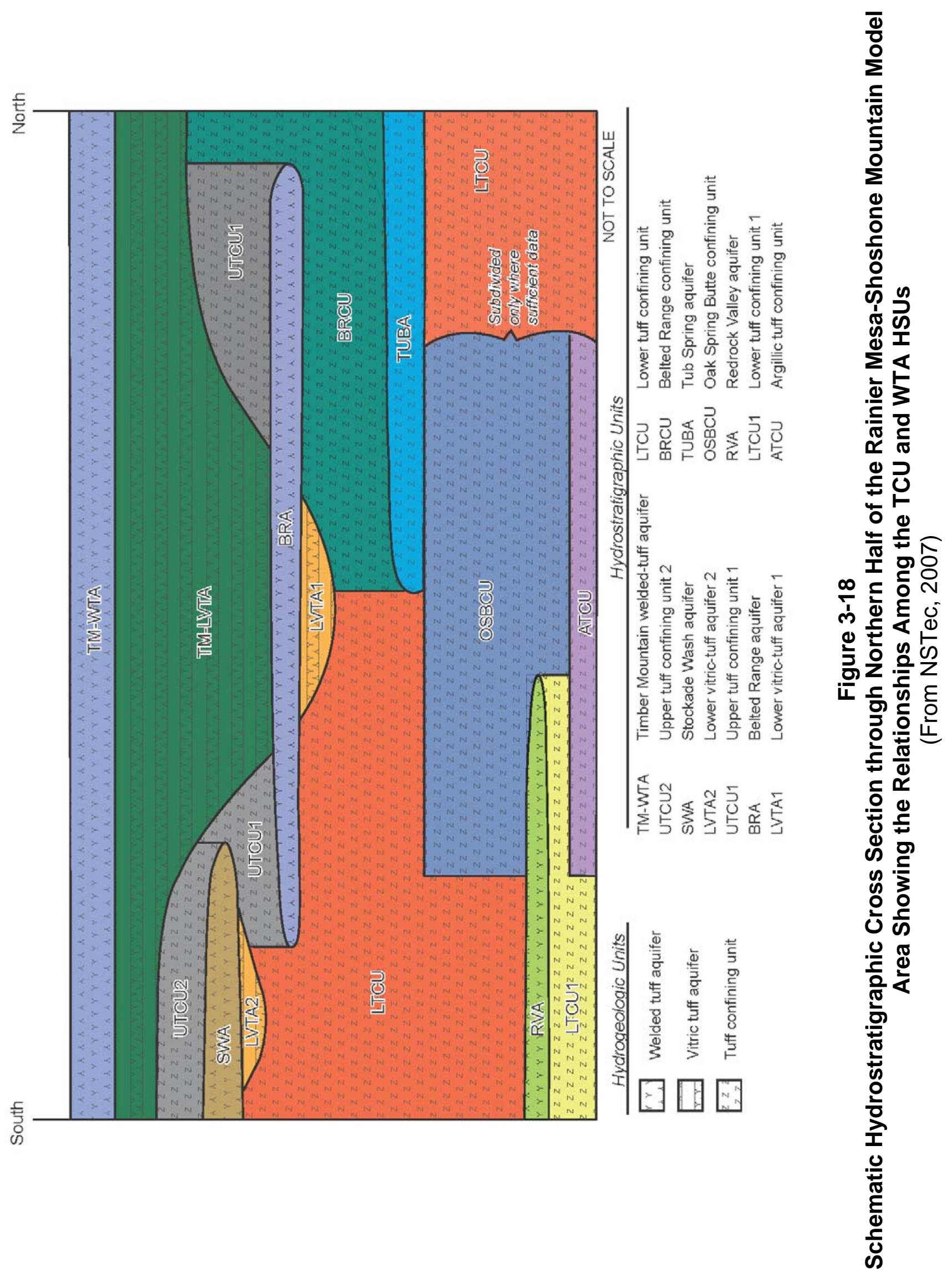
assemblages becoming more dominant lower, and clay dominating near the base of the volcanic sequence (Prothro, 2005). In all the UGTA CAU-scale HFMs, the top of pervasive zeolitization always defines the top of a TCU HSU. Because zeolitization is strongly influenced by lithology and the position of the water table (Hoover, 1968), the top of zeolitization is usually independent of stratigraphy, and commonly cuts across stratigraphic boundaries (Figure 3-19). Therefore, the tops of many confining unit HSUs cannot be defined by stratigraphic boundaries.

\subsubsection{Thrust Plates}

Mesozoic thrust faulting associated with both the east-directed Belted Range system and the slightly younger, west-directed CP thrust fault results in hydrostratigraphic complexities within the upper portion of the pre-Tertiary section at the NTS (Cole and Cashman, 1999). As a result of this thrusting, thrust plates of older stratigraphic units have been transported up from depth along thrust faults and emplaced over younger units (Figure 3-20). Where these thrust plates are separated from correlative rocks by underlying younger rocks of different hydrologic character, the thrusted rocks are delineated as a separate HSU to distinguish them from lower correlative and unthrusted rocks.

The Belted Range thrust system is particularly complex. This thrust system has brought Precambrian and late Cambrian siliciclastic rocks of the lower clastic confining unit (LCCU) up and over Paleozoic carbonate rocks of the LCA, which themselves have been emplaced over younger siliciclastic rocks of the UCCU by imbricate thrust faulting that occurred structurally below and generally in front of the Belted Range thrust fault (Cole and Cashman, 1999) (Figure 3-21). Thrusted Precambrian and late Cambrian siliciclastic rocks of the LCCU are designated as LCCU1 to distinguish them from the deeper and unthrusted LCCU. Similarly, the thrusted carbonate rocks are designated LCA3 to distinguish them from the deeper and unthrusted LCA.

The LCA3 designation is also used to distinguish Paleozoic carbonate rocks of the LCA that have been thrust westward over the UCCU along the CP thrust fault beneath the western portion of Yucca Flat. As a result, LCA3 occurs as two separate thrust plates associated with two different thrust faults, but are designated the same HSU because they both consist of Paleozoic carbonate rocks and have similar structural relationships (i.e., thrusted over UCCU).

Precambrian and late Cambrian siliciclastic rocks of the LCCU are interpreted to have been emplaced over LCA rocks along the CP thrust fault at depth beneath Yucca Flat (BN, 2006). These thrusted LCCU rocks are designated LCCU2 to distinguish them from deeper unthrusted 

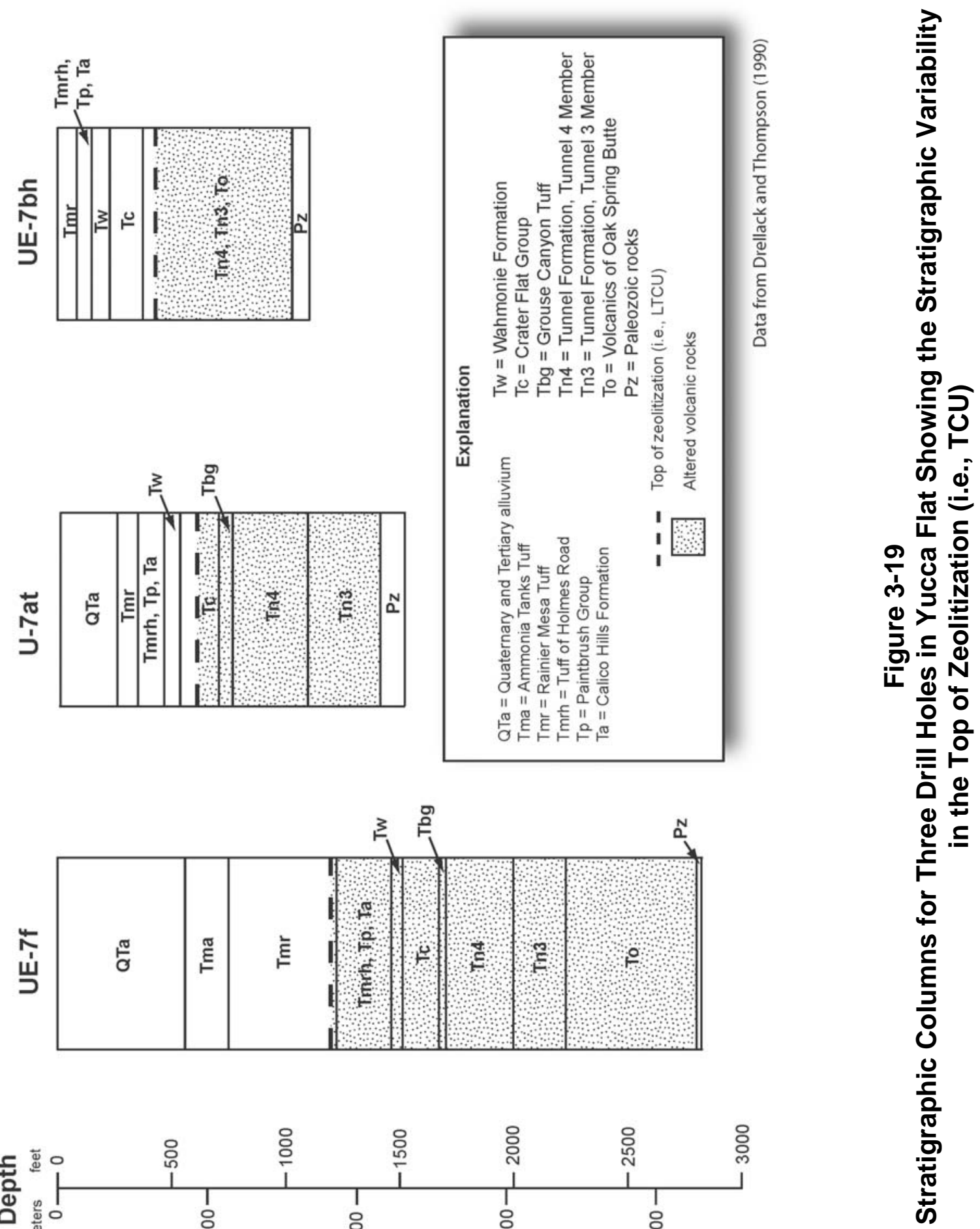


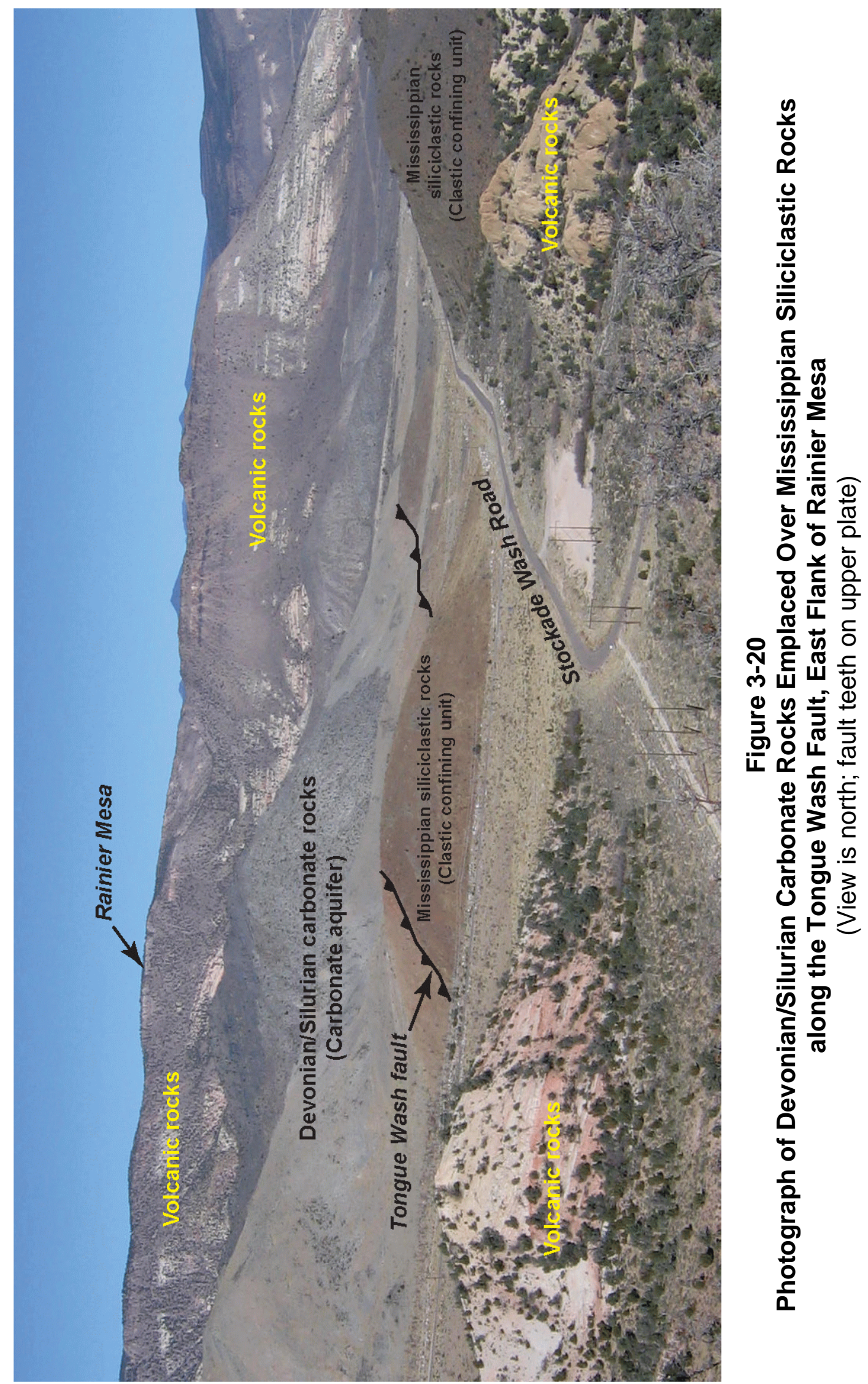




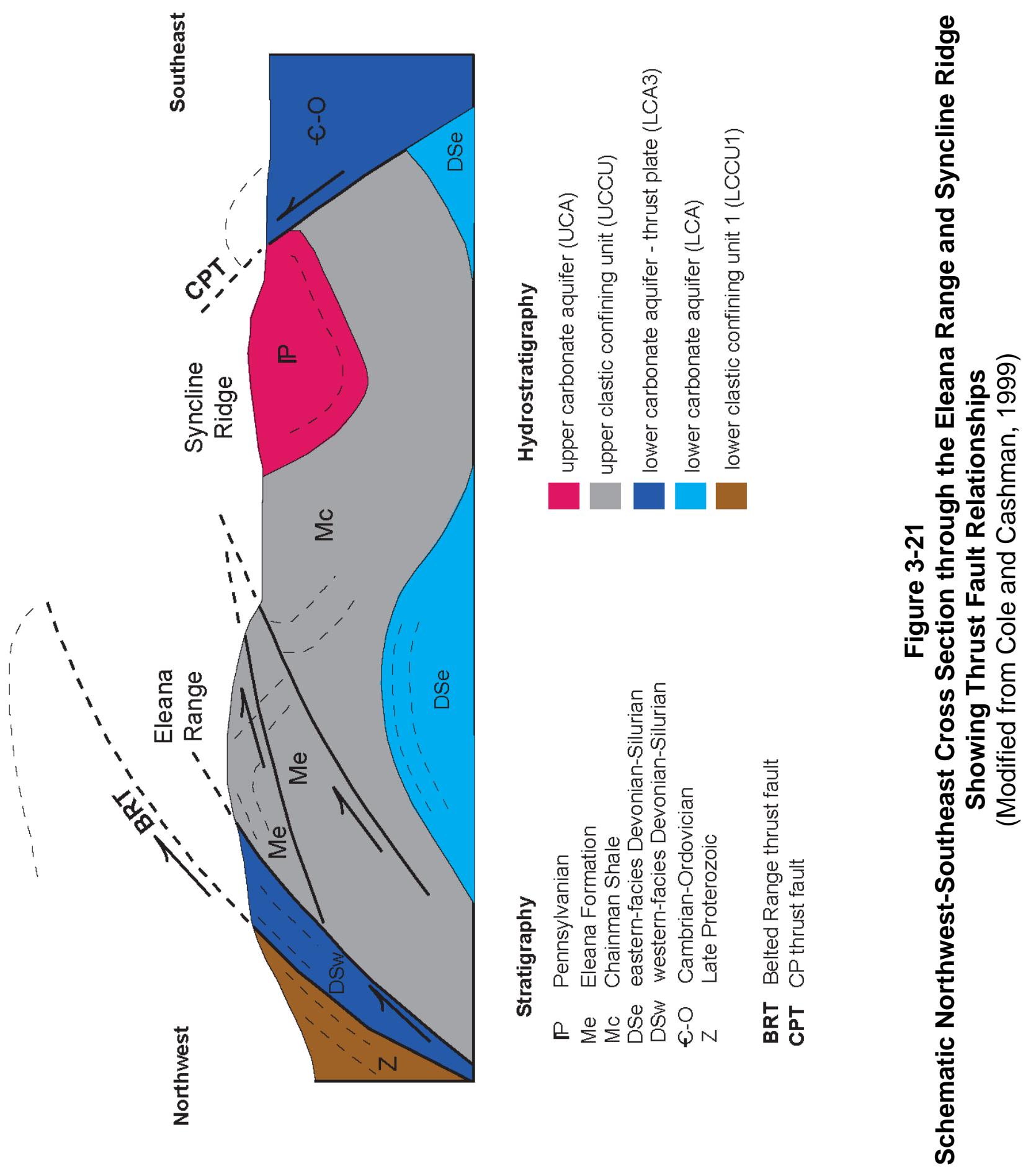


LCCU. Complex imbricate thrust faulting related to the Belted Range thrust fault and observed in UGTA Well ER-12-1 necessitated the delineation of a UCCU1 HSU and another LCA3 HSU designated LCA3-1.

\subsubsection{Composite Units}

The CM designation was originally developed as part of the PM-OV HFM to address the uncertainty associated with complex volcanic intervals composed of poorly understood distributions of differing HGUs (BN, 2002). The most common CM HSU consists of a stratigraphic interval containing multiple LFA HGUs intercalated within TCU or VTA. Because subsurface control is insufficient to confidently correlate and map the lateral extent of individual LFAs, they are grouped together with the associated TCU HGUs into a single HSU. The upper and lower boundaries of CM HSUs typically correspond to stratigraphic boundaries. For example, the Calico Hills zeolitic composite unit (CHZCM) consists of several individual rhyolite lava flows (i.e., LFAs), assigned stratigraphically to the Calico Hills Formation, that are intercalated within zeolitic tuff (i.e., TCUs) also assigned to the Calico Hills Formation (DOE/NV, 1998). Consequently, the top and bottom of the CHZCM correspond to the stratigraphic top and bottom of the Calico Hills Formation. Some CM HSUs, such as the Fortymile Canyon composite unit, may also contain WTA along with LFA and TCU. The composite unit was assigned an abbreviation of CM to avoid confusion with the more common confining unit HGU, which is abbreviated CU.

A unique CM HSU is the Timber Mountain composite unit (TMCM). The CM designation was applied to the TMCM to address uncertainties associated with the occurrence and distribution of open fractures within a very thick sequence of predominantly welded ash-flow tuffs (i.e., WTAs) that accumulated within the Timber Mountain caldera complex (BN, 2002). The intra-caldera setting, surface exposures, and information from deep drill holes suggest that fracture permeability within the TMCM may be significantly reduced in places by secondary mineralization and poorly developed cooling and tectonic fractures. Consequently, groundwater-flow properties of the TMCM may be considerably different than those for WTA-dominated HSUs in areas outside of the Timber mountain caldera complex (e.g., Timber Mountain aquifer, Tiva Canyon aquifer, and Topopah Spring aquifer).

\subsubsection{Uncertainty}

As can be inferred from above discussions of the hydrogeologic complexities of the NTS region, geologic interpretations, such as those associated with HSU delineation and modeling, contain varying amounts of uncertainty, some of which can be quite large. This geologic complexity is offset somewhat by the shear amount of geologic study that has occurred in the NTS region 
during the past 50 years. This has resulted in a very good understanding of the basic geologic setting of the NTS region. The geologic data generated by scientists from the federal government, national laboratories, federal contractors, and academia is of high quality. In weapon testing areas, such as Yucca Flat and Pahute Mesa, the quantity of geologic data, particularly subsurface data, is probably greater than in other areas in the Great Basin. However, the geologic complexity of the NTS region means that geologic uncertainty increases both laterally and vertically away from the subsurface control, and this uncertainty can increase very rapidly in many places. In most areas of the NTS region, uncertainty increases with increasing depth to a point in every HFM where the geology, including HSUs, are highly conceptualized.

With regard to the UGTA CAU-scale hydrostratigraphic system, the least uncertainty is probably associated with HGU designations in outcrop and drill holes. Assigning HGU designations to rocks exposed at the surface and encountered in drill holes is a relatively straightforward process, and is typically done with a relatively high degree of confidence. HGU classification of rock units is based on basic lithologic information (e.g., carbonate versus shale, nonwelded tuff versus welded tuff, vitric tuff versus zeolitic tuff) which usually can be accurately determined macroscopically from field hand samples and drill cuttings.

Uncertainty increases somewhat when assigning HGUs to specific HSUs because determining stratigraphic information, which is essential for proper HSU delineation, is typically more difficult than determining lithologic information. However, detailed stratigraphic studies conducted at the NTS have resulted in a large and robust data set and knowledge base for the stratigraphic units in the NTS area. HSU contacts in drill holes can usually be determined with relative precision, sometimes within $0.3 \mathrm{~m}$ (1 ft), using mainly drill cuttings and geophysical logs.

The uncertainty associated with modeling HSU volumes increases with increasing distance, both horizontally and vertically, from data control such as outcrop and drill holes. Typically, buried HSUs in areas of sparse drill hole control are only conceptualized, and thus have relatively high degrees of uncertainty regarding their precise extent, thickness, and depth below the surface (for example, the intra-caldera intrusive confining units). The least uncertain of these characteristics is probably extent. General knowledge of the geologic setting will typically allow for a reasonable approximation of the presence of an HSU in a particular area. Thickness of an HSU in areas of sparse control can usually be approximated from the geologic setting and stratigraphic and lithologic composition of the HSU. However, faulting contemporaneous with volcanic activity (e.g., calderas) and alluvial deposition (e.g., Yucca Flat) can result in dramatic thickness differences across short distances. If fault location and amount of displacement are 
poorly constrained, then the thicknesses of some HSUs may be highly uncertain. Because of the intense faulting in the NTS region from both tectonic and volcanic processes (i.e., caldera development), depths to buried HSUs in areas of poor control can have uncertainties on the order of hundreds of meters.

For more detailed information on the uncertainty associated with each HSU, the reader is referred to the full descriptions of the HSUs presented in the HFM reports (BN, 2002; 2005; 2006; NSTec, 2007). However, it is very difficult to quantify and fully explain geologic uncertainty associated with HSU delineation and modeling in such a complex geologic setting as the NTS region. Geologic uncertainty associated with HSUs is better addressed and incorporated into flow and transport models, as well as HFMs, by a close synergistic relationship between geologists and flow and transport modelers during all phases of model construction and evaluation. 


\subsection{SUMMARY}

Four 3-D CAU-scale HFMs have been constructed for the UGTA Sub-Project to support groundwater flow and contaminant transport modeling. All four overlapping models were constructed using the same hydrostratigraphic system, which required careful evaluation of the complex stratigraphy of the NTS region and incorporation of the lithologic variations that affect rock hydrologic properties. The HSUs of each CAU-scale model area are described in the documentation package for each, but this document provides a comprehensive overview of the NTS-wide, CAU-scale hydrostratigraphic system, and may serve as a general reference resource for the HSUs used in all the UGTA HFMs.

The construction of HFMs required the development of a hydrostratigraphic system that consistently defines the lateral and vertical distributions of rock units according to their waterbearing qualities and in such a way that they can be accurately depicted in three dimensions within the HFMs. To achieve this requirement within the very complex geologic setting of the NTS, the UGTA CAU-scale hydrostratigraphic system uses a two-level classification scheme in which HGUs are organized into HSUs that form the unit volumes, or layers, within the HFMs.

The UGTA hydrostratigraphic units were defined using principles described by Maxey (1964) and Seaber (1988), and incorporating the very large database of geologic and hydrogeologic data available for the NTS primarily in the form of surface geologic maps and lithologic, geophysical, and hydrologic data from thousands of boreholes. The NTS regional volcanic stratigraphy of Warren et al. (2003) defines more than 300 stratigraphic units, and more than 20 pre-Tertiary stratigraphic units have been mapped (Slate et al., 1999). The basic hydrogeologic framework for the NTS established by Winograd and Thordarson (1975) and updated by Laczniak et al. (1996) delineated many of the aquifers and aquitards within the NTS region, which were the basis for the ten HGUs used as the basis for the HSUs.

The process used to define the current 76 UGTA HSUs is described, including how various types of geologic complexity (facies changes, lateral stratigraphic terminations, alteration, etc.) were addressed. Several examples with graphic depictions are provided to illustrate the "rules" used to define the HSUs of the UGTA framework for the NTS region. All 76 HSUs are listed in this report, including their presence or absence within each of the four CAU-scale HFMs. 
This page intentionally left blank. 


\subsection{REFERENCES}

App, F. N., 1983. “Progress in Seismic Exploration at Los Alamos.” In: Hudson, B. C., E. M. Jones, C. E. Keller, and C. W. Smith, eds., Proceedings of the Monterey Containment Symposium, Monterey, California, August 26-28, 1981. Los Alamos National Laboratory Report LA-9211-C, vol. 1, pp. 343-353. Los Alamos, NM.

Asch, T. H., B. D. Rodriguez, J. A. Sampson, E. L. Wallin, and J. M. Williams, 2006. Deep Resistivity Structure of Yucca Flat, Nevada Test Site, Nevada. U.S. Geological Survey OpenFile Report OFR-06-1261, 86 pp. Denver, CO.

Barnes, H., F. N. Houser, and F. G. Poole, 1963. “Geologic Map of the Oak Spring Quadrangle, Nye County, Nevada.” U.S. Geological Survey Map GQ-214, scale 1:24,000.

Washington, DC.

Barnes, H., R. L. Christiansen, and F. M. Byers, Jr., 1965. “Geologic Map of the Jangle Ridge Quadrangle, Nye and Lincoln Counties, Nevada.” U.S. Geological Survey Map GQ-363, scale 1:24,000. Washington, DC.

Barnes, H., E. B. Ekren, C. L. Rodgers, and D. C. Hedlund, 1982. "Geology and Tectonic Maps of the Mercury Quadrangle, Nye and Clark Counties, Nevada.” U.S. Geological Survey, Miscellaneous Geologic Investigations Series Map I-1197, scale 1:24,000.

Bath, G. D., C. E. Jahren, J. G. Rosenbaum, and M. J. Baldwin, 1983. "Magnetic Investigations.” In: Geologic and Geophysical Investigations of Climax Stock Intrusive, Nevada. U.S. Geological Survey Open-File Report 83-377, pp. 40-57. Denver, CO.

Bechtel Nevada, 2002. A Hydrostratigraphic Model and Alternatives for the Groundwater Flow and Contaminant Transport Model of Corrective Action Units 101 and 102: Central and Western Pahute Mesa, Nye County, Nevada. DOE/NV/11718--706. Las Vegas, NV.

Bechtel Nevada, 2005. A Hydrostratigraphic Model and Alternatives for the Groundwater Flow and Contaminant Transport Model of Corrective Action Unit 98: Frenchman Flat, Clark, Lincoln, and Nye County, Nevada. DOE/NV/11718--1064. Las Vegas, NV.

Bechtel Nevada, 2006. A Hydrostratigraphic Model and Alternatives for the Groundwater Flow and Contaminant Transport Model of Corrective Action Unit 97: Yucca Flat-Climax Mine, Lincoln and Nye Counties, Nevada. DOE/NV/11718--1119. Las Vegas, NV.

Belcher, W. R., ed., 2004. Death Valley Regional Ground-Water Flow System, Nevada and California-Hydrogeologic Framework and Transient Ground-Water Flow Model. U.S. Geological Survey Scientific Investigations Report 2004-5205, 408 pp.

Blankennagel, R. K., and J. E. Weir, Jr., 1973. Geohydrology of the Eastern Part of Pahute Mesa, Nevada Test Site, Nye County, Nevada. U.S. Geological Survey Professional Paper 712-B, 35 pp. Washington, DC. 
BN, see Bechtel Nevada.

Burkhard, N. R., 1983. "NTS Seismic Reflection Data and the Problems Thereof.” In:

Hudson, B. C., E. M. Jones, C. E. Keller, and C. W. Smith, eds., Proceedings of the Monterey Containment Symposium, Monterey, California, August 26-28, 1981. Los Alamos National Laboratory Report LA-9211-C, vol. 1, pp. 339-341. Los Alamos, NM.

Byers, F. M., Jr., and H. Barnes, 1967. “Geologic Map of the Paiute Ridge Quadrangle, Nye and Lincoln Counties, Nevada.” U.S. Geological Survey Geologic Quadrangle Map GQ-577, scale 1:24,000. Washington, DC.

Byers, F. M., Jr. and D. Cummings, 1967. “Geologic Map of the Scrugham Peak Quadrangle, Nye County, Nevada.” U.S. Geological Survey Geologic Quadrangle Map GQ-695, scale 1:24,000. Washington, DC.

Byers, F. M., Jr., C. L. Rogers, W. J. Carr, and S. J. Luft, 1966. “Geologic Map of the Buckboard Mesa Quadrangle, Nye County, Nevada.” U.S. Geological Survey Geologic Quadrangle Map GQ-552, scale 1:24,000. Washington, DC.

Byers, F. M., Jr., W. J. Carr, P. P. Orkild, W. D. Quinlivan, and K. A. Sargent, 1976. Volcanic Suites and Related Cauldrons of the Timber Mountain-Oasis Valley Caldera Complex, Southern Nevada. U.S. Geological Survey Professional Paper 919, 70 pp. Washington, DC.

Carr, W. J., and W. D. Quinlivan, 1966. “Geologic Map of the Timber Mountain Quadrangle, Nye County, Nevada.” U.S. Geological Survey Geologic Quadrangle Map GQ-503, scale 1:24,000. Washington, DC.

Carroll, R. D., 1983. “Seismic Velocity and Postshot Properties in and Near Chimneys.” In: Hudson, B. C., E. M. Jones, C. E. Keller, and C. W. Smith, eds., Proceedings of the Monterey Containment Symposium, Monterey, California, August 26-28, 1981. Los Alamos National Laboratory Report LA-9211-C, vol. 1, pp. 379-396. Los Alamos, NM.

Carroll, R. D., 1986. Shear-Wave Velocity Measurements in Volcanic Tuff in Rainier Mesa Tunnels, Nevada Test Site, Nevada. U.S. Geological Survey Report 474-321, 24 pp.

Carroll, R. D., 1990. Electric Logging and Electrical Properties of Rocks in Rainier Mesa Area, Nevada Test Site, Nevada. U.S. Geological Survey Open-File Report 90-31, 90 pp.

Carroll, R. D., 1994. Measurement of Seismic P-and S-Wave Attenuation in Volcanic Tuff, Rainier Mesa Tunnels, Nevada Test Site. U.S. Geological Survey Open-File Report 94-618, $55 \mathrm{pp}$.

Carroll, R. D., and J. E. Kibler, 1983. Sourcebook of Locations of Geophysical Surveys in Tunnels and Horizontal Holes Including Results of Seismic Refraction Surveys, Rainier Mesa, Aqueduct Mesa, and Area 16, Nevada Test Site. U.S. Geological Survey Open-File Report 83-399, 85 pp. 
Cas, R. A. F., and J. V. Wright, 1987. Volcanic Successions. Allen and Unwin, London. pp. 79-87.

Christiansen, R. L., and D. C. Noble, 1968. “Geologic Map of the Trail Ridge Quadrangle, Nye County, Nevada.” U.S. Geological Survey Geologic Quadrangle Map GQ-774, scale 1:24,000. Washington, DC.

Christiansen, R. L., and P. W. Lipman, 1965. "Geologic Map of the Topopah Spring Northwest Quadrangle, Nye County, Nevada.” U.S. Geological Survey Geologic Quadrangle Map GQ-444, scale 1:24,000. Washington, DC.

Cole, J. C., 1997. Major Structural Controls on the Distribution of Pre-Tertiary Rocks, Nevada Test Site Vicinity, Southern Nevada. U.S. Geological Survey Open-File Report 97-533, scale 1:100,000, 19 pp. Denver, CO.

Colton, R. B., and E. J. McKay, 1966. “Geologic Map of the Yucca Flat Quadrangle, Nye and Lincoln Counties, Nevada.” U.S. Geological Survey Geologic Quadrangle Map GQ-582, scale 1:24,000. Washington, DC.

Colton, R. B., and D. C. Noble, 1967. "Geologic Map of the Groom Mine SW Quadrangle, Nye and Lincoln Counties, Nevada.” U.S. Geological Survey Map GQ-719, scale 1:24,000. Washington, DC.

D’Agnese, F. A., C. C. Faunt, A. K. Turner, and M. C. Hill, 1997. Hydrogeologic Evaluation and Numerical Simulations of the Death Valley Regional Groundwater Flow System, Nevada and California. U.S. Geological Survey Professional Paper 1607. Denver, CO.

DOE/NV, see U.S. Department of Energy, Nevada Operations Office.

Drellack, S. L., Jr., and P. H. Thompson, 1990. Selected Stratigraphic Data for Drill Holes in LANL Use Areas of Yucca Flat, NTS. DOE/NV/10322--39. Fenix \& Scisson, Inc., Las Vegas, NV.

Ekren, E. B., and K. A. Sargent, 1965. "Geologic Map of the Skull Mountain Quadrangle, Nye County, Nevada.” U.S. Geological Survey Geologic Quadrangle Map GQ-387, scale 1:24,000. Washington, DC.

Ekren, E. B., R. E. Anderson, P. P. Orkild, and E. N. Hinrichs, 1966. “Geologic Map of the Silent Butte Quadrangle, Nye County, Nevada.” U.S. Geological Survey Geologic Quadrangle Map GQ-493, scale 1:24,000. Washington, DC.

Ferguson, J. F., A. H. Cogbill, and R. G. Warren, 1994. “A Geophysical-Geological Transect of the Silent Canyon Caldera Complex, Pahute Mesa, Nevada.” Journal of Geophysical Research, vol. 99, no. 33, pp. 4,323-4,339.

Fiero, B., 1986. Geology of the Great Basin. University of Nevada Press, Reno Nevada, 197 p. 
Frizzell, V. A., Jr., and J. Shulters, 1990. “Geologic Map of the Nevada Test Site, Southern Nevada,” U.S. Geological Survey Miscellaneous Investigation Series Map 1-2046, scale 1:100,000. Denver, CO.

Gibbons, A. B., E. N. Hinrichs, W. R. Hansen, and R.W. Lemke, 1963. "Geologic Map of the Rainier Mesa Quadrangle, Nye County, Nevada.” U.S. Geological Survey Map GQ-215, scale 1:24,000. Washington, DC.

Gillespie, D., J. D. Donithon, and P. R. Seaber, 1996. NTS Water-Supply Wells.

DOE/NV/10845-56 (DRI Publication No. 45138). Desert Research Institute, Las Vegas, NV.

Grauch, V. J. S., D. A. Sawyer, C. J. Fridrich, and M. R. Hudson, 1997. Geophysical Interpretations West of and Within the Northwestern Part of the Nevada Test Site. U.S. Geological Survey Open-File Report 97-476. Denver, CO.

Hansen, D. J., P. D. Greger, C. A. Wills, and W. K. Ostler, 1997. Nevada Test Site Wetlands Assessment. DOE/NV/11718--124. Prepared for the U.S. Department of Energy by Bechtel Nevada, Las Vegas, NV.

Harrill, J. R., J. S. Gates, and J. M. Thomas, 1988. Major Groundwater Flow Systems in the Great Basin Region of Nevada, Utah and Adjacent States. Hydrological Investigation Atlas HA-694-C, scale 1:1,000,000. U.S. Geological Survey, Denver, CO.

Healey, D. L., 1968. “Application of Gravity Data to Geologic Problems at Nevada Test Site.” In: Eckel, E. B., ed., Nevada Test Site. Memoir 110, pp. 147-156. The Geological Society of America, Inc. Boulder, CO.

Healey, D. L., R. N. Harris, D. A. Ponce, and H. W. Oliver, 1987. Complete Bouguer Gravity Map of the Nevada Test Site and Vicinity, Nevada. U.S. Geological Survey Open-File Report 87-506. Denver, CO.

Hearst, J. R., and N. R. Burkhard, 1989. “A Study of the Difference Between Gravimetric and Gamma-Gamma Density Near the Surface in Northern Yucca Flat.” In: Olsen, C., and S. Warner, eds., The Fifth Symposium on the Containment of Underground Nuclear Explosions, Lawrence Livermore National Laboratory. CONF-8909163, vol. 2, p. 310.

Hinrichs, E. N., 1968. “Geologic Map of the Camp Desert Rock Quadrangle Nye County, Nevada.” U.S. Geological Survey Quadrangle Map G-726, scale 1:24,000. Washington, DC.

Hinrichs, E. N. and E. J. McKay, 1965. “Geologic Map of the Plutonium Valley Quadrangle, Nye and Lincoln Counties, Nevada.” U.S. Geological Survey Geologic Quadrangle Map GQ-384, scale 1:24,000. Washington, DC.

Hinrichs, E. N., R. D. Krushensky, and S. J. Luft, 1967. “Geologic Map of the Ammonia Tanks Quadrangle, Nye County, Nevada.” U.S. Geological Survey Geologic Quadrangle Map GQ-638, scale 1:24,000. Washington, DC. 
Hoover, D. L., 1968. “Genesis of Zeolites, Nevada Test Site.” In: Eckel, E. B., ed., Nevada Test Site. Geological Society of America, Inc., Memoir 110, pp. 275-284. Boulder, CO.

Houser, F. N., R. E. Davis, and W. L. Emerick, 1961. Geologic Reconnaissance of Granitic Intrusive Masses at Gold Meadows, Tem Piute, and Trappman's Camp, Lincoln and Nye Counties, Nevada, and Comparison with the Climax Stock at the Nevada Test Site.

U.S. Geological Survey Trace Elements Investigations Report TEI-793, 20 pp. Washington, DC.

IT, see IT Corporation.

IT Corporation, 1996a. Regional Geologic Model Data Documentation Package (Phase I, Data Analysis Documentation, Volume I, Parts 1 and 2). ITLV/10972--181. Las Vegas, NV.

IT Corporation, 1996b. Potentiometric Data Task Documentation Package (Phase I, Data Analysis Documentation, Volume II). ITLV/10972--181. Las Vegas, NV.

IT Corporation, 1996c. Hydrologic Parameters Data Documentation Package (Phase I, Data Analysis Documentation, Volume IV). ITLV/10972--181. Las Vegas, NV.

IT Corporation, 1996d. Groundwater Flow Model Documentation Package (Phase 1, Data Analysis Documentation, Volume VI). ITLV/10972--181. Las Vegas, NV.

Jachens, R. C., and B. C. Moring, 1990. Maps of Cenozoic Deposits and the Isostatic Residual Gravity Over Basement for Nevada. U.S. Geological Survey Open File Report 90-404, 15 pp.

Kirchoff-Stein, K. S., D. A. Ponce, and B. A. Chuchel, 1989. "Preliminary Aeromagnetic Map of the Nevada Test Site and Vicinity, Nevada.” U.S. Geological Survey Open-File Report 89-446. Denver, CO.

Kososki, B. A., S. L. Robbins, and J. S. Schomoker, 1978. Principle Facts for Borehole Gravity Stations in Test Well UE 19z, Exploratory Drill Hole PM-1, and Water Well 5a, Nevada Test Site, Nye County, Nevada. U.S. Geological Survey Open-File Report 78-983, 17 pp. Reston, VA.

Laczniak, R. J., J. C. Cole, D. A. Sawyer, and D. A. Trudeau, 1996. Summary of Hydrogeologic Controls on the Ground-water Flow at the Nevada Test Site, Nye County, Nevada. U.S. Geological Survey Water-Resources Investigation Report 96-4109. Carson City, NV.

Lipman, P. W., and R. L. Christiansen, 1964. Zonal Features of an Ash-Flow Sheet in the Piapi Canyon Formation, Southern Nevada. U. S. Geological Survey Professional Paper 501B, pp. B74-B78.

Lipman, P. W., and E. J. McKay, 1965. “Geologic Map of the Topopah Spring SW Quadrangle, Nye County, Nevada.” U.S. Geological Survey Geologic Quadrangle Map GQ-439, scale 1:24,000. Washington, DC. 
Lipman, P. W., W. D. Quinlivan, W. J. Carr, and R. E. Anderson, 1966. "Geologic Map of the Thirsty Canyon SE Quadrangle, Nye County, Nevada.” U.S. Geological Survey Geologic Quadrangle Map GQ-489, scale, 1:24,000. Washington, DC.

Maldonado, F., 1977. Summary of the Geology and Physical Properties of the Climax Stock, Nevada Test Site. U.S. Geological Survey Open-File Report 77-356, 25 pp. Denver, CO.

Maxey, G. B., 1964. “Hydrostratigraphic Units.” Journal of Hydrology, vol. 2, pp. 124-129.

McArthur, R. D., and N. R. Burkhard, 1986. Geological and Geophysical Investigations of Mid Valley. Lawrence Livermore National Laboratory Report UCID-20740, 91 pp.

Livermore, CA.

McCafferty, A. E., and V. J. S. Grauch, 1997. Aeromagnetic and Gravity Anomaly Maps of the Southwestern Nevada Volcanic Field, Nevada and California. U.S. Geological Survey Geophysical Investigation Map GP-1015, scale 1:250,000. Washington, DC.

McKay, E. J., and K. A. Sargent, 1970. “Geologic Map of the Lathrop Wells Quadrangle, Nye County, Nevada.” U.S. Geological Survey Geologic Quadrangle Map GQ-883, scale 1:24,000. Washington, DC.

McKay, E. J., and W. P. Williams, 1964. “Geologic Map of the Jackass Flats Quadrangle, Nye County, Nevada.” U.S. Geological Survey Geologic Quadrangle Map GQ-368, scale 1:24,000. Washington, DC.

McKeown, F. A., D. L. Healey, and C. H. Miller, 1976. “Geologic Map of the Yucca Lake Quadrangle, Nye County, Nevada.” U.S. Geological Survey, GQ-1327, scale 1:24,000. Washington, DC.

Naeser, C. W., and F. Maldonado, 1981. Fission-Track Dating of the Climax and Gold Meadows Stocks, Nye County, Nevada. In: Short Contributions to Geochronology: U.S. Geological Survey Professional Paper 1199E, pp. 45-47.

National Security Technologies, LLC, 2007. A Hydrostratigraphic Model and Alternatives for the Groundwater Flow and Contaminant Transport Model of Corrective Action Unit 99: Rainier Mesa-Shoshone Mountain, Nye County, Nevada. DOE/NV/25946--146. Las Vegas, NV.

Nevada Bureau of Mines and Geology, 1996. County Digital Geologic Mapping Project- Final Report. Open-File Report 97-1, scale 1:250,000.

NNSA/NSO, see U.S. Department of Energy, National Nuclear Security Administration Nevada Site Office.

Noble, D. C., R. D. Krushensky, E. J. McKay, and J. R. Ege, 1967. “Geologic Map of the Dead Horse Flat Quadrangle, Nye County, Nevada.” U.S. Geological Survey Geologic Quadrangle Map GQ-614, scale 1:24,000. Washington, DC.

NSTec, see National Security Technologies, LLC. 
O’Connor, J. T., R. E. Anderson, and P. W. Lipman, 1966. “Geologic Map of the Thirsty Canyon Quadrangle, Nye County, Nevada.” U.S. Geological Survey Geologic Quadrangle Map GQ-524, scale 1:24,000. Washington, DC.

Orkild, P. P., 1963. “Geologic Map of the Tippipah Spring Quadrangle, Nye County, Nevada.” U.S. Geological Survey, Quadrangle Map GQ-213, scale 1:24,000. Washington, DC.

Orkild, P. P., 1968. “Geologic Map of the Mine Mountain Quadrangle, Nye County, Nevada.” U.S. Geological Survey, Quadrangle Map GQ-746, scale 1:24,000. Washington, DC.

Orkild, P. P., and J. T. O’Connor, 1970. “Geologic Map of the Topopah Spring Quadrangle, Nye County, Nevada.” U.S. Geological Survey Geologic Quadrangle Map GQ-849, scale 1:24,000. Washington, DC.

Orkild, P. P., D. R. Townsend, and M. J. Baldwin, 1983. “Geologic Investigations.” In: Geologic and Geophysical Investigations of Climax Stock Intrusive, Nevada. U.S. Geological Survey Open-File Report 83-377, pp. 1-24. Denver, CO.

Pawloski, G. A., A. F. B. Tompson, C. J. Bruton, and M. Zavarin, eds., 2000. Evaluation of the Hydrologic Source Term from Underground Nuclear Tests in Frenchman Flat at the Nevada Test Site. Contributors: W. L. Bourcier, C. J. Bruton, S. F. Carle, B. K. Esser, A. B. Kersting, R. M. Maxwell, G. A. Pawloski, J. A. Rard, D. E. Shumaker, D. K. Smith, A. F. B. Tompson, and M. Zavarin. Lawrence Livermore National Laboratory Report UCRL-ID-138007. Livermore, CA.

Phelps, G. A., R. C. Jachens, B. C. Moring, and C. W. Roberts, 2004. Modeling of Climax Stock and Related Plutons Based on the Inversion of Magnetic Data, Southwest Nevada. U.S. Geological Survey Open-File Report OFR-2004-1345, 21 pp. Denver, CO.

Ponce, D. A., 1999. Digital Aeromagnetic Map of the Nevada Test Site Area, Nye, Lincoln, and Clark Counties, Nevada and Inyo County, California. U.S. Geological Survey Open-File Report 99-55413, CD-ROM, scale 1:100,000.

Ponce, D. A., R. N. Harris, and H. W. Oliver, 1988. Isostatic Gravity Map of the Nevada Test Site and Vicinity, Nevada. U.S. Geological Survey Open-File Report 88-664. Denver, CO.

Ponce, D. A., E. A. Mankinen, J. G. Davidson, R. L. Morin, and R. J. Blakely, 1999. Digital Isostatic Gravity Map of the Nevada Test Site Area, Nye, Lincoln, Clark Counties, Nevada and Inyo County, California. U.S. Geological Survey Open-File Report 99-554c, CD-ROM, scale 1:100,000.

Poole, F. G., 1965. “Geologic Map of the Frenchman Flat Quadrangle, Nye, Lincoln, and Clark Counties, Nevada.” U.S. Geological Survey Geologic Quadrangle Map GC-456, scale 1:24,000. Washington, DC.

Poole, F. G., D. P. Elston, and W. J. Carr, 1965. “Geologic Map of the Cane Spring Quadrangle, Nye County, Nevada.” U.S. Geological Survey Geologic Quadrangle Map GQ-455, scale 1:24,000. Washington, DC. 
Prothro, L. B., 2005. Mineralogic Zonation Within the Tuff Confining Unit, Yucca Flat, Nevada Test Site. DOE/NV/11718--995. Bechtel Nevada, Las Vegas, NV.

Prothro, L. B., 2008. Analysis of Fractures in Cores from the Tuff Confining Unit beneath Yucca Flat, Nevada Test Site. DOE/NV/25946--351. Las Vegas, NV.

Prothro, L. B., and S. L. Drellack, Jr., 1997. Nature and Extent of Lava-Flow Aquifers Beneath Pahute Mesa, Nevada Test Site. Prepared for U.S. Department of Energy, National Nuclear Security Administration Nevada Site Office by Bechtel Nevada, Las Vegas, NV.

Raytheon Services Nevada, 1990. "Nevada Test Site Drilling and Mining Summary.” Available from Bechtel Nevada, Mercury, NV.

Reiner, S. R., G. L. Locke, and L. S. Robie. 1995. Ground-Water Data for the Nevada Test Site and Selected Other Areas in South-Central Nevada 1992-1993. U.S. Geological Survey Open-File Report 95-160.

Rogers, C. L., and D. C. Noble, 1969. "Geologic Map of the Oak Spring Butte Quadrangle, Nye County, Nevada.” U.S. Geological Survey Map GQ-822, scale 1:24,000. Washington, DC.

Russell, C. E., D. Gillespie, J. C. Cole, S. L. Drellack, L. B. Prothro, P. H. Thompson, R. L. McCall, G. A. Pawloski, and R. Carlson, 1996. Completion Report for Well ER-12-1. DOE/NV/10845--36. Prepared for U.S. Department of Energy Nevada Operations Office, Las Vegas, NV.

Sargent, K. A., and J. H. Stewart, 1971. "Geologic Map of the Specter Range NW Quadrangle, Nye County, Nevada.” U.S. Geological Survey Map GQ-884, scale 1:24,000. Washington, DC.

Sargent, K. A., S. J. Luft, A. B. Gibbons, and D. L. Hoover, 1966. “Geologic Map of the Quartet Dome Quadrangle, Nye County, Nevada.” U.S. Geological Survey Map GQ-496, scale 1:24,000. Washington, DC.

Sargent, K. A., E. J. McKay, and B. C. Burchfiel, 1970. "Geologic Map of the Striped Hills Quadrangle, Nye County, Nevada.” U.S. Geological Survey Map GQ-882, scale 1:24,000. Washington, DC.

Sawyer, D. A., R. J. Fleck, M. A. Lanphere, R. G. Warren, D. E. Broxton, and M. R. Hudson, 1994. "Episodic Caldera Volcanism in the Miocene Southwest Nevada Volcanic Field: Revised Stratigraphic Framework, ${ }^{40} \mathrm{Ar} /{ }^{39} \mathrm{Ar}$ Geochronology and Implications for Magmatism and Extension.” Geological Society of America Bulletin, v. 106, pp. 1304-1318.

Seaber, P. R., 1988. "Hydrostratigraphic Units.” In: Back, W., J. R. Rosenshein, and P. R. Seaber, eds., Hydrogeology: The Geology of North America, Geological Society of America, vol. O-2, pp. 9-14. 
Slate, J. L., M. E. Berry, P. D. Rowley, C. J. Fridrich, K. S. Morgan, J. B. Workman, O. D. Young, G. L. Dixon, V. S. Williams, E. H. McKee, D. A. Ponce, T. G. Hildenbrand, WC Swadley, S. C. Lundstrom, E. B. Ekren, R. G. Warren, J. C. Cole, R. J. Fleck, M. A. Lanphere, D. A. Sawyer, S. A. Minor, D. J. Grunwald, R. J. Laczniak, C. M. Menges, J. C. Yount, and A. S. Jayko, 1999. Digital Geologic Map of the Nevada Test Site and Vicinity, Nye, Lincoln, and Clark Counties, Nevada and Inyo County, California. U.S. Geological Survey Open-File Report 99B554BA, scale 1:120,000.

Smith, R. L., 1960. “Ash Flows.” Geological Society of America Bulletin, vol. 71, no. 6, pp. 795-842.

Snyder, R. P., 1977. Geology of the Gold Meadows Stock, Nevada Test Site. U.S. Geological Survey Report 474-179, 10 pp. Denver, CO.

Stoller-Navarro Joint Venture, 2005. Phase II Contaminant Transport Parameters for the Groundwater Flow and Contaminant Transport Model of Corrective Action Unit 98: Frenchman Flat, Nye County, Nevada. S-N/99205--043. Las Vegas, NV

Stoller-Navarro Joint Venture, 2007. Phase I Contaminant Transport Parameters for the Groundwater Flow and Contaminant Transport Model of Corrective Action Unit 97: Yucca Flat/Climax Mine, Nevada Test Site, Nye County, Nevada, Revision No. 0. S-N/99205--096. Las Vegas, NV.

Stoller-Navarro Joint Venture, 2008. Phase I Contaminant Transport Parameters for the Groundwater Flow and Contaminant Transport Model of Corrective Action Unit 99: Rainier Mesa/Shoshone Mountain, Nevada Test Site, Nye County, Nevada. S-N/99205-102. Las Vegas, NV

Swadley, WC, and W. J. Carr, 1987. “Geologic Map of the Quaternary and Tertiary Deposits of the Big Dune Quadrangle, Nye County, Nevada, and Inyo County, California.” U.S. Geological Survey Miscellaneous Investigations Map I-1767, scale 1:48,000. Washington, DC.

Tompson, A. F. B., C. J. Bruton, and G. A. Pawloski, 1999. Evaluation of the Hydrologic Source Term from the Underground Nuclear Tests in Frenchman Flat at the Nevada Test Site: The CAMBRIC Test. UCRL-ID-132300. Lawrence Livermore National Laboratory. Livermore, CA.

U.S. Department of Energy, Nevada Operations Office, 1995a. Completion Report for Well ER-3-1. DOE/NV--396. Prepared by IT Corporation, Las Vegas, NV.

U.S. Department of Energy, Nevada Operations Office, 1995b. Completion Report for Well ER-3-2. DOE/NV--408. Prepared by IT Corporation, Las Vegas, NV.

U.S. Department of Energy, Nevada Operations Office, 1995a. Completion Report for Well ER-19-1. DOE/NV/11718--410. Prepared by IT Corporation, Las Vegas, NV. 
U.S. Department of Energy, Nevada Operations Office, 1995b. Completion Report for Well ER-30-1. DOE/NV--407. Prepared by IT Corporation, Las Vegas, NV.

U.S. Department of Energy, Nevada Operations Office, 1996. Final Environmental Impact Statement for the Nevada Test Site and Off-Site Locations in the State of Nevada. DOE/EIS 0243. Las Vegas, NV.

U.S. Department of Energy, Nevada Operations Office, 1997. Completion Report for Well Cluster ER-20-5. DOE/NV--486. Prepared by IT Corporation, Las Vegas, NV.

U.S. Department of Energy, Nevada Operations Office, 1998. Completion Report for Well Cluster ER-20-6. DOE/NV--467. Prepared by IT Corporation, Las Vegas, NV.

U.S. Department of Energy, Nevada Operations Office, 2000a. Completion Report for Well ER-EC-6. DOE/NV/11718--360. Prepared by Bechtel Nevada, Las Vegas, NV.

U.S. Department of Energy, Nevada Operations Office, 2000b. Completion Report for Well ER-EC-1. DOE/NV/11718--381. Prepared by Bechtel Nevada, Las Vegas, NV.

U.S. Department of Energy, Nevada Operations Office, 2000c. Completion Report for Well ER-EC-4. DOE/NV/11718--397. Prepared by Bechtel Nevada, Las Vegas, NV.

U.S. Department of Energy, Nevada Operations Office, 2002. Completion Report for Well ER-EC-2A. DOE/NV/11718--591. Prepared by Bechtel Nevada, Las Vegas, NV.

U.S. Department of Energy, National Nuclear Security Administration Nevada Site Office, 2003. Well Completion Report for Well ER-18-2. DOE/NV/11718--388. Prepared by Bechtel Nevada, Las Vegas, NV.

U.S. Department of Energy, National Nuclear Security Administration Nevada Site Office, 2004a. Well Completion Report for Well ER-EC-5. DOE/NV/11718--424. Prepared by Bechtel Nevada, Las Vegas, NV.

U.S. Department of Energy, National Nuclear Security Administration Nevada Site Office, 2004b. Well Completion Report for Well ER-EC-8. DOE/NV/11718--435. Prepared by Bechtel Nevada, Las Vegas, NV.

U.S. Department of Energy, National Nuclear Security Administration Nevada Site Office, 2004c. Well Completion Report for Well ER-EC-7. DOE/NV/11718--467. Prepared by Bechtel Nevada, Las Vegas, NV.

U.S. Department of Energy, National Nuclear Security Administration Nevada Site Office, 2004d. Well Completion Report for Well ER-8-1. DOE/NV/11718--845. Prepared by Bechtel Nevada, Las Vegas, NV.

U.S. Department of Energy, National Nuclear Security Administration Nevada Site Office, 2004e. Completion Report for Well ER-12-2. DOE/NV/11718--846. Prepared by Bechtel Nevada, Las Vegas, NV. 
U.S. Department of Energy, National Nuclear Security Administration Nevada Site Office, $2004 \mathrm{f}$. Well Completion Report for Well Cluster ER-6-1. DOE/NV/11718--862. Prepared by Bechtel Nevada, Las Vegas, NV.

U.S. Department of Energy, National Nuclear Security Administration Nevada Site Office, 2004g. Well Completion Report for Well ER-7-1. DOE/NV/11718--865. Prepared by Bechtel Nevada, Las Vegas, NV.

U.S. Department of Energy, National Nuclear Security Administration Nevada Site Office, 2004h. Well Completion Report for Well ER-2-1. DOE/NV/11718--893. Prepared by Bechtel Nevada, Las Vegas, NV.

U.S. Department of Energy, National Nuclear Security Administration Nevada Site Office, 2005a. Well Completion Report for Well Cluster ER-5-3. DOE/NV/11718--1093. Prepared by Bechtel Nevada, Las Vegas, NV.

U.S. Department of Energy, National Nuclear Security Administration Nevada Site Office, 2005b. Well Completion Report for Well Cluster ER-5-4. DOE/NV/11718--998. Prepared by Bechtel Nevada, Las Vegas, NV.

U.S. Department of Energy, National Nuclear Security Administration Nevada Site Office, 2006a. Completion Report for Well ER-12-3. DOE/NV/11718--1182. Prepared by Bechtel Nevada, Las Vegas, NV.

U.S. Department of Energy, National Nuclear Security Administration Nevada Site Office, 2006b. Completion Report for Well ER-12-4. DOE/NV--1128. Prepared by Bechtel Nevada, Las Vegas, NV.

U.S. Department of Energy, National Nuclear Security Administration Nevada Site Office, 2006c. Completion Report for Well ER-16-1. DOE/NV--1180. Prepared by National Security Technologies, LLC, Las Vegas, NV.

U.S. Department of Energy, National Nuclear Security Administration Nevada Site Office, 2008. Completion Report for the Well ER-6-2 Site, Corrective Action Unit 97: Yucca Flat-Climax Mine. DOE/NV--1270. Prepared by National Security Technologies, Las Vegas, NV.

USGS, see U.S. Geological Survey.

U.S. Geological Survey, 1991. Suggestions to Authors of the Reports of the United States Geological Survey. Hansen, W. R., ed. U.S. Government Printing Office, Washington, DC.

Waddell, R. K., J. H. Robison, and R. K. Blankennagel, 1984. Hydrology of Yucca Mountain and Vicinity, Nevada-California Investigative Results through Mid-1983. U.S. Geological Survey Water-Resources Investigation Report 84-4267, 72 pp. Denver, CO.

Wagoner, J. L., and W. Richardson, 1986. Stratigraphic Contacts From Drill Holes at the Nevada Test Site. Lawrence Livermore National Laboratory Report UCID-20790, 39 pp. Livermore, CA. 
Walker, G. E., 1962. Ground Water in the Climax Stock, Nevada Test Site, Nye County, Nevada. U.S. Geological Survey Trace Elements Investigations Report TEI-813, 48 pp. Washington, DC.

Warren, R. G., D. A. Sawyer, F. M. Byers, Jr., and J. C. Cole, 2003. A Petrographical, Geochemical and Geophysical Database and Framework for the Southwestern Nevada Volcanic Field. Los Alamos National Laboratory Report LA-UR-03-1503. Los Alamos, NM.

Winograd, I. J., and W. Thordarson, 1975. Hydrogeologic and Hydrochemical Framework, South-Central Great Basin, Nevada-California, with Special Reference to the Nevada Test Site. U.S. Geological Survey Professional Paper 712-C, 126 pp. Washington, DC.

Workman, J. B., C. Menges, W. R. Page, E. M. Taylor, E. B. Ekren, P. P. Rowley, G. L. Dixon, R. A. Thompson, and L. A. Wright, 2002. Geologic Map of the Death Valley Groundwater Model Area, Nevada and California. U.S. Geological Survey Miscellaneous Map MF-2381-A, scale 1:250,000. Washington, DC.

Zavarin, M., S. F. Carle, and R. M. Maxwell, 2004. Upscaling Radionuclide RetardationLinking the Surface Complexation and Ion Exchange Mechanistic Approach to a Linear Kd Approach. Report on Work Performed for the UGTA Program. Lawrence Livermore National Laboratory Report UCRL-TR-214713. Livermore, CA. 


\section{Distribution List}

\section{$\underline{\text { Copies }}$}

W. R. Wilborn

U.S. Department of Energy

1 paper/1 CD

National Nuclear Security Administration

Nevada Site Office

Environmental Restoration Division

P.O. Box 98518, M/S 505

Las Vegas, NV 89193-8518

U.S. Department of Energy

National Nuclear Security Administration

$1 \mathrm{CD}$ (uncontrolled)

Nevada Site Office

Technical Library

P.O. Box 98518, M/S 505

Las Vegas, NV 89193-8518

U.S. Department of Energy

National Nuclear Security Administration

2 CDs (uncontrolled)

Nevada Site Office

Public Reading Facility

c/o Nuclear Testing Archive

P.O. Box 98521, M/S 400

Las Vegas, NV 89193-8521

U.S. Department of Energy

Office of Scientific and Technical Information

1 electronic copy (uncontrolled)

P.O. Box 62

Oak Ridge, TN 378831-0061

N. M. Becker

Los Alamos National Laboratory

P.O. Box 1663, EES-6, M/S T-003

Los Alamos, NM 87545-1663

B. M. Crowe

Environmental Restoration Project

U.S. Department of Energy

National Nuclear Security Administration

Nevada Site Office

P.O. Box 98518, M/S 505

Las Vegas, NV 89193-8518

E. M. Kwicklis

Los Alamos National Laboratory

P. O. Box 1663

Los Alamos, NM 87545-1663

$1 \mathrm{CD}$

1 paper/1 CD

1 paper/1 CD 


\section{Distribution List}

$\underline{\text { Copies }}$

S. Marutzky

Stoller-Navarro Joint Venture

1 paper/1CD

232 Energy Way, M/S 439

Las Vegas, NV 89129

P. K. Ortego

National Security Technologies, LLC

1 paper/1 CD

P.O. Box 98521, NLV082

Las Vegas, NV 89193-8521

G. A. Pawloski

Lawrence Livermore National Laboratory

1 paper/ 1CD

P.O. Box 808

Livermore, CA 94551-0808

G. Ruskauff

Stoller-Navarro Joint Venture

$1 \mathrm{CD}$

232 Energy Way, MS 439

North Las Vegas, NV 89030

C. E. Russell

Desert Research Institute

1 paper/1 CD

755 East Flamingo Road

P.O. Box 19040

Las Vegas, NV 89119-7363

Stoller-Navarro Library

Stoller-Navarro Joint Venture

232 Energy Way, M/S 439

North Las Vegas, NV 89030

B. K. Thompson

Water Resources, Nevada District

U.S. Geological Survey

160 N. Stephanie Street

Henderson, NV 89074

A. V. Wolfsberg

$1 \mathrm{CD}$

Los Alamos National Laboratory

$1 \mathrm{CD}$

P. O. Box 1663, EES-6, M/S T003

Los Alamos, NM 87545-1663

M. Zavarin

$1 \mathrm{CD}$

Lawrence Livermore National Laboratory

P. O. Box 808

Livermore, CA 94551-0808

Dist-2 


\section{APPENDIX A}

Hydrostratigraphic Units of UGTA CAU-Scale Hydrostratigraphic Framework Models 



\section{Table A-1}

Hydrostratigraphic Units of UGTA CAU-Scale Hydrostratigraphic Framework Models

(Compiled from BN, 2002; 2005; 2006; NSTec, 2007)

\begin{tabular}{|c|c|c|c|}
\hline $\begin{array}{l}\text { Hydrostratigraphic Unit } \\
\text { (Symbol) }\end{array}$ & $\begin{array}{c}\text { Dominant } \\
\begin{array}{c}\text { Hydrogeologic } \\
\text { Unit(s) }^{\mathrm{a}}\end{array}\end{array}$ & $\begin{array}{l}\text { Stratigraphic } \\
\text { Units }^{b}\end{array}$ & General Description \\
\hline $\begin{array}{l}\text { Alluvial aquifer } \\
\qquad \text { (AA) }\end{array}$ & AA & $\begin{array}{l}\text { Qay, QTc, Qs, } \\
\text { QTa, QTu, Qb, } \\
\text { Tgy, Tgc, Tgy, Tt }\end{array}$ & $\begin{array}{l}\text { Consists mainly of alluvium that fills extensional basins including Yucca Flat, Frenchman Flat, } \\
\text { Gold Flat, Crater Flat, Kawich Valley, and Sarcobatus Flat. In the northwest also includes } \\
\text { generally older Tertiary gravels, tuffaceous sediments, and nonwelded tuffs (where thin) that } \\
\text { partially fill other basins such as Oasis Valley and the moat of the Timber Mountain caldera } \\
\text { complex. }\end{array}$ \\
\hline $\begin{array}{l}\text { Playa confining unit } \\
\text { (PCUT) }\end{array}$ & PCU & Qp & $\begin{array}{l}\text { Clayey silt and sandy silt. Forms the surface and near-surface playas (dry lake beds) at } \\
\text { Frenchman Flat, Yucca Flat, and Papoose Lake. }\end{array}$ \\
\hline $\begin{array}{l}\text { Basalt lava-flow aquifer } \\
\text { (BLFA) }\end{array}$ & LFA & Tyb, Tybp & Subsurface occurrences of Pliocene basalt in Yucca Flat and northern Frenchman Flat. \\
\hline $\begin{array}{l}\text { Older altered alluvial } \\
\text { aquifer } \\
\text { (OAA and OAA1) }\end{array}$ & AA & QTa & $\begin{array}{l}\text { Older, denser, zeolitic alluvium recognized only in northern Frenchman Flat. OAA and OAA1 are } \\
\text { equivalent except for position: the OAA is above the BLFA, and the OAA1 is stratigraphically } \\
\text { beneath the BLFA. }\end{array}$ \\
\hline $\begin{array}{l}\text { Older playa confining unit } \\
\text { (PCU1U and PCU1L) }\end{array}$ & PCU & QTp & $\begin{array}{l}\text { Deep, subsurface playa deposits in the deepest portion of Frenchman Flat. Recognized in Well } \\
\text { ER-5-4\#2 and 3-D seismic data. The PCU1U and PCU1L are similar except for position. }\end{array}$ \\
\hline $\begin{array}{l}\text { Younger volcanic } \\
\text { composite unit } \\
\text { (YVCM) }\end{array}$ & LFA, WTA, VTA & $\begin{array}{l}\text { Typ, Tgy, Ts, Tyb, } \\
\text { Tyr }\end{array}$ & $\begin{array}{l}\text { A minor unsaturated HSU that consists of Pliocene to late Miocene basaltic rocks such as those } \\
\text { at Thirsty Mountain and Buckboard Mesa. Also includes welded and nonwelded ash-flow tuff of } \\
\text { the Volcanics of Stonewall Mountain. Mainly occurs in the northwestern portion of the Pahute } \\
\text { Mesa-Oasis Valley (PM-OV) model area. }\end{array}$ \\
\hline $\begin{array}{l}\text { Thirsty Canyon } \\
\text { volcanic aquifer } \\
\text { (TCVA) }\end{array}$ & $\begin{array}{l}\text { WTA, LFA, } \\
\text { lesser VTA }\end{array}$ & $\begin{array}{l}\text { Tth, Ttg, Tts, Ttt, } \\
\text { Ttp, Ttc }\end{array}$ & $\begin{array}{l}\text { Consists mainly of welded ash-flow tuff and lava of the Thirsty Canyon Group. Unit is very thick } \\
\text { within the Black Mountain caldera. Also is present east and south of the caldera, including the } \\
\text { northwestern moat area of the Timber Mountain caldera complex and the northern portion of the } \\
\text { Oasis Valley basin. }\end{array}$ \\
\hline $\begin{array}{l}\text { Detached volcanics } \\
\text { aquifer } \\
\text { (DVA) }\end{array}$ & WTA, LFA & Tf, Tma, Tmr & $\begin{array}{l}\text { Consists of welded ash-flow tuff and lava assigned to the Ammonia Tanks Tuff and units of the } \\
\text { Volcanics of Fortymile Canyon. Although, like the DVCM, the DVA also overlies the Fluorspar } \\
\text { Canyon-Bullfrog Hills detachment fault, it is considered a separate HSU because of the } \\
\text { preponderance of welded-tuff and lava-flow aquifers that compose the HSU and much smaller } \\
\text { degree of alteration present. }\end{array}$ \\
\hline $\begin{array}{l}\text { Detached volcanics } \\
\text { composite unit } \\
\text { (DVCM) }\end{array}$ & $\begin{array}{l}\text { WTA, LFA, } \\
\text { TCU }\end{array}$ & Tf through Tq & $\begin{array}{l}\text { Consists of a very complex distribution of lavas and tuffs that form a relatively thin, highly } \\
\text { extended interval above the Fluorspar Canyon-Bullfrog Hills detachment fault in the southwestern } \\
\text { portion of the PM-OV model area. }\end{array}$ \\
\hline
\end{tabular}


Table A-1

Hydrostratigraphic Units of UGTA CAU-Scale Hydrostratigraphic Framework Models (continued)

\begin{tabular}{|c|c|c|c|}
\hline $\begin{array}{l}\text { Hydrostratigraphic Unit } \\
\text { (Symbol) }\end{array}$ & $\begin{array}{l}\text { Dominant } \\
\text { Hydrogeologic } \\
\text { Unit(s) }\end{array}$ & $\begin{array}{l}\text { Stratigraphic } \\
\text { Units }\end{array}$ & General Description \\
\hline $\begin{array}{l}\text { Fortymile Canyon } \\
\text { composite unit } \\
\text { (FCCM) }\end{array}$ & $\begin{array}{l}\text { LFA, TCU, } \\
\text { lesser WTA }\end{array}$ & $\begin{array}{l}\text { Tfu, Tfs, Tfd, Tfr, } \\
\text { Tfb, Tfl, Tff }\end{array}$ & $\begin{array}{l}\text { Consists of a complex and poorly understood distribution of lava and associated tuff of the } \\
\text { Volcanics of Fortymile Canyon. Generally confined within the moat of the Timber Mountain } \\
\text { caldera complex, where the unit forms a ring around Timber Mountain. Unit is also present in } \\
\text { areas southwest of the Timber Mountain caldera complex. }\end{array}$ \\
\hline $\begin{array}{l}\text { Fortymile Canyon aquifer } \\
\text { (FCA) }\end{array}$ & WTA, LFA & Tff, Tfbc & $\begin{array}{l}\text { Composed mainly of welded ash-flow tuff and rhyolitic lava, and is generally less than } 305 \mathrm{~m} \\
(1,000 \mathrm{ft}) \text { thick. Occurs in the subsurface in the southwestern portion of the Timber Mountain } \\
\text { caldera complex. }\end{array}$ \\
\hline $\begin{array}{l}\text { Tannenbaum Hill } \\
\text { lava-flow aquifer } \\
\quad(\text { THLFA) }\end{array}$ & LFA & Tmat & $\begin{array}{l}\text { Composed entirely of rhyolitic lava of the rhyolite of Tannenbaum Hill. Exposed at the surface just } \\
\text { outside the northwestern structural boundary of the Timber Mountain caldera complex. } \\
\text { Tannenbaum Hill lava occurring inside the caldera complex is grouped with the TMCM. }\end{array}$ \\
\hline $\begin{array}{l}\text { Tannenbaum Hill } \\
\text { composite unit } \\
\text { (THCM) }\end{array}$ & $\begin{array}{l}\text { Mostly TCU, } \\
\text { lesser WTA }\end{array}$ & Tmat & $\begin{array}{l}\text { Zeolitic tuff and lesser welded ash-flow tuff of the rhyolite of Tannenbaum Hill that occurs } \\
\text { stratigraphically below Tannenbaum Hill lava and above the rhyolite of Fluorspar Canyon. } \\
\text { Distribution is similar to the THLFA. }\end{array}$ \\
\hline $\begin{array}{l}\text { Timber Mountain upper } \\
\text { vitric-tuff aquifer } \\
\text { (TM-UVTA) }\end{array}$ & $\begin{array}{l}\text { VTA, } \\
\text { minor WTA }\end{array}$ & Tma, Tmab & $\begin{array}{l}\text { Typically saturated only in the deepest structural basins (i.e., Yucca Flat and Mid Valley). This } \\
\text { HSU comprises only the nonwelded to partially welded Ammonia Tanks Tuff, which } \\
\text { stratigraphically overlies the TM-WTA in Yucca Flat and Mid Valley. }\end{array}$ \\
\hline $\begin{array}{l}\text { Timber Mountain welded- } \\
\text { tuff aquifer } \\
\text { (TM-WTA) }\end{array}$ & $\begin{array}{l}\text { WTA } \\
\text { minor VTA }\end{array}$ & $\begin{array}{l}\text { Tma, Tmab, } \\
\text { Tmrb, Tmr }\end{array}$ & $\begin{array}{l}\text { Consists mainly of out-flow sheets of Ammonia Tanks and Timber Mountain welded ash-flow tuff. } \\
\text { Also includes minor bedded tuff (Tmab and Tmrb) that occurs between Ammonia Tanks and } \\
\text { Timber Mountain ash-flow tuffs. This is an extensive HSU that occurs in many parts of the NTS } \\
\text { region. Typically saturated only in the deeper portions of Yucca Flat, Frenchman Flat, and Mid } \\
\text { Valley. Equivalent to the TMA in the PM-OV model area. }\end{array}$ \\
\hline $\begin{array}{l}\text { Timber Mountain lower } \\
\text { vitric-tuff aquifer } \\
\text { (TM-LVTA) }\end{array}$ & VTA & $\begin{array}{l}\text { Tma, Tmab, Tmr, } \\
\text { Tmrh, Tp, Th, Tw, } \\
\text { Tc; may also } \\
\text { include Tbgb and } \\
\quad \text { Tn }\end{array}$ & $\begin{array}{l}\text { Typically includes the nonzeolitized, nonwelded lower portion of the Rainier Mesa Tuff and post- } \\
\text { Tunnel Formation units. However, in places this HSU encompasses all vitric (i.e., non-zeolitized), } \\
\text { nonwelded and bedded units below the welded Rainier Mesa Tuff and above the upper level of } \\
\text { pervasive zeolitization. Typically occurs above the level of saturation because vitric, nonwelded } \\
\text { tuffs tend to zeolitize under saturated conditions. }\end{array}$ \\
\hline $\begin{array}{l}\text { Fluorspar Canyon } \\
\text { confining unit (FCCU) }\end{array}$ & TCU & Tmrf & $\begin{array}{l}\text { Consists of zeolitic, nonwelded tuff of the rhyolite of Fluorspar Canyon that generally occurs } \\
\text { beneath the THCM, and thus has a similar distribution. }\end{array}$ \\
\hline $\begin{array}{l}\text { Windy Wash aquifer } \\
\text { (WWA) }\end{array}$ & LFA & Tmw & $\begin{array}{l}\text { Minor HSU consisting of the lava-flow lithofacies of the rhyolite of Windy Wash. Occurs along the } \\
\text { western (down-thrown) side of the West Greeley fault in Area } 20 .\end{array}$ \\
\hline
\end{tabular}


Table A-1

Hydrostratigraphic Units of UGTA CAU-Scale Hydrostratigraphic Framework Models (continued)

\begin{tabular}{|c|c|c|c|}
\hline $\begin{array}{l}\text { Hydrostratigraphic Unit } \\
\text { (Symbol) }\end{array}$ & $\begin{array}{l}\text { Dominant } \\
\text { Hydrogeologic } \\
\text { Unit(s) }^{\text {a }}\end{array}$ & $\begin{array}{l}\text { Stratigraphic } \\
\text { Units }\end{array}$ & General Description \\
\hline $\begin{array}{l}\text { Timber Mountain } \\
\text { composite unit } \\
\text { (TMCM) }\end{array}$ & $\begin{array}{l}\text { WTA; lesser } \\
\text { TCU and LFA }\end{array}$ & $\begin{array}{l}\text { Tmay, Tmaw, } \\
\text { Tma, Tmc, Tmat, } \\
\text { Tmr }\end{array}$ & $\begin{array}{l}\text { Consists mainly of intra-caldera, strongly welded ash-flow tuff of the Timber Mountain Group, and } \\
\text { is confined within the Timber Mountain caldera complex. Although consisting mainly of strongly } \\
\text { welded tuff, which is assumed to be considerably fractured and thus behave as an aquifer, the } \\
\text { TMCM is designated a composite unit because of the potential for hydrothermal alteration within } \\
\text { this deep intra-caldera setting. Alteration would have significantly altered the hydraulic properties } \\
\text { of the rocks, particularly filling fractures with secondary minerals such as quartz. }\end{array}$ \\
\hline $\begin{array}{l}\text { Timber Mountain aquifer } \\
\text { (TMA) }\end{array}$ & $\begin{array}{l}\text { Mostly WTA, } \\
\text { minor VTA }\end{array}$ & $\begin{array}{l}\text { Tma, Tmab, Tmr, } \\
\text { Tmrb }\end{array}$ & $\begin{array}{l}\text { Consists mainly of extra-caldera welded ash-flow tuffs of Ammonia Tanks Tuff and Rainier Mesa } \\
\text { Tuff. These rocks are the extra-caldera equivalent of the rocks comprising the TMCM. Unit } \\
\text { occurs mostly north and west of the Timber Mountain caldera complex. The TMA in the PM-OV } \\
\text { model area is equivalent to the TM-WTA. }\end{array}$ \\
\hline $\begin{array}{l}\text { Rainier Mesa breccia } \\
\text { confining unit } \\
\text { (RMBCU) }\end{array}$ & TCU/AA & Tmc & $\begin{array}{l}\text { Breccia deposits formed by sloughing of the caldera wall during formation of the Rainier Mesa } \\
\text { caldera. Consists of angular clasts of volcanic rocks older than the Rainier Mesa Tuff, within an } \\
\text { argillic, tuffaceous matrix. Modeled as a wedge-shaped volume adjacent to the structural wall of } \\
\text { the Rainier Mesa caldera. Delineated within the Rainier Mesa-Shoshone Mountain (RM-SM) } \\
\text { model only. }\end{array}$ \\
\hline $\begin{array}{l}\text { Sub-caldera volcanic } \\
\text { confining unit } \\
\text { (SCVCU) }\end{array}$ & TCU & $\begin{array}{l}\text { Tm, Tp, Tc, and } \\
\text { older, undifferen- } \\
\quad \text { tiated tuffs }\end{array}$ & $\begin{array}{l}\text { A highly conjectural unit that is modeled as consisting of highly altered volcanic rocks that occur } \\
\text { stratigraphically between the Rainier Mesa Tuff and basement rocks (ATICU and RMICU) within } \\
\text { the deeper portions of the Timber Mountain caldera complex. }\end{array}$ \\
\hline $\begin{array}{l}\text { Benham aquifer } \\
\quad(B A)\end{array}$ & LFA & $\mathrm{Tpb}$ & $\begin{array}{l}\text { Lava-flow lithofacies of the rhyolite of Benham. Occurs north of the Timber Mountain caldera } \\
\text { complex and beneath the southwestern portion of Pahute Mesa. }\end{array}$ \\
\hline $\begin{array}{l}\text { Upper Paintbrush } \\
\text { confining unit } \\
\text { (UPCU) }\end{array}$ & TCU & Pre-Tmr tuffs, Tp & $\begin{array}{l}\text { Includes all zeolitic, nonwelded and bedded tuffs between the rhyolite of Benham lava (i.e., Tpb) } \\
\text { and welded tuff of the Tiva Canyon Tuff (i.e., TCA). Unit occurs in the vicinity of southwestern } \\
\text { Area } 20 .\end{array}$ \\
\hline $\begin{array}{l}\text { Tiva Canyon aquifer } \\
\text { (TCA) }\end{array}$ & WTA & Tpc & The welded ash-flow tuff lithofacies of the Tiva Canyon Tuff. \\
\hline $\begin{array}{l}\text { Paintbrush } \\
\text { composite unit } \\
\quad(P C M)\end{array}$ & $\begin{array}{l}\text { WTA, LFA, } \\
\text { TCU }\end{array}$ & $\mathrm{Tp}$ & $\begin{array}{l}\text { Consists mostly of units of the Paintbrush Group that occur in the southern portion of the PM-OV } \\
\text { model area in the vicinity of the Claim Canyon caldera. Unit is dominated by thick, strongly } \\
\text { welded Tiva Canyon Tuff within the Claim Canyon caldera. Outside the caldera this unit is more } \\
\text { variable, consisting of welded and nonwelded tuff and rhyolitic lava assigned to various formations } \\
\text { of the Paintbrush Group. Stratigraphically equivalent units of the Paintbrush Group that occur } \\
\text { beneath Pahute Mesa have been grouped into seven separate HSUs. }\end{array}$ \\
\hline
\end{tabular}


Table A-1

Hydrostratigraphic Units of UGTA CAU-Scale Hydrostratigraphic Framework Models (continued)

\begin{tabular}{|c|c|c|c|}
\hline $\begin{array}{l}\text { Hydrostratigraphic Unit } \\
\text { (Symbol) }\end{array}$ & $\begin{array}{c}\text { Dominant } \\
\text { Hydrogeologic } \\
\text { Unit(s) }^{\mathrm{a}} \\
\end{array}$ & $\begin{array}{l}\text { Stratigraphic } \\
\text { Units }\end{array}$ & General Description \\
\hline $\begin{array}{l}\text { Paintbrush } \\
\text { vitric-tuff aquifer } \\
\quad \text { (PVTA) }\end{array}$ & VTA & Pre-Tmr tuffs, Tp & $\begin{array}{l}\text { Typically includes all vitric, nonwelded and bedded tuff units below the Rainier Mesa Tuff to the } \\
\text { top of a Paintbrush lava (e.g., Tpb or Tpe) but may extend to base of Paintbrush Tuff in eastern } \\
\text { Area } 19 \text { where Tpe or Tpr lavas are not present. May also include the vitric pumiceous top of the } \\
\text { Tpe lava. Unit occurs in the northern portion of the PM-OV model area beneath Pahute Mesa. In } \\
\text { the RM-SM model, PVTA is restricted to vitric, nonwelded and bedded tuff that occurs between } \\
\text { the TCA and the TSA. }\end{array}$ \\
\hline $\begin{array}{l}\text { Upper tuff confining unit } \\
\text { (UTCU) }\end{array}$ & TCU & $\begin{array}{l}\text { Tmr (lowermost), } \\
\text { Tmrh, Tp }\end{array}$ & $\begin{array}{l}\text { Defined to encompass the zeolitized bedded tuffs which stratigraphically overlie the Topopah } \\
\text { Spring aquifer (TSA). Although some geologic units of the UTCU are laterally continuous with } \\
\text { those of the LTCU, the UTCU is limited areally to extreme southern Yucca Flat and Mid Valley } \\
\text { where the welded Topopah Spring Tuff is an important aquifer present between the two tuff } \\
\text { confining units (UTCU and LTCU). }\end{array}$ \\
\hline $\begin{array}{l}\text { Paintbrush } \\
\text { lava-flow aquifer } \\
\quad(\text { PLFA) }\end{array}$ & LFA & Tpd, Tpe, Tpr & $\begin{array}{l}\text { Lava-flow lithofacies of the rhyolite of Delirium Canyon (Tpd), rhyolite of Echo Peak (Tpe), and } \\
\text { rhyolite of Silent Canyon (Tpr). Also includes moderately to densely welded ash-flow tuff of Tpe. } \\
\text { Unit occurs only beneath Pahute Mesa. }\end{array}$ \\
\hline $\begin{array}{l}\text { lower Paintbrush } \\
\text { confining unit } \\
\quad(\text { LPCU) }\end{array}$ & TCU & Tpe, Tpp, Tpt & $\begin{array}{l}\text { Includes all zeolitic nonwelded and bedded tuffs between TCA and TSA. Unit occurs in the } \\
\text { northern portion of the PM-OV model area beneath Pahute Mesa. }\end{array}$ \\
\hline $\begin{array}{l}\text { Topopah Spring aquifer } \\
\text { (TSA) }\end{array}$ & WTA & Tpt & The welded ash-flow lithofacies of the Topopah Spring Tuff. \\
\hline $\begin{array}{l}\text { Lower vitric-tuff aquifer } \\
\text { (LVTA) }\end{array}$ & VTA & Th (formerly Tac) & $\begin{array}{l}\text { Relatively thin vitric-tuff aquifer unit below the TSA. Grouped with the TM-LVTA where the } \\
\text { Topopah Spring welded ash-flow tuff is not present. }\end{array}$ \\
\hline $\begin{array}{l}\text { Calico Hills } \\
\text { vitric-tuff aquifer } \\
\text { (CHVTA) }\end{array}$ & VTA & Th (Tac) & $\begin{array}{l}\text { Structurally high, vitric, nonwelded tuffs of the Calico Hills Formation. Present beneath the } \\
\text { eastern portion of Area 19. May become partly zeolitic in the lower portions. }\end{array}$ \\
\hline $\begin{array}{l}\text { Calico Hills } \\
\text { vitric composite unit } \\
\text { (CHVCM) }\end{array}$ & VTA, LFA & Th & $\begin{array}{l}\text { Structurally high, lava and vitric nonwelded tuff of the Calico Hills formation. Present beneath the } \\
\text { western portion of Area 19. May become partly zeolitic in the lower portions. }\end{array}$ \\
\hline $\begin{array}{l}\text { Calico Hills zeolitic } \\
\text { composite unit } \\
(\mathrm{CHZCM})\end{array}$ & LFA, TCU & Th & $\begin{array}{l}\text { Complex 3-D distribution of rhyolite lava and zeolitic nonwelded tuff of the Calico Hills Formation. } \\
\text { Present beneath most of eastern and central Area } 20 .\end{array}$ \\
\hline
\end{tabular}


Table A-1

Hydrostratigraphic Units of UGTA CAU-Scale Hydrostratigraphic Framework Models (continued)

\begin{tabular}{|c|c|c|c|}
\hline $\begin{array}{l}\text { Hydrostratigraphic Unit } \\
\text { (Symbol) }\end{array}$ & $\begin{array}{c}\text { Dominant } \\
\begin{array}{c}\text { Hydrogeologic } \\
\text { Unit(s) }\end{array}\end{array}$ & $\begin{array}{l}\text { Stratigraphic } \\
\text { Units }\end{array}$ & General Description \\
\hline $\begin{array}{l}\text { Calico Hills } \\
\text { confining unit } \\
\quad(\mathrm{CHCU})\end{array}$ & $\begin{array}{l}\text { Mostly TCU, } \\
\text { minor LFA }\end{array}$ & Th (Tac) & $\begin{array}{l}\text { Consists mainly of zeolitic nonwelded tuff of the Calico Hills Formation. Present beneath the } \\
\text { western portion of Area } 20 .\end{array}$ \\
\hline $\begin{array}{l}\text { Inlet aquifer } \\
\quad(\mathrm{IA})\end{array}$ & LFA & Tci & $\begin{array}{l}\text { Lava-flow lithofacies of the rhyolite of Inlet. Occurs as two thick, isolated deposits beneath } \\
\text { Pahute Mesa in the northern portion of the PM-OV model area. }\end{array}$ \\
\hline $\begin{array}{l}\text { Wahmonie confining unit } \\
\text { (WCU) }\end{array}$ & $\begin{array}{l}\text { TCU, minor } \\
\text { LFA }\end{array}$ & $\begin{array}{l}\text { Twu, Twm, Twl, } \\
\text { Twls }\end{array}$ & $\begin{array}{l}\text { Mixture of lava flows, debris flows, lahars, ash-flows, and air-falls of the Wahmonie Formation. } \\
\text { Typically zeolitic, argillic, or hydrothermally altered. Grades or interfingers laterally with the LTCU }\end{array}$ \\
\hline $\begin{array}{l}\text { Crater Flat } \\
\text { composite unit } \\
\quad(\mathrm{CFCM})\end{array}$ & $\begin{array}{l}\text { Mostly LFA, } \\
\text { intercalated } \\
\text { with TCU }\end{array}$ & Tcpj, Tcps, Tcg & $\begin{array}{l}\text { Includes welded tuff and lava flow lithofacies of the tuff of Jorum (Tcpj), the rhyolite of Sled } \\
\text { (Tcps), and the andesite of Grimy Gulch (Tcg). Occurs in central Area } 20 \text { in the northern portion } \\
\text { of the PM-OV model area. }\end{array}$ \\
\hline $\begin{array}{l}\text { Crater Flat } \\
\text { confining unit } \\
\quad(\text { CFCU) }\end{array}$ & TCU & Tc & $\begin{array}{l}\text { Includes all zeolitic, nonwelded and bedded units below the Calico Hills Formation (Th) to the top } \\
\text { of the Bullfrog Tuff (Tcb). Occurs mainly in Area } 19 \text { in the northern portion of the PM-OV model } \\
\text { area. }\end{array}$ \\
\hline $\begin{array}{l}\text { Yucca Mountain Calico } \\
\text { Hills lava-flow aquifer } \\
\text { (YMCHLFA) }\end{array}$ & LFA & Th & $\begin{array}{l}\text { Minor HSU in the southwest corner of the RM-SM model area. Consists mainly of rhyolitic lava } \\
\text { flows of the Calico Hills Formation. }\end{array}$ \\
\hline $\begin{array}{l}\text { Yucca Mountain Crater } \\
\text { Flat } \\
\text { composite unit } \\
\text { (YMCFCM) }\end{array}$ & $\begin{array}{l}\text { LFA, WTA, } \\
\text { TCU }\end{array}$ & Tc, Th & $\begin{array}{l}\text { Includes all units of the Crater Flat Group and Calico Hills Formation that occur in the southern } \\
\text { portion of the PM-OV model area in the vicinity of Yucca Mountain. Stratigraphically equivalent } \\
\text { units that occur in other model areas have been grouped into nine separate HSUs. }\end{array}$ \\
\hline $\begin{array}{l}\text { Kearsarge aquifer } \\
\text { (KA) }\end{array}$ & LFA & Tcpk & $\begin{array}{l}\text { Minor HSU that consists of the lava-flow lithofacies of rhyolite of Kearsarge. Unit is present as a } \\
\text { small isolated occurrence in the northeastern portion of the PM-OV model area. }\end{array}$ \\
\hline $\begin{array}{l}\text { Upper tuff confining } \\
\text { unit } 2 \\
\text { (UTCU2) }\end{array}$ & TCU & $\mathrm{Tp}(\mathrm{b}), \mathrm{Tc}$ & $\begin{array}{l}\text { Defined to encompass the zeolitized bedded tuffs which stratigraphically overlie the Stockade } \\
\text { Wash welded-tuff aquifer (SWA). Although some geologic units of the UTCU2 are laterally } \\
\text { continuous with those of the UTCU1, the UTCU2 is limited areally to the Rainier Mesa area where } \\
\text { the welded Stockade Wash Tuff is present within zeolitic bedded tuff confining units (defined here } \\
\text { as UTCU2 and UTCU1). }\end{array}$ \\
\hline $\begin{array}{l}\text { Stockade Wash aquifer } \\
\text { (SWA) }\end{array}$ & WTA & Tcbs & $\begin{array}{l}\text { Consists of partially welded ash-flow tuff of the Stockade Wash Lobe of the Bullfrog Tuff. } \\
\text { Distribution limited to the central portion of the RM-SM model area. }\end{array}$ \\
\hline $\begin{array}{l}\text { Lower vitric-tuff aquifer } 2 \\
\text { (LVTA2) }\end{array}$ & VTA & Tc, Tn & $\begin{array}{l}\text { Relatively thin VTA unit below the SWA. Grouped with the TM-LVTA or LVTA where the SWA } \\
\text { welded ash-flow tuff is not present. }\end{array}$ \\
\hline
\end{tabular}


Table A-1

Hydrostratigraphic Units of UGTA CAU-Scale Hydrostratigraphic Framework Models (continued)

\begin{tabular}{|c|c|c|c|}
\hline $\begin{array}{l}\text { Hydrostratigraphic Unit } \\
\text { (Symbol) }\end{array}$ & $\begin{array}{c}\text { Dominant } \\
\text { Hydrogeologic } \\
\text { Unit(s) }^{\text {a }}\end{array}$ & $\begin{array}{l}\text { Stratigraphic } \\
\text { Units }\end{array}$ & General Description \\
\hline $\begin{array}{l}\text { Bullfrog confining unit } \\
\text { (BFCU) }\end{array}$ & TCU & Tcb & $\begin{array}{l}\text { Major confining unit in the Pahute Mesa area. Unit consists of thick intra-caldera, zeolitic, mostly } \\
\text { nonwelded ash-flow tuff of the Bullfrog Tuff. }\end{array}$ \\
\hline $\begin{array}{l}\text { Upper tuff confining } \\
\text { unit } 1 \\
\text { (UTCU1) }\end{array}$ & $\mathrm{TCU}$ & Th, Tc & $\begin{array}{l}\text { Defined to encompass the zeolitized bedded tuffs which stratigraphically overlie the BRA. } \\
\text { Although some geologic units of the UTCU1 are laterally continuous with those of the LTCU } \\
\text { and/or the UTCU2, the UTCU1 is limited areally to the northern portion of the RM-SM model area } \\
\text { where the welded Grouse Canyon Tuff is present between the two tuff confining units (UTCU1 } \\
\text { and LTCU). }\end{array}$ \\
\hline $\begin{array}{l}\text { Belted Range aquifer } \\
\qquad \text { (BRA) }\end{array}$ & $\begin{array}{l}\text { LFA and WTA, } \\
\text { with lesser TCU }\end{array}$ & Tb, Tbg, Tbs, Tbq & $\begin{array}{l}\text { Consists of welded ash-flow tuff and lava of the Belted Range Group (Tb) above the Grouse } \\
\text { Canyon Tuff (Tbg), but may also include the lava flow lithofacies of the comendite of Split Ridge } \\
\text { (Tbgs) and the comendite of Quartet Dome (Tbq) where present. Occurs in the northern portions } \\
\text { of the RM-SM and Yucca Flat-Climax Mine (YF-CM) model areas. }\end{array}$ \\
\hline $\begin{array}{c}\text { Lower vitric-tuff aquifer } 1 \\
\text { (LVTA1) }\end{array}$ & VTA & Tbgu, Tn4 & $\begin{array}{l}\text { Relatively thin vitric-tuff aquifer unit below the BRA. Grouped with the TM-LVTA or LVTA where } \\
\text { the BRA welded ash-flow tuff is not present. }\end{array}$ \\
\hline $\begin{array}{l}\text { Pre-Belted Range } \\
\text { composite unit } \\
\text { (PBRCM) }\end{array}$ & $\begin{array}{l}\text { TCU, WTA } \\
\text { LFA }\end{array}$ & $\begin{array}{l}\text { Tr, Tn, Tq, Tu, To, } \\
\text { Tk, Te }\end{array}$ & $\begin{array}{l}\text { Laterally extensive and locally very thick HSU in the PM-OV model area that includes all the } \\
\text { volcanic rocks older than the Belted Range Group. Consists of a poorly understood distribution of } \\
\text { volcanic aquifers and confining units. }\end{array}$ \\
\hline $\begin{array}{l}\text { Belted Range confining } \\
\text { unit } \\
\text { (BRCU) }\end{array}$ & $\mathrm{TCU}$ & Tn, Tn4, Tn3 & $\begin{array}{l}\text { Includes all zeolitized tuffs above the welded Tub Spring Tuff (i.e., TSA). Limited to the northern } \\
\text { NTS. }\end{array}$ \\
\hline $\begin{array}{l}\text { Pre-Grouse Canyon Tuff } \\
\text { lava-flow aquifer } \\
\text { (PRETBG) }\end{array}$ & LFA & Tbq, Tuo & $\begin{array}{l}\text { Defined to include all the comendite lava flows emplaced before the Grouse Canyon Tuff but after } \\
\text { the Tub Spring Tuff. Limited to the northern portions of the YF-CM model area. }\end{array}$ \\
\hline $\begin{array}{l}\text { Tub Spring aquifer } \\
\text { (TUBA) }\end{array}$ & LFA & Tub & Comprises only the welded Tub Spring Tuff and is limited to the northeastern NTS. \\
\hline $\begin{array}{l}\text { Pre-Grouse Canyon Tuff } \\
\text { lava-flow aquifer } 1 \\
\text { (PRETBG1) }\end{array}$ & LFA & Tue & $\begin{array}{l}\text { Defined to include all the comendite lava flows emplaced before the Tub Spring Tuff but after the } \\
\text { older Tunnel beds (Ton). Limited to the northern portion of the YF-CM model area. }\end{array}$ \\
\hline
\end{tabular}


Table A-1

Hydrostratigraphic Units of UGTA CAU-Scale Hydrostratigraphic Framework Models (continued)

\begin{tabular}{|c|c|c|c|}
\hline $\begin{array}{l}\text { Hydrostratigraphic Unit } \\
\text { (Symbol) }\end{array}$ & $\begin{array}{c}\text { Dominant } \\
\begin{array}{c}\text { Hydrogeologic } \\
\text { Unit(s) }\end{array}\end{array}$ & $\begin{array}{l}\text { Stratigraphic } \\
\text { Units }\end{array}$ & General Description \\
\hline $\begin{array}{l}\text { Lower tuff confining unit } \\
\text { (LTCU) }\end{array}$ & TCU & $\begin{array}{l}\text { Tmrh, Tp, Th, Tw, } \\
\text { Tc, Tn, Tub, } \\
\text { Ton2, To, Tlt }\end{array}$ & $\begin{array}{l}\text { Generally includes all older zeolitized tuffs in the central and eastern NTS area. Stratigraphically } \\
\text { the LTCU may include all units from the base of the Rainier Mesa Tuff to the top of the Paleozoic } \\
\text { rocks. The strongly argillized older tuffs and paleocolluvium that immediately overlie pre-Tertiary } \\
\text { rocks may also be included. The uppermost zeolitized bedded tuffs overlying the TSA in central } \\
\text { and eastern NTS form a separate HSU (the UTCU). Subdivided into the LTCU, OSBCU, and } \\
\text { ATCU where there is sufficient drill-hole control. }\end{array}$ \\
\hline $\begin{array}{l}\text { Oak Spring Butte } \\
\text { confining unit } \\
\text { (OSBCU) }\end{array}$ & TCU & $\begin{array}{l}\text { Ton2, To, Toy, } \\
\text { Ton1, Tor, Tot }\end{array}$ & $\begin{array}{l}\text { Typically includes all volcanic rocks below the Tub Spring Tuff (Tub) to the top of pervasive } \\
\text { argillization (i.e., ATCU), if present. Where not delineated, the units of the OSBCU are grouped } \\
\text { within the LTCU. }\end{array}$ \\
\hline $\begin{array}{l}\text { Redrock Valley aquifer } \\
\text { (RVA) }\end{array}$ & WTA & Tor, Tot & $\begin{array}{l}\text { Includes only the welded lithofacies of the Redrock Valley Tuff in central and northern NTS. } \\
\text { Where not strongly welded, lumped with the OSBCU or the LTCU. }\end{array}$ \\
\hline $\begin{array}{l}\text { Redrock Valley breccia } \\
\text { confining unit } \\
\text { (RVBCU) }\end{array}$ & TCU/AA & Not defined & $\begin{array}{l}\text { Very limited areal extent; wedge-shaped volume inside the structural margin of the Redrock } \\
\text { Valley caldera. Breccia blocks within an argillic matrix. }\end{array}$ \\
\hline $\begin{array}{l}\text { Lower tuff confining } \\
\text { unit } 1 \text { (LTCU1) }\end{array}$ & TCU & To & $\begin{array}{l}\text { Zeolitic bedded tuffs below the welded Redrock Valley Tuff. Separates overlying RVA from pre- } \\
\text { Tertiary units and/or ATCU. }\end{array}$ \\
\hline $\begin{array}{l}\text { Twin Peaks aquifer } \\
\text { (TPA) }\end{array}$ & WTA & Tot & $\begin{array}{l}\text { Includes only the welded lithofacies of the tuff of Twin Peaks in central and northern NTS. Where } \\
\text { not strongly welded, is lumped with the OSBCU or the LTCU. Defined only for the "No Redrock } \\
\text { Valley Caldera" alternative; otherwise lumped with the RVA. }\end{array}$ \\
\hline $\begin{array}{l}\text { Argillic tuff confining unit } \\
\text { (ATCU) }\end{array}$ & TCU & To, Tlt & $\begin{array}{l}\text { Includes the argillic, lowermost Tertiary volcanic units and paleocolluvium that immediately overlie } \\
\text { the pre-Tertiary rocks. }\end{array}$ \\
\hline $\begin{array}{l}\text { Volcaniclastic confining } \\
\text { unit } \\
\text { (VCU) }\end{array}$ & TCU & Tgp, Tgw & $\begin{array}{l}\text { Older Tertiary-age sedimentary rocks of variable lithologies. Present in the southeastern corner } \\
\text { of the YF-CM model area, but is a significant HSU in the Frenchman Flat model area. Similar to } \\
\text { AA in the YF-CM model, but name retained to correlate with the Frenchman Flat model in the } \\
\text { area of overlap. }\end{array}$ \\
\hline
\end{tabular}


Table A-1

Hydrostratigraphic Units of UGTA CAU-Scale Hydrostratigraphic Framework Models (continued)

\begin{tabular}{|c|c|c|c|}
\hline $\begin{array}{l}\text { Hydrostratigraphic Unit } \\
\text { (Symbol) }\end{array}$ & $\begin{array}{c}\text { Dominant } \\
\text { Hydrogeologic }^{\text {Unit(s) }} \\
\text { Un }^{\text {Unic }} \\
\end{array}$ & $\begin{array}{l}\text { Stratigraphic } \\
\text { Units }\end{array}$ & General Description \\
\hline $\begin{array}{l}\text { Black Mountain } \\
\text { intrusive } \\
\text { confining unit } \\
\text { (BMICU) }\end{array}$ & $\mathrm{IICU}$ & Not defined & \multirow[t]{7}{*}{$\begin{array}{l}\text { Although modeled as single intrusive masses beneath each of the Black Mountain, Ammonia } \\
\text { Tanks, Rainier Mesa, Claim Canyon, and Silent Canyon calderas, and the Calico Hills area, the } \\
\text { actual nature of these units is unknown. They may consist exclusively of igneous intrusive rocks } \\
\text { or older volcanic and pre-Tertiary sedimentary rocks that are intruded to varying degrees by } \\
\text { igneous rocks ranging in composition from granite to basalt. }\end{array}$} \\
\hline $\begin{array}{l}\text { Ammonia Tanks } \\
\text { intrusive } \\
\text { confining unit } \\
\text { (ATICU) }\end{array}$ & $\mathrm{IICU}$ & Not defined & \\
\hline $\begin{array}{l}\text { Rainier Mesa } \\
\text { intrusive } \\
\text { confining unit } \\
\text { (RMICU) }\end{array}$ & $\mathrm{IICU}$ & Not defined & \\
\hline $\begin{array}{l}\text { Claim Canyon } \\
\text { intrusive } \\
\text { confining unit } \\
\text { (CClCU) }\end{array}$ & $\mathrm{IICU}$ & Not defined & \\
\hline $\begin{array}{l}\text { Calico Hills } \\
\text { intrusive } \\
\text { confining unit } \\
\text { (CHICU) }\end{array}$ & $\mathrm{IICU}$ & Not defined & \\
\hline $\begin{array}{l}\text { Silent Canyon } \\
\text { intrusive confining unit } \\
(\mathrm{SCICU})\end{array}$ & $\mathrm{IICU}$ & Not defined & \\
\hline $\begin{array}{c}\text { Redrock Valley intrusive } \\
\text { confining unit } \\
\text { (RVICU) }\end{array}$ & $\mathrm{IICU}$ & Not defined & \\
\hline $\begin{array}{l}\text { Mesozoic granite } \\
\text { confining unit } \\
\text { (MGCU) }\end{array}$ & GCU & $\mathrm{Kg}$ & $\begin{array}{l}\text { Consists of granitic rocks that form the Gold Meadows and Climax stocks in the northern part of } \\
\text { the NTS. }\end{array}$ \\
\hline $\begin{array}{l}\text { Lower clastic confining } \\
\text { unit 1-thrust plate } \\
\text { (LCCU1) }\end{array}$ & $\mathrm{CCU}$ & $\mathrm{Cc}, \mathrm{Cz}, \mathrm{Czw}, \mathrm{Zs}$ & $\begin{array}{l}\text { Late Proterozoic to Early Cambrian siliciclastic rocks that occur within the hanging wall of the } \\
\text { Belted Range thrust fault. }\end{array}$ \\
\hline
\end{tabular}


Table A-1

Hydrostratigraphic Units of UGTA CAU-Scale Hydrostratigraphic Framework Models (continued)

\begin{tabular}{|c|c|c|c|}
\hline $\begin{array}{l}\text { Hydrostratigraphic Unit } \\
\text { (Symbol) }\end{array}$ & $\begin{array}{l}\text { Dominant } \\
\text { Hydrogeologic } \\
\text { Unit(s) }^{\text {a }}\end{array}$ & $\begin{array}{l}\text { Stratigraphic } \\
\text { Units }\end{array}$ & General Description \\
\hline $\begin{array}{l}\text { Lower carbonate } \\
\text { aquifer- } \\
\text { thrust plate } \\
\text { (LCA3) }\end{array}$ & CA & Dg through Cc & $\begin{array}{l}\text { Cambrian through Devonian, mostly carbonate, rocks that occur in the hanging wall of the Belted } \\
\text { Range and CP thrust faults. Typically separated from correlative rocks within LCA by intervening } \\
\text { younger rocks such as those composing the UCCU. }\end{array}$ \\
\hline $\begin{array}{l}\text { Upper clastic confining } \\
\text { unit-thrust plate } \\
\text { (UCCU1) }\end{array}$ & $\mathrm{CCU}$ & PMc, MDe & $\begin{array}{l}\text { Occurs as a thin imbricate thrust sheet of Mississippian CCU associated with the Belted Range } \\
\text { thrust fault. Defined only for an alternative in the RM-SM HFM. }\end{array}$ \\
\hline $\begin{array}{l}\text { Lower carbonate } \\
\text { aquifer-thrust plate-1 } \\
\quad(\text { LCA3-1) }\end{array}$ & CA & Dg through Cc & $\begin{array}{l}\text { Occurs as a thin imbricate thrust sheet of CA associated with the Belted Range thrust fault. } \\
\text { Defined only for an alternative in the RM-SM HFM. }\end{array}$ \\
\hline $\begin{array}{l}\text { Lower clastic confining } \\
\text { unit 2-thrust plate } \\
\text { (LCCU2) }\end{array}$ & $\mathrm{CCU}$ & $\begin{array}{l}\text { Lower Cc, Cz, } \\
\text { CZw, Zs, Zj }\end{array}$ & $\begin{array}{l}\text { Late Proterozoic to early Cambrian siliciclastic rocks that occur within the hanging wall of the CP } \\
\text { thrust fault. }\end{array}$ \\
\hline $\begin{array}{l}\text { Upper carbonate aquifer } \\
\text { (UCA) }\end{array}$ & CA & PPt & $\begin{array}{l}\text { Includes the Tippipah Limestone, which stratigraphically overlies the Chainman Shale at Syncline } \\
\text { Ridge. }\end{array}$ \\
\hline $\begin{array}{l}\text { Upper clastic } \\
\text { confining unit } \\
\quad(\text { UCCU) }\end{array}$ & $\mathrm{CCU}$ & PMc, MDe & $\begin{array}{l}\text { As much as 2,745 } \mathrm{m}(9,000 \mathrm{ft}) \text { thick. Typically forms footwalls of Mesozoic thrust faults in NTS } \\
\text { region. Limited areal extent (western Yucca Flat and portions of CP Basin). }\end{array}$ \\
\hline $\begin{array}{l}\text { Lower carbonate aquifer } \\
\text { (LCA) }\end{array}$ & CA & Dg through Cc & $\begin{array}{l}\text { Cambrian through Devonian, mostly limestone and dolomite. Important regional aquifer } \\
\text { underlying most of southern Nevada. }\end{array}$ \\
\hline $\begin{array}{l}\text { Lower clastic } \\
\text { confining unit } \\
\quad(\text { LCCU })\end{array}$ & $\mathrm{CCU}$ & $\begin{array}{c}\mathrm{Cc}, \mathrm{Cz}, \mathrm{Czw}, \mathrm{Zs}, \\
\mathrm{Zj}\end{array}$ & $\begin{array}{l}\text { Late Proterozoic through Early Cambrian siliciclastic rocks. Significant regional confining unit. } \\
\text { Composite thickness about 2,870 m (9,400 ft). May present barrier to deep regional groundwater } \\
\text { flow where structurally high (e.g., northeastern Yucca Flat). }\end{array}$ \\
\hline
\end{tabular}

a See Table 3-1 for definitions of HGUs.

b See Plate 1 for definitions of stratigraphic unit map symbols. 
This page intentionally left blank.

A-10 


\section{APPENDIX B}

\section{Examples of HSU Delineation in UGTA Wells}





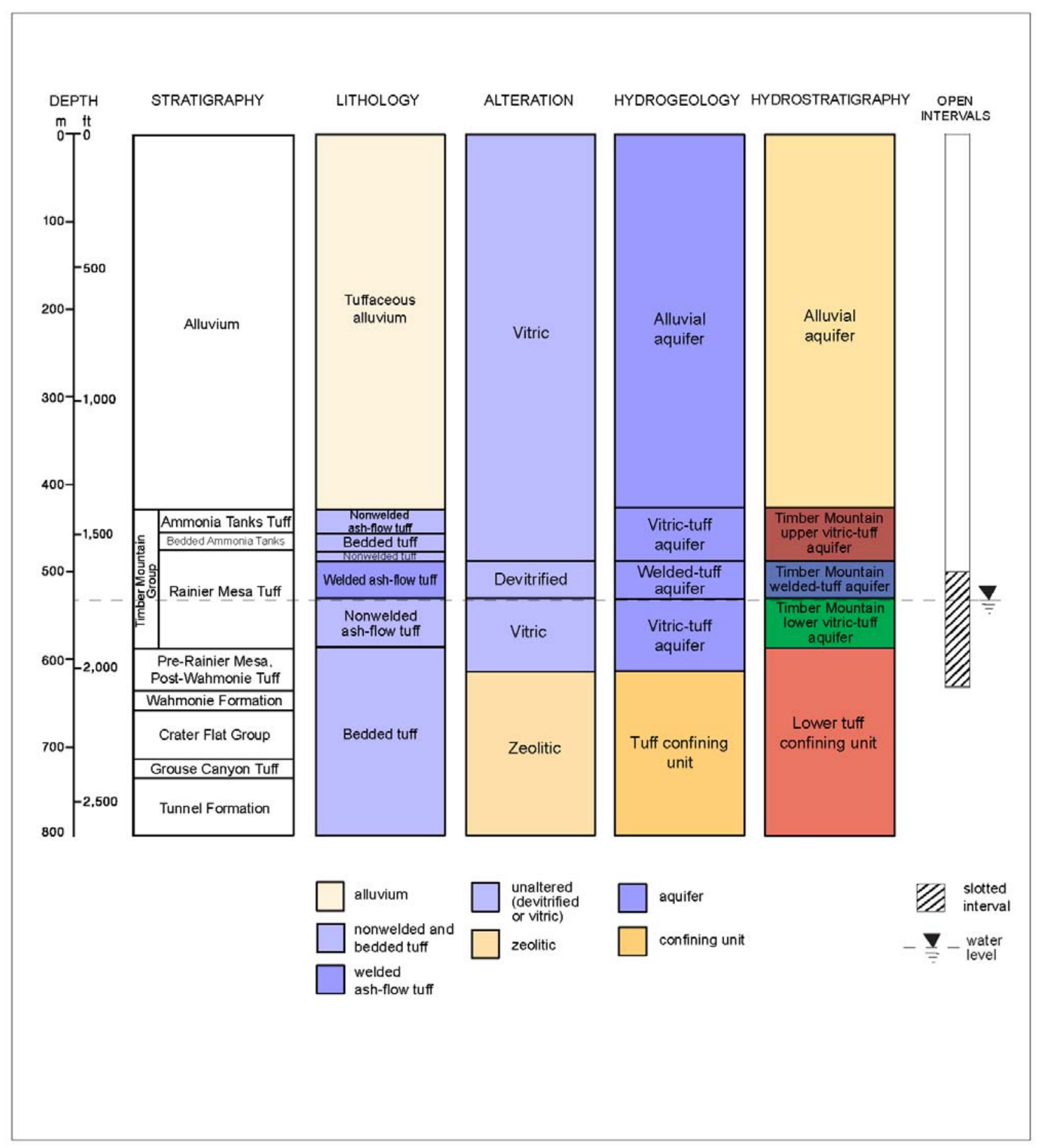

Figure B-1

Graphical Presentation Showing Stratigraphy, Lithology, Alteration, and Hydrogeologic Units for UGTA Well ER-2-1

Modified from NNSA/NSO, 2004h 


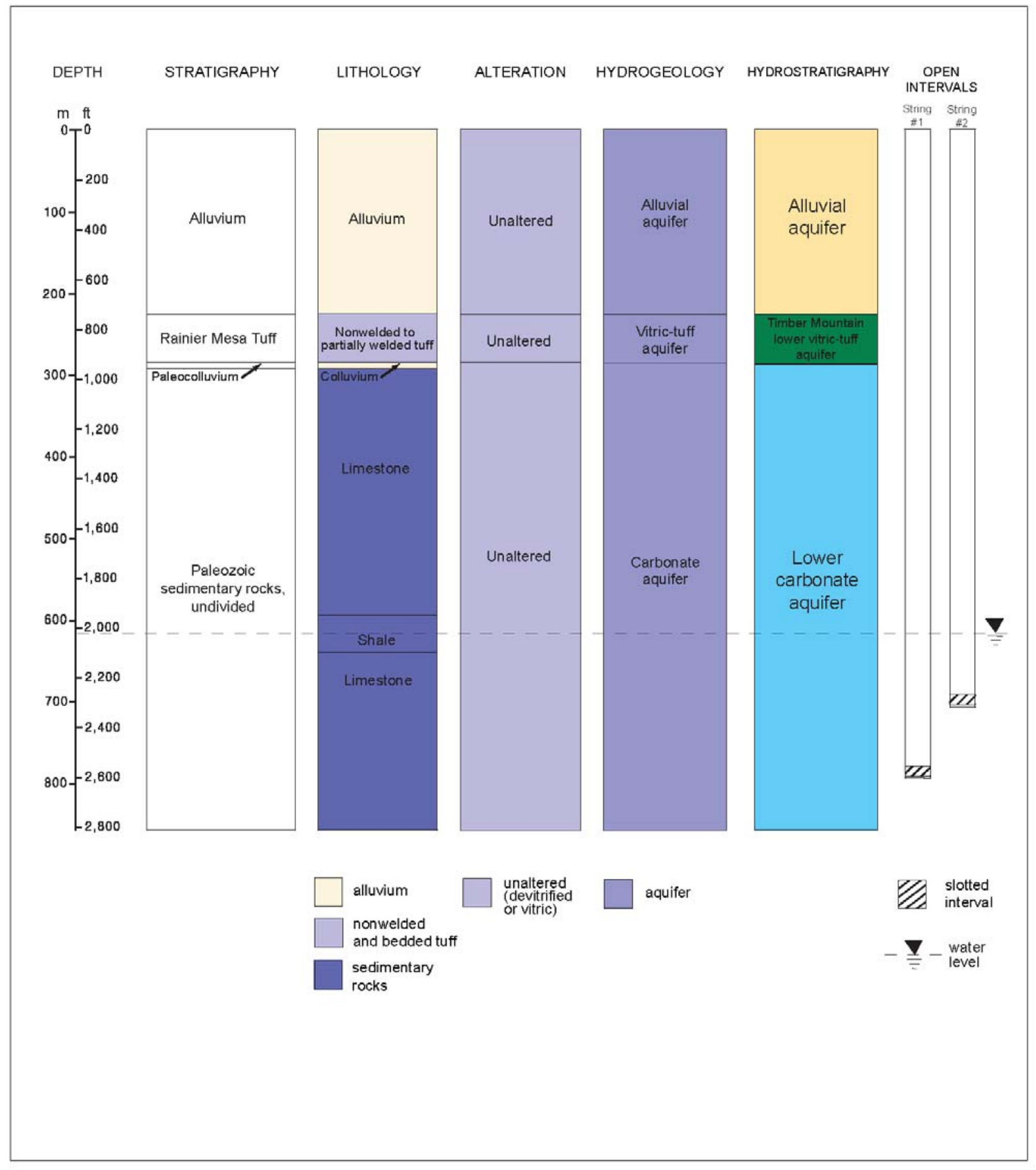

Figure B-2

Graphical Presentation Showing Stratigraphy, Lithology, Alteration, and Hydrogeologic Units for UGTA Well ER-3-1

(Data from DOE/NV, 1995a) 


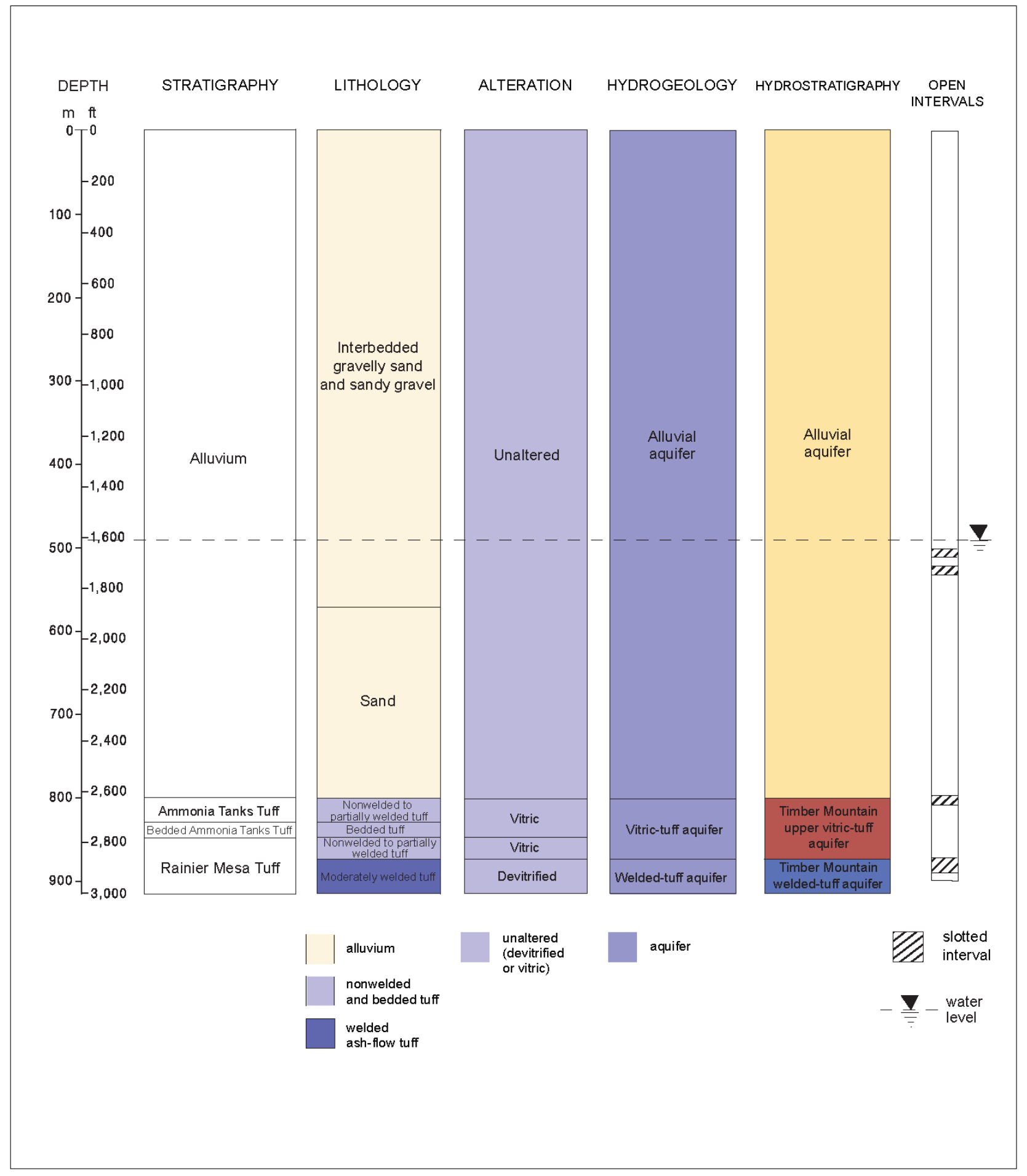

Figure B-3

Graphical Presentation Showing Stratigraphy, Lithology, Alteration, and Hydrogeologic Units for UGTA Well ER-3-2

(Data from DOE/NV, 1995b) 


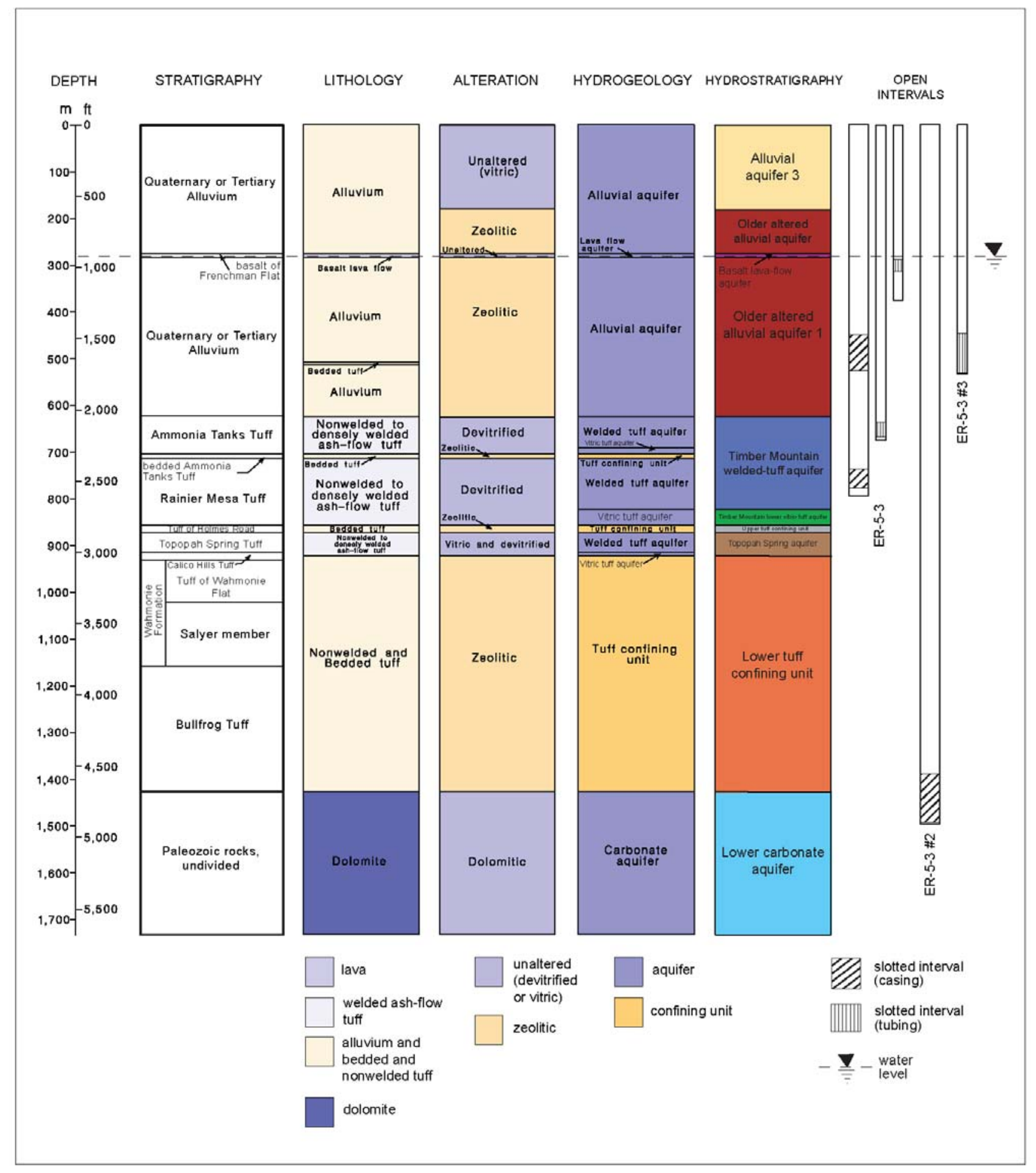

Figure B-4

Graphical Presentation Showing Stratigraphy, Lithology, Alteration, and Hydrogeologic Units for Well Cluster ER-5-3

(Modified from NNSA/NSO, 2005a) 


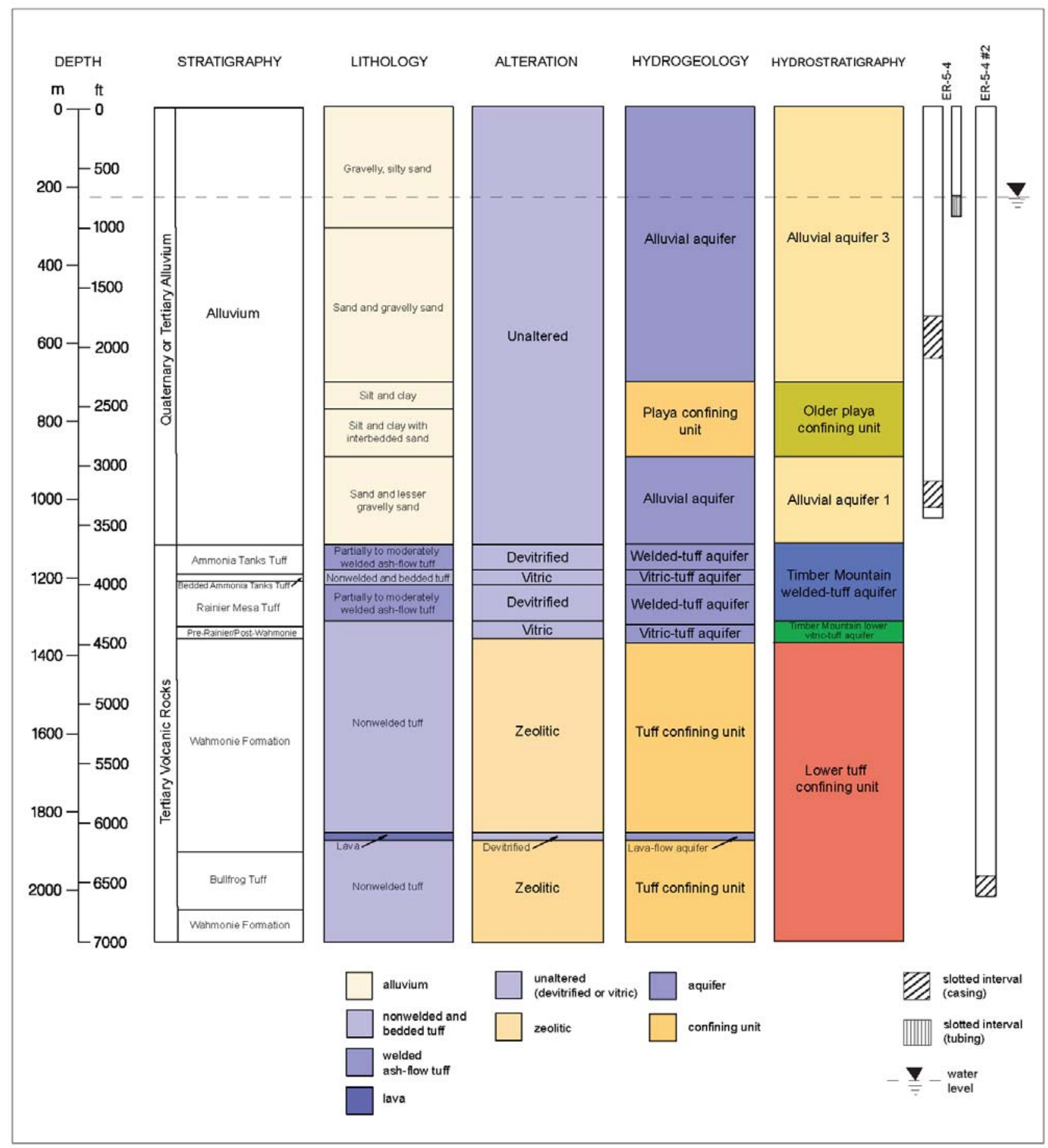

Figure B-5

Graphical Presentation Showing Stratigraphy, Lithology, Alteration, and Hydrogeologic Units for UGTA Well Cluster ER-5-4

(Modified from NNSA/NSO, 2005b) 


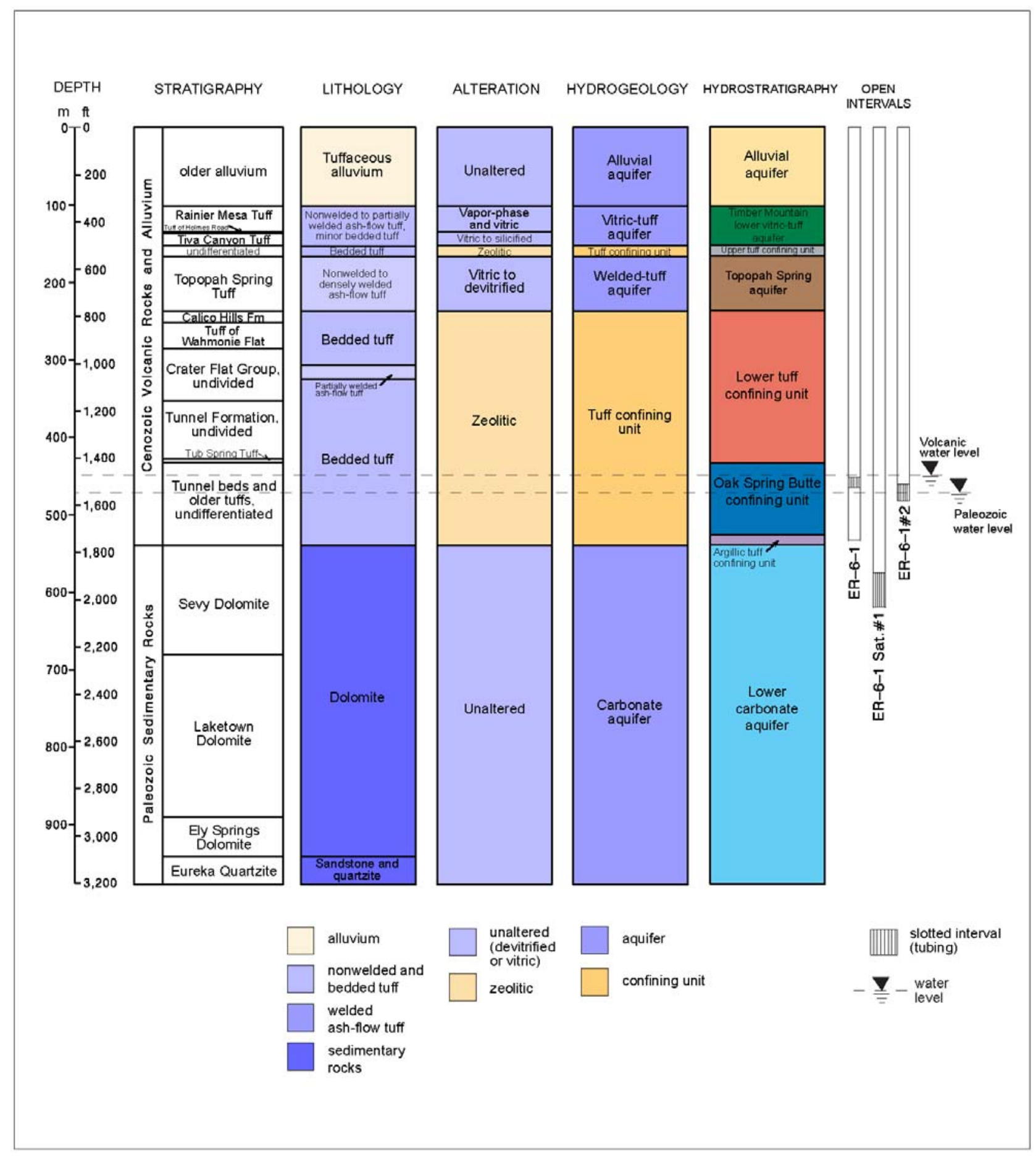

Figure B-6

Graphical Presentation Showing Stratigraphy, Lithology, Alteration, and Hydrogeologic Units for UGTA Well Cluster ER-6-1

(Modified from NNSA/NSO, 2004f) 


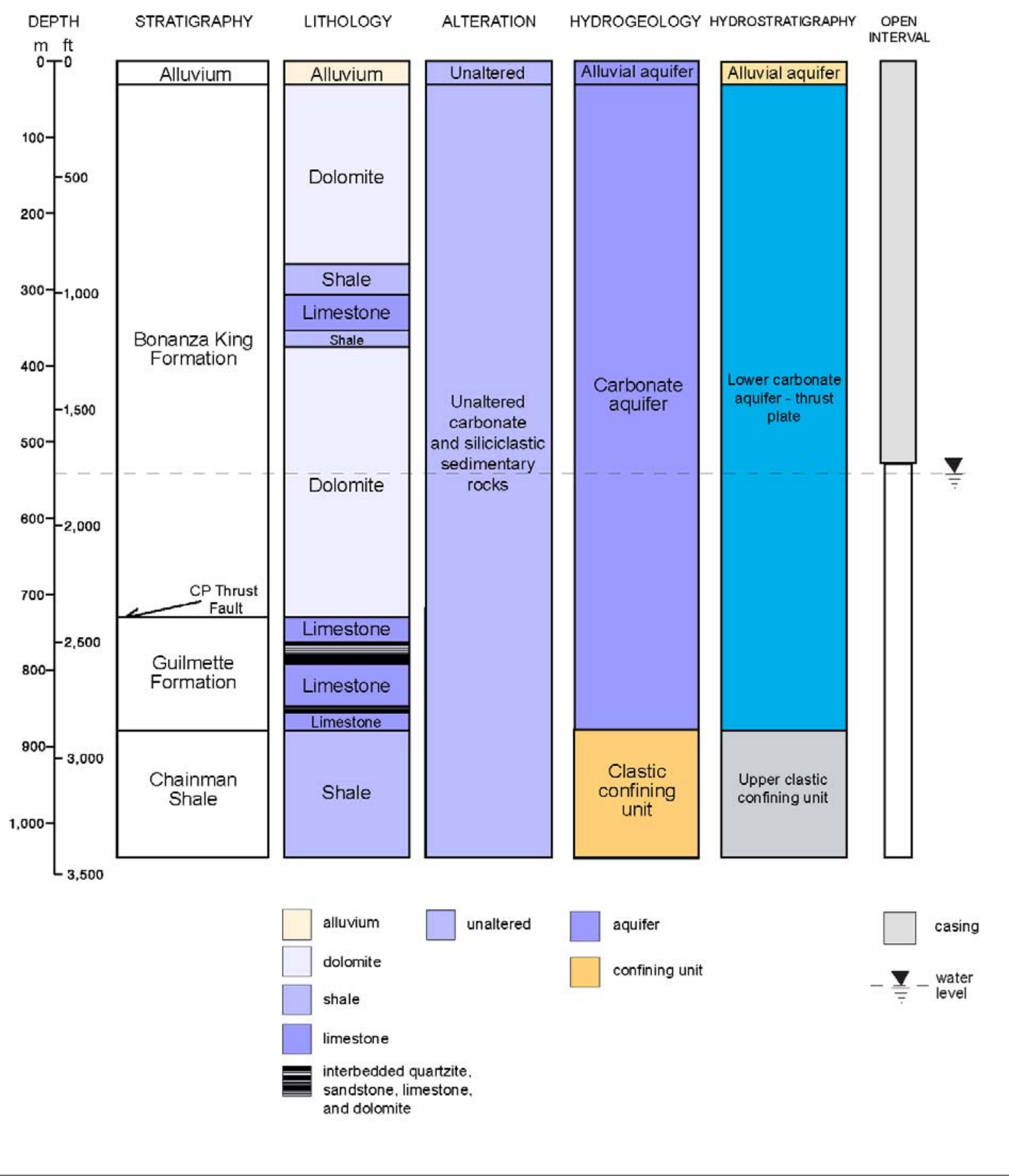

Figure B-7

Graphical Presentation Showing Stratigraphy, Lithology, Alteration, and Hydrogeologic Units for UGTA Well ER-6-2

(Modified from NNSA/NSO, 2008) 


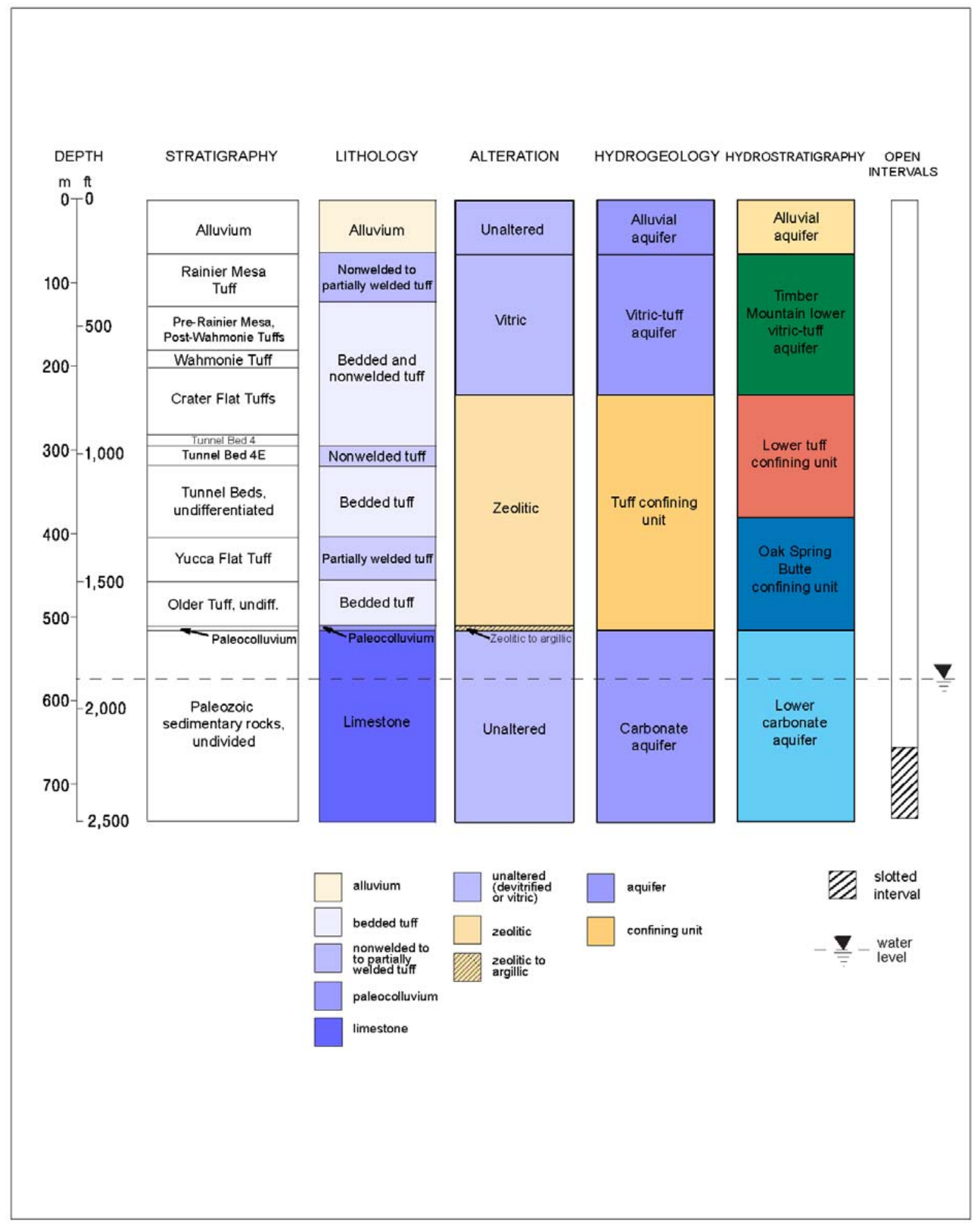

Figure B-8

Graphical Presentation Showing Stratigraphy, Lithology, Alteration, and Hydrogeologic Units for UGTA Well ER-7-1

(Modified from NNSA/NSO, 2004g) 


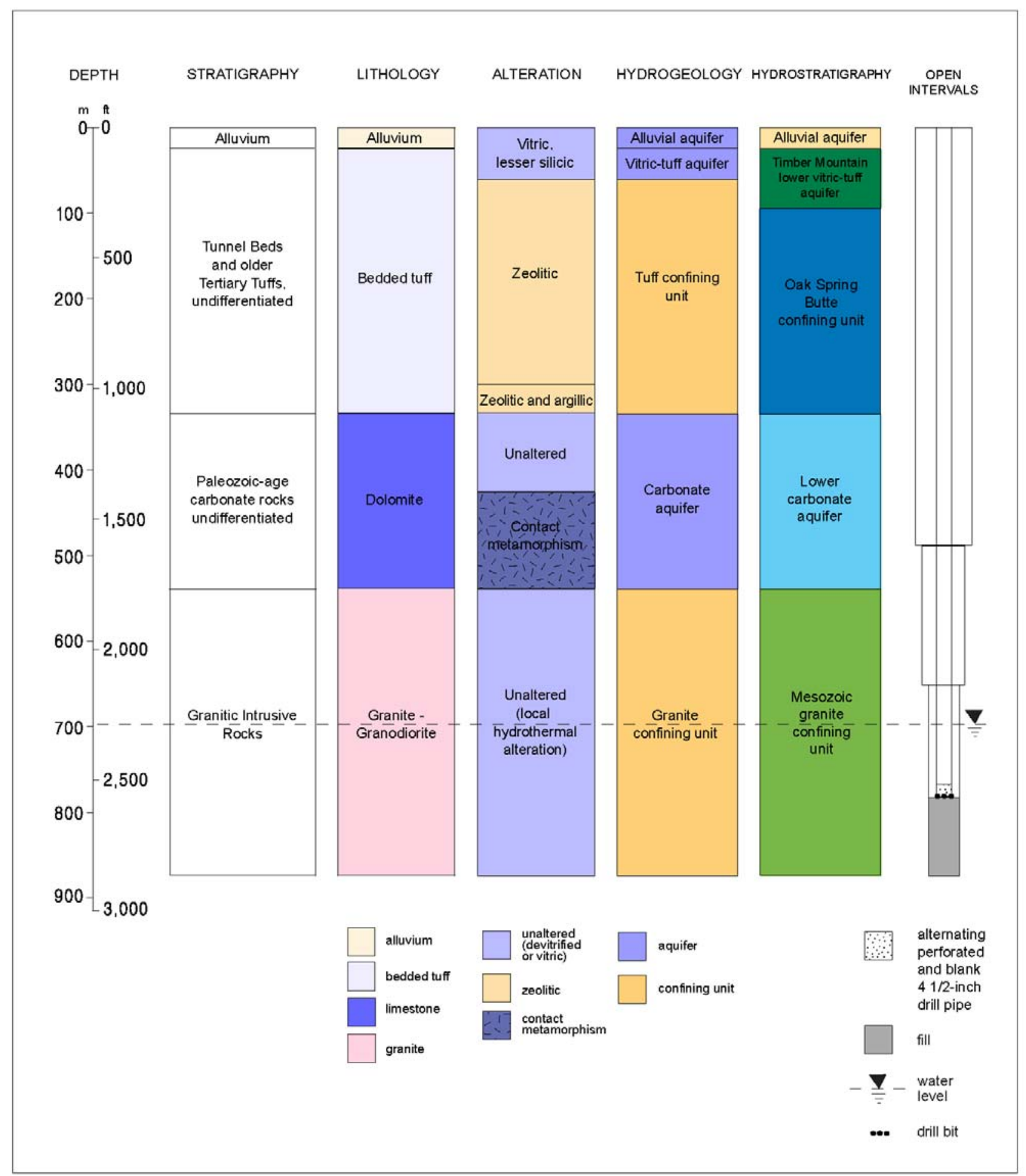

Figure B-9

Graphical Presentation Showing Stratigraphy, Lithology, Alteration, and Hydrogeologic Units for UGTA Well ER-8-1

(Modified from NNSA/NSO, 2004d) 


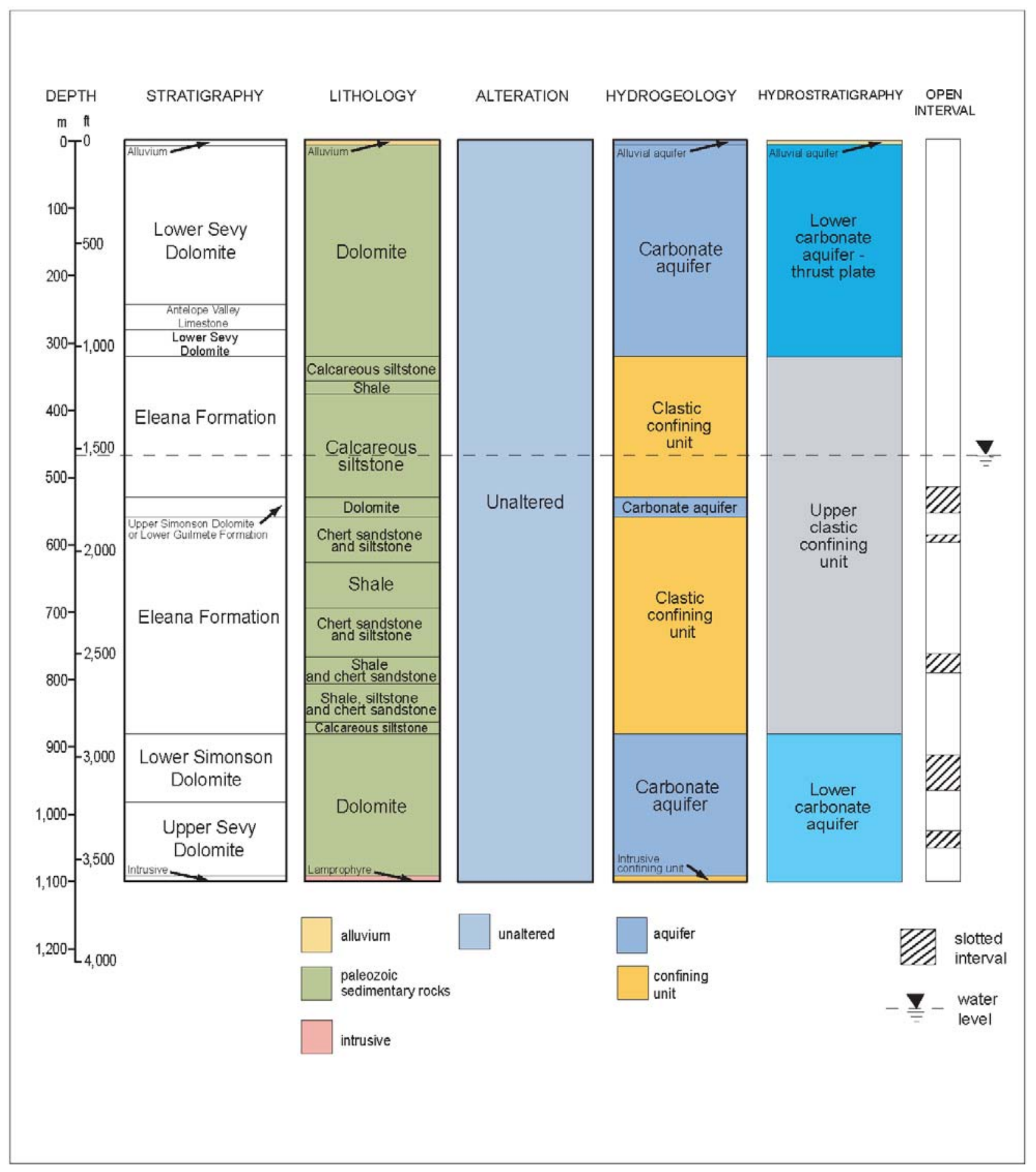

Figure B-10

Graphical Presentation Showing Stratigraphy, Lithology, Alteration, and Hydrogeologic Units for UGTA Well ER-12-1

(Data from Russell et al., 1996) 


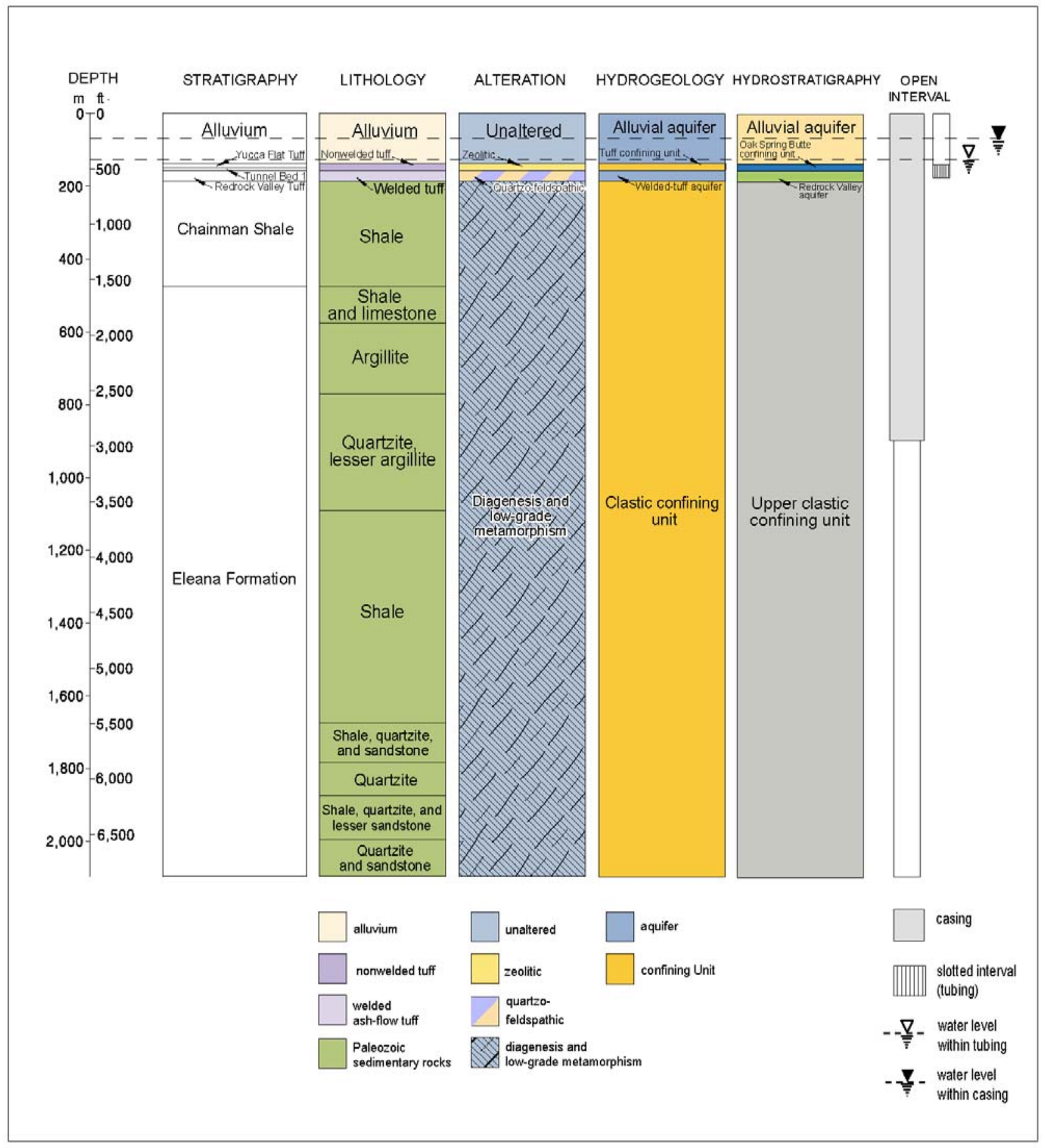

Figure B-11

Graphical Presentation Showing Stratigraphy, Lithology, Alteration, and Hydrogeologic Units for UGTA Well ER-12-2

(Modified from NNSA/NSO, 2004e) 


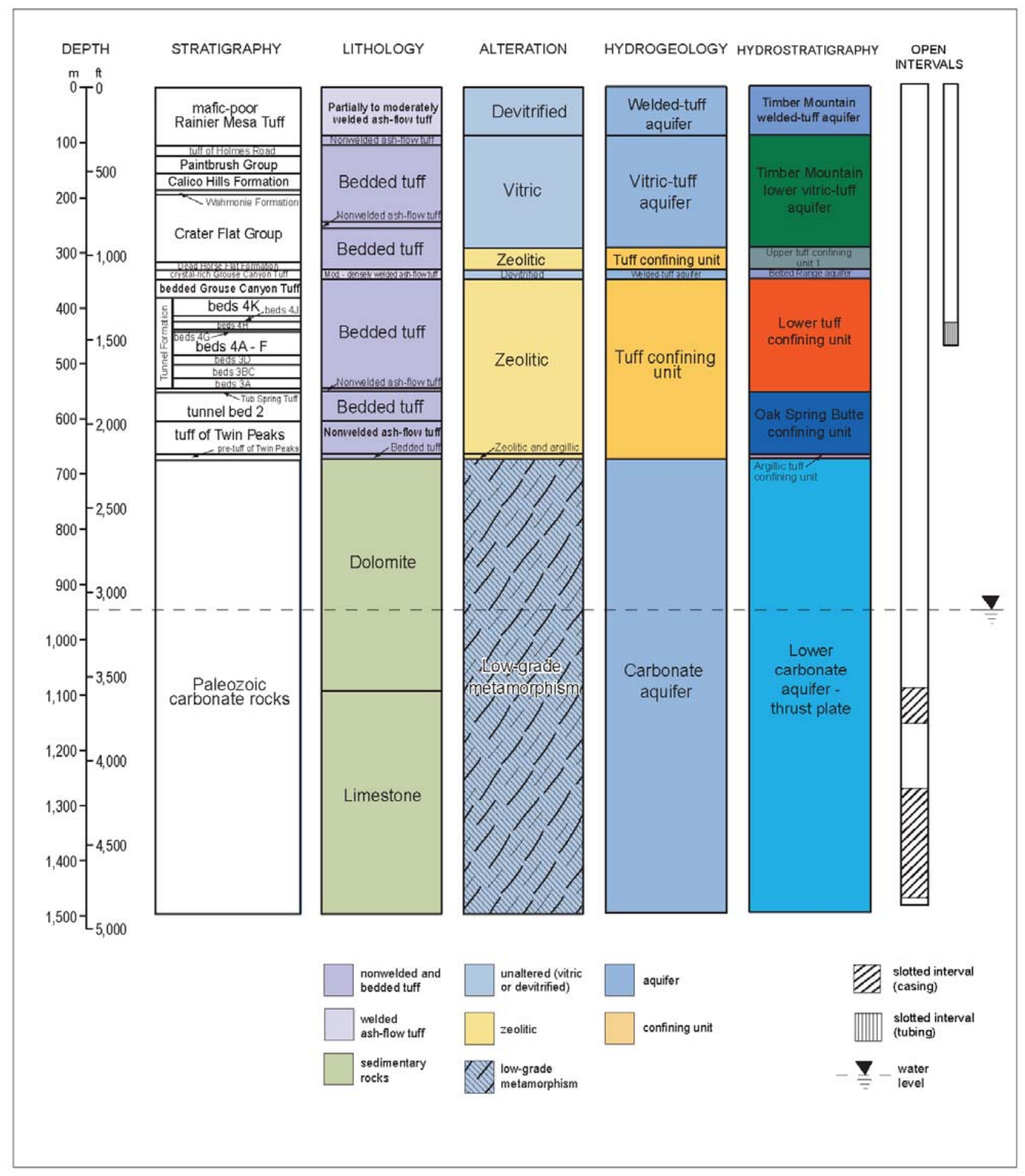

Figure B-12

Graphical Presentation Showing Stratigraphy, Lithology, Alteration, and Hydrogeologic Units for UGTA Well ER-12-3

(Modified from NNSA/NSO, 2006a) 


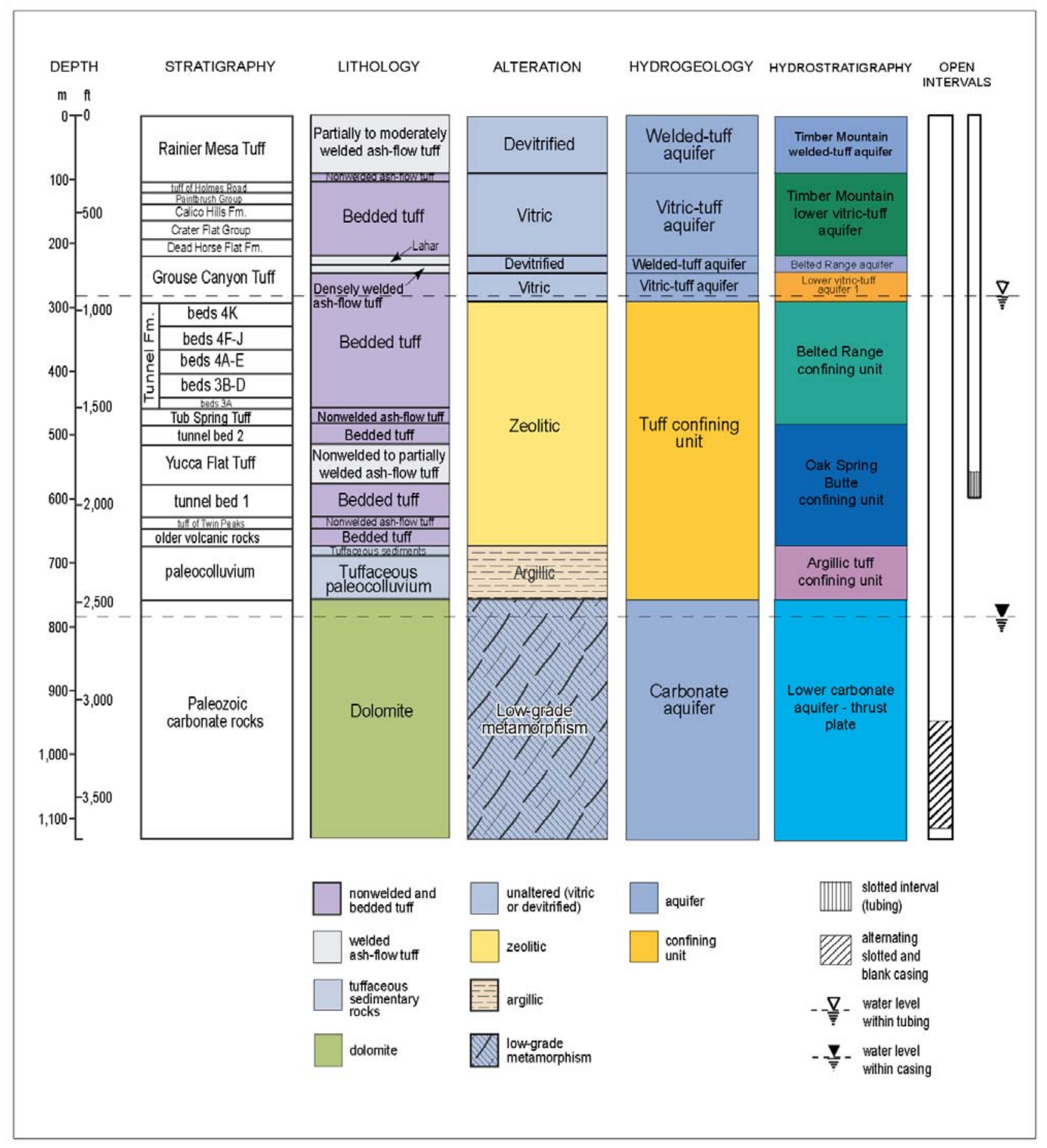

Figure B-13

Graphical Presentation Showing Stratigraphy, Lithology, Alteration, and Hydrogeologic Units for UGTA Well ER-12-4

(Modified from NNSA/NSO, 2006b) 


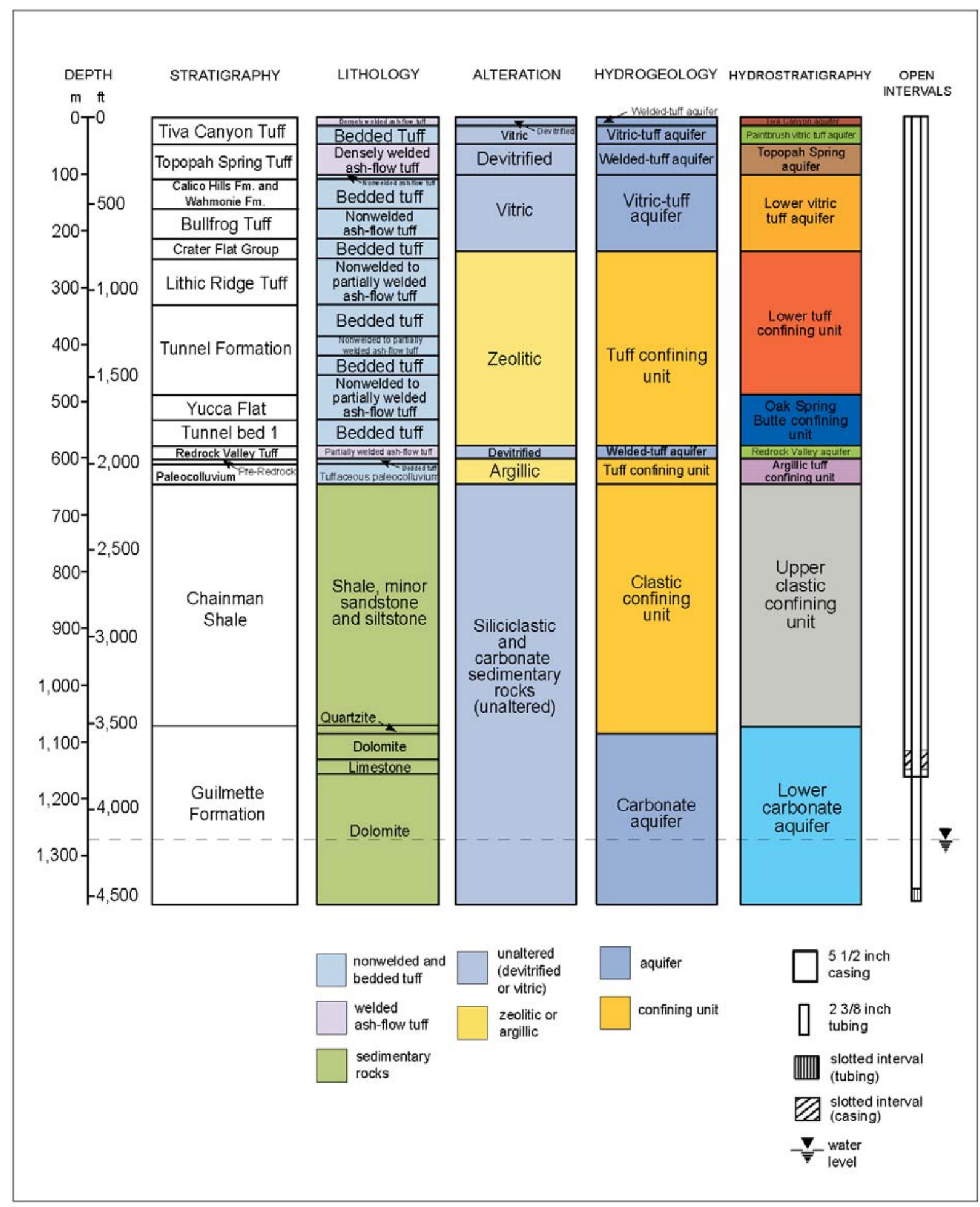

Figure B-14

Graphical Presentation Showing Stratigraphy, Lithology, Alteration, and Hydrogeologic Units for UGTA Well ER-16-1

(Modified from NNSA/NSO, 2006c) 


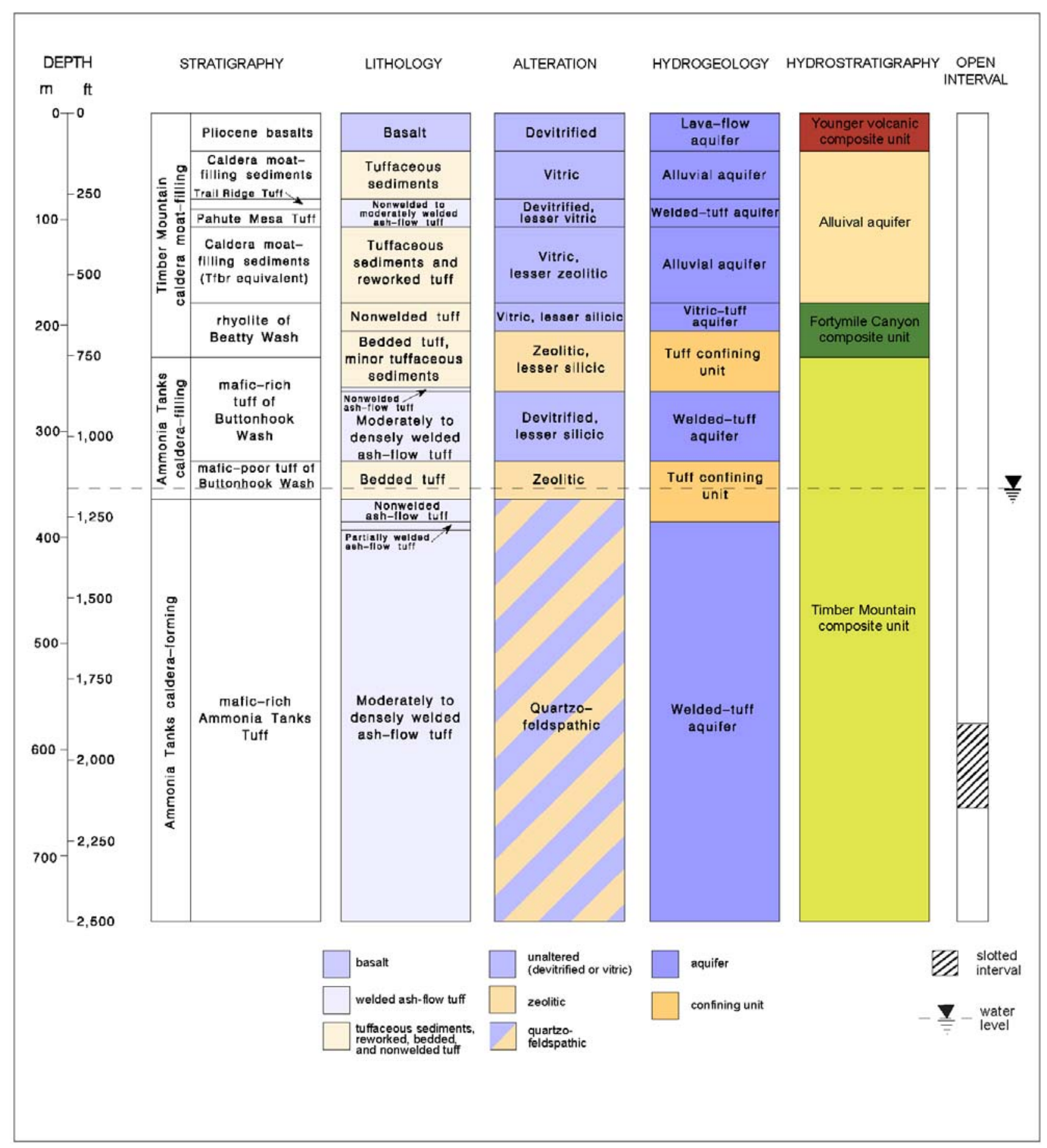

Figure B-15

Graphical Presentation Showing Stratigraphy, Lithology, Alteration, and Hydrogeologic Units for UGTA Well ER-18-2

(Modified from NNSA/NSO, 2003) 


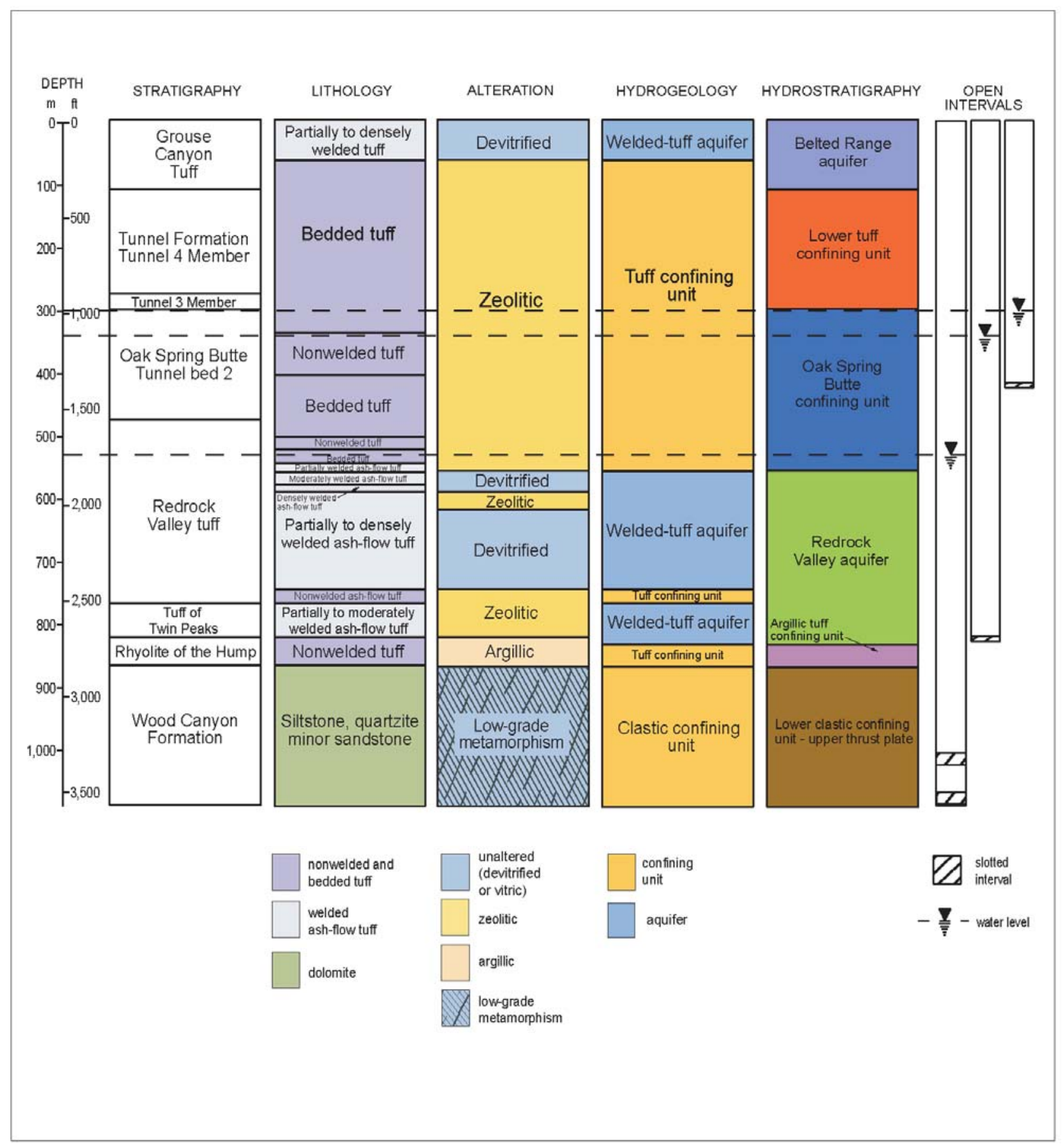

Figure B-16

Graphical Presentation Showing Stratigraphy, Lithology, Alteration, and Hydrogeologic Units for UGTA Well ER-19-1

(Data from DOE/NV, 1995c) 


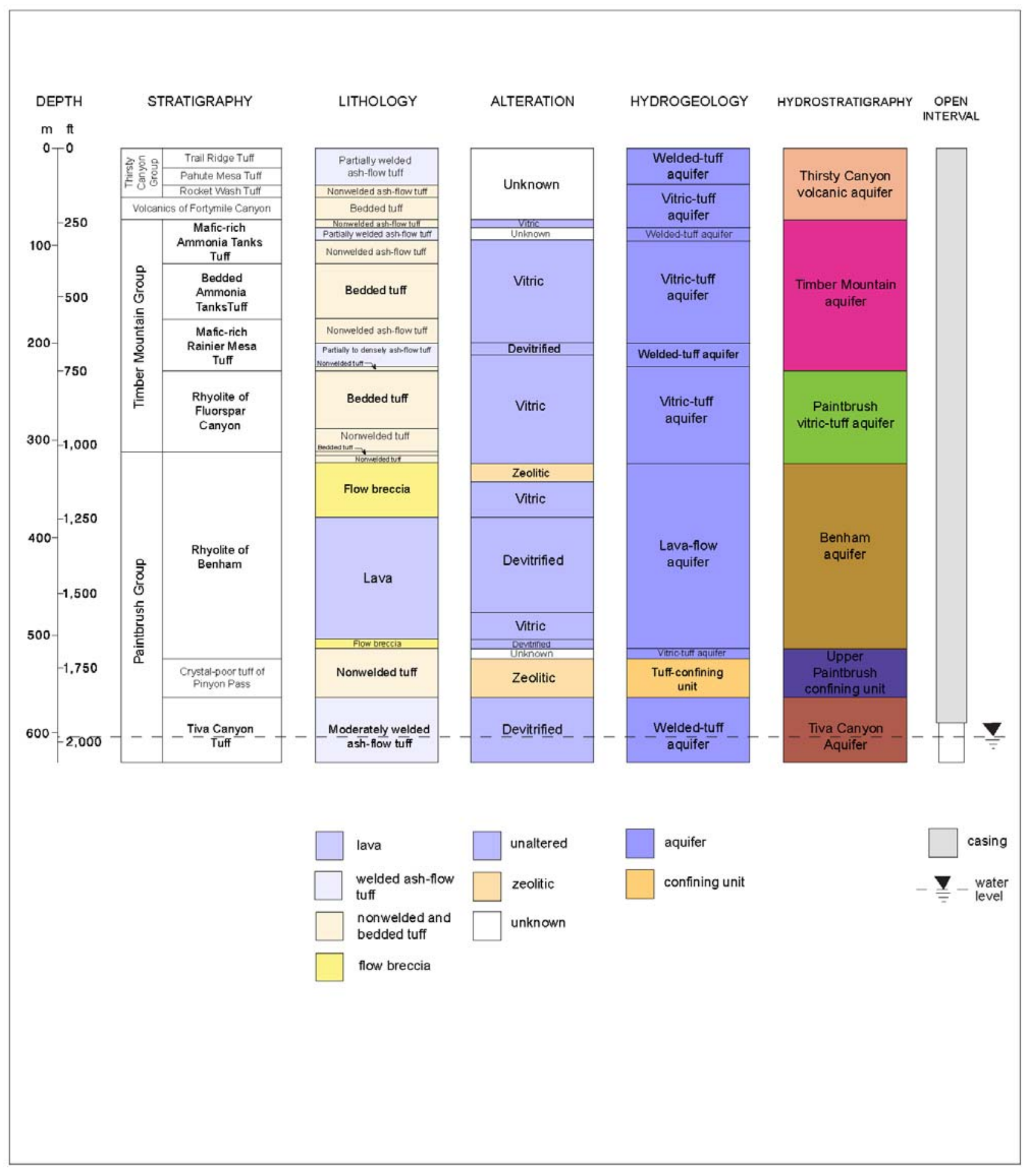

Figure B-17

Graphical Presentation Showing Stratigraphy, Lithology, Alteration, and Hydrogeologic Units for UGTA Well ER-20-1

(Data from BN, 2002) 


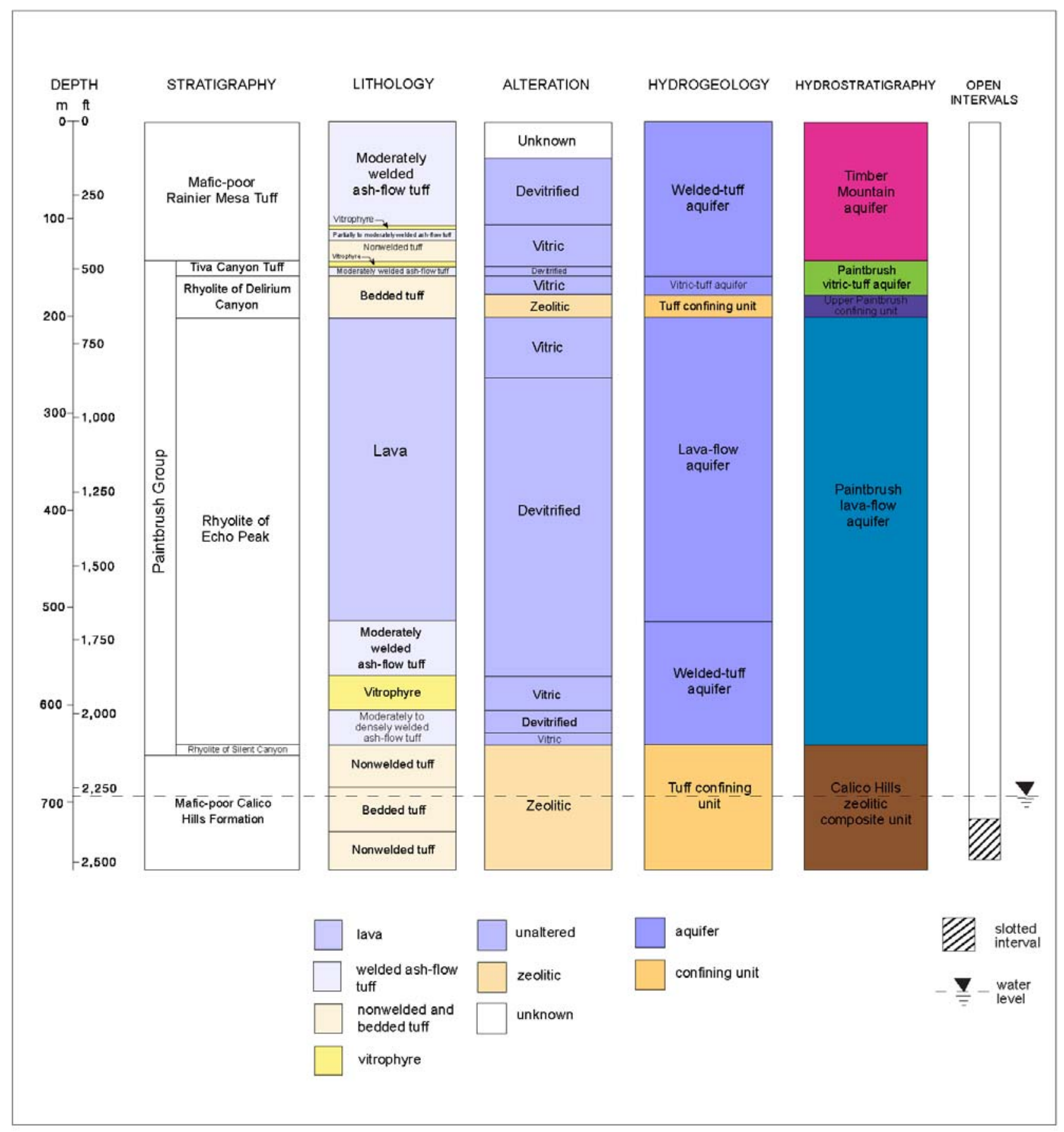

Figure B-18

Graphical Presentation Showing Stratigraphy, Lithology, Alteration, and Hydrogeologic Units for UGTA Well ER-20-2 Sat \#1

(Data from BN, 2002) 


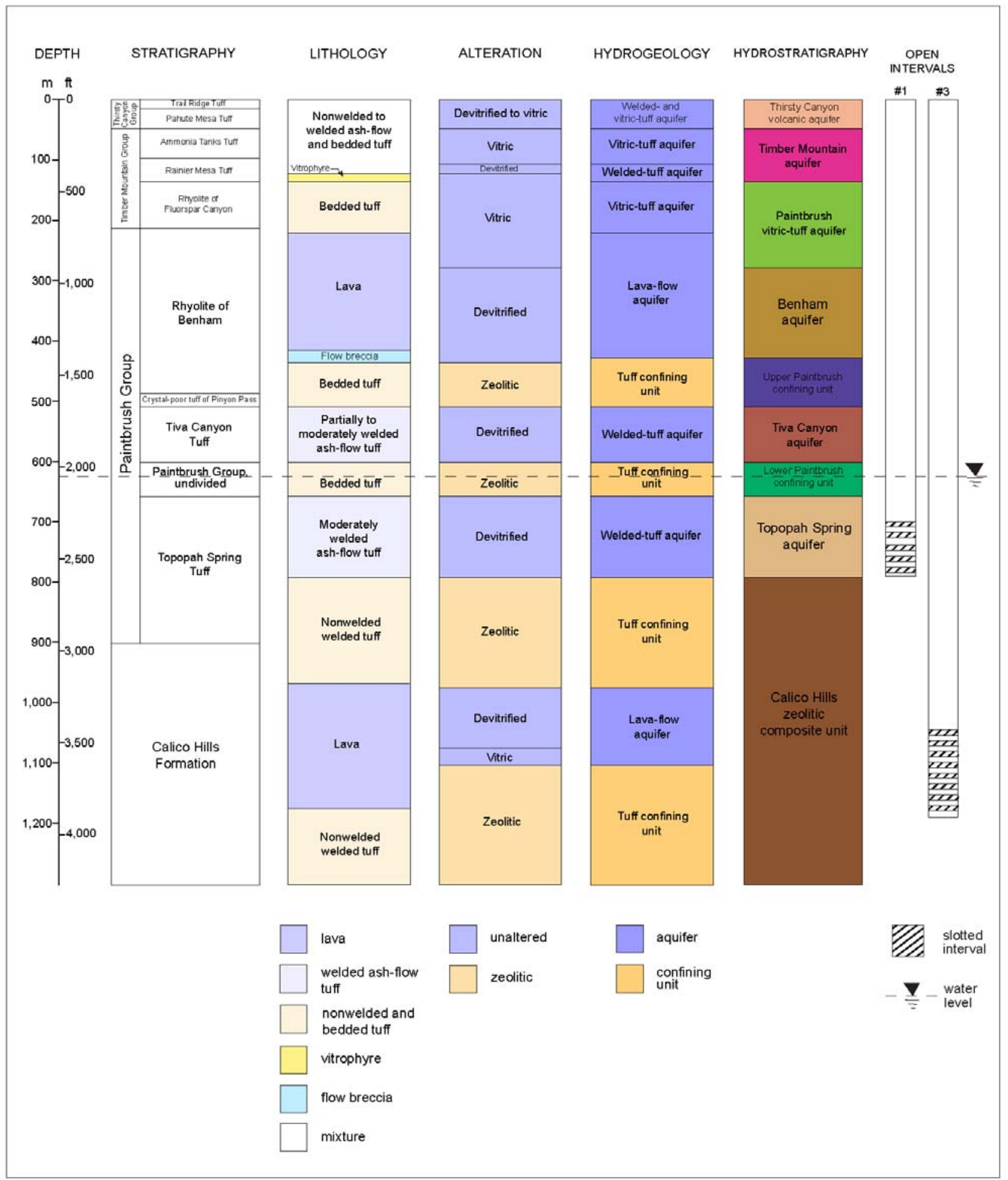

Figure B-19

Graphical Presentation Showing Stratigraphy, Lithology, Alteration, and Hydrogeologic Units for UGTA Well ER-20-5

(Data from DOE/NV, 1997) 


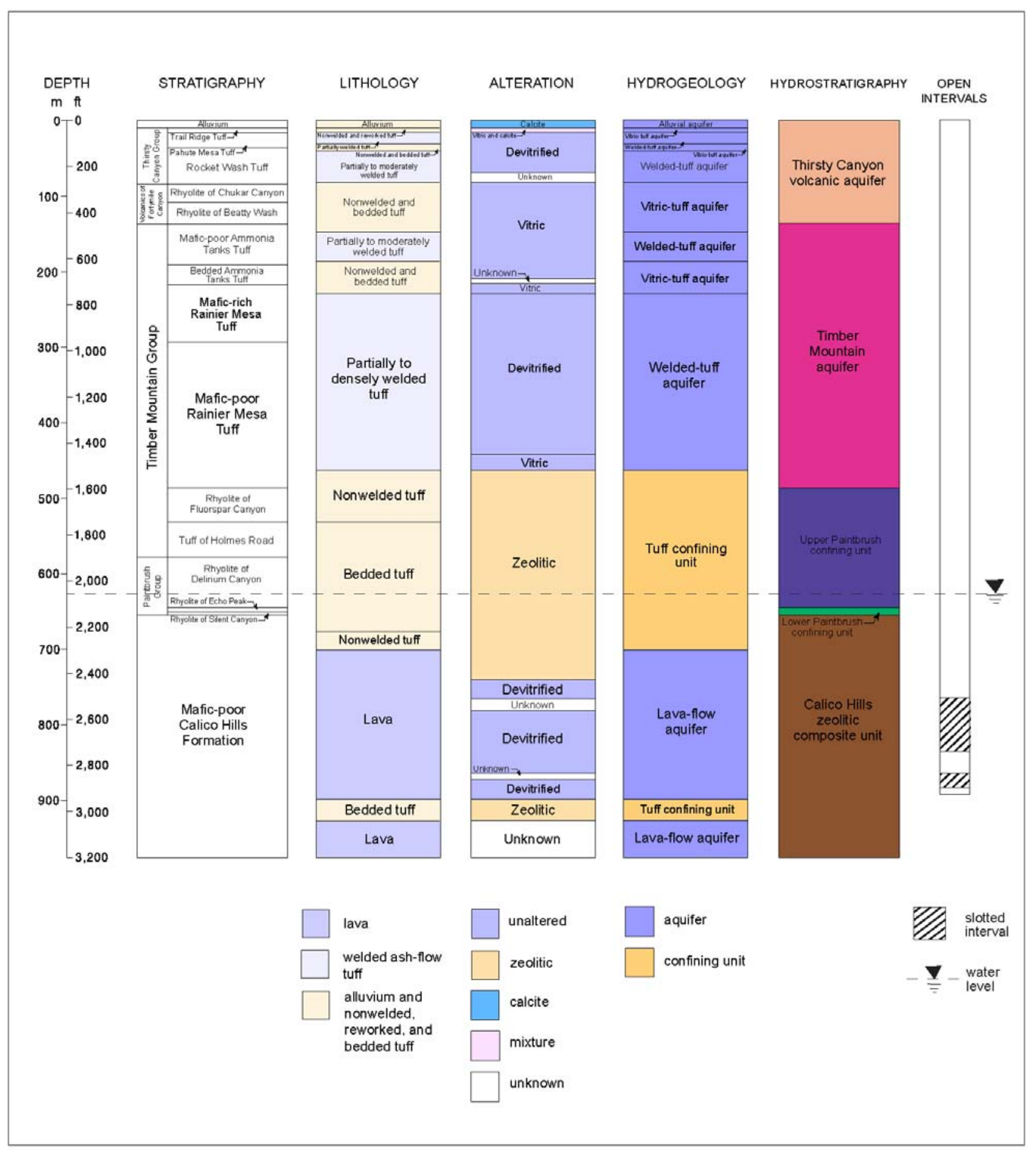

Figure B-20

Graphical Presentation Showing Stratigraphy, Lithology, Alteration, and Hydrogeologic Units for UGTA Well ER-20-6 \#1

(Data from DOE/NV, 1998) 


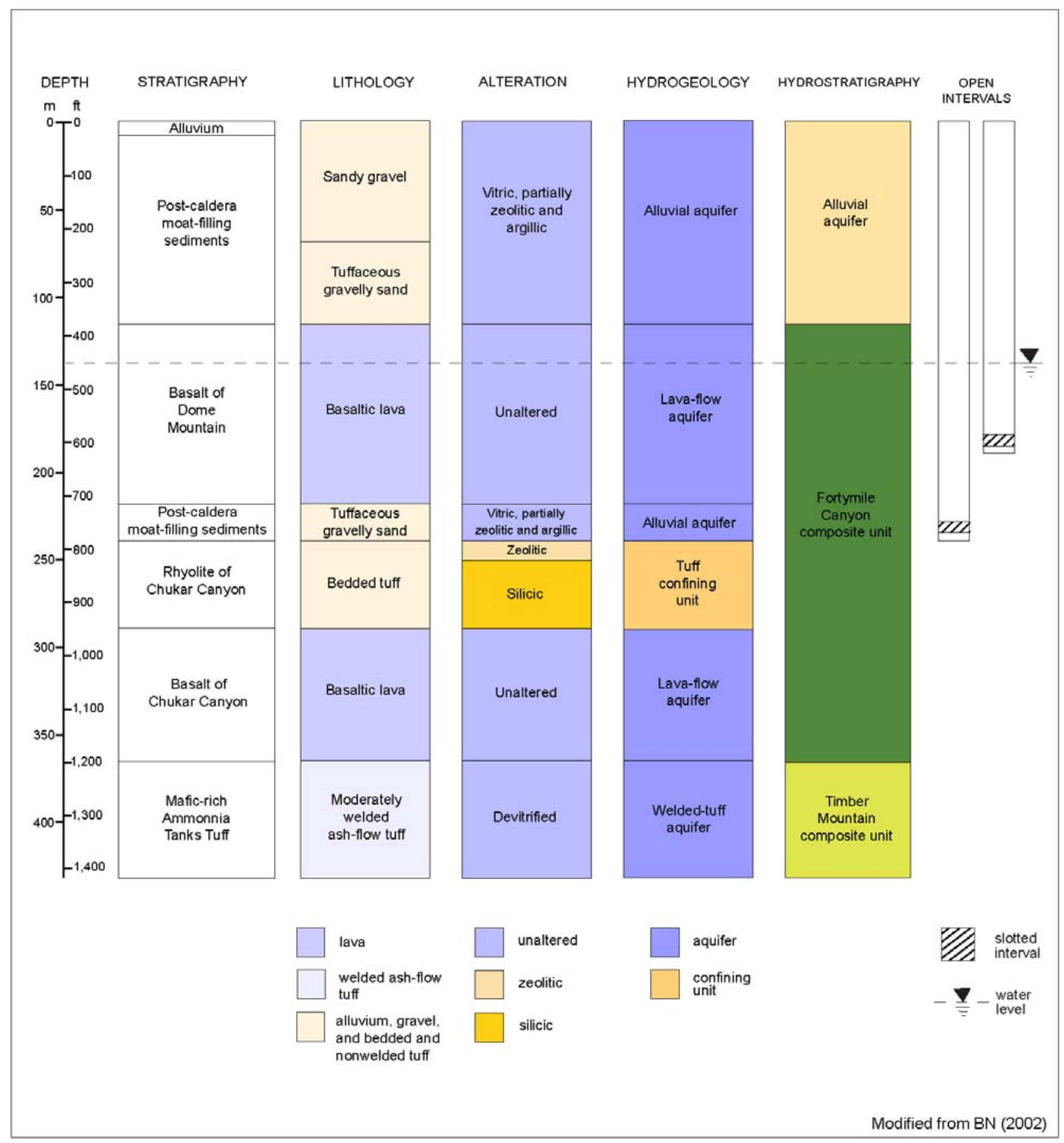

Figure B-21

Graphical Presentation Showing Stratigraphy, Lithology, Alteration, and Hydrogeologic Units for UGTA Well ER-30-1

(Data from DOE/NV, 1995d) 


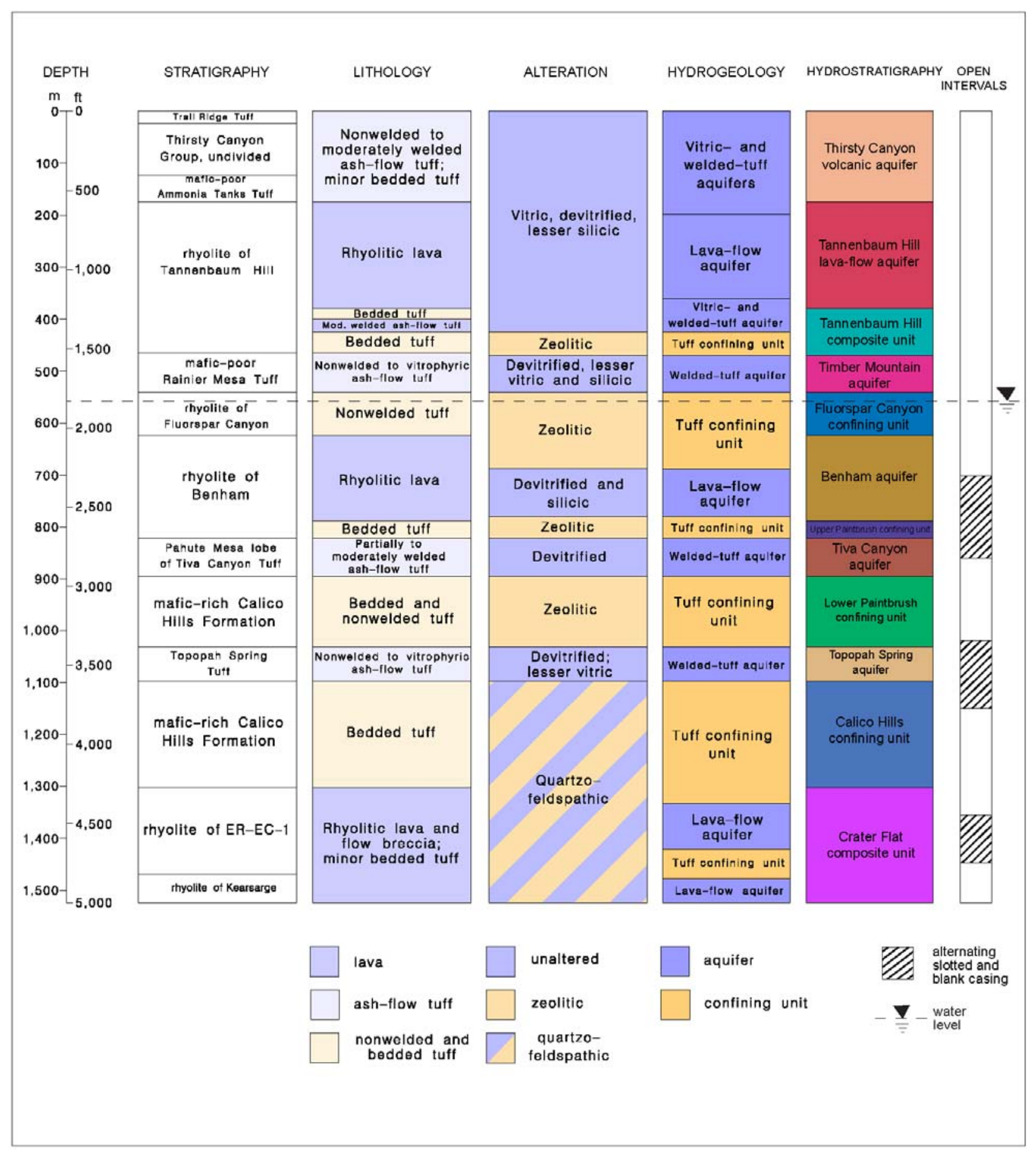

Figure B-22

Graphical Presentation Showing Stratigraphy, Lithology, Alteration, and Hydrogeologic Units for UGTA Well ER-EC-1

(Modified from DOE/NV, 2000b) 


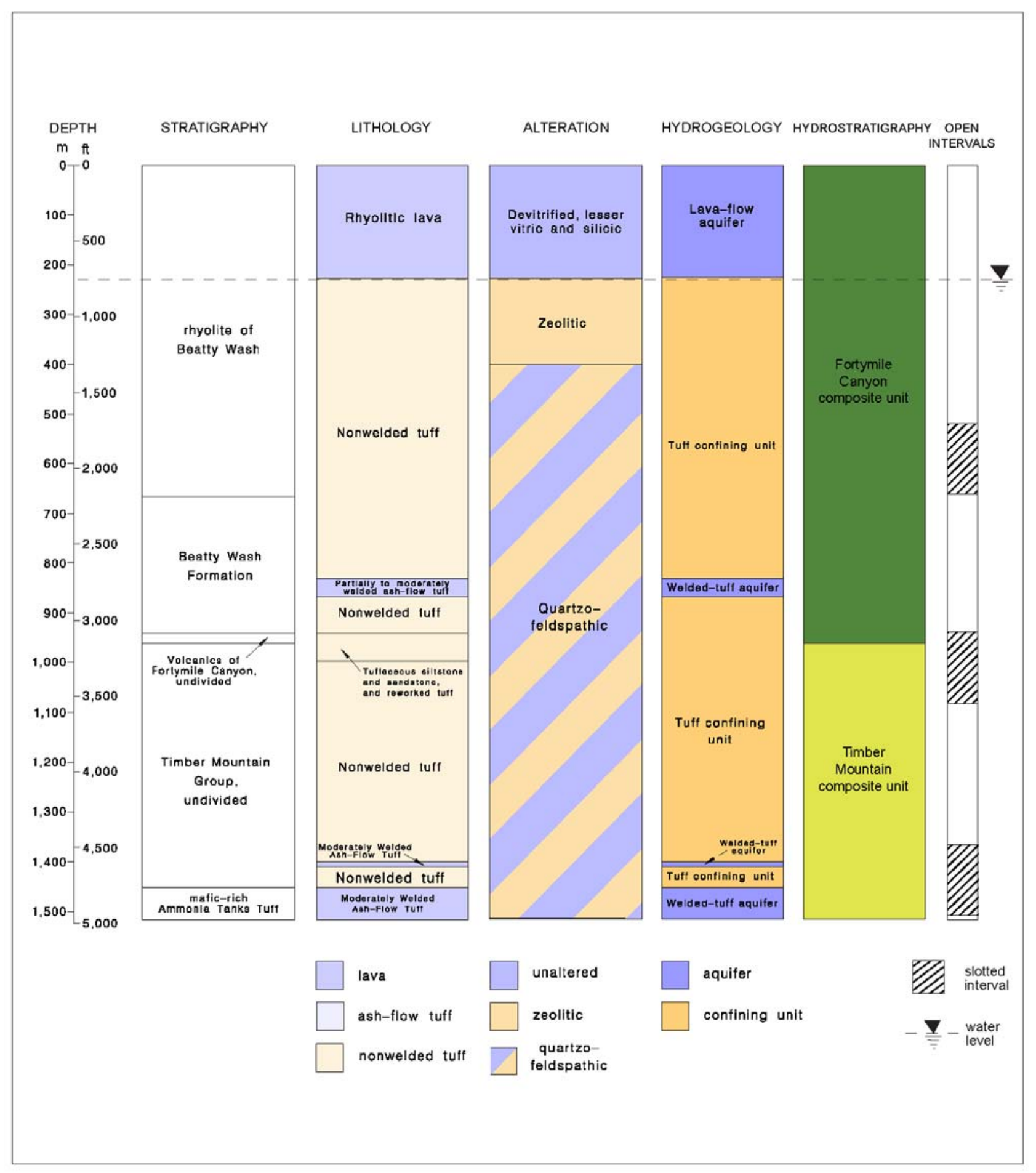

Figure B-23

Graphical Presentation Showing Stratigraphy, Lithology, Alteration, and Hydrogeologic Units for UGTA Well ER-EC-2A

(Modified from DOE/NV, 2002) 


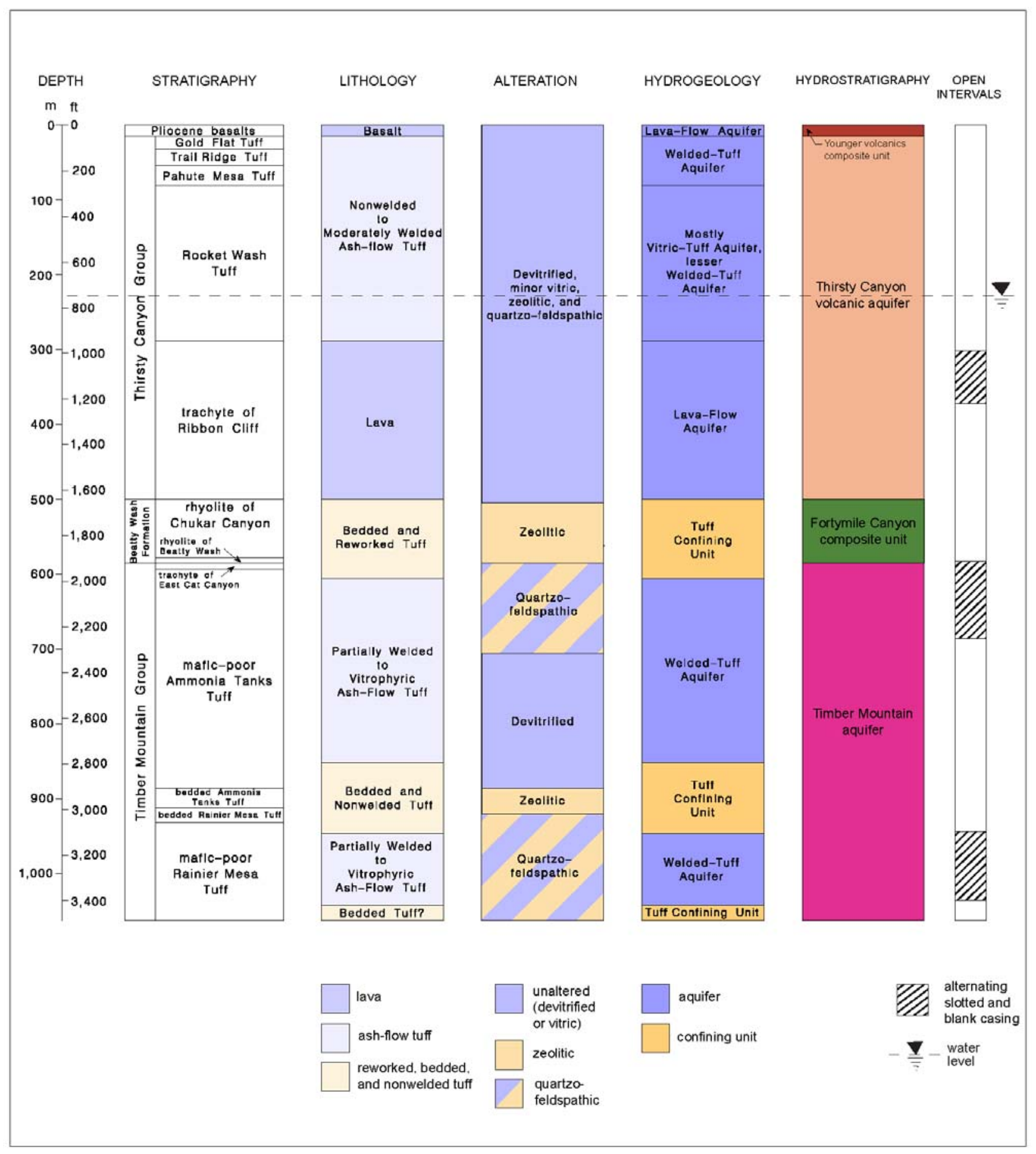

Figure B-24

Graphical Presentation Showing Stratigraphy, Lithology, Alteration, and Hydrogeologic Units for UGTA Well ER-EC-4

(Modified from DOE/NV, 2000c) 


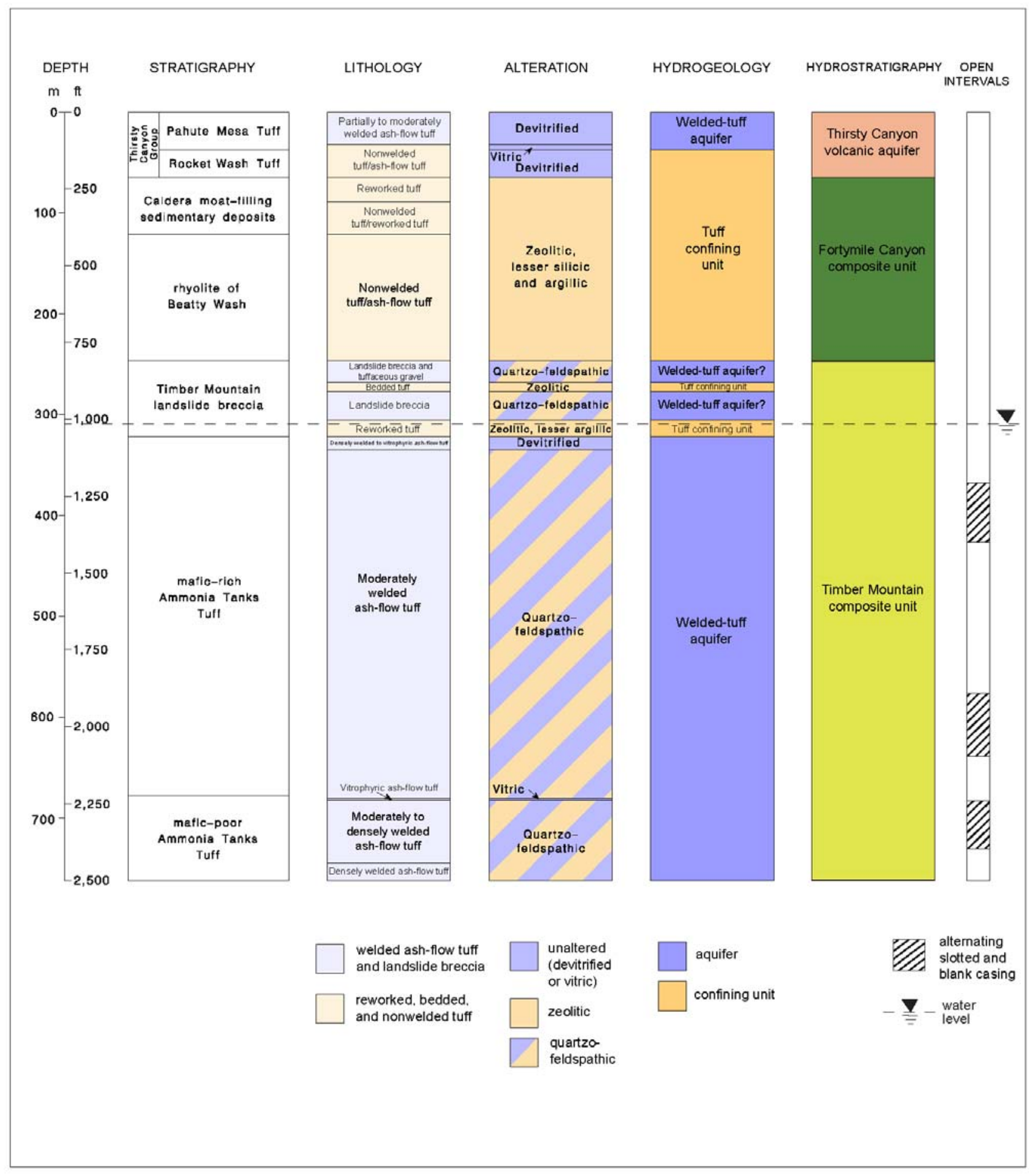

Figure B-25

Graphical Presentation Showing Stratigraphy, Lithology, Alteration, and Hydrogeologic Units for UGTA Well ER-EC-5

(Modified from NNSA/NSO, 2004a) 


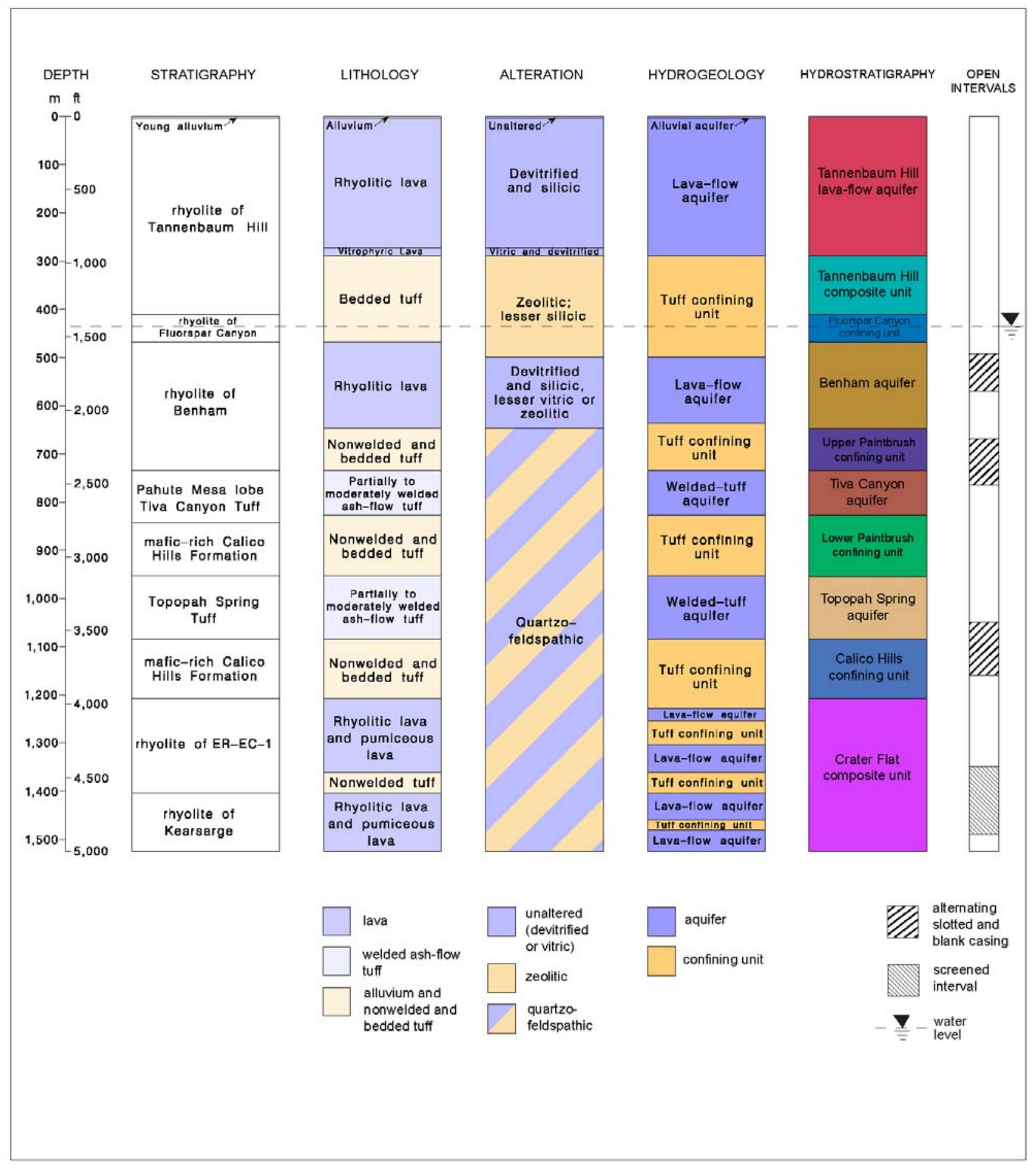

Figure B-26

Graphical Presentation Showing Stratigraphy, Lithology, Alteration, and Hydrogeologic Units for UGTA Well ER-EC-6

(Modified from DOE/NV, 2000a) 


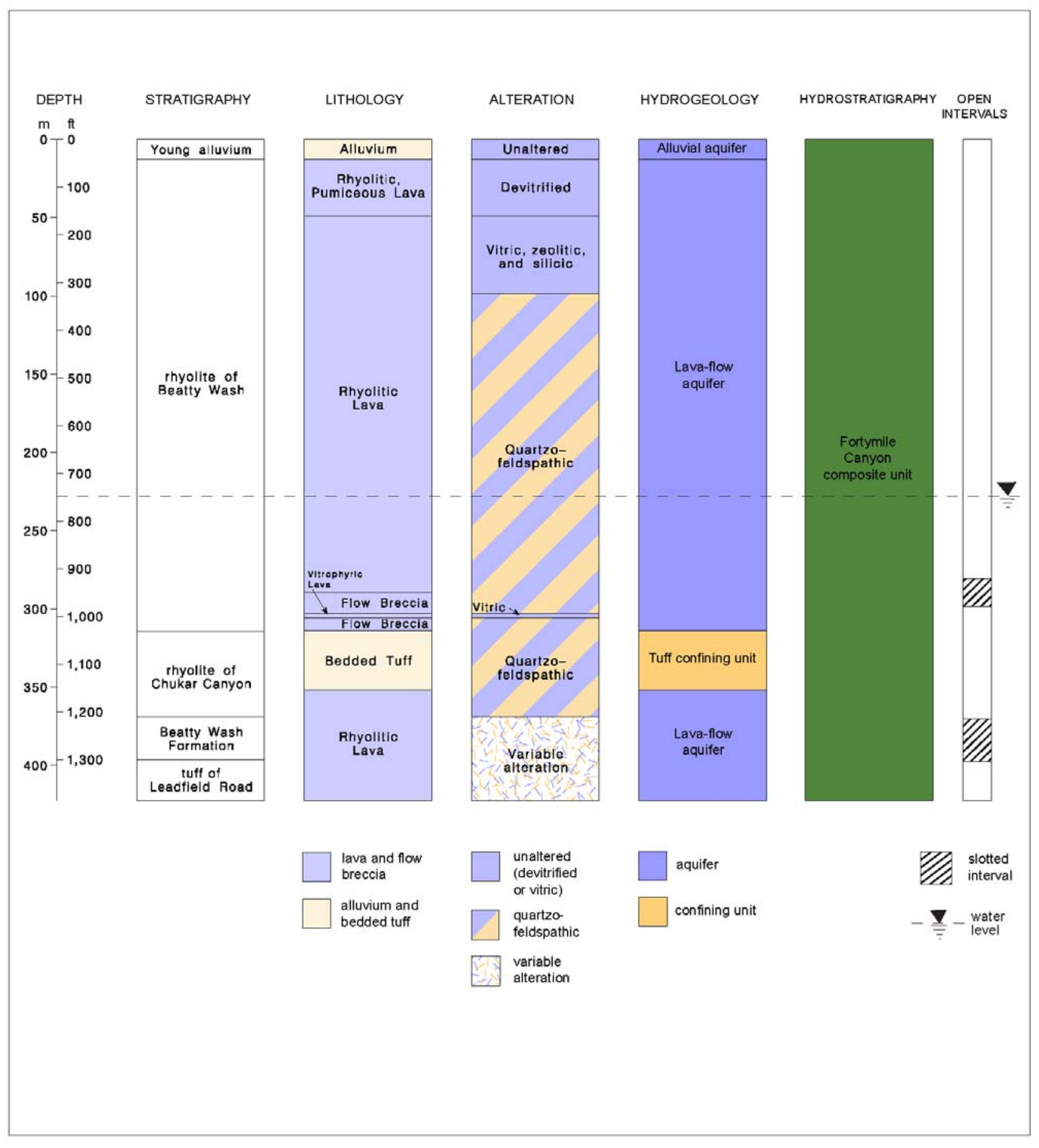

Figure B-27

Graphical Presentation Showing Stratigraphy, Lithology, Alteration, and Hydrogeologic Units for UGTA Well ER-EC-7

(Modified from NNSA/NSO, 2004c) 


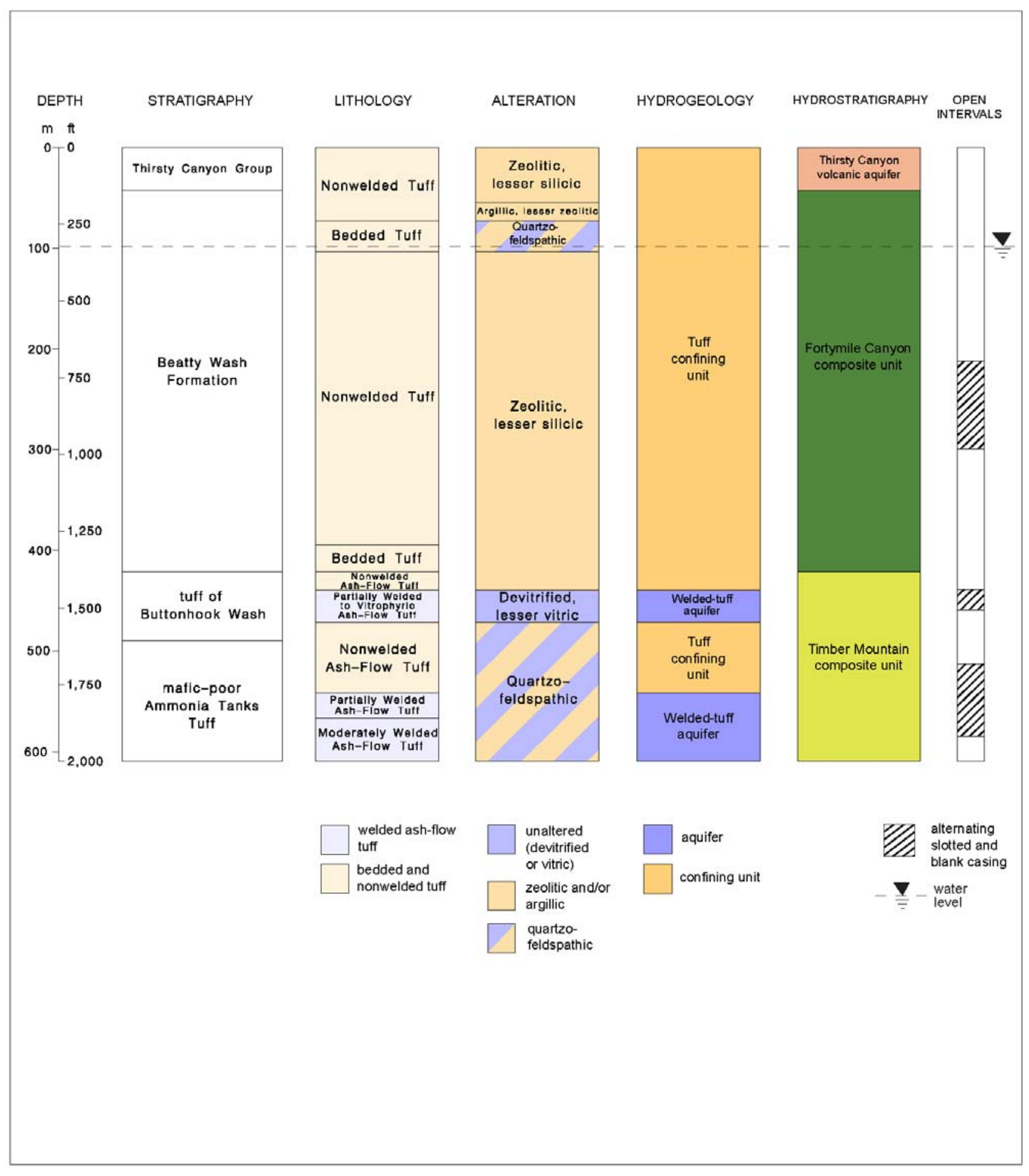

Figure B-28

Graphical Presentation Showing Stratigraphy, Lithology, Alteration, and Hydrogeologic Units for UGTA Well ER-EC-8

(Modified from NNSA/NSO, 2004b) 
Plate 1

Stratigraphic Units of the NTS Region 



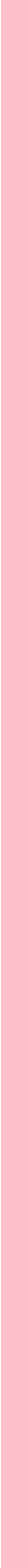




\section{Plate 2}

Correlation of Stratigraphic and Hydrostratigraphic Units for the Four UGTA Hydrostratigraphic Framework Model Areas 

Plate 2
Igraphic Units for UGTA CAU-scale HFMs

Correlation of Hydrostratigraphic Units for UGTA CAU-scale HFMs

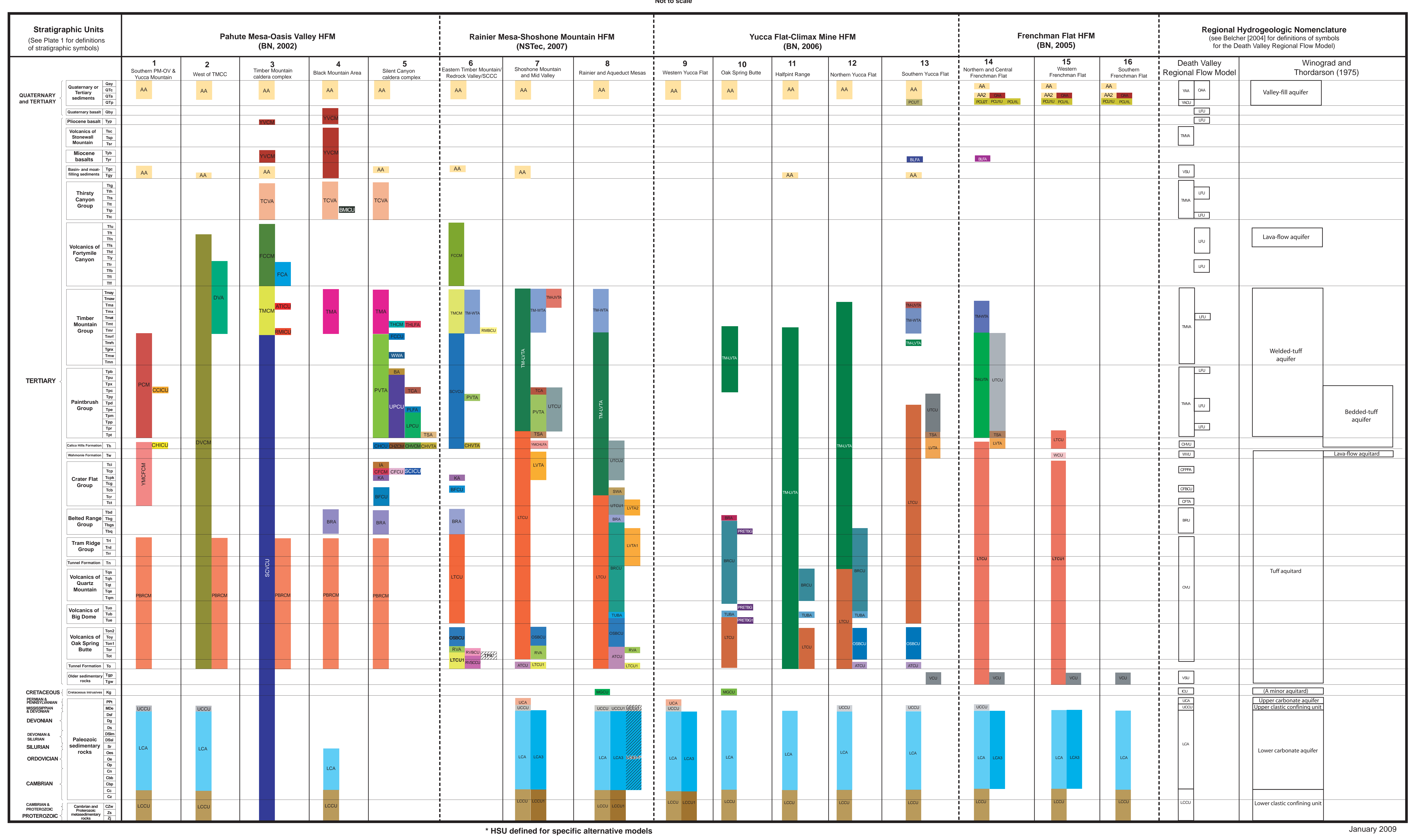




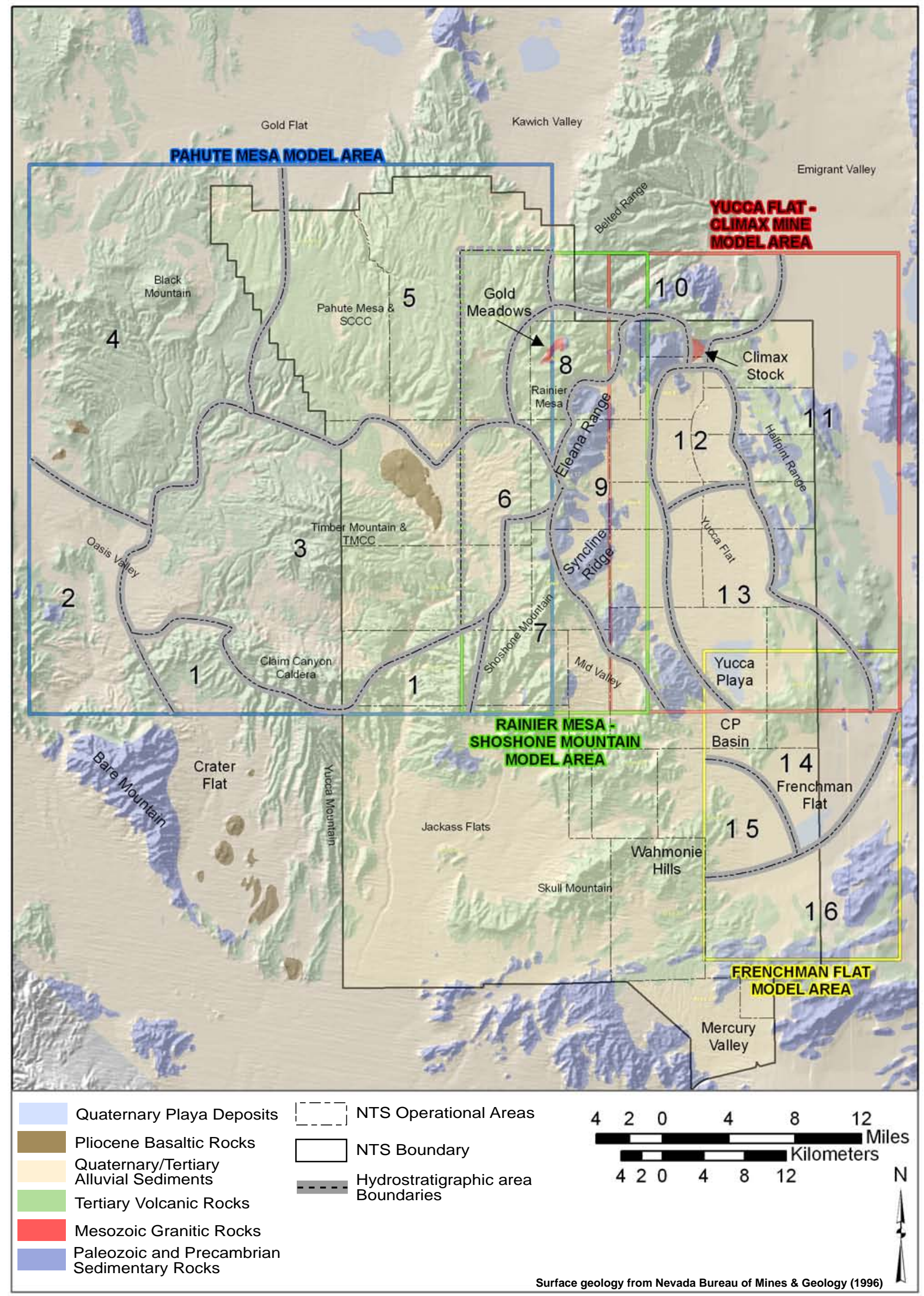

Figure P-1

Generalized Geologic Map Showing the Regions Represented by the Hydostratigraphic Columns in Plate 2 